IGOR AUAD CANO

MODELAGEM E SIMULAÇÃO DINÂMICA DA PASTEURIZAÇÃO CONTÍNUA DE LEITE SUJEITO À INCRUSTAÇÃO

São Paulo

2016 
IGOR AUAD CANO

\section{MODELAGEM E SIMULAÇÃO DINÂMICA DA PASTEURIZAÇÃO CONTÍNUA DE LEITE SUJEITO À INCRUSTAÇÃO}

Dissertação apresentada à Escola Politécnica da Universidade de São Paulo para obtenção do Título de Mestre em Ciências

São Paulo

2016 
IGOR AUAD CANO

\section{MODELAGEM E SIMULAÇÃO DINÂMICA DA PASTEURIZAÇÃO CONTÍNUA DE LEITE SUJEITO À INCRUSTAÇÃO}

Dissertação apresentada à Escola Politécnica da Universidade de São Paulo para obtenção do Título de Mestre em Ciências

Área de Concentração:

Engenharia Química

Orientador:

Prof. Dr. Jorge Andrey Wilhelms Gut

São Paulo

2016 
Este exemplar foi revisado e corrigido em relação à versão original, sob responsabilidade única do autor e com a anuência de seu orientador.

São Paulo, de de

Assinatura do autor:

Assinatura do orientador:

Catalogação-na-publicação

\section{Cano, Igor Auad}

Modelagem e Simulação Dinâmica da Pasteurização Contínua de Leite Sujeito à Incrustação / I. A. Cano -- versão corr. -- São Paulo, 2016. $195 \mathrm{p}$.

Dissertação (Mestrado) - Escola Politécnica da Universidade de São Paulo. Departamento de Engenharia Química.

1.Pasteurização 2.Trocadores de calor 3. Leite 4. Modelagem 5. Simulação I.Universidade de São Paulo. Escola Politécnica. Departamento de Engenharia Química II. t. 
À minha tão amada e respeitada mãe, Ludmilla Auad, por tantos anos de exímia criação, doação e dedicação.

In memoriam ao meu querido irmão, Calipo Auad Cano, o qual sempre me guiou através de seus bons exemplos, carinho incondicional e quebra de paradigmas. 
"Só há um princípio motor: a faculdade de desejar." (Aristóteles) 


\section{AGRADECIMENTOS}

A princípio, agradeço a Deus pelo dom da vida e pelas oportunidades concedidas diariamente.

À minha família, em especial à minha mãe, Ludmilla Auad, a qual sempre me apoiou em todas as decisões, pelo carinho e amor infinitos, particularmente durante 0 mestrado. Muito obrigado pelo bom exemplo, sabedoria e valores ensinados constantemente. Ao meu pai, Pedro Maita Cano, pela ajuda e hombridade ao longo da vida.

Também agradeço enormemente à Bárbara Exposto G. por tantos meses de parceria, paciência, apoio, delicadeza e amizade!

Agradeço veementemente ao Professor Doutor Jorge Andrey Wilhelms Gut por tantos ensinamentos, suporte, paciência e oportunidade de fazer esse trabalho como seu orientado. Muito obrigado por tudo que fez e pela exímia orientação; perfeita.

À Professora Doutora Carmen Cecília Tadini pela dicas, observações e contribuições significativas durante a execução do mestrado.

Ao Professor Doutor Luís de Paiva pela ótima co-orientação e críticas construtivas para manutenção deste trabalho de pesquisa.

À Doutora Carola Gean Carla Cavero Gutierrez, pelo fornecimento e compartilhamento de dados de sua pesquisa e por todas as contribuições ao projeto.

A todos os membros do LEA, entre alunos, professores e funcionários, em especial aos colegas de pesquisa, Tiago Augusto e Eduardo Funcia.

Agradeço ao Conselho Nacional de Desenvolvimento Científico e Tecnológico, CNPq, pela bolsa concedida durante o mestrado, e à Universidade de São Paulo, USP, a qual cedeu toda a sua estrutura física e virtual. 


\section{RESUMO}

A fim de garantir a inocuidade, alguns alimentos industrializados são termicamente tratados por um processo contínuo denominado pasteurização, o qual visa inativar os micro-organismos patogênicos, mantendo, ao mesmo tempo, a sua qualidade sensorial e nutricional. Essa operação é aplicada a produtos como sucos, leite, cervejas, polpas, entre outros. A modelagem matemática deste processo tem como intuito auxiliar no entendimento, controle e posterior otimização desta operação. O principal objetivo deste trabalho foi o desenvolvimento da modelagem do processo contínuo da pasteurização HTST do leite e a validação experimental do modelo empírico da incrustação do produto nas placas do trocador de calor, em malha aberta (sem PID). A modelagem fenomenológica foi composta por balanços diferenciais de energia, para temperatura, e de material, para letalidade, nos canais, nas placas, no tubo de retenção e nas conexões do pasteurizador. Também foi realizada a modelagem empírica da incrustação do leite na seção de aquecimento. Os modelos desenvolvidos representam um conjunto de equações diferenciais ordinárias de primeira e segunda ordem, o qual foi resolvido pelo método das diferenças finitas, pelo uso do software gPROMS. O modelo foi aplicado para representar o comportamento de um pasteurizador a placas de escala laboratorial, com e sem incrustação, com e sem perturbações no sistema e durante a partida do equipamento, através de estudo de caso. Os dados simulados foram apresentados pela distribuição unidimensional e temporal de temperatura e da letalidade do tratamento, ao longo do processo, e do perfil do coeficiente global de troca térmica na seção de aquecimento. Para a validação do modelo de incrustação foi realizado um ensaio experimental da pasteurização de solução proteica (similar ao leite). Inseriu-se termopares em diversos pontos do equipamento e as temperaturas foram registradas ao longo do tempo. As placas do trocador foram pesadas e fotografadas antes e depois do teste para controle da quantidade de material depositado. A partir dos resultados laboratoriais, fez-se 0 ajuste dos parâmetros do modelo de incrustação, simulando novamente. Esses resultados foram comparados aos experimentais, sendo, então, o modelo validado.

Palavras-chave: Incrustação. Letalidade. Trocador de calor a placas. Simulação dinâmica. Modelagem matemática. Tratamento térmico. Leite. Pasteurização. 


\begin{abstract}
In order to guarantee harmlessness, some processed foods are thermally treated in a continuous process named pasteurization, in which the purpose is to eliminate pathogenic microorganisms, while avoiding sensorial and quality losses. This operation is used in products such as juice, beers, milk and dairy food, pulp, and so on. Mathematical modeling of this process seeks to help its understanding, controlling, and optimization. Thus, the aim of this work was to develop and simulate a model of a continuous process pasteurization, and to conduct the experimental validation of a fouling model in the plates of the heat exchanger plates, without a process controller (PID). The phenomenological modeling was composed by differential energy and material balances, for temperature and lethality, respectively, in the channels, plates, holding tube and its connections of the pasteurizer. It was also developed an empirical fouling model for the product in the heating section. All these models represent a set of first and second order differential equations which were solved by a finite difference method through the gPROMS software. This modeling was used to express the behavior of a laboratory scale plate pasteurizer, with and without fouling, with and without system disturbances and during the equipment startup, in a case study. The simulated data was presented by the unidimensional spatial and temporal distribution of temperature and lethality along the process, and overall heat transfer coefficient profile in the heating section. To validate the fouling model, an experimental test by using a protein solution (similar to cow milk) was conducted. The temperature logging over time was done by various thermocouples inserted in the pasteurizer. All the plates were weighed and photographed before and after the tests to quantify the amount of deposits. From laboratory results, fouling model parameters were adjusted and simulation was performed again. These results were compared to the experiments, being the model validated adequately.
\end{abstract}

Keywords: Fouling. Lethality. Plate heat exchanger. Dynamic simulation. Mathematical modeling. Thermal treatment. Milk. Pasteurization. 


\section{LISTA DE FIGURAS}

Figura 3.1 - Diagrama geral de fabricação de leite padronizado integral tipo B...........37

Figura 3.2 - Processo de fabricação de leite pasteurizado padronizado fluido............38

Figura 3.3 - Esquema de um processo de pasteurização com trocadores a placas....41

Figura 3.4 - Alguns modelos de PHEs industriais comerciais .................................45

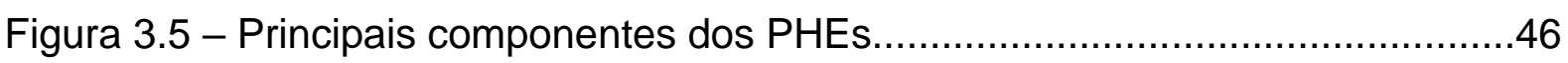

Figura 3.6 - Esquema do escoamento e troca de calor nas placas do PHE................47

Figura 3.7 - Placa de um PHE incrustado após processamento de leite bovino.........50

Figura 3.8 - Esquema de incrustação da proteína $\beta$-lactoglobulina sobre a placa......51

Figura 4.1 - Visão global do processo de pasteurização e seus pontos de registro de

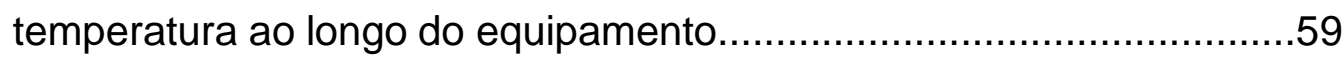

Figura 4.2 - Dimensões de uma típica placa chevron de PHE....................................61

Figura 4.3 - Volume de controle $(V C)$ para balanço de energia em canal genérico do PHE.

Figura 4.4 - Parâmetro de configuração do PHE genérico em relação a localização dos fluidos quente e frio.

Figura 4.5 - Volume de controle para balanço de energia em placa genérica do PHE. .71

Figura 4.6 - Distribuição da temperatura da água, placa, depósito e leite em uma parte qualquer do PHE na seção de aquecimento do equipamento .78

Figura 4.7 - Curvas típicas do fator de incrustação em função do tempo de processo .79

Figura 4.8 - Volume de controle $(V C)$ para balanço de energia diferencial no tubo de retenção e em seus trechos. 81

Figura 4.9 - Exemplo de arranjo em série de um PHE com 12 canais e 13 placas......86 Figura 5.1 - Pasteurizador laboratorial FT-43 (Armfield, UK) empregado no estudo de caso. .89

Figura 5.2 - Dimensões em milímetros da gaxeta do PHE 92

Figura 5.3 - Sistema de aquisição de temperatura do processo ao longo do funcionamento do pasteurizador durante os ensaios experimentais....106

Figura 5.4 - Identificação das placas dos PHEs e inserção dos termopares. 110 
Figura 6.1 - Histórico de temperatura (do leite e da água de processo) ao longo do tempo de processo da simulação da partida do pasteurizador

Figura 6.2 - Distribuição da letalidade ao tratamento térmico simulado ao longo do tempo durante a partida pasteurizador com água e leite cru.

Figura 6.3 - Distribuição da letalidade ao tratamento térmico simulado ao longo do tempo durante partida pasteurizador apenas com leite cru

Figura 6.4 - Evolução dos perfis de temperatura do leite ao longo do tempo espacial durante a partida do pasteurizador em diferentes instantes de processo

Figura 6.5 - Evolução dos perfis de letalidade ao longo do tempo espacial durante a partida do pasteurizador em diferentes instantes de processo

Figura 6.6 - Histórico de temperatura e distribuição da letalidade para $C$. burnetii em relação ao tempo espacial do processo de pasteurização do leite

Figura 6.7 - Distribuição de temperatura (curvas) e da concentração média de $C$. burnetti nos canais ímpares (pontos) da seção de aquecimento na simulação da pasteurização em estado estacionário

Figura 6.8 - Distribuição de temperatura ao longo do espaço adimensionalizado em todas as placas da seção de aquecimento na simulação em estado estacionário. 125

Figura 6.9 - Distribuição de temperatura média em todas as placas da seção de aquecimento na simulação da pasteurização em estado estacionário. 126

Figura 6.10 - Distribuição de temperatura do leite em relação ao tempo espacial, em quatro diferentes vazões da utilidade de aquecimento, durante a pasteurização.

Figura 6.11 - Distribuições da letalidade simulada em relação ao tempo espacial, em quatro diferentes vazões da utilidade de aquecimento, durante a pasteurização 130

Figura 6.12 - Distribuição do logaritmo da concentração microbiana ao longo do tempo quando o sistema sofreu perturbações na concentração inicial de $C$. burnetii no leite

Figura 6.13 - Distribuição do Log da concentração microbiana ao longo do tempo espacial para três concentrações iniciais de $C$. burnetii no leite cru.....133 
Figura 6.14 - Histórico de temperatura do leite ao longo do tempo de processo da simulação das perturbações na temperatura de entrada da utilidade de aquecimento

Figura 6.15 - Detalhamento dos degraus no histórico de temperatura do leite em T3, T4, T5 e T6 da simulação das perturbações na temperatura de água de aquecimento. 135

Figura 6.16 - Distribuição da letalidade simulada ao longo do tempo da simulação das perturbações na temperatura de entrada da utilidade de aquecimento 136

Figura 6.17 - Detalhamento dos degraus da distribuição da letalidade em L6, L5, L4 e L3 da simulação das perturbações na temperatura de entrada da utilidade de aquecimento entre os instantes $t=50 \mathrm{~s}$ e $t=600 \mathrm{~s}$ 137

Figura 6.18 - Histórico de temperatura do leite ao longo do tempo de processo da simulação da perturbação na temperatura de entrada do leite cru 138

Figura 6.19 - Distribuição da letalidade ao tratamento térmico simulado ao longo do tempo da simulação das perturbações na temperatura de entrada do leite cru

Figura 6.20 - Histórico de temperatura do leite ao longo do tempo de processo da simulação das perturbações na vazão da utilidade de aquecimento...140

Figura 6.21 - Distribuição da letalidade ao tratamento térmico simulado ao longo do tempo da simulação das perturbações na vazão da utilidade de aquecimento

Figura 6.22 - Detalhamento dos degraus no histórico de temperatura do leite em T3, T4, T5 e T6 da simulação das perturbações na vazão da utilidade de aquecimento 142

Figura 6.23 - Detalhamento dos degraus da distribuição da letalidade em L6, L5, L4 e L3 da simulação das perturbações na vazão de entrada da utilidade de aquecimento 143

Figura 6.24 - Histórico de temperatura do leite ao longo do processo da simulação das perturbações na vazão e na temperatura da utilidade de aquecimento e na temperatura de entrada do leite cru ao mesmo tempo.

Figura 6.25 - Distribuição da letalidade ao tratamento térmico simulado ao longo do tempo da simulação das perturbações na vazão e temperatura da 
utilidade de aquecimento e na temperatura de entrada do leite cru ao mesmo tempo

Figura 6.26 - Distribuição da concentração microbiana $(\mathrm{UFC} / \mathrm{mL})$ da $C$. burnetii ao longo tempo e do espaço adimensionalizado, no canal 11 da seção de aquecimento, quando o sistema sofreu perturbações na vazão e temperatura da utilidade de aquecimento e na temperatura de entrada do leite cru ao mesmo tempo 146

Figura 6.27 - Distribuição do fator de incrustação $\left(R_{f}\right)$ e do coeficiente global de transferência de calor total $\left(U_{t}\right)$, na seção de aquecimento, durante a pasteurização do leite sujeita à incrustação 147

Figura 6.28 - Histórico de temperatura do leite ao longo do tempo de processo da simulação da pasteurização do leite sujeita à incrustação 149

Figura 6.29 - Histórico de temperatura do leite (T3, T4 e T5) da simulação da pasteurização do leite sujeita à incrustação entre $o$ instante $t=0 \mathrm{~s}$ e $t=$ $12000 \mathrm{~s}$ 150

Figura 6.30 - Histórico de temperatura de entrada (T9) e de saída (T10) da utilidade quente na simulação da pasteurização do leite sujeita à incrustação entre os instantes $t=0 \mathrm{~s}$ e $t=12000 \mathrm{~s}$ 151

Figura 6.31 - Histórico da letalidade ao tratamento térmico simulado, ao longo do tempo, da simulação da pasteurização do leite sujeita à incrustação..152

Figura 6.32 - Distribuição da concentração microbiana (UFC/mL) da C. burnetii ao longo tempo e do espaço adimensionalizado, no canal 11 da seção de aquecimento, durante a pasteurização de leite sujeito à incrustação...153

Figura 6.33 - Placas 8 e 9 da seção de aquecimento do PHE do pasteurizador logo após o processamento da solução proteica 155

Figura 6.34 - Quantidade de material seco depositado nas placas da seção de aquecimento após ensaio experimental. 156

Figura 6.35 - Comparação entre os valores experimentais (teste 2) e os teóricos para massa total depositada nas placas da seção de aquecimento do equipamento 157

Figura 6.36 - Perfis de temperatura simulada (curvas) e experimental (pontos) das utilidades de aquecimento e resfriamento na seção de aquecimento do equipamento 
Figura 6.37 - Perfis de temperatura simulada e experimental (teste 2) da solução representativa ao leite na seção de aquecimento do equipamento 162

Figura 6.38 - Perfis de temperatura experimental da solução proteica na saída da seção de aquecimento e do tubo de retenção, respectivamente, durante o teste 2 163

Figura 6.39 - Comparação entre os valores experimentais (pontos discretos) e os simulados (linha contínua) para taxa de energia térmica da solução no aquecimento .164

Figura 6.40 - Comparação entre os valores experimentais (pontos discretos) e os simulados (linha contínua) para o fator de incrustação do produto no aquecimento .165

Figura 6.41 - Comparação entre os valores experimentais (pontos discretos) e os simulados (linha contínua) para o coeficiente global de transferência de calor na seção de aquecimento entre o produto e a utilidade 166

Figura 6.42 - Formação de bolhas de ar nos tubos e conexões do equipamento durante a pasteurização da solução láctea para a validação experimental. 168 


\section{LISTA DE TABELAS}

Tabela 3.1 - Composição química média do leite bovino fluido...............................32

Tabela 3.2 - Composição lipídica média do leite bovino integral (3,2\% de gordura) ...33

Tabela 3.3 - Principais vitaminas presentes no leite bovino fluido cru......................33

Tabela 3.4 - Concentração das principais proteínas do leite bovino.........................34

Tabela 3.5 - Previsão populacional microbiana (UFC/mL) no leite bovino cru...........36

Tabela 3.6 - Principais tipos de tratamento térmico da indústria.............................41

Tabela 5.1 - Dimensões do tubo de retenção e suas conexões..............................91

Tabela 5.2 - Características das placas do pasteurizador Armfield FT-43A..............91

Tabela 5.3 - Parâmetros da configuração das 3 seções do PHE estudado.................92

Tabela 5.4 - Coeficientes globais de troca térmica entre fluido e o ar para o tubo de retenção e suas conexões.......................................................93

Tabela 5.5 - Valores calculados de tempo espacial para leite ao longo no processo..94

Tabela 5.6 - Parâmetros cinéticos relativos a inativação térmica da $C$. burnetii.........94

Tabela 5.7 - Parâmetros utilizados na simulação de partida do pasteurizador...........98

Tabela 5.8 - Parâmetros das simulações com perturbações na vazão de água

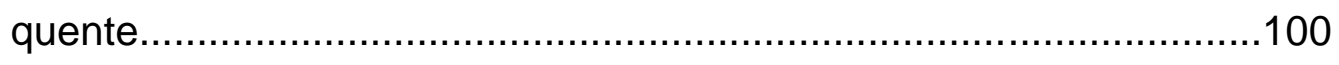

Tabela 5.9 - Parâmetros da simulação com perturbações na temp. de água

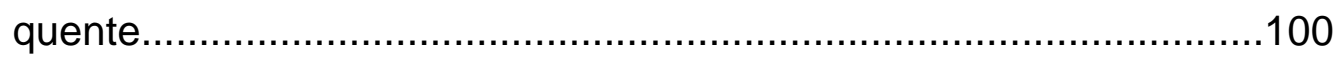

Tabela 5.10 - Parâmetros da simulação com perturbações na temp. do leite

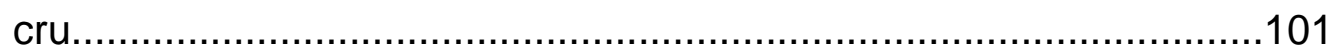

Tabela 5.11 - Parâmetros da simulação com perturbações na concentração microbiana da bactéria C. burnetti no leite cru.................................101

Tabela 5.12 - Parâmetros utilizados na simulação do processo estacionário...........102

Tabela 5.13 - Parâmetros das simulações para comparação entre 4 diferentes vazões da utilidade de aquecimento. 102

Tabela 5.14 - Parâmetros da simulação com perturbações na vazão da utilidade de aquecimento e na temperatura do leite e da água de aquecimento......103

Tabela 5.15 - Componentes usados nos ensaios de validação da incrustação........108

Tabela 5.16 - Parâmetros operacionais dos ensaios de validação da incrustação...109 
Tabela 6.1 - Intervalos calculados para algumas das variáveis e parâmetros da modelagem para o leite bovino na vazão nominal, em estado estacionário, nos PHEs..................................................................127

Tabela 6.2 - Intervalos calculados para algumas das variáveis e parâmetros da modelagem para a utilidade quente na vazão nominal, em estado estacionário, nos PHEs. 127

Tabela 6.3 - Parâmetros do modelo empírico da incrustação antes e após o

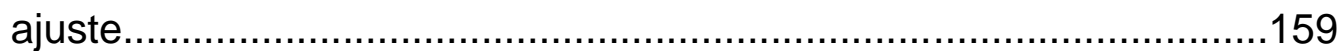




\section{LISTA DE ABREVIATURAS E SIGLAS}

ANVISA Agência Nacional de Vigilância Sanitária

BFDM Backward Finite Difference Method (Método de Diferenças

Finitas para Trás)

CFD Computacional Fluid Dynamic (Dinâmica dos Fluidos

Computacional)

CFDM Centered Finite Difference Method (Método de Diferenças Finitas Centradas)

CIP Cleaning-in-place (Limpeza no local)

FAO Food and Agriculture Organization (Organização das Nações Unidas para a Alimentação e a Agricultura)

FDA Food and Drug Administration (Administração de Alimentos e Remédios)

FFDM Forward Finite Difference Method (Método de Diferenças Finitas para Frente)

HTST High Temperature Short Time (Alta Temperatura Curto Tempo)

LTLT Low Temperature Long Time (Baixa Temperatura Curto Tempo)

MAPA Ministério da Agricultura, Pecuária e Abastecimento

NMP Número mais provável

PI Ponto isoelétrico

PHE Plate Heat Exchanger (Trocador de calor a placas)

UHT Ultra High Temperature (Ultra Alta Temperatura)

UFC Unidades formadoras de colônia

VC Volume de controle 


\section{LISTA DE SÍMBOLOS}

\begin{tabular}{lll}
$a_{i}$ & Parâmetro da equação de Nusselt $(i=1,2,3)$ & Adimensional \\
$A_{c}$ & Área da seção transversal ao escoamento & $\mathrm{m}^{2}$ \\
$A_{P}$ & Área de troca térmica desenvolvida de uma placa & $\mathrm{m}^{2}$ \\
$A_{T}$ & Área de troca térmica do tubo & $\mathrm{m}^{2}$ \\
$A_{d}$ & Área desenvolvida & $\mathrm{m}^{2}$ \\
$A_{t p}$ & Área da secção transversal da placa & $\mathrm{m}^{2}$ \\
$A$ & Área genérica & $\mathrm{m}^{2}$ \\
$b$ & Espessura do canal, distância entre duas placas & $\mathrm{m}$ \\
$C_{A, i}$ & Concentração da espécie A nos canais e tubos & $\mathrm{UFC} / \mathrm{mL}$ \\
$C_{A, 0}$ & Concentração da espécie A no tempo inicial & $\mathrm{UFC} / \mathrm{mL}$ \\
$C_{A}$ & Concentração da espécie A & $\mathrm{UFC} / \mathrm{mL}$ \\
$C p_{i}$ & Calor específico do fluido localizado no canal $i$ & $\mathrm{~J} / \mathrm{kg} \cdot \mathrm{K}$ \\
$C p_{p}$ & Calor específico da placa & $\mathrm{J} / \mathrm{kg} \cdot \mathrm{K}$ \\
$C p$ & Calor específico & $\mathrm{J} / \mathrm{kg} \cdot \mathrm{K}$ \\
$d$ & Diâmetro interno & $\mathrm{m}$ \\
$D$ & Tempo de redução decimal & $\mathrm{s}$ \\
$D_{e}$ & Diâmetro equivalente & $\mathrm{m}$ \\
$D_{h}$ & Diâmetro hidráulico & $\mathrm{m}$ \\
$D_{P}$ & Diâmetro do orifício & $\mathrm{m}$ \\
$D_{r e f}$ & Tempo de redução decimal a uma $T_{r e f}$ & $\mathrm{~s}$ \\
$d U$ & Diferencial de energia interna & $\mathrm{J}$ \\
$e_{P}$ & Espessura da placa metálica & $\mathrm{m}$ \\
$e_{f}$ & Espessura da camada de material incrustrado & $\mathrm{m}$ \\
$E$ & Energia & $\mathrm{J}$ \\
$E_{C}$ & Energia cinética & $\mathrm{J}$ \\
$E_{P}$ & Energia potencial & $\mathrm{J}$ \\
$F$ & Parâmetro cinético de destruição microbiológico & $\mathrm{s}$ \\
$G$ & Fluxo mássico & $\mathrm{kg} / \mathrm{s} . \mathrm{m}^{2}$ \\
$h$ & Coeficiente convectivo de troca térmica & $\mathrm{W} / \mathrm{m}^{2} . \mathrm{K}$ \\
& & \\
\hline & &
\end{tabular}




\begin{tabular}{|c|c|c|}
\hline$H$ & Entalpia & $\mathrm{J}$ \\
\hline $\bar{H}$ & Entalpia específica & $\mathrm{J} / \mathrm{mol}$ ou $\mathrm{J} / \mathrm{kg}$ \\
\hline$i$ & Contador genérico & Adimensional \\
\hline$j$ & Contador genérico & Adimensional \\
\hline$J_{P}$ & Variável auxiliar da modelagem das placas & $\mathrm{s}$ \\
\hline$k$ & Condutividade térmica & $\mathrm{W} / \mathrm{m} \cdot \mathrm{K}$ \\
\hline$k_{A}$ & Constante cinética da reação química & $1 / s$ \\
\hline$k_{P}$ & Condutividade térmica da placa & $\mathrm{W} / \mathrm{m} \cdot \mathrm{K}$ \\
\hline$k_{f}$ & Condutividade térmica do material incrustrado & $\mathrm{W} / \mathrm{m} \cdot \mathrm{K}$ \\
\hline$L$ & Comprimento útil da placa & $\mathrm{m}$ \\
\hline$L_{t}$ & Comprimento do tubo & $\mathrm{m}$ \\
\hline$L_{P}$ & Comprimento da placa entre os dois orifícios & $\mathrm{m}$ \\
\hline$\dot{m}$ & Vazão mássica & $\mathrm{kg} / \mathrm{s}$ \\
\hline$\dot{m}_{i}$ & Vazão mássica no canal $i$ & $\mathrm{~kg} / \mathrm{s}$ \\
\hline$m_{f}$ & Massa incrustada nas placas do PHE & $g$ \\
\hline$\dot{m}^{I}$ e $\dot{m}^{I I}$ & Vazão mássica do fluido dos lados I ou II do PHE & $\mathrm{kg} / \mathrm{s}$ \\
\hline$N$ & Número de canais por passe & Adimensional \\
\hline$N^{I}$ e $N^{I}$ & Número de passagens no lado I ou II do trocador & Adimensional \\
\hline$N c$ & Número total de canais & Adimensional \\
\hline$N_{P}$ & Número total de placas térmicas do pacote & Adimensional \\
\hline$N u$ & Número de Nusselt & Adimensional \\
\hline$\dot{n}_{e, A}$ & Taxa material de A na entrada no $V C$ & UFC/s \\
\hline$\dot{n}_{s, A}$ & Taxa material de A na saída do $V C$ & UFC/s \\
\hline$P$ & Número de passes da seção & Adimensional \\
\hline$P^{I}$ e $P^{I I}$ & Número de passes nos lados I ou II do PHE & Adimensional \\
\hline $\operatorname{Pr}$ & Número de Prandtl & Adimensional \\
\hline$P_{w}$ & Perímetro molhado do escoamento & $\mathrm{m}$ \\
\hline$\dot{Q}$ & Taxa de calor & W \\
\hline$\dot{q}$ & Fluxo de calor & $\mathrm{W} / \mathrm{m}^{2}$ \\
\hline$r_{A}$ & Velocidade de reação química & $\mathrm{mol} / \mathrm{L} . \mathrm{s}$ \\
\hline$R e$ & Número de Reynolds & Adimensional \\
\hline$\dot{R}_{G, A}$ & Taxa de geração química do elemento $A$ & $\mathrm{~mol} / \mathrm{s}$ \\
\hline
\end{tabular}




\begin{tabular}{|c|c|c|}
\hline$\dot{R}_{C, A}$ & Taxa de consumo química do elemento $A$ & $\mathrm{~mol} / \mathrm{s}$ \\
\hline$R_{t}$ & Resistência térmica total & $\mathrm{m}^{2} . \mathrm{K} / \mathrm{W}$ \\
\hline$R_{k}$ & Resistência térmica convectiva & $\mathrm{m}^{2} . \mathrm{K} / \mathrm{W}$ \\
\hline$R_{h}$ & Resistência térmica condutiva & $\mathrm{m}^{2} . \mathrm{K} / \mathrm{W}$ \\
\hline$R_{f}$ & Fator de incrustação (fouling) & $\mathrm{m}^{2} \cdot \mathrm{K} / \mathrm{W}$ \\
\hline$R_{\max }$ & Fator de incrustação máximo (fouling) & $\mathrm{m}^{2} \cdot \mathrm{K} / \mathrm{W}$ \\
\hline$R$ & Raio do tubo & $\mathrm{m}$ \\
\hline$S V$ & Valor de esterilização & Adimensional \\
\hline$S_{i}$ & Variável binária de sentido de escoamento no canal $i$ & -1 ou +1 \\
\hline$t_{m}$ & Tempo médio de residência & $\mathrm{s}$ \\
\hline$t$ & Tempo & $\mathrm{s}$ \\
\hline$t_{f}$ & Tempo de incrustação do processo & $\mathrm{s}$ \\
\hline$t_{f o}$ & Período de indução da incrustação & $\mathrm{s}$ \\
\hline$T$ & Temperatura & $\mathrm{K}$ \\
\hline$T_{\text {ref }}$ & Temperatura de referência para o processo térmico & $\mathrm{K}$ \\
\hline$T_{\infty}$ & Temperatura ambiente & $\mathrm{K}$ \\
\hline$T_{f}$ & Temperatura da camada incrustada & $\mathrm{K}$ \\
\hline$T_{T}$ & Temperatura do tubo & $\mathrm{K}$ \\
\hline$T_{P}$ & Temperatura da placa do PHE & $\mathrm{K}$ \\
\hline$T_{i}$ & Temperatura do canal genérico $i$ & $\mathrm{~K}$ \\
\hline$\nabla T$ & Gradiente de temperatura & $\mathrm{K}$ \\
\hline$U$ & Coeficiente global de troca térmica do trocador & $\mathrm{W} / \mathrm{m}^{2} . \mathrm{K}$ \\
\hline$U_{t}$ & Coeficiente global de troca total nos canais do PHE & $\mathrm{W} / \mathrm{m}^{2} . \mathrm{K}$ \\
\hline$U_{T}$ & Coeficiente global de troca térmica nos tubos & $\mathrm{W} / \mathrm{m}^{2} . \mathrm{K}$ \\
\hline $\bar{v}$ & Velocidade média de escoamento & $\mathrm{m} / \mathrm{s}$ \\
\hline $\bar{v}_{i}$ & Velocidade média de escoamento no canal $i$ & $\mathrm{~m} / \mathrm{s}$ \\
\hline$v_{T}$ & Velocidade média de escoamento nos tubos & $\mathrm{m} / \mathrm{s}$ \\
\hline$V$ & Volume & $\mathrm{m}^{3}$ \\
\hline$V_{p}$ & Volume da placa & $m^{3}$ \\
\hline$V_{T}$ & Volume interno do tubo & $\mathrm{m}^{3}$ \\
\hline$\dot{V}$ & Vazão volumétrica & $\mathrm{m}^{3} / \mathrm{s}$ \\
\hline$w$ & Largura do canal entre as gaxetas & $\mathrm{m}$ \\
\hline
\end{tabular}




\begin{tabular}{|c|c|c|}
\hline$x$ & Direção tangencial ao escoamento nos canais & $\mathrm{m}$ \\
\hline$x_{w}$ & Fração mássica de água do leite & Adimensional \\
\hline$x_{L}$ & Fração mássica de lipídeos do leite & Adimensional \\
\hline$Y_{f}$ & Parâmetro binário para o tipo de fluxo no canal & 0 ou 1 \\
\hline$Y_{h}$ & $\begin{array}{l}\text { Parâmetro binário, associa os fluidos aos lados do } \\
\text { PHE }\end{array}$ & 0 ou 1 \\
\hline & Variação de $T$ para redução do valor de $D$ em $90 \%$ & ${ }^{\circ} \mathrm{C}$ \\
\hline
\end{tabular}

\section{Símbolos Gregos}

\begin{tabular}{|c|c|c|}
\hline$\alpha_{i}$ & Coeficiente do modelo térmico num canal $i$ & $\mathrm{~m}^{2} . \mathrm{K} / \mathrm{W}$ \\
\hline$\alpha^{I}$ & Coeficiente do modelo térmico para o lado I & $\mathrm{m}^{2} . \mathrm{K} / \mathrm{W}$ \\
\hline$\alpha^{\mathrm{II}}$ & Coeficiente do modelo térmico para o lado II & $\mathrm{m}^{2} . \mathrm{K} / \mathrm{W}$ \\
\hline$\alpha_{P}$ & Difusividade térmica da placa & $\mathrm{m}^{2} / \mathrm{s}$ \\
\hline$\alpha_{\mathrm{t}}$ & Difusividade térmica do fluido & $\mathrm{m}^{2} / \mathrm{s}$ \\
\hline$\alpha_{\mathrm{f}}$ & Parâmetro empírico de tendência da incrustação & $\mathrm{s}$ \\
\hline$\varpi$ & Coeficiente do modelo térmico da placa & $\mathrm{m}^{2} . \mathrm{K} / \mathrm{W}$ \\
\hline$\beta$ & Ângulo de inclinação das ranhuras chevron & $\circ$ \\
\hline$\Delta T_{l m}$ & Média logarítmica das diferenças de temperatura & ${ }^{\circ} \mathrm{C}$ \\
\hline$\eta_{\mathrm{i}}$ & $\begin{array}{l}\text { Direção tangencial ao escoamento (axial) na parte } \\
\text { interna do canal ou no dos tubos }\end{array}$ & Adimensional \\
\hline$\mu$ & Viscosidade do fluido & Pa.s \\
\hline$\mu_{\mathrm{w}}$ & Viscosidade do fluido na temperatura da parede & Pa.s \\
\hline$\pi$ & Constante pi $(\pi=3,1416 \ldots)$ & Adimensional \\
\hline$\rho_{\mathrm{i}}$ & Densidade do fluido num canal $i$ & $\mathrm{~kg} / \mathrm{m}^{3}$ \\
\hline$\rho$ & Densidade do fluido & $\mathrm{kg} / \mathrm{m}^{3}$ \\
\hline$\rho_{\mathrm{P}}$ & Densidade do material da placa & $\mathrm{kg} / \mathrm{m}^{3}$ \\
\hline$\rho_{f}$ & Densidade do material incrustado nas placas & $\mathrm{kg} / \mathrm{m}^{3}$ \\
\hline$\tau_{\mathrm{i}}$ & Tempo espacial do fluido no canal $i$ & $\mathrm{~S}$ \\
\hline$\tau_{\mathrm{T}}$ & Tempo espacial do fluido no tubo & s \\
\hline
\end{tabular}




\begin{tabular}{|c|c|c|}
\hline$\tau_{s}$ & Tempo espacial do produto na seção em questão & $\mathrm{S}$ \\
\hline$v$ & Viscosidade cinemática & $\mathrm{m}^{2} / \mathrm{s}$ \\
\hline$\varnothing$ & $\begin{array}{l}\text { Parâmetro que define a posição da conexão de } \\
\text { alimentação do } \operatorname{PHE}(\emptyset=1,2,3 \text { ou } 4)\end{array}$ & Adimensional \\
\hline$\Phi$ & Fator de alagamento da placa & Adimensional \\
\hline$\gamma$ & Parâmetro auxiliar da modelagem no tubo & Adimensional \\
\hline
\end{tabular}

\section{Subscritos}

$\begin{array}{ll}\text { cold } & \text { Fluido frio ou de resfriamento } \\ \text { hot } & \text { Fluido quente ou de aquecimento } \\ c & \text { Cold (do inglês frio) } \\ h & \text { Hot (do inglês quente) } \\ i & \text { Elemento genérico } i \\ e n t & \text { Entrada } \\ \text { sai } & \text { Saída } \\ A & \text { Elemento alvo (bactéria, enzima ou nutriente) } \\ V C & \text { Volume de controle }\end{array}$

\section{Sobrescritos}

I Lado $I$ do trocador (conjunto de canais ímpares)

II Lado II do trocador (conjunto dos canais pares) 


\section{SUMÁRIO}

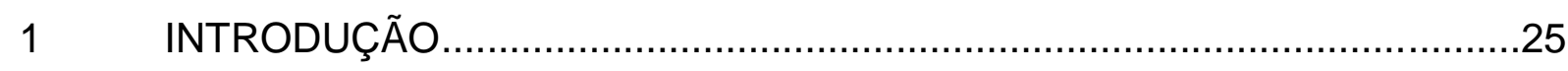

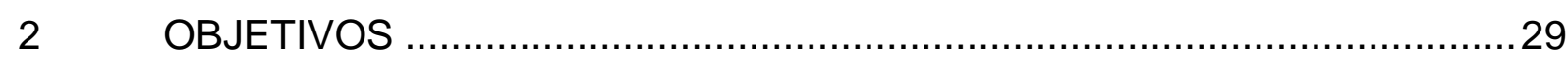

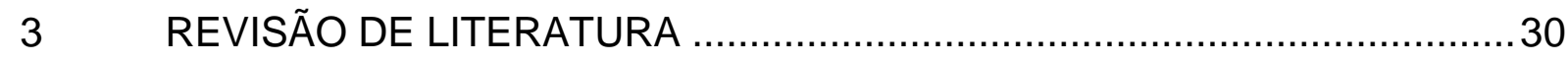

3.1 Mercado de Leite Bovino ........................................................................

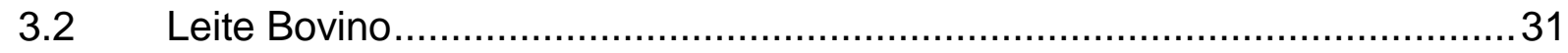

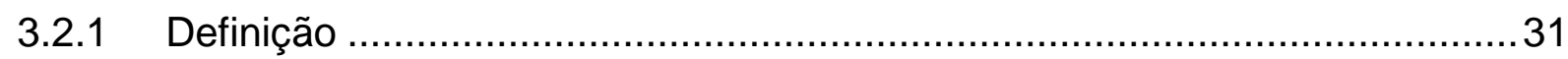

3.2.2 Composição Química e Nutricional ...........................................................31

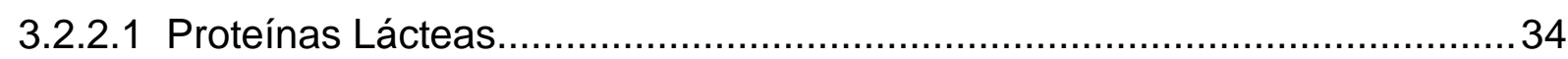

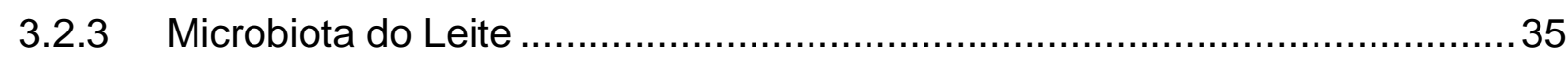

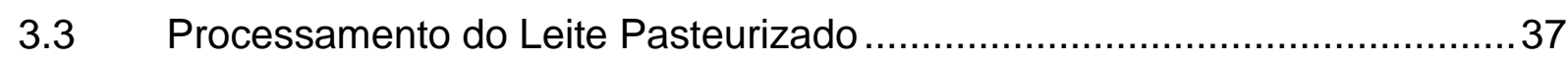

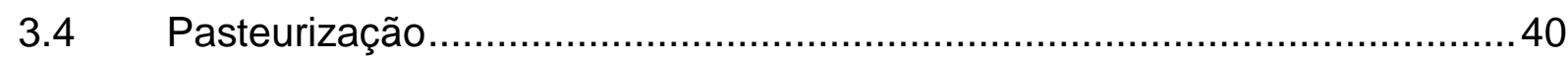

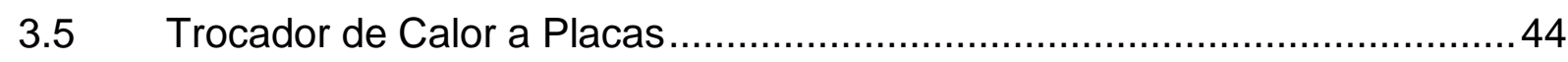

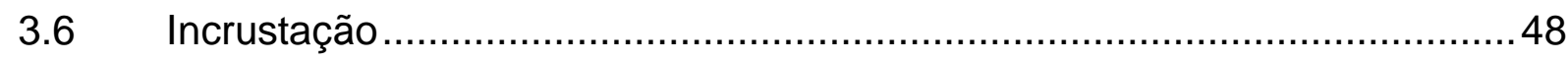

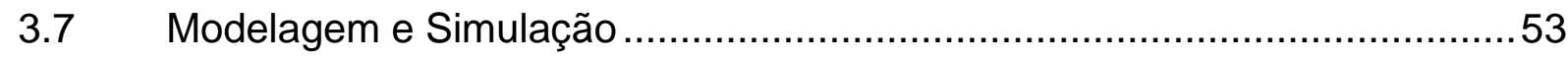

4 MODELAGEM MATEMÁTICA DA PASTEURIZAÇÃO …..........................58

4.1 Modelagem Matemática do Trocador de Calor a Placas................................63

4.1.1 Balanço de Massa para o Fluido nos Canais .............................................63

4.1.2 Balanço de Energia para o Fluido nos Canais ............................................ 64

4.1.3 Balanço de Energia para as Placas ...........................................................

4.1.4 Modelagem da Letalidade nos Canais do PHE ......................................74

4.1.5 Modelagem da Incrustação nos Canais ................................................. 77

4.2 Modelagem do Tubo de Retenção e suas Conexões................................... 80

4.2.1 Balanço de Energia para o Fluido nos Tubos............................................ 80

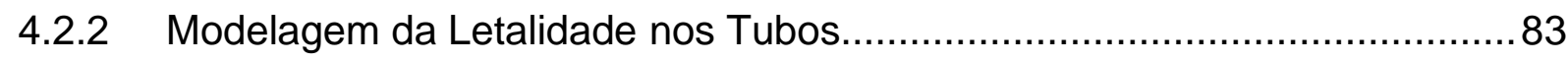

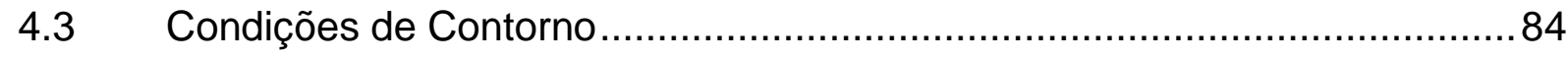


4.3.1 Nos Canais e no Tubo de Retenção para Temperatura ...............................84

4.3.2 Nos Canais e no Tubo de Retenção para Micro-organismos ........................87

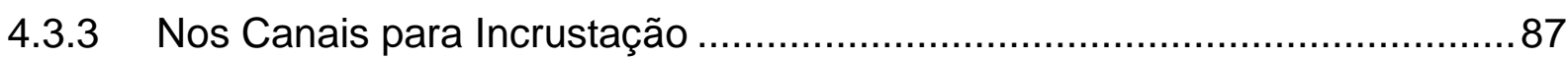

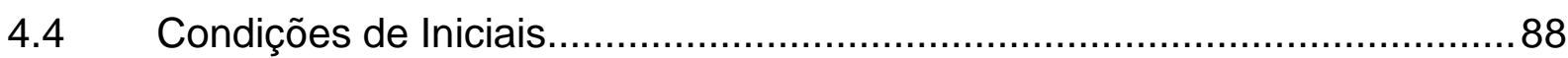

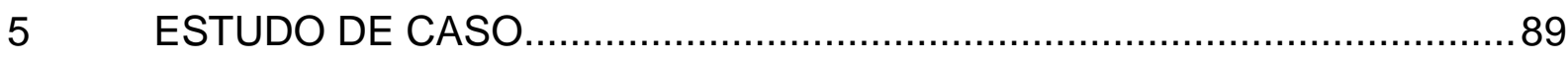

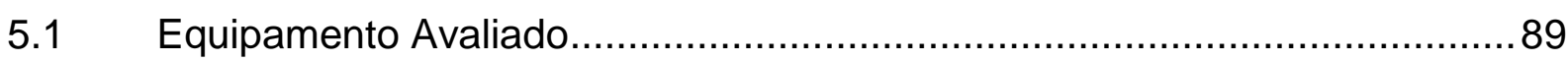

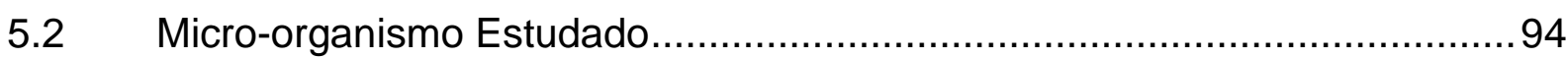

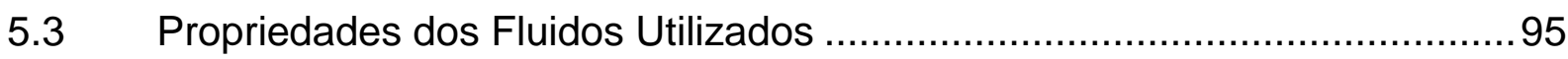

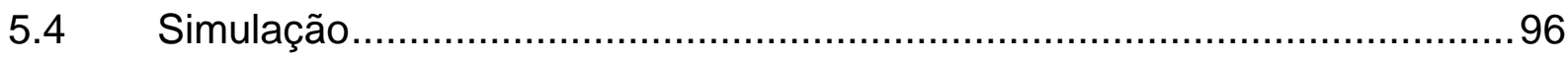

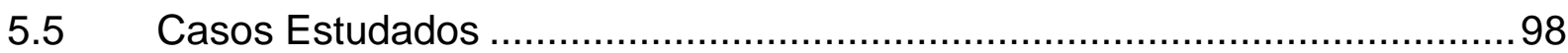

5.6 Validação do Processo Sujeito à Incrustação ………..............................105

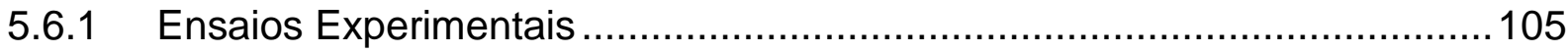

5.6.2 Ajuste do Modelo Empírico.............................................................110

5.6.3 Simulação do Ensaio Experimental ......................................................111

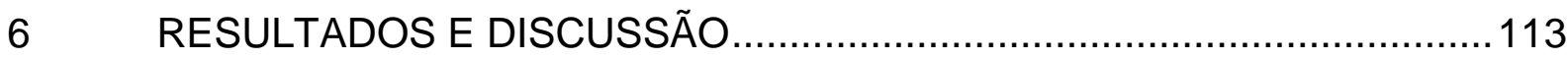

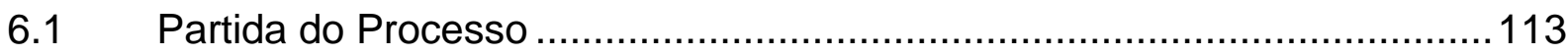

6.2 Pasteurização no Estado Estacionário ...................................................120

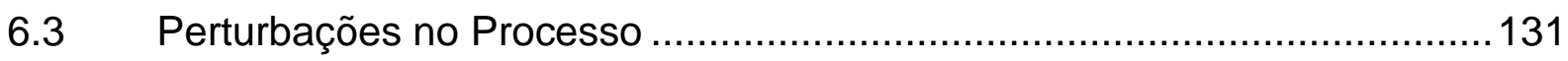

6.3.1 Concentração Inicial de Micro-organismos.............................................132

6.3.2 Temperatura da Água e do Leite Cru ..................................................134

6.3.3 Vazão da Utilidade de Aquecimento.....................................................139

6.3.4 Vazão e Temperatura da Utilidade de Aquecimento e do Leite Cru...........143

6.4 Pasteurização Sujeita à Incrustação ......................................................146

6.4.1 Validação do Processo Sujeito à Incrustação .........................................154

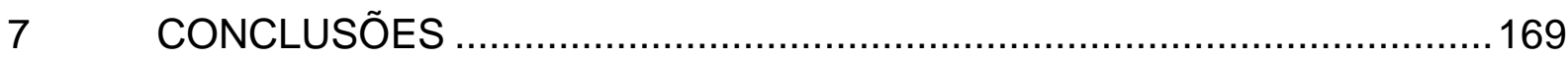

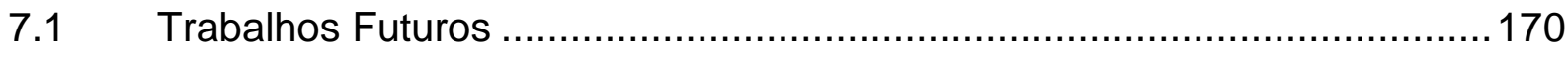

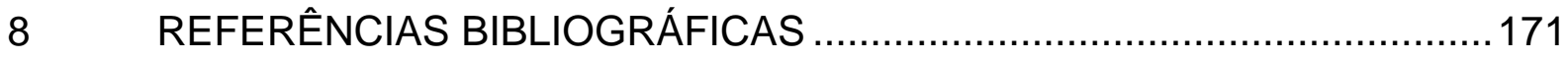




\section{INTRODUÇÃO}

O consumo de leite e de derivados lácteos cresce consistentemente em todo o mundo, inclusive no Brasil, e, por isso, o leite tem grande impacto na economia nacional e mundial (PEDRAS, 2007; EMBRAPA, 2010b). O Brasil está entre os maiores produtores e consumidores de leite bovino do mundo (USDA, 2014).

O leite tem sido utilizado na alimentação humana como fonte de nutrientes essenciais desde os primórdios da civilização (TRONCO, 2008). Ele apresenta composição rica em proteínas, vitaminas, gorduras, carboidratos e sais minerais importantes à saúde dos mamíferos (TAMANINI et al., 2007). Além disso, devido ao seu elevado valor nutritivo, o leite é considerado um ótimo substrato também para o crescimento de vários micro-organismos (SOUZA et al., 1995; SOUZA et al. 2009).

A contaminação microbiológica na indústria de alimentos representa um sério perigo para a saúde dos consumidores e acarreta grandes prejuízos econômicos. Os laticínios, pela própria matéria-prima que utilizam, são particularmente suscetíveis a essas contaminações. Por isso que a qualidade do leite é uma constante preocupação para técnicos e autoridades ligadas à área de saúde, principalmente pelo risco de veiculação de micro-organismos relacionados com surtos de doenças de origem alimentar, podendo até causar óbitos (JAY, 1994; JAY, 2005; SILVA et al., 2008). Portanto, com o intuito de proteger a saúde do consumidor, a legislação brasileira estabelece que todos os derivados de lacticínios, inclusive o leite para consumo, sejam fabricados a partir do leite pasteurizado (BRASIL, 2002; BRASIL, 2003). Contudo, de acordo com a Instrução Normativa 57, publicada em 16 de dezembro de 2011, há uma exceção, que é o queijo artesanal maturado por até 60 dias (BRASIL, 2011).

A extensão da vida útil, ou "vida-de-prateleira" (shelf life), do leite pasteurizado, mantendo as características físico-químicas, nutricionais e sensoriais, é um desafio e uma necessidade industrial, além da redução dos custos de fabricação e a melhoria da cadeia logística.

Neste escopo, a pasteurização contínua, que é um tratamento térmico relativamente brando, no qual o alimento é aquecido a temperaturas inferiores a 100 ${ }^{\circ} \mathrm{C}$, é uma das formas de tratar industrialmente o leite bovino (FELLOWS, 2000). É um processo ao qual o alimento é submetido ao aquecimento indireto até atingir uma 
temperatura definida, seguido de retenção, por tempo determinado, para eliminação de micro-organismos patogênicos, a fim de garantir a inocuidade do produto, seguido de um rápido resfriamento. Isto é, a pasteurização é utilizada como pré-requisito de segurança alimentar, além de conservar as características nutricionais e sensoriais do alimento, prolongando sua a vida útil, de modo inócuo ao consumo humano (FAO, 2014; LADO, YOUSSEF, 2002; SILVA, 2000, PINHEIRO, MOSQUIM, 1991).

No Brasil, a legislação vigente permite dois tipos de pasteurização (BRASIL, 1980; BRASIL, 2002), a lenta, chamada de LTLT (do inglês, Low Temperatura Long Time), e a rápida, HTST (do inglês, High Temperature Short Time), sendo que esta última é uma das mais praticadas pela indústria de laticínios, principalmente com fluidos pouco viscosos, como leite e bebidas lácteas (SILVA, 2000). Esse tratamento térmico faz uso de trocadores de calor, sendo, na maioria das vezes, do tipo trocador de calor a placas ou PHE (do inglês, Plate Heat Exchanger). Os PHEs são os mais usados devido às suas vantajosas características operacionais específicas para indústria de alimentos, por exemplo, a sua grande praticidade de limpeza e higienização, custo e benefício, entre outras (ABU-KHADER, 2012; KIM et al., 1999).

Durante a pasteurização, o controle da temperatura nas diferentes etapas do processo é muito importante, especialmente na saída do tubo de retenção, que mantém o produto no binômio de tempo e temperatura definidos para cada tipo de alimento. Durante a passagem do produto através do tubo de retenção ocorre a inativação dos micro-organismos e enzimas. Se a temperatura de saída do tubo de retenção for menor do que a estabelecida $\left(72^{\circ} \mathrm{C}\right)$, o produto terá que ser novamente processado, pela abertura da válvula diversora de fluxo do equipamento, para garantir a segurança microbiológica e cumprimento da lei. Ao contrário, se a temperatura de saída for maior, o produto estará sendo sobreprocessado. Em ambos os casos, temse maiores perdas de qualidade do alimento e incremento nos custos de produção, respectivamente (IBARROLA et al., 1998, 2002). Exemplificando, estudos quantificam que o desvio de $1^{\circ} \mathrm{C}$ na temperatura do processo, para um mesmo intervalo de tempo, produz um erro de até $25 \%$ no efeito de pasteurização, tanto para mais quanto para menos (HASTING, 1992; IBARROLA et al., 2002).

A consequência de variações deste processo, ou a falta de um controle apurado do mesmo, pode resultar em produtos com carga microbiana extremamente reduzida, acima do necessário - sobreprocessamento -, causando perdas de qualidade sensorial, físico-química e tecnológica e maior custo (JUNG, FRYER, 1999), e, de 
modo oposto, com carga microbiana elevada (abaixo do estipulado pela legislação) subprocessamento (CERF, CONDRON, 2006; GAREDEW et al., 2012).

Embora os processos de pasteurização sejam bastante estudados ao longo dos anos, ainda são responsáveis por muitas perdas nutricionais e sensoriais nos alimentos, diminuindo o seu valor comercial perante aos consumidores (LADO, YOUSSEF, 2002). Em consequência, as indústrias alimentícias visam a minimização da perda de qualidade de seus produtos e, ao mesmo tempo, dos custos operacionais (JUNG, FRYER, 1999).

Baseado nisso, as indústrias precisam compreender e aprimorar os processos térmicos com alimentos (IGUAL et al., 2010) para obterem controle adequado dos mesmos (IBARROLA et al., 1998, 2002). Uma ferramenta importante é a modelagem e a simulação do processo (SHARIFI, NARANDJI, 1995).

A otimização da qualidade é possível porque a cinética de destruição microbiana é diferente da cinética de degradação dos parâmetros nutricionais e sensoriais. Em geral, a altas temperaturas, os micro-organismos são mais sensíveis à destruição térmica do que os parâmetros de qualidade (MAROULIS, SARAVACOS, 2003).

Outro desafio da indústria laticinista é a ocorrência de incrustação. A formação de depósitos oriundos deste fenômeno, em linhas de processamento de leite, é um problema cotidiano enfrentado pela indústria. É frequente em PHEs, durante a pasteurização de derivados lácteos, pois estes são os trocadores de calor mais usados atualmente e também porque são os mais propensos devido às suas características operacionais, sendo a principal: maior área superficial de troca térmica (GEORGIADIS et al., 1997; SANTOS, PEREIRA, 2008).

A incrustação do leite durante o seu tratamento térmico é responsável por uma série de problemas, sendo os principais: a) a eficiência de troca térmica é reduzida consideravelmente devido ao aumento da perda de carga do escoamento e ao aumento da resistência à transferência de calor; b) aumento na aquisição de materiais de limpeza e higienização; c) maiores quantidades de energia e vapor despendidos; d) perda de qualidade nutricional e sensorial dos produtos, etc. (LEWIS, DEETH, 2009; MAHDI et al., 2009; MIGUEL et al., 2014; SANTOS et al., 2011a).

Em resumo, a incrustação causa perda de produtividade industrial e aumento considerável nos custos diretos e indiretos de fabricação de leite e seus derivados (BOUVIER et al., 2014; GEORGIADIS et al., 1997; VISSER, JEURMINK, 1997). Por 
exemplo, nos USA, em 1982, estima-se que a incrustação foi responsável por um ônus de 7 bilhões de dólares em plantas fabris em geral (MÜLLER-STEINHAGEN, 2000).

Uma detalhada modelagem e a validação dos modelos dos processos são essenciais para o engenheiro projetar, otimizar e controlar plantas processadoras de alimentos (MAROULIS, SARAVACOS, 2003; PETERS, TIMMERHAUS, 1991). Nesse sentido, uma alternativa de baixo custo e relativamente simples, para o estudo da incrustação do leite durante a sua pasteurização, é a modelagem matemática.

A modelagem matemática e simulação de processos é uma importante ferramenta para a concepção, avaliação e controle do processo de pasteurização contínua. Neste escopo, os modelos e simulação dinâmica podem ser usados para estudar o problema da incrustação do leite em PHEs, pois esse processo de pasteurização é fundamentalmente transiente (GUTIERREZ, 2014).

Segundo Mokhtar et al. (2012), através da modelagem dinâmica do processo de pasteurização, é possível não só entender melhor como controlar o processo de modo assertivo. Similarmente, Grijspeerdt et al. (2003) afirmam que uma modelagem matemática rigorosa do processo é pré-requisito para simular e otimizar o tratamento térmico visando as condições ótimas de operação.

Então, a fim de entender, controlar e otimizar a pasteurização do leite, preservando a sua qualidade, garantindo a inocuidade, reduzindo a incrustação e minimizando os custos de fabricação, a modelagem matemática e a simulação dos processos são de suma importância.

$\mathrm{Na}$ literatura científica não existem trabalhos de modelagem e simulação da transferência de calor em estado transiente, que contemplem a incrustação do leite juntamente com a letalidade microbiana, do pasteurizador completo (seções de troca térmica, conexões e tubo de retenção), durante o seu tratamento térmico, levando em conta também a perda de calor na retenção.

Baseado nisso, faz-se necessário uma modelagem matemática fenomenológica da pasteurização HTST do leite bovino, a qual leve em consideração também os modelos cinéticos de incrustação do leite e de letalidade da bactéria indicadora, em estado transiente. Com isto, visa-se entender e controlar esse processo térmico, a fim de possibilitar operar no ponto ótimo, garantindo qualidade, segurança dos produtos e, ao mesmo tempo, reduzindo as perdas e os custos fabris. 


\section{OBJETIVOS}

O presente trabalho de pesquisa tem os seguintes objetivos:

1) Desenvolver uma modelagem matemática de base fenomenológica para representar a operação transiente (dinâmica) de um pasteurizador a placas, composto pelas seções de aquecimento, retenção, regeneração e resfriamento, que contemple o efeito da letalidade do tratamento térmico sobre uma bactériaalvo, considerando a incrustação do produto nas placas do equipamento, para um processo contínuo de pasteurização HTST;

2) Realizar a simulação numérica dos modelos desenvolvidos para avaliar a operação do equipamento e o comportamento do processo, considerando perturbações no sistema, a partida do pasteurizador e os cenários com e sem incrustação pelo de estudo de caso.

3) Validar experimentalmente os perfis de temperatura do processo sujeito à incrustação, o fator de incrustação e ajustar os parâmetros empíricos do modelo de incrustação através de ensaios laboratoriais no equipamento avaliado no estudo de caso.

Espera-se que este trabalho possibilite a melhoria do entendimento do processo de pasteurização do leite bovino no trocador de calor a placas, particularmente em relação à transferência de calor, ao efeito da letalidade e devido ao fenômeno da incrustação do produto, com e sem perturbação no sistema. Com isto, busca-se aprimorar os modelos para possibilitar a otimização do processo como um todo. 


\section{REVISÃO DE LITERATURA}

\subsection{Mercado de Leite Bovino}

De acordo com dados da Food and Agriculture Organization of the United Nations (FAO), no mundo, em 2013, foram produzidos mais de 635 milhões de toneladas de litros de leite bovino por ano (AHDB, 2015).

Em termos nacionais, a pecuária bovina é um dos setores mais importantes do agronegócio brasileiro e, consequentemente, da economia do país. O Brasil possui um dos maiores rebanhos bovinos do mundo, liderando o ranking mundial entre os maiores produtores de leite e carne bovina in natura (BRASIL, 2014a; USDA, 2014).

Em 2012, a produção de leite bovino foi por volta de 32,3 bilhões de litros (BRASIL, 2012b). Contudo, apesar da alta produção de leite no país, a produtividade do rebanho nacional ainda é considerada baixa pelo governo brasileiro, cerca de 1.471 litros/vaca/ano. Hoje, a produção nacional é capaz de fornecer à população brasileira aproximadamente 170 litros de leite/habitante/ano, sendo esta quantidade inferior aos 210 litros recomendados pela maioria dos órgãos de saúde nacionais e internacionais (BRASIL, 2014a). Por exemplo, a Organização das Nações Unidas para a Agricultura e Alimentação (FAO) preconiza que o consumo médio de leite bovino, e seus derivados, seja de 215 litros/habitante/ano (TOMBINI et al., 2012).

De acordo com dados do Instituto Brasileiro de Geografia e Estatística (IBGE), no $1^{\circ}$ semestre de 2014, a industrialização de leite bovino foi de 5,8 bilhões de litros, o equivalente a $8,2 \%$ de aumento sobre o mesmo período de 2013 (BRASIL, 2014d). Ainda sobre o ano de 2014, mas no $3^{\circ}$ trimestre, foram adquiridos, pelas indústrias processadoras de leite, 6,267 bilhões de litros do produto, indicando um aumento de 4,6 \% sobre o 3ํtrimestre de 2013 e de $8,1 \%$ sobre o $2^{\circ}$ trimestre de 2014 . A industrialização, por sua vez, foi de 6,258 bilhões de litros (BRASIL, 2014e). Com isso, o Brasil ocupa a 5ª posição no ranking mundial de produção de leite, atrás apenas da União Europeia, Índia, Estados Unidos e China (BRASIL, 2015).

Em termos mercadológicos, o consumo médio de leite bovino líquido representa $37,2 \%$ do volume de leite produzido em 2014 no Brasil, sendo o restante composto por queijo, iogurte, leite em pó, sorvete e bebidas lácteas (USDA, 2014). 


\subsection{Leite Bovino}

\subsubsection{Definição}

Seguindo a legislação brasileira, o Ministério da Agricultura, Pecuária e Abastecimento (MAPA), define leite bovino como: "Entende-se por leite, sem outra especificação, o produto oriundo da ordenha completa, ininterrupta, em condições de higiene, de vacas sadias, bem alimentadas e descansadas" (BRASIL, 1996), sendo o leite denominado de cru quando não passar por nenhum tratamento térmico. Para maiores informações a respeito dos padrões de identidade e qualidade sobre a classificação e os tipos de leites, consultar Instrução Normativa № 51 (BRASIL, 2002).

O leite é um líquido opalescente, branco ou amarelado, de cheiro e sabor bastante característicos (LIMA, 2010). Ele é uma espécie de fluido constituído de uma fase líquida e partículas em suspensão, formando uma emulsão natural, parcialmente estável em condições normais de temperatura e pressão (SGARBIERI, 2004).

A maioria dos constituintes do leite não estão na forma de moléculas livres em solução. Em vez disso, eles existem como estruturas grandes, complexas e associadas, variando desde 30 a $300 \mathrm{~nm}$ para micelas de caseína e até $6.000 \mathrm{~nm}$ para glóbulos de gordura (DAMODARAN et al., 2007). Isso é particularmente verdadeiro para as caseínas, que formam grandes micelas esféricas, sendo que as partículas suspensas na fase líquida são principalmente gotículas de gordura e micelas de caseína (SGARBIERI, 2004). Elas são as responsáveis pela aparência branca do leite (DAMODARAN et al., 2007).

Do ponto de vista físico-químico, o leite é uma mistura complexa e homogênea, constituído por várias substâncias, as quais podem estar na forma de emulsão do tipo óleo em água (lipídeos e vitaminas lipossolúveis), algumas em suspensão coloidal (caseínas, fosfatos inorgânicos, sais de cálcio, etc.) e outras em dissolução verdadeira (vitaminas hidrossolúveis, proteínas do soro e sais minerais) (BYLUND, 1995; GALVÃO JÚNIOR et al., 2010; LIMA, 2010; PEREDA et al., 2005).

\subsubsection{Composição Química e Nutricional}

O leite bovino é composto por uma mistura complexa de lipídeos, proteínas, carboidratos, vitaminas, minerais e, majoritariamente, água. Além disto, contém 
elementos secundários como enzimas (fosfatase, catalase, peroxidase, lipase, etc.) hormônios (IGF-I, progesterona, estrogênio, etc.), gases dissolvidos $\left(\mathrm{O}_{2}, \mathrm{CO}_{2}\right.$ e $\left.\mathrm{N}_{2}\right)$ células somáticas e pigmentos (DAMODARAN et al., 2007; HARDING, 1995; LIMA, 2010; MELNIK et al., 2012; SCHUKKEN et al., 2003; SOUZA et al., 2009).

Sabe-se que as concentrações de todos esses elementos variam de acordo com uma série de parâmetros, tais como: individualidade do animal, raça ou subespécie, alimentação, estágio de lactação, idade, fatores ambientais como estação do ano e temperatura, fatores fisiológicos, patológicos (mastite), tamanho do animal, quartos mamários, porção e intervalo entre ordenhas (COSTA et al., 1992; WALDNER et al., 2014; WEISS et al., 2002). Contudo, mesmo com estas oscilações, são mostrados valores médios de composição química do leite bovino conforme a Tabela 3.1.

Tabela 3.1 - Composição química média do leite bovino fluido.

\begin{tabular}{cc}
\hline Componente & Fração mássica $(\mathrm{g} / 100 \mathrm{~g})$ \\
\hline Água & 86,6 \\
Lipídeos & 4,1 \\
Proteínas & 3,6 \\
Lactose & 5,0 \\
Minerais & 0,7 \\
\hline
\end{tabular}

Fonte: adaptado de Corbin, Whittier, 1965; Nogueira, Canniatti-Brazaca, 2008.

Em termos energéticos, segundo Damodaran et al. (2007), o leite bovino integral apresenta $627 \mathrm{~kJ} / 240 \mathrm{~mL}$ e o semidesnatado apresenta $460 \mathrm{~kJ} / 240 \mathrm{~mL}$.

A lactose (4-O- $\beta$-D-galactopiranosil-D-glicopiranose) é 0 carboidrato predominante do leite bovino, totalizando grande parte dos seus sólidos totais (DAMODARAN et al., 2007). Este dissacarídeo é composto por seus monômeros, glicose e galactose (MAHONEY, 1997), e é encontrado no leite tanto na forma de ligações do tipo $\alpha$ como tipo $\beta$, numa proporção de equilíbrio bioquímico de $\beta / \alpha=1,68$, a $20{ }^{\circ} \mathrm{C}$ (NICKERSON, 1965). Contudo, no leite bovino existem outros tipos de carboidratos, ou açúcares, porém em baixas concentrações, por exemplo, aproximadamente, $100 \mathrm{mg} / \mathrm{L}$ de oligossacarídeos (RENNER, 1983).

Do conteúdo lipídico, a maior parte é composta por triglicerídeos ou triacilgliceróis (96 \% a $98 \%$ de seu total), sendo já identificados mais de 400 ácidos graxos tanto saturados como insaturados. Os triacilgliceróis estão presentes como 
glóbulos de gordura, numa concentração média de $10^{10}$ glóbulos por litro, de 0,2 a 15 $\mu \mathrm{m}$ de diâmetro, emulsionados por material de membrana (DAMODARAN et al., 2007; LIMA, 2010; TRONCO, 2008; TAMIME, 2009). De acordo com Grummer (1991), cerca de $70 \%$ dos ácidos graxos do leite são saturados, 25 \% são ácidos graxos monoinsaturados e $5 \%$ são poli-insaturados. É possível observar a composição lipídica geral do leite na Tabela 3.2.

Tabela 3.2 - Composição lipídica média do leite bovino integral (3,2 \% de gordura).

\begin{tabular}{cc}
\hline Lipídeo & Fração mássica $(\mathrm{g} / 100 \mathrm{~g})$ \\
\hline Triglicerídeos & 95,80 \\
Diglicerídeos & 2,25 \\
Ácidos graxos livres e monoglicerídeos & 0,36 \\
Fosfolipídeos & 1,11 \\
Colesterol & 0,46
\end{tabular}

Fonte: adaptado de Jensen et al., 1991.

Além disso, o leite bovino contém algumas das vitaminas solúveis em lipídeos lipossolúveis - e também as solúveis em água - hidrossolúveis (Tabela 3.3).

Tabela 3.3 - Principais vitaminas presentes no leite bovino fluido cru.

\begin{tabular}{cc}
\hline Vitamina & Quantidade $(\mathrm{mg} / 100 \mathrm{~mL})$ \\
\hline B2 (riboflavina) & 0,17 \\
B3 (niacina) & 0,09 \\
B5 (ácido pantotênico) & 0,34 \\
B6 (piroxidina) & 0,06 \\
C (ácido ascórbico) & 2,10 \\
E (tocoferóis) & 0,10 \\
A & 159,0 U.I. ${ }^{*}$ \\
D & 2,2 U.I. ${ }^{*}$
\end{tabular}

Fonte: adaptado de FOX e McSWEENEY, 1998 e WALSTRA e JENNESS, 1984. ${ }^{*}$ U.I. = Unidades Internacionais para vitaminas. 
O leite contém a maioria dos minerais importantes à nutrição humana, tais como: fósforo, potássio, sódio, cálcio, ferro e magnésio (FOX et al., 2015; PINHEIRO, MOSQUIM, 1991; WHITE, DAVIES, 1958).

\subsubsection{Proteínas Lácteas}

As proteínas do leite podem ser classificadas em quatro grupos, de acordo com suas propriedades físico-químicas e estruturais: a) caseínas; b) proteínas do soro; c) proteínas das membranas dos glóbulos de gordura; d) enzimas e fatores de crescimento (LOURENÇO, 2000; SGARBIERI, 1996). Contudo, do ponto de vista nutricional e industrial, as proteínas do leite de maior aplicação e valor econômico são as caseínas e as proteínas do soro, sendo elas distribuídas entre si numa proporção de $80 \%$ de caseína e $20 \%$ de proteínas do soro (DAMODARAN et al., 2007; LIVNEY, 2010; SMIT, 2003).

Observa-se pela Tabela 3.4 a distribuição das proteínas majoritárias do leite bovino, bem como os seus subgrupos em termos de concentração e porcentagem.

Tabela 3.4 - Concentração das principais proteínas do leite bovino.

\begin{tabular}{cccc}
\hline \multicolumn{1}{c}{ Proteína } & $\mathrm{g} / \mathrm{L}$ & Fração mássica $(\mathrm{g} / 100 \mathrm{~g})$ \\
\hline Caseínas: & $24-28$ & 80,0 \\
& $\alpha_{S 1}$ & $12-15$ & 34,0 \\
$\alpha_{S 2}$ & $3-4$ & 8,0 \\
$\beta$ & $9-11$ & 25,0 \\
$\mathrm{~K}$ & $3-4$ & 9,0 \\
$\Gamma$ & $1-2$ & 4,0 \\
Proteínas do Soro: & $5-7$ & 20,0 \\
B-lactoglobulinas & $2-4$ & 9,0 \\
a-lactalbumina & $1-1,5$ & 4,0 \\
Proteose-peptonas & $0,6-1,8$ & 4,0 \\
Albumina sérica & $0,1-0,4$ & 1,0 \\
Imunoglobulinas & $0,6-1,0$ & 2,0 \\
Lactoferrina & 0,1 & - \\
\hline
\end{tabular}

Fontes: adaptado de Damodaran et al., 2007; Livney, 2010; Sgarbieri, 2005. 
Devido às propriedades físico-químicas, as proteínas lácteas proporcionam efeitos funcionais de grande interesse tecnológico como: solubilidade, absorção, retenção de água e de gordura, capacidade emulsificante e estabilidade das emulsões, capacidade espumante e estabilidade de espuma, geleificação, formação de filmes comestíveis e biodegradáveis, formação de micropartículas, melhoria nas propriedades sensoriais e na aceitação dos produtos (CHATTERTON et al., 2006; MODLER, 2000; VEITH, REYNOLDS, 2004; WONG et al., 1996).

Uma das diferenças básicas entre as duas principais frações proteicas do leite, a caseína e as proteínas do soro, é que as caseínas são termoresistentes e precipitam mediante acidificação em seu ponto isoelétrico (PI). Já as do soro, em sua forma nativa são termosensíveis, mas não precipitam em seu PI (VISSER, JEURNINK, 1997).

As micelas de caseína apresentam-se altamente hidratadas $(4,4 \mathrm{~mL}$ de água por grama de caseína) (SGARBIERI, 2005). Sobre sua composição, elas contêm por volta de $92 \%$ de proteínas, sendo do tipo $\alpha_{s 1}: \alpha_{s 2}: \beta$ : к caseínas em proporção de $3: 1: 3$ $: 1$, respectivamente, além dos $8 \%$ de sais do leite, compostos principalmente por fosfato de cálcio, magnésio e citratos (DAMODARAN et al., 2007).

A distribuição média destes sais no leite é dada por: cálcio inorgânico $(2,87 \%)$, fosfato $(2,89 \%)$, citratos $(0,4 \%)$ e pequenas quantidades de magnésio, sódio e potássio (ROLLEMA, 1992; SCHMIDT, 1980).

\subsubsection{Microbiota do Leite}

De acordo com Lima (2010), o leite bovino é estéril no interior da vaca, desde que o animal esteja sadio. Entretanto, o leite entra em contato com diversos microorganismos durante a sua ordenha e/ou após a mesma, sendo pelo contato com aparelhos e utensílios, ar, pó, terra, pessoas e instalações industriais. Ou seja, a sua contaminação por micro-organismos pode ocorrer de modo endógeno (no caso de animais doentes) e / ou exógeno (externamente). Neste caso, os principais contaminantes microbiológicos do leite são: vírus, fungos, leveduras e bactérias (JAY, 2005; TRONCO, 2008). Ao mesmo tempo, sabe-se que o leite bovino é um meio adequado para o desenvolvimento de vários tipos de micro-organismos devido à combinação ideal entre o seu pH próximo da neutralidade e sua composição rica em água livre, carboidratos, proteínas e gorduras (HAYES, BOOR, 2001; TAMIME, 2009). 
Portanto, é por este motivo que logo após a sua ordenha, que deve ser totalmente higiênica e controlada, o leite deve ser mantido sob refrigeração (abaixo de $10^{\circ} \mathrm{C}$ ) por tempo de, no máximo, 6 horas (BRASIL, 2002). Contudo, alguns autores recomendam que a refrigeração do leite deva ser realizada a temperaturas ainda menores, abaixo de $5{ }^{\circ} \mathrm{C}$ (COUSIN, 1982; HOFFMANN et al., 1996). Para exemplificar o efeito do tempo e da temperatura de armazenamento no leite bovino cru, tem-se a previsão populacional microbiana no produto cru na Tabela 3.5.

Tabela 3.5 - Previsão populacional microbiana (UFC/mL) no leite bovino cru.

\begin{tabular}{cccccc}
\hline Temperatura & Início & 6 horas & 12 horas & 24 horas & 48 horas \\
\hline $10^{\circ} \mathrm{C}$ & 10 & 12 & 15 & 41 & 62 \\
$20^{\circ} \mathrm{C}$ & 10 & 17 & 242 & $6,13 \times 10^{3}$ & $3,57 \times 10^{6}$ \\
\hline
\end{tabular}

Fonte: Behmer, 1987.

Contagens elevadas de micro-organismos no leite cru evidenciam a existência de falhas nos procedimentos de manipulação, higienização e sanidade do animal, podendo, certamente, comprometer a qualidade, a segurança e diminuir a vida útil do produto final (NÖRNBERG et al., 2009). Em outras palavras, a deterioração microbiana é o principal fator limitante para a extensão da vida de prateleira (shelf life) do leite pasteurizado e de seus derivados lácteos (BOOR, 2001; SANTOS et al., 2013). Portanto, a extensão da validade do leite pasteurizado dependerá fundamentalmente da qualidade do leite cru, ou seja, da contagem inicial e do tipo de micro-organismos presentes (SCHMIDT et al., 2012), do número de células somáticas bovina e das condições de armazenamento a que é submetido (BARBANO et al., 2006).

Nesse sentido, a carga bacteriana inicial do leite possui influência direta na qualidade do leite pasteurizado, pois, mesmo que o tratamento térmico proporcione a destruição dos micro-organismos deteriorantes, os termodúricos, esporulados e as enzimas termoestáveis dos psicrotróficos são capazes de causar posteriores alterações no leite e derivados (HUCK et al., 2007; 2008). Desta forma, a qualidade de um produto acabado está diretamente relacionada com as características microbiológicas da matéria-prima usada (HUCK et al., 2007; SANTOS et al., 2003b).

De acordo com Jay (2005), no leite bovino cru é possível encontrar diversos micro-organismos, desejáveis, inertes e indesejáveis (patogênicos ou deterioradores). Os ditos como desejáveis podem, por exemplo, ser aqueles utilizados industrialmente 
na fermentação láctica do leite, a fim de fabricar iogurtes e outros derivados (ORDOÑEZ, 2005). Contudo, os indesejáveis, que são classificados como deterioradores, têm a principal função de metabolizar substratos do leite, modificando negativamente as suas características sensoriais (COUSIN, 1982; NÖRNBERG et al., 2009). Os patogênicos também são indesejáveis, sendo estes os mais preocupantes, pois podem acarretar em surtos de toxi-infecções alimentares aos consumidores, podendo levá-los a óbito (JAY, 2005; SILVA et al., 2008).

Os patogênicos mais importantes no leite são: bacilo de Koch ou Mycobacterium tuberculosis (causador da Tuberculose), Salmonella typha e Salmonella paratyphi (causadoras da Febre Tifoide), Brucillo melitensis (Febre de Malta), Streptococcus, Listeria spp., E. coli (CASP, ABRIL, 2003; JAY, 1994; MENEZES et al., 2014; REZER, 2010; TAMIME, 2009) e Coxiella burnetii (febre Q) (CERF, CONDRON, 2006).

\subsection{Processamento do Leite Pasteurizado}

É possível observar o diagrama genérico de fabricação de leite bovino padronizado integral do tipo B pasteurizado fluido pela Figura 3.1.

Figura 3.1 - Diagrama geral de fabricação de leite padronizado integral tipo B.

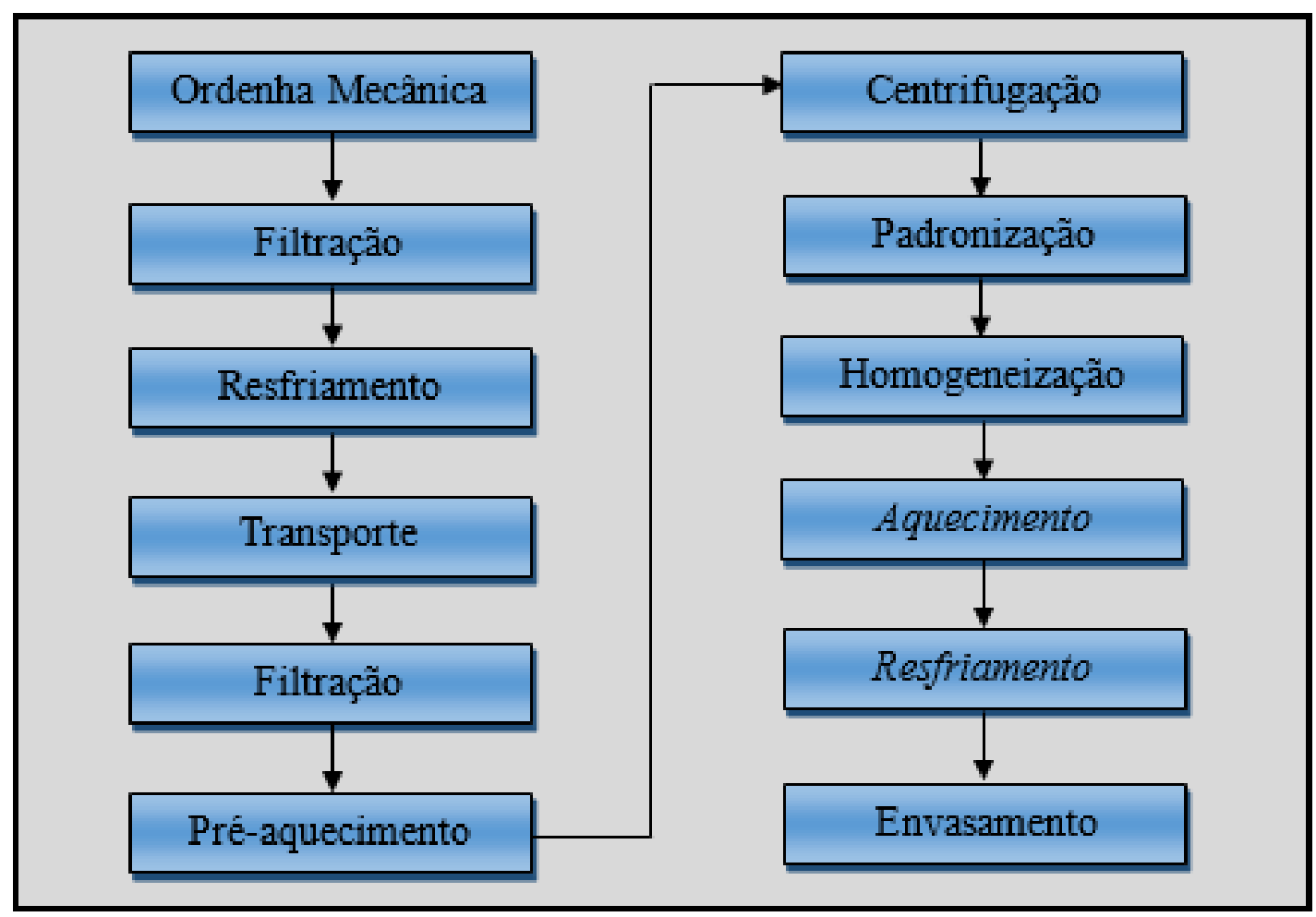

Fonte: adaptado de Bylund, 1995; Venturini Filho, 2010. 
A industrialização do leite bovino cru resulta em diversos tipos de produtos, tais como leite fluido, em pó ou concentrado, queijos, iogurte, requeijão, manteiga, sorvete, bebidas lácteas e leite fermentado (VENTURINI FILHO, 2010). Todos esses produtos lácteos, inclusive o próprio leite processado, devem passar obrigatoriamente pela etapa de pasteurização (BRASIL, 2002; BRASIL, 2003; LEWIS, DEETH, 2009).

De modo similar, pela Figura 3.2 é possível observar a malha do processo genérico para obtenção de leite pasteurizado padronizado fluido.

Figura 3.2 - Processo de fabricação de leite pasteurizado padronizado fluido.

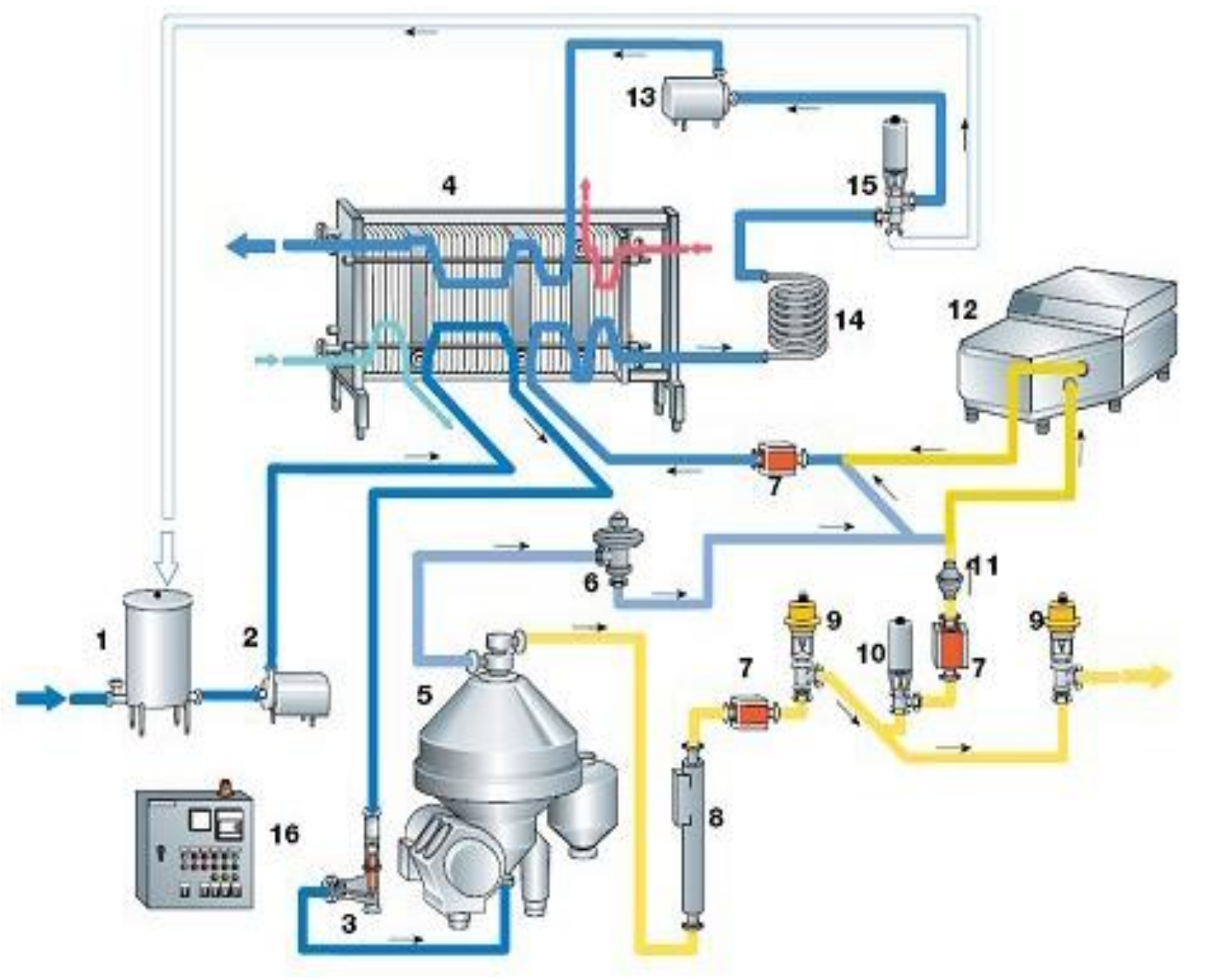

1. Tanque

2. Bomba de produto

3. Controlador de fluxo

4. Trocador de calor a placas

5. Separador

6. Válvula de controle de pressão

7. Transmissor de fluxo

8. Transmissor de densidade
9. Válvula de vazão

10. Válvula de bloqueio

11. Válvula de controle

12. Homogenizador

13. Bomba de fluxo

14. Tubo de retenção

15. Válvula diversora

16. Controlador PID

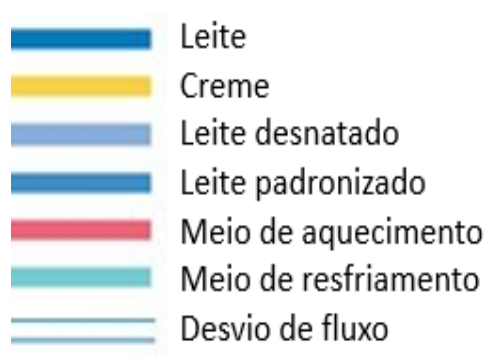

Fonte: adaptado de Bylund, 1995. 
No início do processo, logo que o leite bovino cru sai do tanque de resfriamento (armazenamento), refrigerado, ele passa por uma simples filtragem através de membranas a fim de reter possíveis partículas de impurezas de diâmetro grosseiro, tais como areia, terra, entre outras, especificamente para ordenhas manuais (BYLUND, 1995). Na sequência, vai para a etapa de centrifugação ou clarificação, a qual tem dois objetivos concomitantes. O primeiro é a eliminação de impurezas, como células epiteliais, eritrócitos e leucócitos, ou qualquer partícula em suspensão com diâmetro superior a $10 \mu \mathrm{m}$ (VENTURINI FILHO, 2010). Já o segundo objetivo é a separação de boa parte da gordura do leite - o creme. Ou seja, neste momento ocorre a separação de determinadas partículas sólidas do leite cru devido a diferenças de densidades (BYLUND, 1995). Essa separação pode ser realizada a quente ou a frio, porém como a diferença de densidade entre o meio gorduroso e o plasma é maior entre 32 e $38^{\circ} \mathrm{C}$, as fábricas pré-aquecem o leite antes da etapa de desnate a fim de garantir uma melhor eficiência (ALAIS, 1985; DAMODARAN et al., 2007).

Em seguida, é realizada a padronização do leite com a própria gordura retirada na etapa anterior. Isso ocorre principalmente pelo fato do teor de lipídeos do leite estar entre os componentes que mais variam naturalmente (WALSTRA et al., 1999).

A homogeneização é realizada para evitar a formação de uma camada de gordura indesejável no leite, ou seja, evitar a coalescência dos glóbulos de gordura, a nata. Além disso, a homogeneização favorece o aumento da brancura do leite (DAMODARAN et al., 2007). Isso é conseguido pelo processo de redução do tamanho dos glóbulos de gordura, incremento de seu número e aumento da área superficial de 5 a 10 vezes, pelo uso de alta pressão, quando o fluido passa por um pequeno orifício (BYLUND, 1995; FOX et al.,1960; VENTURINI FILHO, 2010). Frequentemente, as indústrias realizam a homogeneização do leite pré-aquecido, pois a baixas temperaturas alguns lipídeos podem estar cristalizados (não fundidos), resultando em baixíssima eficiência operacional (DAMODARAN et al., 2007; TAMIME, DEETH, 1980). Contudo, a homogeneização também oferece desvantagens tecnológicas para o leite, tais como: redução da estabilidade térmica e mais suscetibilidade a oxidação lipídica por enzimas e/ou luz e calor (DAMODARAN et al., 2007).

Algumas plantas produtoras realizam a etapa de desaeração do leite para evitar alterações oxidativas durante o seu armazenamento e melhorar a condução de calor na etapa de pasteurização. Para este caso, o leite fluido é pulverizado numa câmara de vácuo e o ar dissolvido é removido por uma bomba de vácuo (FELLOWS, 2000). 
A etapa de mais crítica durante a industrialização do leite bovino cru para produção de leite pasteurizado é, de fato, a etapa de processamento térmico ou aquecimento. Neste instante o produto troca calor com o fluido de aquecimento, por tempo e temperatura pré-determinados. O principal objetivo é reduzir drasticamente a carga microbiana do leite a fim de torná-lo seguro ao consumo humano (BRASIL, 1952).

\subsection{Pasteurização}

A pasteurização é chamada assim em homenagem ao trabalho de Louis Pasteur (1822 - 1895), um químico-microbiológico francês, que, por volta de 1864, desenvolveu um método para prevenir a fermentação anormal do vinho devido à destruição de determinados micro-organismos pelo uso de calor (DE JONG, 2008).

Tecnicamente, a pasteurização é um tratamento térmico controlado no qual o alimento é submetido ao aquecimento indireto, por tempo determinado, seguido de resfriamento, para minimizar danos ao produto, como perdas sensoriais, tecnológicas e nutricionais. Portanto, este processo busca garantir a segurança microbiológica, aumentar a vida de prateleira e, ao mesmo tempo, preservar a qualidade dos alimentos (LEWIS, HEPPELL, 2000).

Esse tipo de processo faz uso de equipamento denominado pasteurizador, que pode ser do tipo a placas ou tubular, e é usado para vários produtos alimentícios, como sucos, leite, cerveja, purês, etc. (FELLOWS, 2000).

Desde 1980, o The International Dairy Federation definiu pasteurização como: "Um processo aplicado ao produto (alimento) com o objetivo de minimizar possíveis riscos à saúde devido aos micro-organismos patogênicos do leite através de tratamento térmico, o qual resulte em mínimas modificações físicas, químicas e sensoriais ao produto" (DE JONG, 2008).

No Brasil, com o intuito de proteger a saúde do consumidor, a legislação estabelece que os derivados de lacticínios, inclusive o leite para consumo, sejam fabricados a partir do leite pasteurizado (BRASIL, 2002; BRASIL, 2003). Na instrução normativa $\mathrm{n}^{\circ}$ 51, de 18 de setembro de 2002, anexo $\mathrm{V}$, é possível encontrar informações definidas pelo MAPA para a pasteurização do leite (BRASIL, 2002). 
Atualmente, na indústria láctea, os principais tratamentos térmicos são classificados de acordo com o binômio tempo versus temperatura e o foco microbiano, e podem ser observados na Tabela 3.6.

Tabela 3.6 - Principais tipos de tratamento térmico da indústria láctea.

\begin{tabular}{cccc}
\hline Tipo & Tempo $(\mathrm{s})$ & Temperatura $\left({ }^{\circ} \mathrm{C}\right)$ & Foco microbiano \\
\hline Termização & $15-20$ & 65 & Psicotróficos \\
LTLT & $20-30$ min & $63-74$ & Patogênicos \\
HTST & $15-20$ & $72-85$ & Todos \\
UHT & $3-10$ & $130-140$ & Todos + esporos
\end{tabular}

Fonte: adaptado de De Jong, 2008; Fox, Mcsweeney, 1998; Villamiel et al., 2009.

Segundo Fellows (2000), a pasteurização é um tratamento térmico relativamente ameno, em que o alimento é aquecido abaixo de $100^{\circ} \mathrm{C}$. Já a esterilização comercial consiste em tratamentos que superam os $100^{\circ} \mathrm{C}$ (CASTRO, 2005).

Na Figura 3.3 observa-se o esquema genérico do pasteurizador contínuo, com as suas 4 seções térmicas - aquecimento, regeneração, retenção e resfriamento.

Figura 3.3 - Esquema de um processo de pasteurização com trocadores a placas.

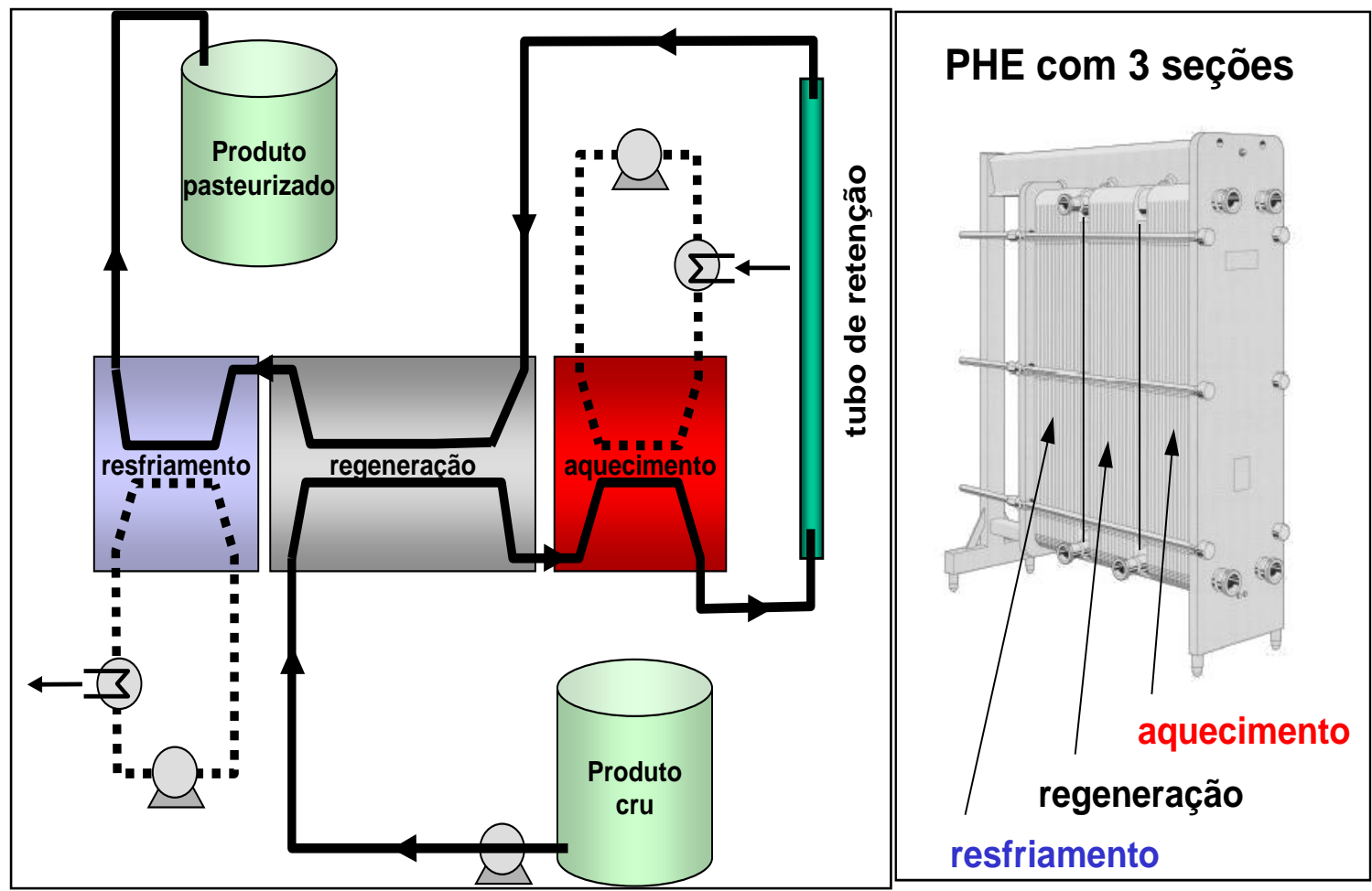

Fonte: Gut e Pinto, 2003b. 
Na seção de aquecimento do produto, que é escoado devido à ação de bomba, ocorre a troca indireta de calor entre o fluido quente (utilidade industrial), que pode ser água líquida pressurizada ou vapor d'água (FELLOWS, 2000). Já para resfriamento do produto, após o seu aquecimento, é usada água fria, salmoura ou glicol, também através de troca térmica indireta (LEWIS, DEETH, 2009).

A pasteurização rápida ou HTST tem sido largamente utilizada em indústrias de maior porte, principalmente nas que operam com grandes volumes (SILVA, 2000). É por este motivo que se faz necessário um exímio controle do processo, especialmente do binômio tempo \& temperatura na saída do tubo de retenção, pois será nesta etapa que a qualidade microbiológica e a sensorial do produto pode ser comprometida (LEWIS, HEPPELL, 2000; MOKHTAR et al., 2012). Logo, tanto a seção de aquecimento quanto o tubo de retenção são as etapas mais críticas do processo (SARAVACOS, KOSTAROPOULOS, 2002).

Caso o produto fique por mais tempo, ou a uma temperatura maior, no tubo de retenção, ele estará sendo sobre-processado, gastando mais energia e comprometendo a qualidade do mesmo. Contrariamente, caso ele fique menos tempo, ou a menor temperatura, ele estará sub-processado, representando risco à saúde do consumidor e apresentará menor vida útil. Então, neste caso, o alimento deverá ser descartado ou novamente processado. Em ambas as situações, isso acarretará perdas e maiores custos industriais. Baseado nisso, é necessária uma compreensão e controle do processo de pasteurização bem como da operação do equipamento (GUT et al., 2005; GUTIERREZ, 2013; HASTING, 1992; MANIK et al., 2004).

A inativação de micro-organismos presentes nos alimentos, quando estes são submetidos ao calor, pode ser representada por cinética de primeira ordem, ou seja, a variação da concentração de células viáveis com o tempo de processamento é proporcional à concentração de células viáveis presentes (ESTY, MEYER, 1922). Segundo Gava (2007) e Maroulis, Saravacos (2003), a temperatura constante, para processo em batelada, tem-se:

$$
\frac{d C_{A}}{d t} \propto C_{A} \quad \text { ou } \quad \frac{d C_{A}}{d t}=-k_{A} \cdot C_{A}
$$

em que $C_{A}$ é a concentração de micro-organismos viáveis, $t$ é o tempo e $k_{A}$ é a constante de proporcionalidade, definida como velocidade específica de morte celular. 
A extensão do tratamento térmico necessário para estabilizar um alimento é estipulada principalmente pelo valor do parâmetro $D$ (tempo de redução decimal) da enzima ou micro-organismo mais resistentes ao calor. Ele caracteriza a resistência térmica de um micro-organismo, ou composto de interesse, e depende de vários fatores, como, por exemplo, a composição química do alimento, temperatura do processo, entre outros. De acordo com a definição, o valor $D$ é o tempo necessário para destruir $90 \%$ da população do micro-organismo alvo ou a inativação de 90 \% de certo pigmento, vitamina ou enzima, a uma dada temperatura. Ou seja, será também o tempo necessário para reduzir um ciclo logaritmo. Portanto, quanto maior o valor de $D$, maior será a resistência ao tratamento térmico aplicado (BALL, OLSON, 1957; FELLOWS, 2000; GAVA, 2007; MAROULIS, SARAVACOS, 2003).

Outros parâmetros muito usados no estudo de tratamento térmico são $F$ e $z$ (FELLOWS, 2000; MAROULIS, SARAVACOS, 2003). F (letalidade) é definida como o tempo necessário para destruir certa carga desejada de micro-organismos alvo, a uma temperatura especificada (GAVA, 2007). Ela é uma grandeza utilizada para representação do efeito do tratamento térmico nos alimentos e indica a intensidade do mesmo em relação à morte microbiana (BERTELI et al., 2013). $z$ é definido como a variação da temperatura necessária para reduzir em 90 \% o valor de $D$.

Em relação à pasteurização do leite bovino cru, a legislação brasileira obriga que imediatamente após a pasteurização, o produto assim processado, deve apresentar teste qualitativo negativo para a enzima fosfatase alcalina ou fosfomonoesterase alcalina, teste positivo para a enzima peroxidase e enumeração de coliformes a 30/35 ${ }^{\circ} \mathrm{C}$ menor do que 0,3 NMP/mL da amostra (BRASIL, 2002), como forma de garantir que a temperatura e o tempo recomendados tenham sido alcançados.

A fosfatase alcalina, que é encontrada naturalmente no leite, é uma enzima termosensível (LIMA, 2010). Porém, como ela apresenta resistência térmica um pouco maior do que os patógenos formadores de esporos, é usada para avaliar a eficiência da pasteurização (FOX, MCSWEENEY, 1998). A sua completa inativação térmica ocorre a $72{ }^{\circ} \mathrm{C}$ por $16 \mathrm{~s}$, em condições normais. Contudo, é possível a sua reativação no leite já processado quando em estocagem acima de $5{ }^{\circ} \mathrm{C}$ (SGARBIERI, 2005).

Segundo Pelczar et al. (1981), as relações originais de tempo e temperatura de pasteurização do leite foram obtidas com o micro-organismo Mycobaterium tuberculosis - indicador alvo -, considerado como o agente patogênico mais termoresistente capaz de ocorrer no leite. Esta bactéria é destruída quando exposta a uma 
temperatura de $140^{\circ} \mathrm{F}\left(60^{\circ} \mathrm{C}\right)$ durante $10 \mathrm{~min}$. Entretanto, mais tarde foi descoberto que a Coxiella burnetii, agente etiológico da febre $Q$, transmissível pelo leite, pode sobreviver por um aquecimento a $143^{\circ} \mathrm{F}\left(61,7^{\circ} \mathrm{C}\right)$, durante $30 \mathrm{~min}$. Então, como resultado destas descobertas, foram estabelecidas as atuais temperaturas de pasteurização baseadas neste micro-organismo indicador.

A pasteurização do leite é responsável, também, por uma série de mudanças e reações complexas, de natureza física, química, bioquímica, nutricional e sensorial, sendo algumas desejadas e outras indesejadas. As variações mais frequentes e importantes dizem respeito ao decaimento do $\mathrm{pH}$, precipitação do fosfato de cálcio, desnaturação das proteínas do soro e sua interação com as caseínas, isomerização da lactose, reação de Maillard e modificação das micelas de caseína do leite (DANNENBERG, KESSLER, 1998; DE JONG, 2008; FELLOWS, 2000; LEWIS, DEETH, 2009; TAMIME, DEETH, 1980; WALSTRA, JENNESS, 1984; WALSTRA, 1990).

\subsection{Trocador de Calor a Placas}

Embora haja relatos sobre a primeira patente de um equipamento similar a um trocador de calor, na Alemanha, por volta de 1878 (LAWRY, 1959), considera-se que o primeiro trocador de calor a placas (do inglês, Plate Heat Exchanger) surgiu no ano de 1923 (PHE Ltda., 2002). Contudo, apenas na década de 1930 que os PHEs foram de fato introduzidos comercialmente no mercado industrial (GUT, 2003), mas só começaram a se tornar mais populares na década de 1960 (KAKAÇ, LIU, 2002).

Os trocadores de calor a placas são os mais usados em indústrias de manufatura em geral (SRIHARI et al., 2005). Esses equipamentos foram criados especialmente para aplicações sanitárias devido à facilidade de higienização e limpeza, sendo, então, largamente utilizados em operações industriais dos setores alimentícios e farmacêuticos. Contudo, também são utilizados em plantas químicas. Sua principal aplicação é para processos contínuos de pasteurização e esterilização de alimentos, mas também para resfriamento (GUT, PINTO, 2003b; GUT, PINTO, 2003c; KIM et al., 1999; SRIHARI et al., 2005; ZHENHUA et al., 2008). Na Figura 3.4 é possível observar alguns exemplos de PHEs industriais.

Os PHEs são preferidos pela indústria laticinista, em vez dos trocadores tubulares, devido a algumas vantagens: desempenho superior de transferência de 
calor, menor gradiente de temperatura, maior turbulência, facilidade para higienização, alta compactação e menor custo (BANSAL, CHEN, 2006; LEWIS, DEETH, 2009). Também apresentam altos valores de coeficiente de troca térmica devido à sua geometria, a qual promove grande turbulência a baixa velocidade (ALFALAVAL, 1969, 1971).

Figura 3.4 - Alguns modelos de PHEs industriais comerciais.
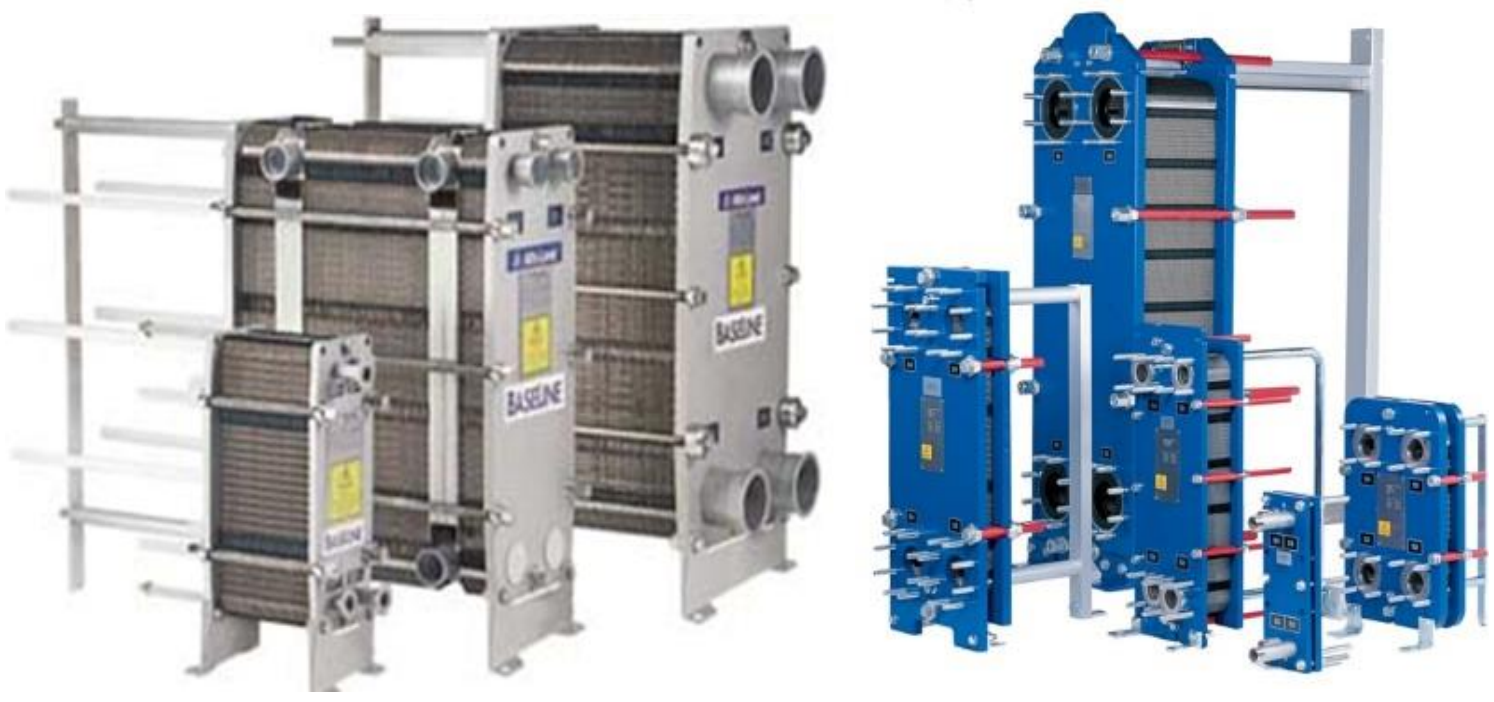

Fonte: Alfa Laval, 2014; Grupo TecSul, 2014.

Contudo também apresentam desvantagens, como a relativa necessidade de manutenção devido à reposição de gaxetas e placas (LEWIS, DEETH, 2009). Outra desvantagem é que operam com pressões e temperaturas limitadas (SHAH, SEKULIC, 2003), isto é, até $1,5 \mathrm{MPa}$ e $150{ }^{\circ} \mathrm{C}$ quando se deseja operar a altas eficiências térmicas (GUT, PINTO, 2003b). Em alguns casos, estas condições podem ser modificadas, por exemplo, em unidades PHE do tipo lamela que não apresentam a flexibilidade de placas e gaxetas, pode-se operar com pressões de até 4,1 MPa e a $800^{\circ} \mathrm{C}$ (ABU-KHADER, 2012).

Os trocadores de calor a placas são propensos à incrustação por causa de seus estreitos canais de fluxo (DELPLACE et al., 1994) e os pontos de contato entre as placas adjacentes (BELMAR-BEINY et al., 1993). De modo similar, segundo Bansal e Chen (2006) e Gut e Pinto (2003b), os trocadores tubulares também apresentam problemas de incrustação.

Os trocadores de calor a placas são constituídos, na maioria das vezes, por finas placas metálicas com corrugações (SHAH, SEKULIC, 2003). Eles nada mais são do 
que uma estrutura composta de um suporte para as placas independentes, geralmente confeccionadas em aço inoxidável, sustentadas por duas barras, uma superior e outra inferior, e presas pela compressão dos parafusos tensores encaixados nas placas denominadas móvel e fixa (GRUPO TECSUL, 2014). Um típico trocador de calor a placas é composto basicamente por um pacote de finas placas metálicas prensadas em um pedestal, como mostra a Figura 3.5. O pedestal é normalmente construído em aço carbono com pintura anticorrosiva. A placa fixa e a placa de aperto possuem bocais para a conexão das tubulações de alimentação e de coleta dos fluidos (GUT, PINTO, 2003b).

Figura 3.5 - Principais componentes dos PHEs.
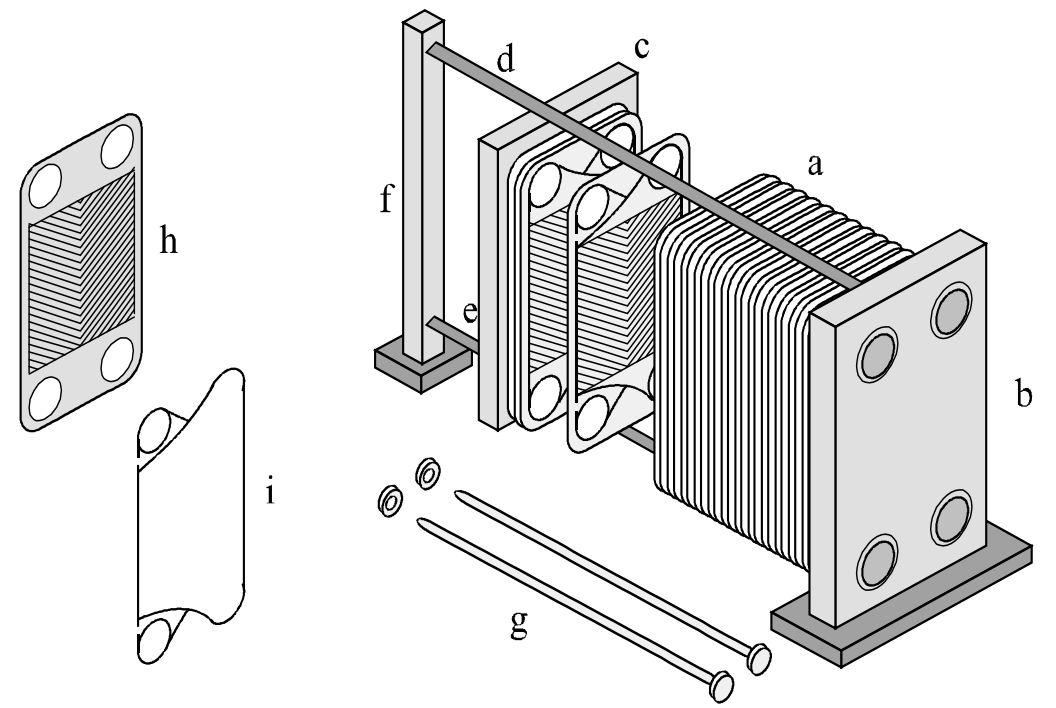

a. Pacote de placas aberto

b. Placa fixa com conexões

c. Placa de aperto móvel

d. Barramento superior

e. Barramento inferior

f. Coluna de sustentação

g. Parafusos de aperto

h. Placa corrugada chevron

i. Gaxeta

Fonte: Gut, Pinto, 2003b.

Os trocadores de calor a placas de aço inoxidável são os mais utilizados na indústria de laticínios em decorrência de suas inúmeras vantagens tecnológicas e operacionais (BANSAL, CHEN, 2006; MAHDI et al., 2009).

A área de troca térmica por placa varia de 0,03 a 3,6 $\mathrm{m}^{2}$, em média (GUT, PINTO, 2003b). Por exemplo, um PHE com 250 placas compactadas, pode apresentar até $100 \mathrm{~m}^{2}$ de área superficial de troca térmica (MAROULIS, SARACOS, 2003).

Entre cada par de placas são usadas gaxetas para formar canais de escoamento pelos quais os fluidos quentes e frio circulam alternadamente, trocando calor, indiretamente, através das placas metálicas (GUT, 2003). Além disso, essas placas têm corrugações (ondulações) que possibilitam obter maior turbulência no escoamento dentro dos canais, favorecendo os efeitos de transferência de calor e 
quantidade de movimento. Somado a isso, a elevada velocidade induzida pelo bombeamento, reduz a espessura dos filmes de contorno para se obter elevados coeficientes de transferência de calor (FELLOWS, 2000). Estas ondulações também aumentam a resistência mecânica do pacote de placas, que pode ter de 3 a 700 placas. O tipo mais comum de corrugações são a chevron ("espinha de peixe") e a washboard ("tábua de lavar"), sendo que o ângulo de inclinação das ranhuras chevron é um parâmetro muito importante para o dimensionamento do PHE pois ele tem forte influência sobre os coeficientes de troca térmica e sobre a perda de carga dos fluidos (GUT, PINTO, 2003b).

A transferência de calor em um trocador geralmente envolve convecção em cada fluido e condução através da parede que separa os dois fluidos (ÇENGEL, GHAJAR, 2014). Na Figura 3.6 tem-se um esquema geral de como é a distribuição do escoamento entre os fluidos quente e frio.

Figura 3.6 - Esquema do escoamento e troca de calor nas placas do PHE.
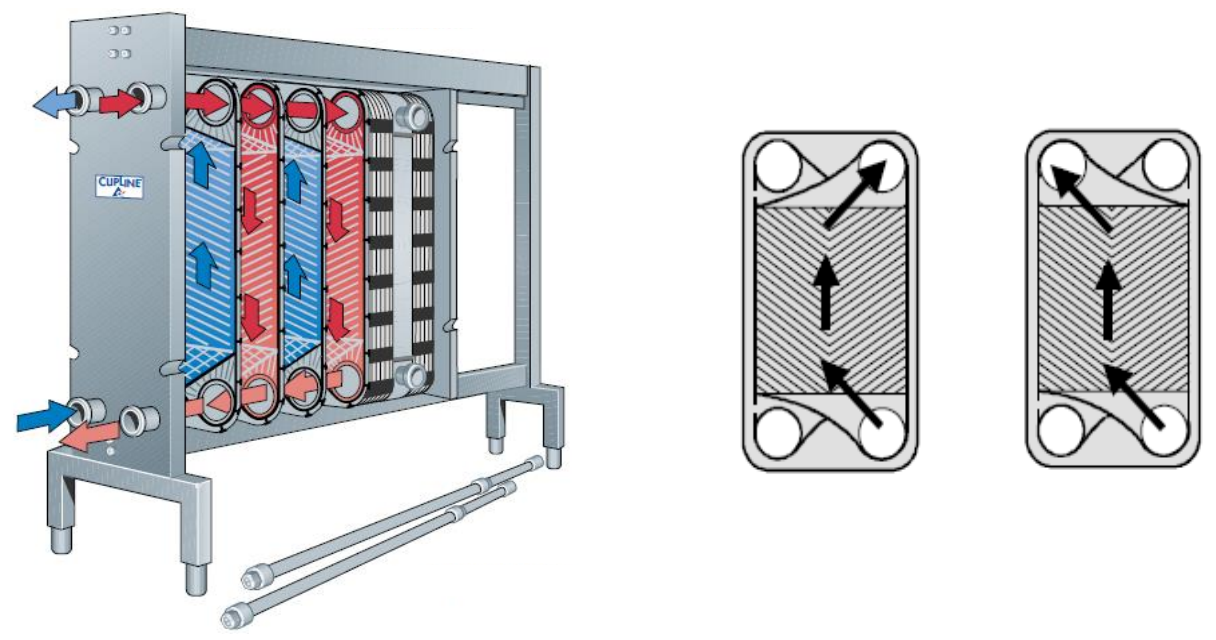

Fonte: Bylund, 1995; Gut, 2003.

Embora a grande maioria dessas placas sejam elaboradas em aço inoxidável (BANSAL, CHEN, 2006), também podem ser encontradas de materiais como titânio e outras ligas metálicas (SEC HEAT EXCHANGER, 2014). O espaço entre as placas costuma estar entre 2,5 e $5 \mathrm{~mm}$, mas, no mercado estão disponíveis outras medidas, particularmente para fluidos viscosos (LEWIS, DEETH, 2009).

Cada uma das placas do PHE possui orifícios nos cantos para a passagem dos fluidos e são seladas nas extremidades por gaxetas, também chamadas de juntas, que são de material elastomérico (GUT, PINTO, 2003b). As gaxetas do trocador 
podem ser encontradas em diversos materiais, tais como Etileno-Propileno-Dieno (EPDM), outros tipos de borrachas sintéticas e materiais (SEC HEAT EXCHANGER, 2014). Outros materiais, como o amianto, podem ser usados quando se deseja trabalhar com temperaturas superiores a $150{ }^{\circ} \mathrm{C}$ (GUT, PINTO, 2003b).

O número total de placas térmicas do pacote é designado por $N_{P}$ e o número de canais formados é chamado de $N_{C}$, sendo que a sua relação é dada pela equação 3.2.

$$
N_{C}=N_{P}-1
$$

Segundo Gut r Pinto (2003c) e Pint e Gut (2002), a configuração de um PHE (ou de uma ou de múltiplas seções) define a distribuição do escoamento dos fluidos quentes e frios no interior do conjunto de placas do equipamento, além de outras partes do conjunto. Para configurar um trocador de calor a placas, além de $N_{C}$, são utilizados os seguintes parâmetros (GUT, 2003):

- $\quad Y_{f}$ (tipo de escoamento no canal);

- $Y_{h}$ (localização dos fluidos quente e frio);

- $\quad P^{I}$ e $P^{I I}$ (número de passes dos lados $I$ e $I I$ do PHE);

- $\emptyset$ (localização relativa das conexões de alimentação);

Considerando o número de canais, o arranjo de passes, a localização das conexões de entrada e saída dos fluidos quente e frio e o tipo de escoamento, são inúmeras as possibilidades de configuração de um PHE. A escolha do tipo de configuração exerce grande influência sobre o desempenho térmico e hidrodinâmico do processo, sendo, então, importante a realização de uma análise durante o projeto de implementação e dimensionamento do equipamento (GUT, 2003).

\subsection{Incrustação}

O acúmulo de material nas superfícies dos trocadores de calor, durante suas operações, é dito como incrustação, do inglês, fouling (KAKAÇ, LIU, 2002; KAKAÇ et al., 2012). A incrustação dos trocadores de calor é um fenômeno indesejável e um dos maiores problemas na área da transferência de calor (KAKAÇ et al., 2012). Este 
problema acomete vários setores industriais, tais como o químico, petroquímico e alimentício (BOTT, 1995; FRYER, BELMAR-BEINY, 1991).

Geralmente, o material depositado na superfície dos equipamentos e tubulações pode ser material biológico, inorgânico, químico derivado de reações, cristalino e particulado. Ele dependerá do tipo de fluido (gás ou líquido) que estiver sendo processado no trocador de calor (BOTT, 1995).

Em termos globais, por exemplo, uma pesquisa realizada pelo governo da Nova Zelândia, em 1990, avaliou mais de dois mil trocadores de calor em 200 indústrias processadoras. O resultado foi que quase $90 \%$ dos equipamentos verificados apresentavam alguma forma de incrustação (KHO, MÜLLER-STEENHAGEN, 1999). Já, nos Estados Unidos da América (USA), há 3 décadas, o custo médio devido a problemas de incrustação foi estimado entre 3,9 e 7,0 bilhões de dólares por ano (REBELLO et al., 1988). Do mesmo modo, na Holanda, o custo anual devido a problemas de incrustação é de aproximadamente US\$40,0 milhões (GRIJSPEERDT et al., 2003).

Especificamente na indústria de laticínios, a incrustação dos equipamentos durante o processamento do leite é causada pela formação de material depositado sobre a superfície das placas dos PHEs, consistindo em sua maioria por proteínas e sais minerais oriundos do mesmo (DE JONG, 2008; FRYER, BELMAR-BEINY, 1991; VISSER, JEURNINK, 1997; TE GIFFEL, VAN ASSELT, 2009).

Bott (1995), Bouvier et al. (2014), Fryer e Belmar-Beiny (1991), Georgiadis et al. (1997) e Jeurnink (1996) afirmam que a incrustação é responsável por causar problemas do tipo: a) decaimento no coeficiente de troca térmica global $(U)$, prejudicando a transferência de calor; b) no escoamento do produto causa perda de carga e, consequentemente, diminuição na eficiência das bombas; c) perda de produto principalmente por sua aderência aos equipamentos e tubulações incrustados; d) contaminação do alimento devido a formação de biofilmes microbianos e depósitos para os mesmos (LEHNER et al., 2005). Ou seja, como a incrustação provoca redução na troca térmica e queda na pressão durante a pasteurização do produto, as fábricas, para manter a temperatura do produto no set point, aumentam a temperatura do meio de aquecimento, isto é, mais vapor (LEWIS, DEETH, 2009). Logo, resultará em maiores custos operacionais e perda do controle do processo (DE JONG, 2008; GEORGIADIS et al., 1997). Ou seja, aproximadamente $80 \%$ dos custos operacionais são relacionados à incrustação, por isso torna-se claro que o 
entendimento e correto controle deste problema é necessário na indústria láctea (DE JONG, 1996).

Por exemplo, somente na França, o custo total devido à incrustação na indústria de laticínios, em 1991, foi estimado em 1 bilhão de francos franceses (CLIAUDAGNE, 1991). De modo similar, esse problema tem resultando custos altíssimos para as indústrias americanas (KAKAÇ et al., 2012). Na Europa, os custos anuais adicionais, causados pela incrustação, foram iguais a 260 milhões de euros (BRINKMANN, 1986).

Na Figura 3.7 tem-se a placa de um típico trocador de calor a placas industrial, incrustado após horas de processamento com leite bovino.

Figura 3.7 - Placa de um PHE incrustado após processamento de leite bovino.

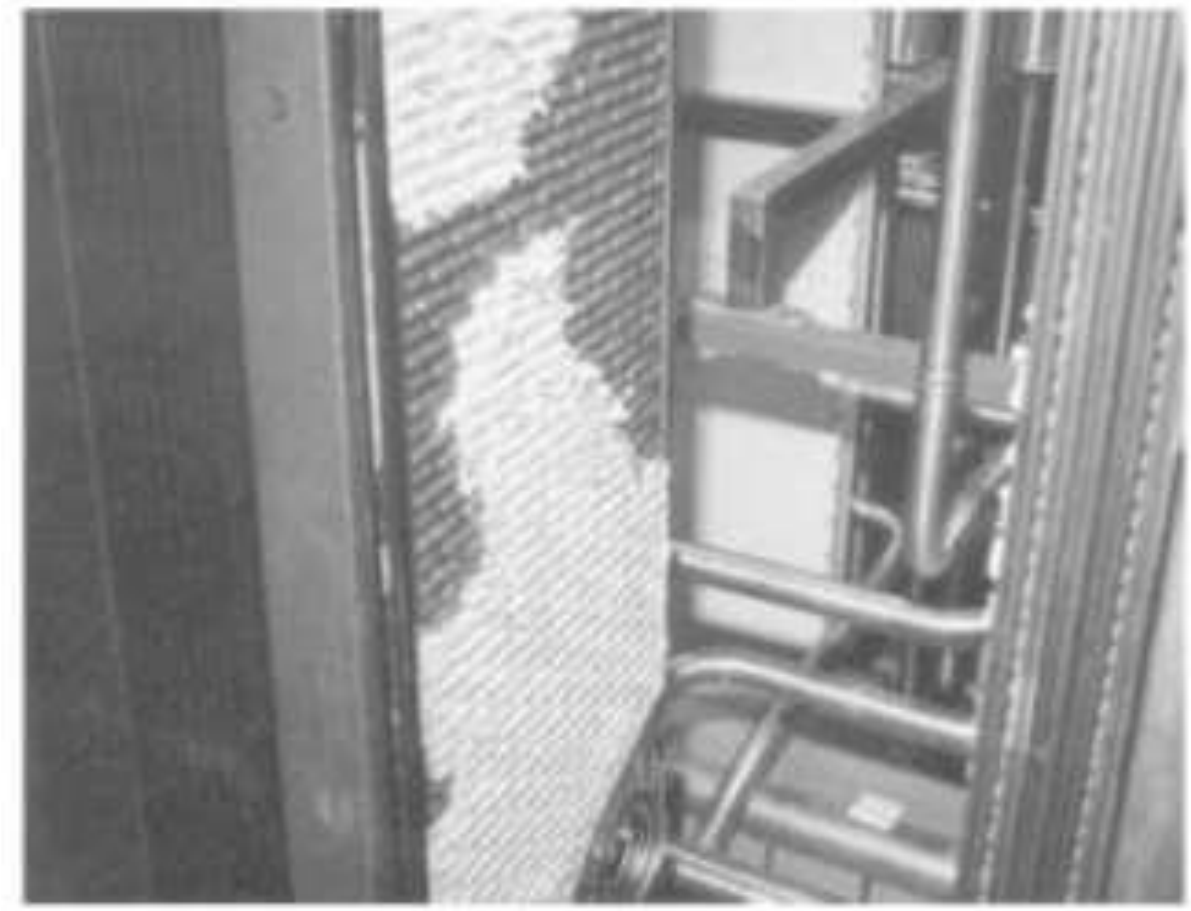

Fonte: De Jong, 2008.

No Brasil, as indústrias de laticínios se deparam com problemas operacionais devido à incrustação do leite, mas também de outros produtos derivados nãoacabados, como por exemplo, massa láctea usada em iogurtes e queijos, a qual também é pasteurizada em trocadores de calor convencionais. Em termos práticos, esse inconveniente é registrado pelos históricos de temperatura e pressão do processo, ao longo do tempo, mas sem qualquer ação por parte dos fabricantes.

Embora haja uma quantidade considerável de trabalhos a respeito do fenômeno de incrustação do leite bovino em trocadores de calor, esse problema está somente 
parcialmente compreendido devido à natureza complexa do leite e dos seus processos fabris (BANSAL, CHEN, 2006; BELMAR-BEINY, FRYER, 1992; BELMARBEINY et al., 1993; BELL, SANDERS, 1944; BOXLER et al., 2014; BURTON, 1967, 1968; CHANGANI et al., 1997; GEORGIADIS, MACCHIETTO, 2000; GOTHAM et al., 1992; JUN, PURI, 2006; LEEDER, 1956; MAHDI et al., 2009; PETIT et al., 2013). Além disso, não foi possível traduzir esse entendimento numa forma efetiva de melhorar os projetos dos PHEs por modelos de incrustação (DE JONG, 2008).

Embora os exatos mecanismos e reações entre os diferentes componentes do leite, durante a incrustação, ainda não tenham sido totalmente compreendidos, a relação entre a desnaturação da proteína $\beta$-lactoglobulina e a incrustação em PHEs já foi, em grande parte, elucidada. Essa correlação, entre a desnaturação das proteínas do leite e o efeito da incrustação, já foi confirmada por diversas investigações (DALGLEISH, 1990; DANNENBERG, 1986; DE JONG, VAN DER LINDEN, 1992; DE JONG et al., 1992, 1993; FRYER, 1989; LALANDE et al., 1985).

A Figura 3.8 ilustra um esquema do mecanismo de deposição desta proteína durante a pasteurização do leite.

Figura 3.8 - Esquema de incrustação da proteína $\beta$-lactoglobulina sobre a placa.

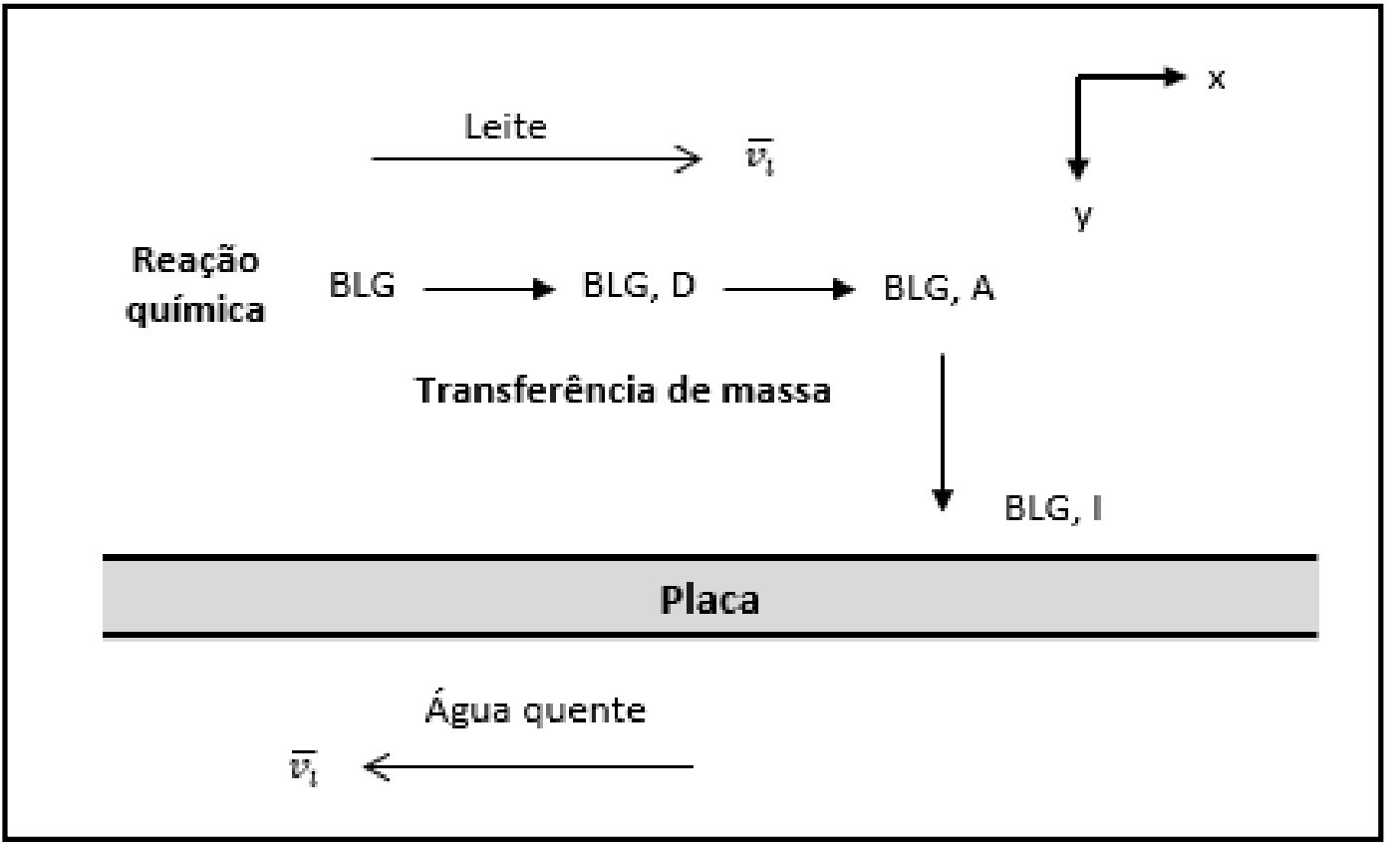

Legenda: $B L G=$ proteína $\beta$-lactoglobulina; $B L G, D=$ proteína $\beta$-lactoglobulina desnaturada; $B L G, A$ = proteína $\beta$-lactoglobulina agregada e $B L G, I=$ proteína $\beta$ lactoglobulina incrustada na placa. Fonte: adapatado de Georgiadis et al. (1998b). 
A proteína $\beta$-lactoglobulina do soro lácteo, em termos de incrustação, é a que mais corrobora na formação da incrustação do leite durante o seu processamento, pois é a fração mais abundante e uma das mais termosensíveis (LEl et al., 2011; SANTOS et al., 2011b; VISSER, JEURNINK, 1997), sendo iniciado o seu processo de desnaturação a partir dos $70{ }^{\circ} \mathrm{C}$ (ERABIT et al., 2014; FRYER, BELMAR-BEINY, 1991).

Pela Figura 3.8, é mostrado como ocorre o mecanismo de incrustação da proteína láctea $\beta$-lactoglobulina. Primeiramente, tem-se a desnaturação da proteína, seguida de sua agregação. Após isso, a sua aderência na superfície da placa do PHE, completando o fenômeno da incrustação mediante à reação química e transferência de massa (DE JONG, 2008; GEORGIADIS et al., 1998b). A forma ativa da $\beta$ lactoglobulina também é capaz de se agregar com outras proteínas lácteas, sendo adsorvida na parede de troca térmica (DE JONG et al., 1992).

Além disso, há vários fatores que podem afetar a incrustação do leite e de produtos lácteos em trocadores de calor, tais como: teor de cálcio, $\mathrm{pH}$, quantidade de bolhas de ar dissolvida, idade do leite, variações sazonais, composição química da superfície de troca térmica e sua geometria e tempo de processo (DE JONG, 2008).

Na verdade, de acordo com Burton (1988), o fenômeno da incrustação do leite pode ser classificado com base na composição química do material aderido e na temperatura do processo, sendo tipo A e tipo B. O primeiro caso, resultado em depósitos mais esponjosos, brancos e suaves, com 50 a $70 \%$ de proteínas lácteas, 30 a $35 \%$ de minerais (cálcio e fosfato) e com $5 \%$ de lipídeos, e numa temperatura entre $75^{\circ} \mathrm{C}$ e $115^{\circ} \mathrm{C}$ (BELMAR-BEINY et al.,1993; DAUFIN et al.,1987). O segundo tipo de incrustação é formado para processos com temperaturas superiores a $115^{\circ} \mathrm{C}$, responsável por depósitos de coloração cinza, quebradiços (duros) e com estrutura granular. Sua composição química é de 70 a 80 \% de minerais, 15 a $20 \%$ de proteínas e 5 \% de lipídeos (FRYER et al., 2006; LALANDE et al., 1985; LYSTER,1965). Essa diferença de composição de material depositado nas paredes dos equipamentos é importante para avaliar o melhor procedimento de limpeza química e física das tubulações e máquinas que processam leite (DE JONG, 1997).

Nesse sentido, o modelo fenomenológico da incrustação do leite, embora complexo, deve levar em contar efeitos cinéticos e de transferência de massa, ambos para a $\beta$-lactoglobulina, dependendo também da temperatura do produto, do tempo 
de operação (acúmulo de massa nas placas), da velocidade de escoamento (BERGAMAN et al., 2011) e das propriedades intrínsecas do leite (DE JONG, VAN DER LINDEN, 1992; DE JONG et al., 1992).

\subsection{Modelagem e Simulação}

De acordo com Hangos e Cameron (2001) um modelo é a imitação da realidade e a modelagem matemática é uma forma particular de sua representação. Similarmente, segundo Triola (2005) o modelo matemático é uma função matemática que se "ajusta" aos dados reais ou os descreve de modo muito próximo à realidade. Ou seja, um modelo nada mais é do que uma abstração matemática de algo real (SEBORG et al., 2004).

Os modelos matemáticos de transferência de calor e perda de carga são necessários para o projeto e dimensionamento de PHEs. Com base em restrições hidráulicas e térmicas, é possível determinar a configuração de PHE e/ou custos fixos operacionais mínimos. Baseado nisso, a qualidade dos resultados da posterior otimização, dependerá fortemente da precisão e abrangência do modelo matemático obtido (CAREZZATO et al., 2007; IBARROLA et al., 2002).

Uma quantidade considerável de trabalhos a respeito da modelagem, simulação e/ou otimização dos processos térmicos do leite em trocadores de calor sujeitos, ou não, à incrustação, já foi realizada dada a importância deste tema (AGUIAR, GUT, 2014; BENNETT, 2007; BENNING et al., 2003; BOUVIER et al., 2014; CHOI et al., 2013; CHANGANI et al., 1997; FRYER, 1989; GAO et al., 2010; GEORGIADIS et al., 1998a; GRIJSPEERDT et al., 1999; GEORGIADIS, MACCHIATO, 2000; GRIJSPEERDT et al., 2004; GUT et al., 2014; GUTIERREZ et al., 2014; SAHO et al., 2005; JUN, PURI, 2005a; JUN, PURI, 2006; MAHDI et al., 2009; PETIT et al., 2013).

Contudo, os mecanismos da incrustação ainda não estão totalmente compreendidos, principalmente devido à natureza complexa do leite bovino (BANSAL, CHEN, 2006). Isto é, ainda não existem modelos satisfatórios que contemplem todas as variáveis necessárias para otimização deste processo (DE JONG, 2008).

O fato do leite mostrar fortes variações sazonais, como resultado de diferenças em sua composição, dificulta ainda mais o estudo da incrustação e geração de modelos matemáticos confiáveis (BURTON, 1967). 
Vários autores têm modelado os processos térmicos sujeitos à incrustação em trocadores de calor, principalmente do tipo PHE, com base na representação unidimensional do fenômeno (ANSARI et al., 2003; DELPLACE et al, 1994; DELPLACE, LEULIET, 1995; DELPLACE et al, 1997; FRYER, SLATER, 1985; GEORGIADIS et al., 1998b; GEORGIADIS, MACCHIETTO, 2000; GRIJSPEERDT et al., 2004; JUN et al., 2004; PETERMEIER et al., 2002; RIBEIRO, ANDRADE, 2002; SANDU, LUND, 1982; SCHREIER, FRYER, 1995; YOON, LUND, 1994). Porém, isto constitui em uma simplificação devido ao efeito da geometria das placas utilizadas na indústria (YOUCEF et al., 2009).

A modelagem dinâmica de um PHE, com 6 canais, durante o aquecimento do leite bovino, foi realizada por Georgiadis e Macchietto (2000). Foi levada em conta a cinética de desnaturação de proteínas. O modelo obtido em regime transiente permitiu analisar a queda do coeficiente global de troca térmica ao longo do tempo, devido à incrustação do leite. O trabalho foi realizado para três diferentes configurações do trocador a fim de estudar os efeitos da incrustação. Os resultados experimentais concordaram de modo plausível com os dados teóricos e com a simulação. Os autores afirmaram que devido à natureza turbulenta no escoamento do leite no PHE a incrustação não foi tão severa quanto no caso do trocador tubular, além de que a incrustação não foi uniforme ao longo dos canais. Para este trabalho, o software de simulação utilizado foi o gPROMS. Contudo, não levou em conta o efeito da letalidade e foi considerado apenas no trocador de calor da seção de aquecimento.

Em outros estudos, tais como os de Bouvier et al. (2014), De Bonis, Ruocco (2006); Grijspeerdt et al. (2003); Jun et al. (2003); Jun e Puri (2004), Jun et al. (2004), Jun e Puri (2006), Mahdi et al. (2009); Narataruksaa et al. (2008) e Youcef et al. (2009), modelos com representação bidimensional do fenômeno, representando o fluxo hidrodinâmico do fluido, foram utilizados para prever a distribuição da temperatura com maior exatidão do que um modelo unidimensional.

Youcef e colaboradores (2009) utilizaram um modelo de incrustação bidimensional dinâmico para estudar a incrustação do leite dentro de um trocador de calor a placas de 12 canais com escoamento contra-corrente. Este estudo foi baseado no desempenho hidrodinâmico e termodinâmico do trocador, visando uma minimização dos gastos de produção e a qualidade do produto. Os resultados mostraram que a quantidade de massa incrustada sobre a superfície do trocador de calor está fortemente relacionada com a temperatura e o tempo de processamento do 
leite. Por outro lado, constataram também que a incrustação foi altamente dependente das condições de operação do processo, mais especificamente da velocidade do escoamento. É afirmado que o grau de incrustação é, também, relacionado com o número de Reynolds, sendo inversamente proporcional ao mesmo. Isto é, a incrustação é menor para maiores valores de Re devido ao aumento de forças de cisalhamento no escoamento, estando isso de acordo com Belmar-Beiny et al. (1993).

A modelagem bidimensional do fenômeno é algo complexo e dispendioso, de modo que a maioria dos autores fazem este tipo de estudo para um único canal ou parte deste (CHOI et al., 2013; GRIJSPEERDT et al., 2003; JUN, PURI, 2005a; LI et al., 2013; PETERMEIER et al., 2002; PIEPIÓRKA-STEPUK, DIAKUN, 2014).

Piepiórka-Stepuk e Diakun (2014), investigando a incrustação do leite bovino nas placas do PHE, utilizando a técnica de fluidodinâmica computacional (CFD) pelo método dos volumes finitos, perceberam que os campos de velocidade do escoamento do fluido variaram consideravelmente ao longo das placas. As maiores velocidades foram observadas perto dos orifícios de entrada e saída das placas e em suas bordas. Já as menores velocidades foram visualizadas na região central das placas. Ainda, segundo os autores, nestas regiões de menor velocidade, a deposição de material incrustado foi mais acentuada e o processo de limpeza industrial no local (do inglês, Cleaning in Place, CIP) foi menos efetivo. Isso mostra que quanto maior a vazão do produto, menor será a sua incrustação.

Muitos trabalhos têm sido realizados com fluidos que simulam o leite bovino (AUGUSTIN et al., 2007; BOXLER et al., 2014; BOXLER et al., 2012; ERABIT et al., 2014; GAO et al., 2010; PATEL et al., 2013; PETIT et al., 2011; ROSMANINHO, MELO, 2008; ROSMANINHO et al., 2008). Na maioria destes casos, opera-se com água e proteínas do soro lácteo. Isso ocorre por alguns motivos: a) alta complexidade de se trabalhar com leite bovino in natura cru (BURTON, 1968; BURTON, 1988); b) também porque são amplamente usados como ingredientes funcionais em iogurtes, bebidas lácteas, formulações alimentares, molhos, etc. (BELMAR-BEINY et al., 1993); c) contém mais de $50 \%$ de $\beta$-lactoglobulina, que é a proteína considerada responsável por formação de depósitos (DE JONG, 2008; LALANDE, RENE, 1988).

Embora haja diversos estudos a respeito da modelagem e simulação da pasteurização do leite bovino, em trocador de calor sujeito à incrustação, ainda existe uma carência de informação sobre a complexa cinética de desnaturação e agregação proteica (DANNENBERG, 1986; GOTHAM et al., 1992; MURUGESAN, 
BALASUBRAMANIAN, 2013). Portanto, a ligação entre os modelos de incrustação e os trocadores de calor ainda não está totalmente explorada (DE JONG, 2008).

É possível encontrar vários trabalhos sobre modelagem e controle preditivo microbiológico no leite cru e no leite tratado (CHEN, HOOVER, 2003; CHEN, 2007; GUAN et al., 2005; GOUGOULI et al., 2011; VISSERS et al., 2007).

Piyasena et al. (1998) desenvolveram um modelo linear para descrever a inativação da Listeria innocua e monocytogenes em leite bovino integral em tratamento HTST, em um pasteurizador de escala piloto, com uma temperatura de referência de $72{ }^{\circ} \mathrm{C}$, a partir de dados históricos do processo térmico. Após a realização da simulação dos modelos, os autores concluíram que eles podem ser usados para simular o comportamento microbiológico durante a pasteurização.

McKellar e Piyasena (2000) realizaram a modelagem e a simulação da letalidade (ou efeito da pasteurização) sobre a enzima $\alpha$-L-fucosidase em leite bovino, em decorrência da pasteurização HTST, levando em conta dados históricos deste processo térmico. Os autores concluíram que é possível usar esse modelo como ferramenta preditiva ao tratamento de termização do leite.

Uma modelagem fenomenológica em estado estacionário foi realizada em uma única seção do PHE, de um pasteurizador a placas, sendo considerado o efeito da letalidade, para leite bovino, sobre a bactéria $C$. burnetii (GUT et al., 2004).

Um trabalho de modelagem matemática foi elaborado por Teleken et al. (2011) para descrever o crescimento de populações de microrganismos ( $L$. monocytogenes, Pseudomonas spp., S. flexneri e B. cereus) no leite bovino. Os modelos foram validados satisfatoriamente de acordo com os autores.

Frühling (2013) modelou matematicamente o desenvolvimento de bactérias no leite cru com influência da temperatura a fim de estimar qual era o melhor período para a remoção do leite do tanque de expansão durante o seu armazenamento, sendo que a variável resposta de interesse foi a contagem bacteriana total.

Existem vários estudos que comprovam a necessidade de tratar o leite termicamente a fim de inativar, dentre outras, a bactéria patogênica Coxiella burnetii, a qual causa a febre $Q$ em seres humanos (ENRIGHT et al., 1957; LENNETTE et al., 1952; MARRIE, RAOULT, 1997; MALTEZOU, RAOULT, 2002).

Não existem muitos trabalhos que contemplem a modelagem e a simulação da unidade de pasteurização completa, com todas as suas seções de troca térmica e o tubo de retenção. Um dos poucos artigos publicados é o de Gutierrez et al. (2014). 
Nesse estudo, os autores desenvolveram uma modelagem fenomenológica dinâmica. Foi feita a simulação e validação do modelo obtido. Contudo, não foi levado em conta o efeito térmico da letalidade e nem da incrustação do leite bovino no equipamento.

Consequentemente, uma modelagem matemática dinâmica mais completa e realística do processo de pasteurização do leite sob incrustação é necessária para um correto controle do processo, visando a otimização dos custos operacionais e da qualidade dos produtos (GRIJSPEERDT et al., 2003; GUTIERREZ, 2013). 


\section{MODELAGEM MATEMÁTICA DA PASTEURIZAÇÃO}

Neste trabalho, a modelagem matemática do processo contínuo de pasteurização do leite bovino em trocador de calor a placas é parcialmente baseada em Gutierrez et al. (2014), no qual fez-se a modelagem e a simulação dinâmica e a validação em um pasteurizador a placas em escala laboratorial. Contudo, no referido trabalho, os autores não computaram o efeito da letalidade e nem da incrustação do produto.

A fim de tornar a modelagem mais completa e realista, a contribuição deste trabalho é a consideração da letalidade do tratamento térmico para uma bactéria alvo e o efeito da incrustação do leite na seção de aquecimento do equipamento, bem como a validação dos históricos de temperatura, do fator de incrustação, coeficiente global de troca térmica e da massa total depositada nas placas do pasteurizador.

Antes, algumas considerações ou hipóteses são apresentadas a seguir:

i. Regime em estado transiente;

ii. Todos os fluidos (água e leite) têm comportamento newtoniano (BYLUND, 1995; FOX, MCSWEENEY, 1998), são incompressíveis e homogêneos;

iii. Sem geração de energia devido ao atrito viscoso;

iv. Temperatura da placa uniforme em sua seção transversal;

v. Temperatura do fluido uniforme na seção transversal do canal;

vi. Perdas de calor para o ambiente são desprezíveis no PHE (adiabático);

vii. Escoamento sem pontos de estagnação;

viii. Perdas de calor para o ambiente são consideradas apenas no tubo de retenção e em suas conexões;

ix. O perfil de velocidades é achatado (escoamento pistonado ou plug-flow ideal);

x. Distribuição uniforme de fluxo nos passes do PHE, considerada mistura perfeita nas saídas dos passes do trocador de calor;

xi. Para os fluidos, não há transferência de calor por difusão na direção axial;

xii. Para as placas, há transferência de calor por difusão na direção axial e elas trocam calor com os canais adjacentes por convecção;

xiii. As propriedades físicas dos fluidos são consideradas constantes e uniformes em cada seção do pasteurizador, sendo calculados os seus valores médios; 
xiv. Não há mudanças de fase no escoamento;

xv. Variações das energias potencial, cinética e outras energias não térmicas são desprezíveis nos balanços;

xvi. A resistência térmica das placas, tubos e paredes do equipamento são uniformes;

xvii. A incrustação do produto só é considerada na seção de aquecimento do equipamento uma vez que esta é a seção de maior importância em termos de transferência de energia ao produto e por estar em uma maior temperatura.

$\mathrm{Na}$ Figura 4.1 são mostrados os caminhos que os fluidos, leite e utilidades de aquecimento e resfriamento, percorrem no pasteurizador, durante o funcionamento do equipamento.

Figura 4.1 - Visão global do processo de pasteurização e seus pontos de registro de temperatura ao longo do equipamento.

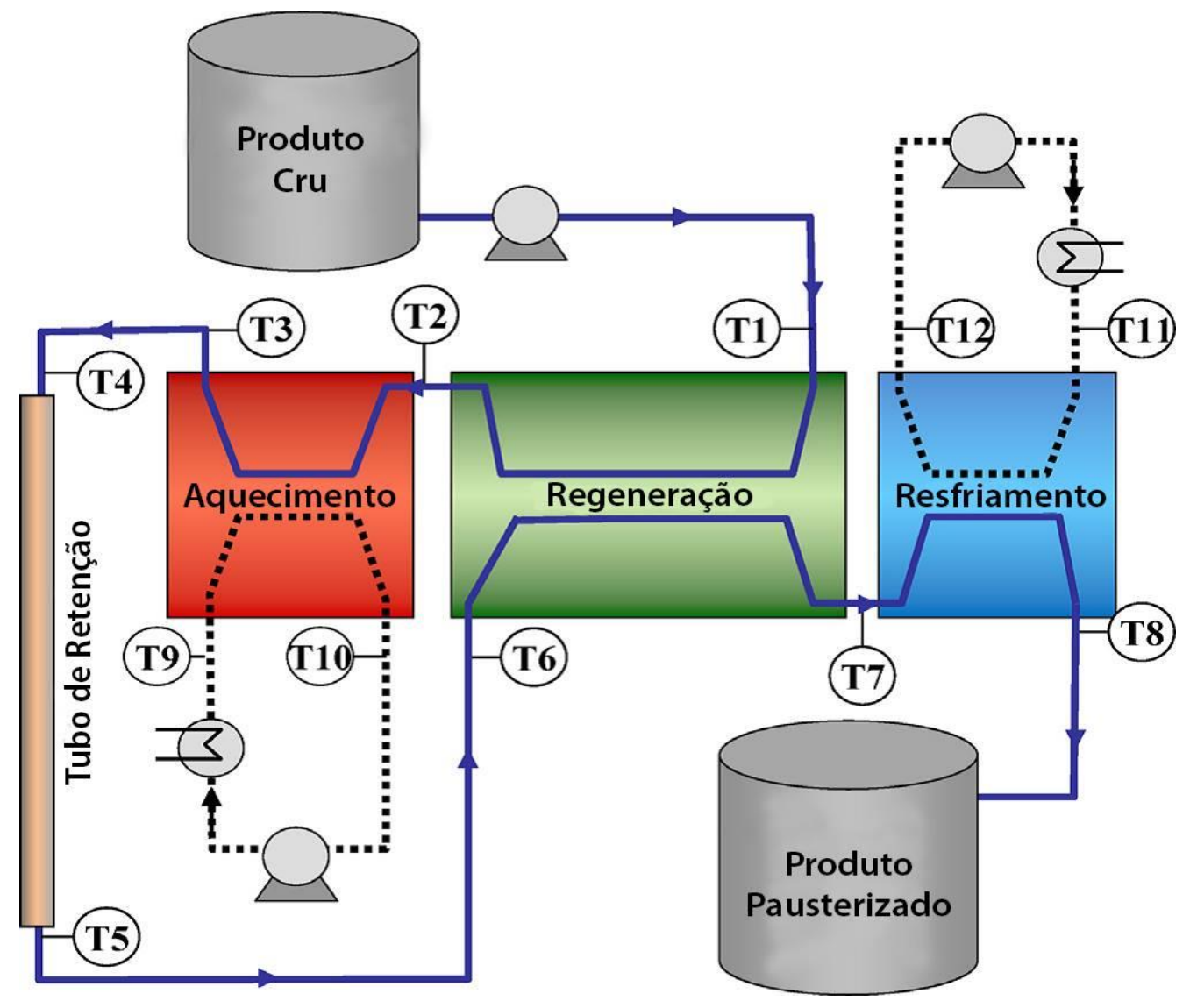

Fonte: adaptado de Gutierrez et al., 2014. 
Basicamente, o pasteurizador modelado é composto por três trocadores de calor, sendo as seções de aquecimento (heating), regeneração (regeneration) e resfriamento (cooling), e pelo tubo de retenção (holding tube) e seus trechos.

As indicações T1, T2, T3, T4, T5, T6, T7 e T8 correspondem aos pontos de registro online da temperatura do leite ao longo do processo de pasteurizador, sendo: entrada do produto cru, entrada e saída da seção de aquecimento, entrada e saída do tubo de retenção, entrada e saída da regeneração e saída do leite - já tratado - após o seu resfriamento, respectivamente. Já as indicações T9, T10, T11 e T12, representam as temperaturas de entrada e saída das utilidades de aquecimento e resfriamento, nesta mesma ordem.

A especificação "Tubo 2" refere-se ao tubo de retenção. Já as especificações "Tubo 1" e "Tubo 3" referem-se às conexões de entrada e saída, respectivamente.

Para realização da modelagem do processo é importante uma correta descrição da geometria, área de escoamento e troca térmica. Dois parâmetros importantes são considerados, sendo o diâmetro equivalente $\left(D_{e}\right)$ e o diâmetro hidráulico $\left(D_{h}\right)$ (WANG et al., 2007). Segundo Bergman et al. (2011), o diâmetro hidráulico é usado em cálculos de engenharia, para os parâmetros como Reynolds $(R e)$ e Nusselt $(\mathrm{Nu})$, por exemplo. Logo, considerar-se-á que o diâmetro equivalente do canal do PHE é o seu diâmetro hidráulico e, como $b<<w$, a expressão para o diâmetro hidráulico fica (KAKAÇ, LIU, 2002; SHAH, SEKULIC, 2003; WANG et al., 2007):

$$
D_{e}=D_{h}=\frac{4 \cdot A_{c}}{P_{w}}=\frac{4 \cdot b \cdot w}{2 \cdot(b+w \cdot \Phi)} \cong \frac{2 \cdot b}{\Phi}
$$

em que $A_{c}$ é a área da seção transversal ao escoamento, $P_{w}$ é o perímetro molhado, $b$ é a espessura média do canal, $w$ é a largura efetiva do canal e $\Phi$ representa o fator área superficial efetiva de transferência de calor ou fator de alargamento, sendo representado por (GUT, 2003; KAKAÇ, LIU, 2002; WANG et al., 2007):

$$
\Phi=\frac{\text { área desenvolvida }}{\text { área projetada }}=\frac{A_{p}}{L \cdot w} \quad \text { com } \Phi \geq 1,0
$$

em que $L$ é o comprimento útil da placa $(\mathrm{m})$. 
Geralmente a área projetada é diferente da desenvolvida $\left(A_{p}\right)$ devido às ranhuras das placas, fazendo com que a área real de troca térmica, a área desenvolvida, seja maior que a área projetada (GUT, 2003). Então, a área total de troca térmica de uma placa $\left(A_{p}\right)$ e a área de escoamento do canal entre as placas $\left(A_{c}\right)$ serão dadas por (SHAH, SEKULIC, 2003):

$$
A_{p}=\Phi \cdot L \cdot w \quad \text { e } \quad A_{c}=b \cdot w
$$

Pela inspeção da Figura 4.2, é possível observar todas as dimensões explicitadas para uma placa típica Chevron, em que $\beta$ e $L_{P}$ são o ângulo de inclinação das ranhuras e comprimento da placa entre os dois orifícios, respectivamente.

Figura 4.2 - Dimensões de uma típica placa chevron de PHE.

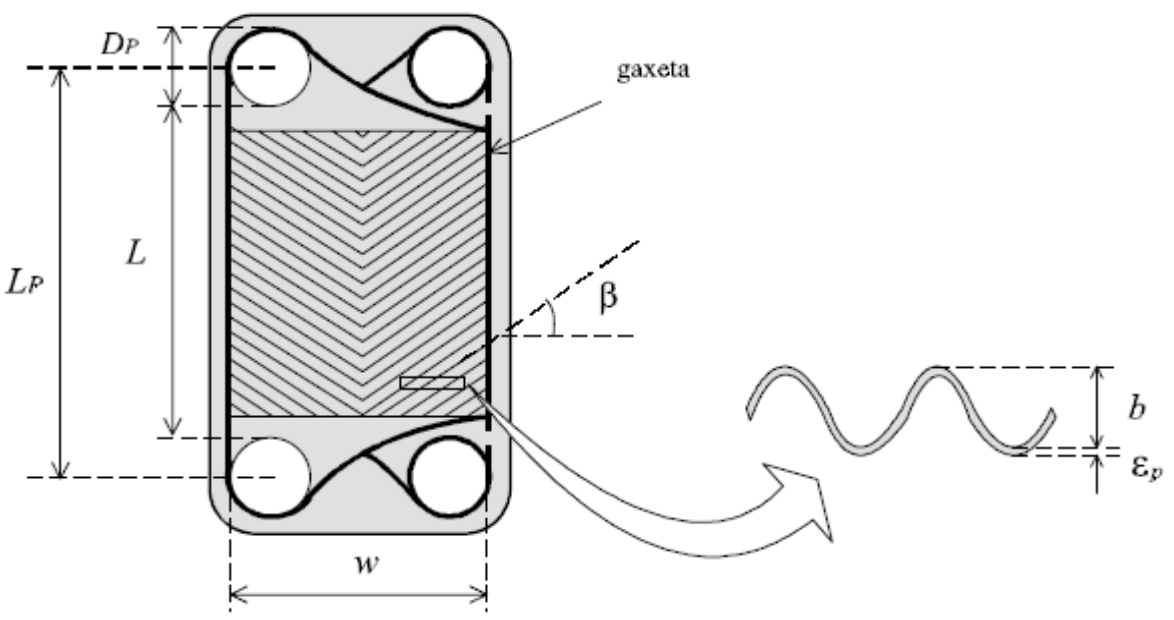

Fonte: Gut, 2003.

O número de Reynolds é um adimensional usado em problemas de escoamento, o qual representa a relação entre as forças de inércia e as forças viscosas no fluido (BERGMAN et al., 2011). Ele é definido como (SHAH, SEKULIC, 2003):

$$
R e=\frac{\rho \cdot \bar{v} \cdot D_{e}}{\mu}=\frac{G \cdot D_{e}}{\mu}
$$

em $\rho$ é a densidade média do fluido que escoa, $\mu$ é a sua viscosidade, $\bar{v}$ é a velocidade média, $D_{e}$ é o diâmetro equivalente do duto ou do trocador e $G$ é o fluxo mássico, o qual, para um PHE, é representado por (KAKAÇ, LIU, 2002; SHAH, SEKULIC, 2003): 


$$
G=\frac{\text { vazão mássica no canal do PHE }}{\text { área transversal do escoamento no canal }}=\frac{\dot{m}_{i}}{b \cdot w}=\frac{\dot{m}}{(b \cdot w \cdot N)}
$$

Outro adimensional pertinente é o número de Prandtl $(\operatorname{Pr})$, que representa o quociente entre a difusividade da quantidade de movimento e a difusividade térmica, isto é (SHAH, SEKULIC, 2003):

$$
\operatorname{Pr}=\frac{v}{\alpha_{t}}=\frac{v}{\left(\frac{k}{\rho \cdot C p}\right)}=\frac{\mu \cdot C p}{k}
$$

em que $k$ é a condutividade térmica, $C p$ é o calor específico, $v$ é a viscosidade cinemática e $\alpha_{t}$ é a difusividade térmica do fluido, sendo representada por (BERGMAN et al., 2011):

$$
\alpha_{t}=\frac{k}{\rho \cdot C p}
$$

Sabe-se que as propriedades das substâncias variam com a temperatura. Contudo, a fim de facilitar a modelagem, será feito uso das médias simples entre a entrada (ent) e saída ( $s a i$ ) de um trecho do processo, sendo isso válido para $C p, \rho, k$ e $\mu$. Por exemplo, para calor específico, tem-se:

$$
C p=\frac{C p_{e n t}+C p_{\text {sai }}}{2}
$$

Devido à transferência de calor na interface fluido-superfície, o adimensional número de Nusselt $(\mathrm{Nu})$ pode ser inserido nesta modelagem. Ele relaciona o coeficiente convectivo de calor com a condutividade térmica do fluido e o comprimento característico do escoamento, ou seja, a relação entre o fluxo de calor por convecção e o fluxo de calor por condução no fluido (SHAH, SEKULIC, 2003):

$$
N u=\frac{h \cdot D_{e}}{k}
$$


Esses adimensionais são inter-relacionados pela correlação geral (equação 4.10), a qual leva em conta diversos parâmetros de configuração do trocador, propriedades dos fluidos, geometria do canal e operação do processo (AGUIAR, GUT, 2014; GUT, 2003; KIM et al., 1999; KAKAÇ, LIU, 2002; ZHANG et al., 2013).

$$
N u=a_{1} \cdot \operatorname{Re}^{a_{2}} \cdot \operatorname{Pr}^{a_{3}} \cdot\left(\frac{\mu}{\mu_{w}}\right)^{a_{4}}
$$

em que os elementos $a_{1}, a_{2}, a_{3}$ e $a_{4}$ são parâmetros empíricos, $\mu_{w}$ é a viscosidade do fluido na temperatura média da parede e $\mu$ é a viscosidade média do fluido.

Os valores dos parâmetros $a_{1}, a_{2}, a_{3}$ e $a_{4}$ podem ser obtidos experimentalmente pelo ajuste de parâmetros empíricos (GALEAZZO et al., 2006).

A realização da modelagem será dividida nas seguintes etapas, sendo:

- Num trocador de calor a placas (uma das três seções) do pasteurizador;

- No tubo de retenção e em seus trechos de conexão aos trocadores;

- Modelagem empírica da incrustação apenas no PHE de aquecimento;

- Modelagem da letalidade nos canais dos PHEs e nos tubos do equipamento.

\subsection{Modelagem Matemática do Trocador de Calor a Placas}

O desenvolvimento dos modelos é realizando nesta seção para um trocador de calor a placas genérico, sendo que o pasteurizador possui três PHEs (Figura 4.1).

\subsubsection{Balanço de Massa para o Fluido nos Canais}

Como não há uma modelagem simples para a distribuição do fluido pelos canais do PHE com configuração genérica, é assumida a hipótese que o fluxo seja dividido igualmente entre os canais que compõe cada passe, tendo, assim, distribuição uniforme no escoamento nos canais. Portando, o lado $I$, o qual compreende o conjunto de canais de número ímpar, representa o fluido que escoa no canal $I$ e o lado $I I$, o qual compreende o conjunto de canais de número par, representa o fluido que escoa no canal II (GUT, 2003). 


$$
\begin{array}{ll}
\dot{m}_{i}=\frac{\dot{m}^{I}}{N^{I}} & \text {, se } i \text { é ímpar, canal pertence ao lado } I \\
\dot{m}_{i}=\frac{\dot{m}^{I I}}{N^{I I}} & \text {, se } i \text { é par, canal pertence ao lado } I I
\end{array}
$$

em que $N^{I}$ e $N^{I I}$ são definidos como o número de passagens (canais por passe) em cada lado do trocador.

Neste caso, será usada uma velocidade média $(\bar{v})$ para o escoamento do fluido nos canais, entre as placas do PHE. Portanto, as velocidades médias dos fluidos (água e leite), serão consideradas como:

$$
\bar{v}=\frac{\dot{m}}{N \cdot \rho \cdot b \cdot w}=\frac{\dot{V}}{N \cdot b \cdot w}
$$

em que $\dot{V}$ é a vazão volumétrica $\left(\mathrm{m}^{3} / \mathrm{s}\right)$ e $N$ é o número de canais por passe.

\subsubsection{Balanço de Energia para o Fluido nos Canais}

Os balanços de energia são elaborados de acordo com a $1^{\underline{a}}$ lei da termodinâmica (conservação da energia) para um sistema aberto (KAKAÇ, LIU, 2002; SHAH, SEKULIC, 2003). Portanto, pela Figura 4.3, aplica-se um balanço diferencial de energia no volume de controle $(V C)$, no fluido escoando em num canal genérico $(i)$ do PHE.

Neste caso, será analisada a variação de energia do fluido que está atravessando o canal pela abordagem euleriana, pois o volume de controle é fixo.

As temperaturas dos fluidos e das placas variam em relação ao espaço, nas três dimensões ( $x, y$ e $z$ ), e ao tempo. Contudo, pelas hipóteses descritas anteriormente, tem-se a análise unidimensional da transferência de energia:

$$
\frac{\partial T}{\partial z} \cong 0 \quad \text { e } \quad \frac{\partial T}{\partial y} \cong 0
$$


Então, tem-se que a temperatura $(T)$ do fluido e da placa $\left(T_{p}\right)$ são funções apenas do espaço em relação a $x$ e em relação ao tempo $(t)$.

Figura 4.3 - Volume de controle para o balanço de energia em canal genérico do PHE.

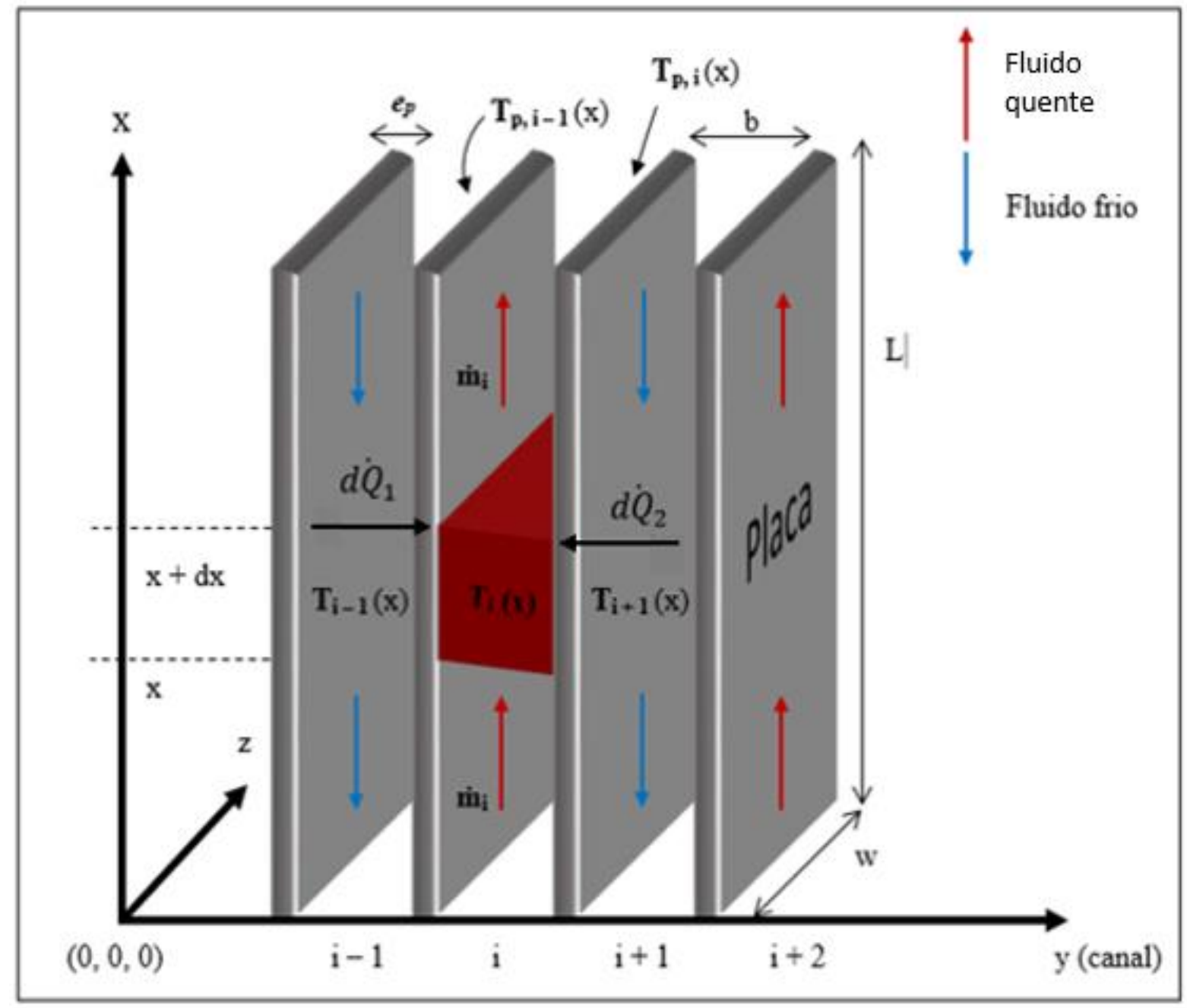

Legenda: $T_{i}$ é a temperatura do fluido no canal $i$ e $T_{p, i}$ é da placa $i$.

Fonte: elaboração do autor (2016).

Pelo balanço diferencial de energia no volume de controle no canal $i$, tem-se as parcelas de energia de entrada (ent) e saída (sai) devido ao escoamento do produto em relação ao eixo $x$, além das parcelas de energia transiente e da transferência de calor por condução e convecção (BERGMAN et al., 2011). Então, tem-se:

$$
\frac{d E}{d t}=\dot{Q}+\dot{E}_{e n t}-\dot{E}_{s a i}
$$


Detalhando as parcelas de energia total $(E)$, para um processo a pressão constante e sem trabalho de eixo, tem-se:

$$
\frac{d E}{d t}=\frac{d}{d t}\left(H+E_{C}+E_{P}\right)=\dot{Q}+\dot{E}_{\text {ent }}-\dot{E}_{\text {sai }}
$$

em que $H$ é a entalpia do sistema.

Explicitando as variações de energia devido às correntes de entrada e saída:

$$
\begin{gathered}
\frac{d}{d t}\left(H+E_{C}+E_{P}\right)=\dot{Q}+\dot{m}_{e n t} \cdot\left(\bar{H}+E_{C}+E_{P}\right)_{e n t}-\cdots \\
\cdots-\dot{m}_{\text {sai }} \cdot\left(\bar{H}+E_{C}+E_{P}\right)_{\text {sai }}
\end{gathered}
$$

em que $\bar{H}$ é a entalpia específica. Logo, pelas hipóteses já citadas, tem-se:

$$
\frac{d}{d t}(H)=\dot{Q}+\dot{m}_{e n t} \cdot(\bar{H})_{e n t}-\dot{m}_{\text {sai }} \cdot(\bar{H})_{\text {sai }}
$$

Pelo balanço de massa global no $V C, \dot{m}_{e n t}=\dot{m}_{s a i}=\dot{m}$, obtém-se:

$$
\frac{d H}{d t}=\dot{Q}+\dot{m} \cdot\left[(\bar{H})_{e n t}-(\bar{H})_{s a i}\right]
$$

Como:

$$
C p=\frac{d \bar{H}}{d T}
$$

Integrando esta equação no volume de controle para $C p$ médio:

$$
C p \cdot\left(T_{\text {ent }}-T_{\text {sai }}\right)=\left(\bar{H}_{\text {ent }}-\bar{H}_{\text {sai }}\right)
$$

Então: 


$$
C p=\frac{d \bar{H}}{d T} \quad \rightarrow \quad \frac{d H}{m}=C p \cdot d T
$$

Sabendo que $\rho=m / V$, tem-se:

$$
C p \cdot d T \cdot \rho \cdot V=d H
$$

Portanto, a equação 4.19, para um volume infinitesimal $d V$, fica igual a:

$$
\frac{(C p \cdot d T \cdot \rho \cdot d V)}{d t}=\dot{Q}+\dot{m} \cdot C p \cdot\left[T_{e n t}-T_{s a i}\right]
$$

então, aplicando ao $V C$ da Figura 4.3:

$$
\frac{\partial T_{i}}{d t} \cdot C p_{i} \cdot \rho_{i} \cdot d V=\dot{Q}+\dot{m}_{i} \cdot C p_{i} \cdot\left[T_{i}(x)-T_{i}(x+d x)\right]
$$

E, como $\dot{Q}=d \dot{Q}_{1}+d \dot{Q}_{2}$ de acordo com a Figura 4.3, tem-se:

$$
\begin{gathered}
d \dot{Q}_{1}+d \dot{Q}_{2}=d A_{p, 1} \cdot U_{i, 1} \cdot\left[T_{p, i}(x)-T_{i}(x)\right]+\cdots \\
\cdots+d A_{p, 2} \cdot U_{i, 2} \cdot\left[T_{p, i-1}(x)-T_{i}(x)\right]
\end{gathered}
$$

em que $d A_{P, 1}$ e $d A_{P, 2}$ são as áreas infinitesimais de troca nas placas 1 e 2 e $U_{i, 1}$ e $U_{i, 2}$ são os coeficientes de transferência de calor entre o centro de um canal e o centro da placa 1 ou da placa 2, respectivamente.

Rearranjando a equação 4.25 , e como $U_{i, 1}=U_{i, 2}=U_{i}$, tem-se:

$$
\begin{gathered}
\frac{\partial T_{i}}{d t} \cdot C p_{i} \cdot \rho_{i} \cdot d V=d A_{p} \cdot U_{i} \cdot\left\{\left[T_{p, i}(x)-T_{i}(x)\right]+\left[T_{p, i-1}(x)-T_{i}(x)\right]\right\}+\cdots \\
\cdots+\dot{m}_{i} \cdot C p_{i} \cdot\left[T_{i}(x)-T_{i}(x+d x)\right]
\end{gathered}
$$

em que $d V$ é o volume infinitesimal do canal. Sendo:

$$
d A_{P}=w \cdot d x \cdot \Phi \quad \text { e } \quad d V=w \cdot d x \cdot b
$$


O coeficiente global de transferência de calor $(U)$ para trocador de calor a placas em geral é composto por três parcelas: condução através da placa, convecção no fluido quente e convecção no fluido frio (BERGMAN et al., 2011; KAKAÇ, LIU, 2002; KREITH et al., 2010). Isto é:

$$
U=\frac{1}{R_{t}}=\frac{1}{R_{h, c}}+\frac{1}{R_{k}}+\frac{1}{R_{h, h}}=\frac{1}{\frac{1}{h_{c}}+\frac{e_{p}}{k_{p}}+\frac{1}{h_{h}}}
$$

em que $R_{t}$ é a resistência térmica total de transferência de calor $\left(\mathrm{m}^{2} \mathrm{~K} / \mathrm{W}\right), R_{h, c}, R_{h, h} \mathrm{e}$ $R_{k}$, representam as resistências devido à transferência de calor convectiva no lado frio, $c$ (cold), e quente, $h$ (hot), do trocador e a resistência térmica condutiva da placa, respectivamente. $h_{c}$ e $h_{h}$ são os coeficientes de troca térmica convectivo nas superfícies do lado frio e do quente das placas $\left(\mathrm{W} / \mathrm{m}^{2} . \mathrm{K}\right), k_{p}$ é a condutividade térmica da placa $(\mathrm{W} / \mathrm{m} . \mathrm{K})$ e $e_{p}$ é a sua espessura $(\mathrm{m})$.

Porém, modelando do plano central do canal até o central da placa adjacente, e sem levar em conta o efeito da incrustação, tem-se:

$$
\frac{1}{U_{i}}=\frac{1}{h_{i}}+\frac{e_{p} / 2}{k_{p}}
$$

Sabe-se que o coeficiente global de troca térmica no canal $\left(U_{i}\right)$ varia ao longo do escoamento devido uma série de fatores, tanto do fluido como do próprio escoamento (BERGMAN et al., 2011). Contudo, como é adotada a hipótese de propriedades uniformes e constantes (valores médios para os fluidos), é razoável considerar que o coeficiente global de transmissão de calor seja constante no PHE (GUT, 2003).

Como há uma distribuição transversal uniforme de temperatura (considerações anteriores), a temperatura no canal do PHE pode ser considerada como função de seu comprimento adimensional, $\eta$. Portanto, para fins de cálculo, é feita a adimensionalização do comprimento do canal $(x)$ da seguinte forma (GUT, 2003):

$$
\eta=\frac{x}{L} \quad \text {, sendo que } 0,0 \leq \eta \leq 1,0
$$


Além disso, nomeando as novas variáveis auxiliares da modelagem, tempo espacial no canal $\left(\tau_{i}\right)$ e o coeficiente $\alpha_{i}$, em um canal genérico $i$, tem-se:

$$
\tau_{i}=\frac{b \cdot \rho_{i} \cdot w \cdot L}{\dot{m}_{i}}=\frac{L}{\bar{v}_{i}} \quad \text { e } \quad \alpha_{i}=\frac{w \cdot L \cdot \Phi}{\dot{m}_{i} \cdot C p_{i}}
$$

Em PHEs emprega-se o parâmetro binário $Y_{h}$, o qual descreve a localização dos fluidos quente e frio nos lados I e II do trocador. Quando o fluido quente preenche o lado I tem-se $Y_{h}=1$ e se o fluido frio preencher o lado II, então o valor designado para este será $Y_{h}=0$ (GUT, 2003). Isso é representado esquematicamente na Figura 4.4.

Figura 4.4 - Parâmetro de configuração do PHE genérico em relação à localização dos fluidos quente e frio.

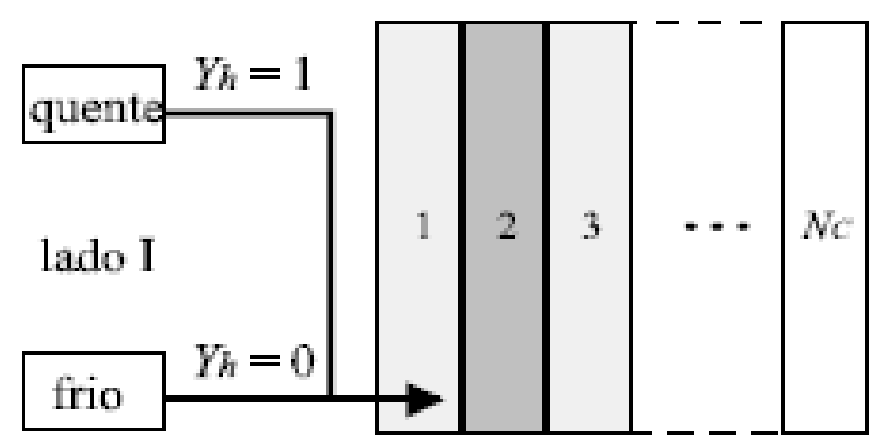

Fonte: adaptado de Gut e Pinto (2009).

Nesse sentido, considerando as equações 4.11 e 4.12, para os dois lados, quente e frio, ( $I$ e $I I)$ do trocador, tem-se:

$$
\alpha^{I}=\frac{w \cdot L \cdot \Phi \cdot N^{I}}{\dot{m}^{I} \cdot C p^{I}} \quad \text { e } \quad \alpha^{I I}=\frac{w \cdot L \cdot \Phi \cdot N^{I I}}{\dot{m}^{I I} \cdot C p^{I I}}
$$

Além disso, para os dois lados (I e II) do PHE, tem-se:

$$
\tau^{I}=\frac{b \cdot \rho_{i} \cdot w \cdot L \cdot N^{I}}{\dot{m}^{I}}=\frac{L}{\bar{v}^{I}} \quad \text { e } \quad \tau^{I I}=\frac{b \cdot \rho_{i} \cdot w \cdot L \cdot N^{I}}{\dot{m}^{I I}}=\frac{L}{\bar{v}^{I I}}
$$

Adimensionalizando as variações infinitesimais: 


$$
d x=d(\eta \cdot L) \quad \rightarrow \quad d x=d \eta \cdot L
$$

Inserindo na equação 4.27 , dividindo tudo pela vazão no canal $\left(\dot{m}_{i}\right)$ e por $C p_{i}$, e rearranjando, tem-se:

$$
\begin{gathered}
\frac{\partial T_{i}}{\partial t} \cdot \tau_{i}=\alpha_{i} \cdot U_{i} \cdot\left[-2 \cdot T_{i}(\eta)+T_{p, i}(\eta)+T_{p, i-1}(\eta)\right]+\cdots \\
\cdots+\frac{\left[T_{i}(\eta)-T_{i}(\eta+d \eta)\right]}{d \eta}
\end{gathered}
$$

Além disso, é introduzido um parâmetro para descrever o sentido do escoamento do fluido nos canais:

$S_{i}=+1 \rightarrow$ escoamento no canal é no sentido positivo de $x$; ou

$S_{i}=-1 \rightarrow$ escoamento no canal é no sentido negativo de $x$.

Outrossim, como $\frac{\left[T_{i}(\eta)-T_{i}(\eta+d \eta)\right]}{d \eta}$ representa o negativo da variação da temperatura em relação a $\eta$ (derivada parcial), então, tem-se:

$$
\frac{\partial T_{i}}{\partial t} \cdot \tau_{i}+\frac{\partial T_{i}}{\partial \eta} \cdot S_{i}=\alpha_{i} \cdot U_{i} \cdot\left[-2 \cdot T_{i}(\eta)+T_{p, i}(\eta)+T_{p, i-1}(\eta)\right]
$$

sendo que o contador $i$ vai de 1 até $N c$, para $N c=$ número de canais, e que $U_{i}$ é o coeficiente global médio de transferência de calor, como dito anteriormente, entre o centro do canal, no volume de controle, até o centro da placa adjacente.

Sabe-se que o primeiro e o último canal só trocam calor para um dos lados. Mediante isso, para o primeiro e último canal, respectivamente, tem-se:

$$
\begin{gathered}
\frac{\partial T_{1}}{\partial t} \cdot \tau_{1}+\frac{\partial T_{1}}{\partial \eta} \cdot S_{1}=\alpha_{1} \cdot U_{1} \cdot\left[-T_{1}(\eta)+T_{p, 1}(\eta)\right] \\
\frac{\partial T_{N c}}{\partial t} \cdot \tau_{N c}+\frac{\partial T_{N c}}{\partial \eta} \cdot S_{N c}=\alpha_{N c} \cdot U_{N c} \cdot\left[-T_{N c}(\eta)+T_{p, N c-1}(\eta)\right]
\end{gathered}
$$


Já um canal interno $i$, que troca calor com ambos os lados, se $i$ for ímpar (I):

$$
\frac{\partial T_{i}}{\partial t} \cdot \tau_{i}+\frac{\partial T_{i}}{\partial \eta} \cdot S_{i}=\alpha_{i}^{I} \cdot U_{i}^{I} \cdot\left[-2 \cdot T_{i}(\eta)+T_{p, i}(\eta)+T_{p, i-1}(\eta)\right]
$$

E para um canal interno $i$, se $i$ for par $(I I)$ :

$$
\frac{\partial T_{i}}{\partial t} \cdot \tau_{i}+\frac{\partial T_{i}}{\partial \eta} \cdot S_{i}=\alpha_{i}^{I I} \cdot U_{i}^{I I} \cdot\left[-2 \cdot T_{i}(\eta)+T_{p, i}(\eta)+T_{p, i-1}(\eta)\right]
$$

Os modelos obtidos acima são similares aos encontrados por Khan e Rahman (2012) em trabalho de modelagem e simulação dinâmica, em um PHE, o qual também foi considerado escoamento pistonado.

\subsubsection{Balanço de Energia para as Placas}

Pela Figura 4.5 observa-se a aplicação do balanço diferencial de energia numa placa genérica $i$ do PHE, com um volume de controle $(V C)$.

Figura 4.5 - Volume de controle para balanço de energia em placa genérica do PHE.

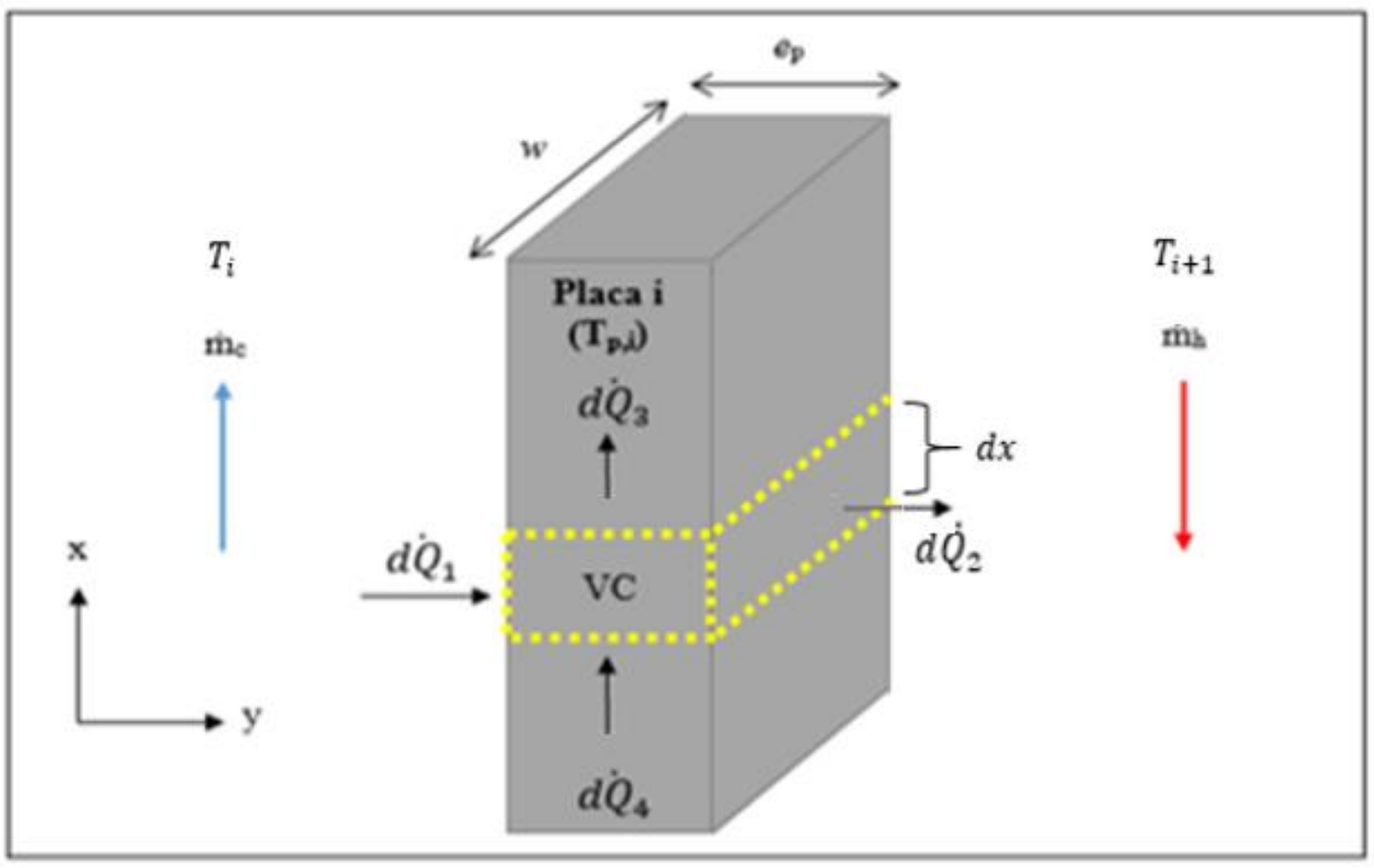

Fonte: elaboração do autor (2016). 
Similarmente ao caso anterior, pela análise no $V C$, tem-se:

$$
\frac{d H}{d t}=d \dot{Q}_{1}-\dot{d Q_{2}}-d \dot{Q}_{3}+\dot{d} Q_{4}
$$

Há difusão de calor pela placa (meio sólido): $d \dot{Q}_{3}$ e $\dot{d Q_{4}}$. Então, faz-se uso da lei de Fourier, a qual estabelece que o fluxo de calor $(\dot{q})$ é equivalente ao gradiente de temperatura no espaço $(\nabla \mathrm{T})$ e à condutividade térmica do material $(k)$, como mostrado pela equação 4.43 (BERGMAN et al., 2011):

$$
\dot{q}=\frac{\dot{Q}}{A}=-k \cdot \nabla \mathrm{T}
$$

Portanto, pelas condições já explicitadas anteriormente, tem-se:

$$
\begin{gathered}
\frac{\partial T_{p, i}}{d t} \cdot C p_{p} \cdot \rho_{p} \cdot d V_{p}=d A_{p} \cdot U_{i} \cdot\left[-T_{p, i}(x)+T_{i}(x)\right]+\cdots \\
\cdots+d A_{p} \cdot U_{i+1} \cdot\left[T_{i+1}(x)-T_{p, i}(x)\right]-\left.k_{p} \cdot A_{t p} \cdot \frac{\partial T_{p, i}}{\partial x}\right|_{x}+\cdots \\
\cdots+\left.k_{p} \cdot A_{t p} \cdot \frac{\partial T_{p, i}}{\partial x}\right|_{x+d x}
\end{gathered}
$$

em que $C p_{p}$ é o calor específico médio da placa, $\rho_{p}$ é a sua densidade média, $k_{p}$ é a sua condutividade térmica média, $d V_{p}$ é o volume infinitesimal dela e $A_{t p}$ é a área da secção transversal da placa, os quais equivalem a:

$$
A_{t p}=w \cdot e_{p} \quad \text { e } \quad d V_{p}=w \cdot d x \cdot e_{p}
$$

Neste caso, como $U_{i} \neq U_{i+1}$, pois circulam fluidos diferentes em cada um dos lados das placas, e as áreas de ambos os lados são iguais, tem-se:

$$
\begin{gathered}
\frac{\partial T_{p, i}}{d t} \cdot C p_{p} \cdot \rho_{p} \cdot d V_{p}=d A_{p} \cdot U_{i} \cdot\left[-T_{p, i}(x)+T_{i}(x)\right]+\cdots \\
\cdots+U_{i+1} \cdot\left[T_{i+1}(x)-T_{p, i}(x)\right]
\end{gathered}
$$




$$
\cdots+k_{p} \cdot A_{t p} \cdot\left(\left.\frac{\partial T_{p, i}}{\partial x}\right|_{x+d x}-\left.\frac{\partial T_{p, i}}{\partial x}\right|_{x}\right)
$$

Ainda, pela adimensionalização da direção $x$ (para $L$ ) e rearranjando os termos da equação, ter-se-á:

$$
\begin{gathered}
\frac{\partial T_{p, i}}{d t} \cdot \frac{C p_{p} \cdot \rho_{p} \cdot L^{2}}{k_{P}}=\frac{L^{2} \cdot \Phi}{k_{p} \cdot e_{p}} \cdot \cdots \\
\cdots \cdot\left\{U_{i} \cdot\left[-T_{p, i}(\eta)+T_{i}(\eta)\right]+U_{i+2} \cdot\left[T_{i+1}(\eta)-T_{p, i}(\eta)\right]\right\}+\cdots \\
\cdots+\frac{1}{\partial \eta} \cdot\left(\left.\frac{\partial T_{p, i}}{\partial \eta}\right|_{\eta+d \eta}-\left.\frac{\partial T_{p, i}}{\partial \eta}\right|_{\eta}\right)
\end{gathered}
$$

Pela definição de derivada segunda, tem-se que:

$$
\frac{1}{\partial \eta} \cdot\left(\left.\frac{\partial T_{p, i}}{\partial \eta}\right|_{\eta+d \eta}-\left.\frac{\partial T_{p, i}}{\partial \eta}\right|_{\eta}\right)=\frac{\partial^{2} T_{p, i}}{\partial \eta^{2}}
$$

Substituindo a difusividade térmica da placa, $\alpha_{p}$, e nomeando as variáveis auxiliares da modelagem, $J_{P}$ (s) e $\varpi$ (coeficiente), tem-se:

$$
J_{P}=\frac{L^{2}}{\alpha_{p}} \quad \quad \quad \text { e } \quad \varpi=\frac{L^{2} \cdot \Phi}{k_{P} \cdot e_{p}}
$$

Finalmente, chega-se à equação diferencial 4.50:

$$
\begin{gathered}
\frac{\partial T_{p, i}}{d t} \cdot J_{P}-\frac{\partial^{2} T_{p, i}}{\partial \eta^{2}}=\varpi \cdot\left\{U_{i} \cdot\left[-T_{p, i}(\eta)+T_{i}(\eta)\right]+\cdots\right. \\
\left.\cdots+U_{i+1} \cdot\left[T_{i+1}(\eta)-T_{p, i}(\eta)\right]\right\}
\end{gathered}
$$

Portanto, o balanço de energia diferencial numa placa genérica, se $i$ for ímpar (4.51) e se $i$ for par (4.52), será, respectivamente: 


$$
\begin{gathered}
\frac{\partial T_{p, i}}{d t} \cdot J_{P}-\frac{\partial^{2} T_{p, i}}{\partial \eta^{2}}=\varpi \cdot\left\{U^{I} \cdot\left[-T_{p, i}(\eta)+T_{i}(\eta)\right]+\cdots\right. \\
\left.\cdots+U^{I I} \cdot\left[T_{i+1}(\eta)-T_{p, i}(\eta)\right]\right\} \\
\frac{\partial T_{p, i}}{d t} \cdot J_{P}-\frac{\partial^{2} T_{p, i}}{\partial \eta^{2}}=\varpi \cdot\left\{U^{I I} \cdot\left[-T_{p, i}(\eta)+T_{i}(\eta)\right]+\cdots\right. \\
\left.\cdots+U^{I} \cdot\left[T_{i+1}(\eta)-T_{p, i}(\eta)\right]\right\}
\end{gathered}
$$

Essas equações representam a modelagem matemática devido ao balanço de energia diferencial nas placas dos PHEs do pasteurizador.

\subsubsection{Modelagem da Letalidade nos Canais do PHE}

Na realização da modelagem dinâmica da letalidade, nos canais do PHE, será considerada que a destruição do indicador alvo seja uma reação química de cinética de 1aㅡordem, isto é (DE JONG, 2008; MAROULIS, SARAVACOS, 2003):

$$
r_{A}=-k_{A} \cdot C_{A}
$$

em que $k_{A}$ é a constante cinética [1/s], $r_{A}$ é a velocidade de reação de inativação microbiológica [UFC $/ \mathrm{m}^{3}$.s] e $C_{A}$ é a concentração do micro-organismo alvo [UFC/m³].

Aplicando um balanço diferencial material microbiano, para $A$ (bactéria-alvo), no $V C$ do canal $i$ de um PHE (Figura 4.3), em estado transiente, tem-se (FOGLER, 1999):

$$
\dot{n}_{e n t, A}-\dot{n}_{s a i, A}+\dot{R}_{G, A}-\dot{R}_{C, A}=\frac{d n_{A}}{d t}
$$

em que $\dot{n}_{e, A}$ e $\dot{n}_{s, A}$ representam as taxas materiais (UFC/s) de entrada e saída do alvo $A$, respectivamente, no volume de controle $(V C)$, e $\dot{R}_{G, A}$ e $\dot{R}_{C, A}$ referem-se às taxas de geração e consumo de $A$, no volume de controle, devido à reação química. Então, para um canal genérico $i$ do PHE, tem-se:

$$
\dot{V}_{i} \cdot\left(C_{A, e n t}-C_{A, s a i}\right)-r_{A} \cdot d V=\frac{\partial\left(C_{A, i} \cdot V\right)}{\partial t}
$$




$$
\dot{V}_{i} \cdot\left(-\partial C_{A, i}\right)-k_{A} \cdot C_{A, i} \cdot\left(A_{c} \cdot d x\right)=\frac{\partial C_{A, i}}{\partial t} \cdot\left(A_{c} \cdot d x\right)
$$

Dividindo ambos os lados da equação por $A_{c} \cdot d x$, tem-se:

$$
\begin{aligned}
& -\frac{\dot{V}_{i}}{A_{c}} \cdot\left(\frac{\partial C_{A, i}}{\partial x}\right)-k_{A} \cdot C_{A, i}=\frac{\partial C_{A, i}}{\partial t} \\
& -\bar{v}_{i} \cdot\left(\frac{\partial C_{A, i}}{\partial x}\right)-k_{A} \cdot C_{A, i}=\frac{\partial C_{A, i}}{\partial t}
\end{aligned}
$$

sendo $\bar{v}_{i}$ a velocidade média do escoamento no canal [m/s] e $A_{c}\left[\mathrm{~m}^{2}\right]$ a área da seção transversal do escoamento.

O parâmetro cinético $D$ é relacionado com $k_{A}$ pela equação 4.59 (GAVA, 2007):

$$
k_{A}=\frac{\ln 10}{D}=\frac{2,3026}{D}
$$

A temperatura do processo afeta significativamente o valor de $D$ da destruição do indicador alvo. Neste sentido, a equação 4.60 mostra esta relação (BALL, OLSON, 1957; PFLUG, 1990).

$$
\frac{D(T)}{D_{r e f}}=10\left(\frac{T_{r e f}-T}{z}\right)
$$

Novamente, usando a forma adimensionalizada de $x$, explicitando o sentido do escoamento e substituindo as equações, para $1 \leq i \leq N c$, tem-se:

$$
\frac{\partial C_{A, i}}{\partial \eta}=-\frac{L}{\bar{v}_{i}} \cdot\left[\frac{\partial C_{A, i}}{\partial t}+\left(\frac{2,3026 \cdot C_{A, i}(\eta, t)}{D_{r e f} \cdot 10^{\left(\frac{T_{r e f}-T}{z}\right)}}\right)\right]
$$

Para as seções de aquecimento e resfriamento, $i$ só assume valores referentes aos canais em que escoa o leite e para a seção de regeneração assume valores pares e ímpares, pois os dois lados do PHE têm produto. 
Além disso, é computado o tempo espacial que o fluido permanece no canal do PHE durante a sua operação. Para este caso, em escoamento pistonado ideal e com densidade constante ao longo do tempo, o tempo médio de residência teórico ou tempo espacial nos canais do $\operatorname{PHE}\left(\tau_{i}\right)$ é definido como a razão entre o volume interno do sistema $(V)$ e a vazão volumétrica $(\dot{V})$ (FOGLER, 1999; GUT, 2012), conforme equação 4.34 .

$$
\tau_{i}=\frac{V}{\dot{V}}=\frac{A_{c} \cdot L}{A_{c} \cdot \bar{v}_{i}}=\frac{L}{\bar{v}_{i}}
$$

Portanto, substituindo na equação e a rearranjando, tem-se:

$$
\tau_{i} \cdot \frac{\partial C_{A, i}}{\partial t}+\frac{\partial C_{A, i}}{\partial \eta} \cdot S_{i}=-\left[\tau_{i} \cdot\left(\frac{2,3026 \cdot C_{A, i}(\eta, t)}{D_{r e f} \cdot 10^{\left(\frac{T_{r e f}-T}{z}\right)}}\right)\right]
$$

Contudo esta representação é uma aproximação da realidade devido às zonas de estagnação e recirculação nos canais do PHE (BENZE, 2013; GUT, 2012). Outra maneira de se representar o escoamento nos canais do trocador é pela substituição do tempo espacial $(\tau)$ pelo tempo médio de residência $\left(t_{m}\right)$, o qual é determinado experimentalmente, sendo que: $t_{m}<\tau$ (GUT, 2012; LEVENSPIEL, 2007).

Outra variável que deve ser utilizada nesta análise é o valor de esterilização ou decaimento logarítmico decimal da concentração $(S V)$ do indicador alvo durante o processamento do leite. Ele é usado para avaliar a eficiência e a letalidade alcançada no processo térmico (GAVA, 2007; GUT, 2012; LEWIS, HEPPELL, 2000). Logo:

$$
S V=\log \left(\frac{C_{A, 0}}{C_{A}}\right)
$$

em que $C_{A, 0}$ e $C_{A}$ representam as concentrações de alimentação e de saída, para o elemento em estudo, ao longo do processo, respectivamente.

Essas equações representam a modelagem matemática devido ao balanço material do indicador alvo, neste caso, micro-organismos, nos canais dos PHEs do pasteurizador. 


\subsubsection{Modelagem da Incrustação nos Canais}

O efeito da incrustação do leite no equipamento, ao longo de sua pasteurização, será considerado apenas na seção de aquecimento, uma vez que este fenômeno é mais significativo nesta parte do pasteurizador, devido à maior temperatura do produto nesta etapa do processo, e pelo contato direto entre o leite e as placas quentes, e também pelo fato de ser a única seção a qual a taxa de recebimento de calor é crítica, diferente da seção de resfriamento, por exemplo, que não é responsável por fornecer energia térmica a fim de garantir a inocuidade do produto final. Além disso, no PHE da seção de aquecimento, é considerado o fenômeno da incrustação apenas nos canais que escoam leite, já que nos outros canais circulam apenas água limpa.

A incrustação causa mudança no coeficiente global de transferência de calor $(U)$, ou seja, ocorre o acréscimo de um termo a mais na equação do coeficiente global de transferência de calor entre o fluido e a superfície térmica. Então, de acordo com Changani et al. (1997), tem-se:

$$
\frac{1}{U_{t}}=\frac{1}{U}+R_{f}
$$

em que $U_{t}\left(\mathrm{~W} / \mathrm{m}^{2} . \mathrm{K}\right)$ é o coeficiente global total de transferência de calor, considerando o fenômeno da incrustação (equipamento sujo), $R_{f}\left(\mathrm{~K} \cdot \mathrm{m}^{2} / \mathrm{W}\right)$ é a resistência térmica da incrustação ou fator de incrustação e $U$ é o coeficiente global total de transferência de calor $\left(\mathrm{W} / \mathrm{m}^{2} \mathrm{~K}\right)$ do equipamento limpo.

O coeficiente global total de transferência de calor $\left(U_{t}\right)$, considerando as trocas de calor entre a utilidade de aquecimento e o leite a pasteurizar, sujeito à incrustação, fica (BERGMAN, et al., 2011; FRYER, SLATER, 1985; KAKAÇ, LIU, 2002):

$$
U_{t}=\frac{1}{R_{t}}=\frac{1}{R_{h, c}}+\frac{1}{R_{k}}+\frac{1}{R_{h, h}}+\frac{1}{R_{f}}=\frac{1}{\frac{1}{h_{c}}+\frac{e_{p}}{k}+\frac{1}{h_{h}}+\frac{e_{f}}{k_{f}}}
$$

em que $e_{f}$ e $k_{f}$ representam a espessura média do material depositado $(\mathrm{m})$ ao longo da pasteurização do leite e a condutividade térmica média do material aderido (W/m.K) nas placas do PHE. 
Na Figura 4.6 é observada a distribuição esquemática da temperatura da utilidade de aquecimento, leite e placa do PHE para um canal genérico, ilustrando todas as parcelas dos coeficientes térmicos devido à convecção e condução de calor, levando em conta o termo do fator de incrustação do leite na placa do PHE.

Figura 4.6 - Distribuição da temperatura da água, placa, depósito e leite em uma parte qualquer do PHE na seção de aquecimento do equipamento.

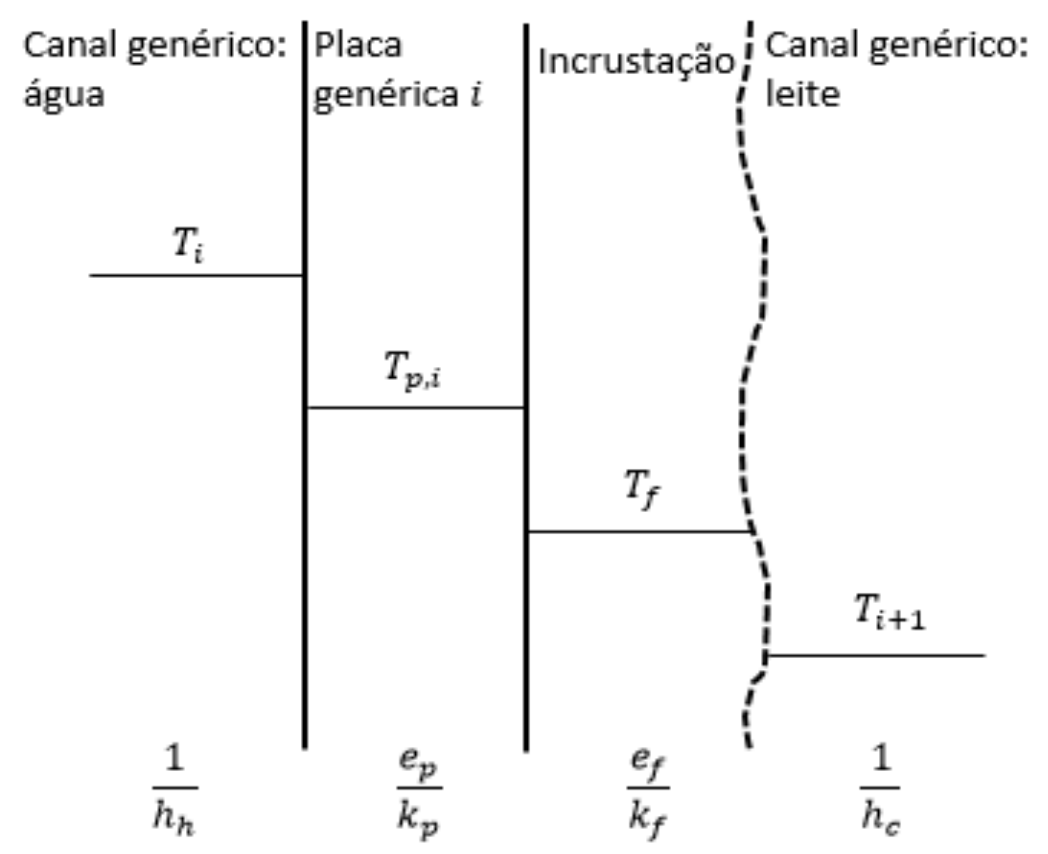

Fonte: adaptado de Fryer e Slater, 1985 e Kakaç e Liu, 2002.

Para realização da modelagem da incrustação, é considerado um modelo matemático empírico. Nesse sentido, a Figura 4.7 ilustra os principais tipos de curvas de representação do fator de incrustação ao longo do tempo, sendo: a) modelo linear; b) modelo de queda; c) modelo assintótico; d) modelo dente de serra.

Para a modelagem da incrustação do produto no equipamento, neste referido trabalho, toma-se como base a curva de modelo assintótico (c), uma vez que é a mais difundida na literatura científica.

Além disso, como o processo térmico investigado neste trabalho foi conduzido para temperaturas abaixo de $100^{\circ} \mathrm{C}$, considera-se que o fenômeno da incrustação do leite no PHE de aquecimento seja do tipo $A$, sendo, então, predominantemente proteico. 
Figura 4.7 - Curvas típicas do fator de incrustação em função do tempo de processo.

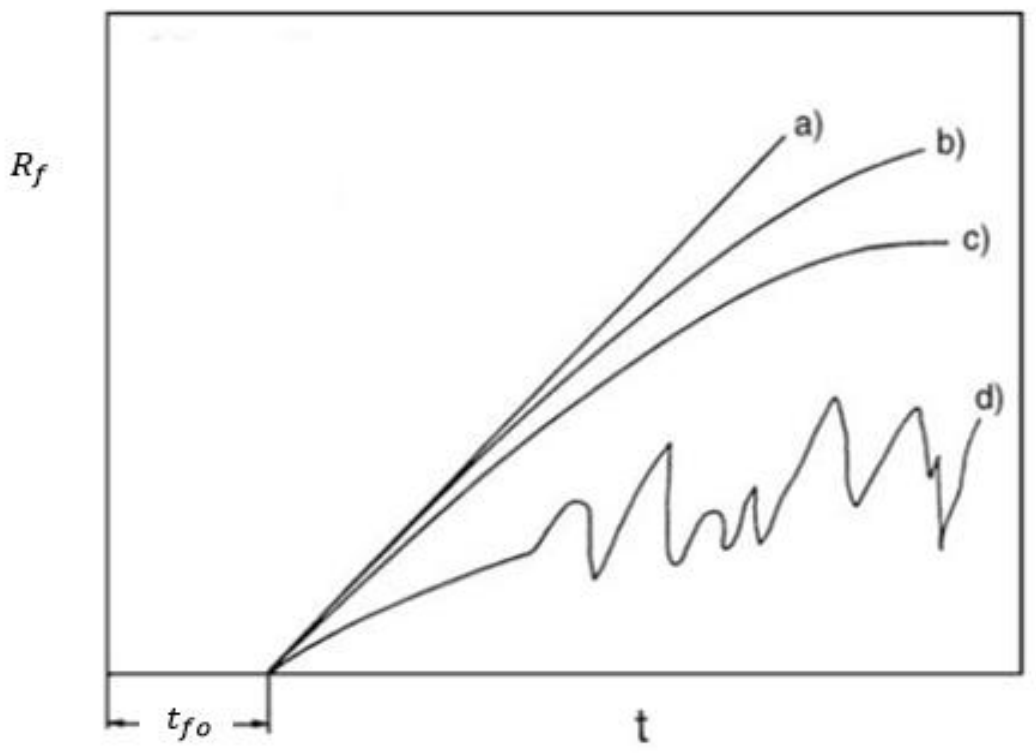

Fonte: adaptado de Bott; 1995; Changani et al., 1997; Kern e Seaton, 1959.

Tomando como ponto de partida o modelo representado pela curva c, tem-se a correlação de incrustação assintótica de acordo com Bott (1995) e Gutierrez (2013):

$$
R_{f}(t)=R_{M a x} \cdot\left(\frac{t_{f}}{\alpha_{f}+t_{f}}\right)
$$

sendo que:

$$
t_{f}=t-t_{f o} \quad \text { para } \quad t \geq t_{f}
$$

em que $R_{\text {Max }}$ é o valor máximo (assintótico) do fator de incrustação do processo, $t$ é o tempo de pasteurização (s), $t_{f o}$ é o período de indução da deposição no equipamento (s), $t_{f}$ é o tempo de incrustração do processo e $\alpha_{f}$ é o parâmetro de inclinação da curva de tendência da incrustação (s).

Consequentemente, o coeficiente global total de transferência de calor $\left(U_{t}\right)$, que é função do fator de incrustação $\left(R_{f}\right)$, dependerá do tempo de processo.

Além disso, para este tipo de modelo empírico, não se tem informações relevantes como influência da temperatura do processo, velocidade do escoamento e propriedades intrínsecas do leite, pressão de trabalho, incrustação por placa individual 
e espaço (GEOGIARDIS, MACCHIETTO, 2000). Embora estes dados sejam importantes para o entendimento completo do processo bem como uma robusta modelagem, optou-se um por modelo empírico, pois torna a modelagem menos dispendiosa, simples e de mais fácil aplicação.

De modo contrário, para o caso de modelagem fenomenológica da incrustação do leite bovino, considera-se que a incrustação do produto durante a sua pasteurização ocorre, simultaneamente, devido à transferência de massa e à reação química (BANSAL, CHEN, 2006; BELMAR-BEINY et al., 1993). Com este tipo de modelo é possível considerar as informações negligenciadas no caso anterior, sendo, então, esta uma opção de investigação mais completa, só que mais complexa.

\subsection{Modelagem do Tubo de Retenção e suas Conexões}

Na Figura 4.8 é possível observar uma representação de uma parte do tubo de retenção bem como o volume de controle $(V C)$ ao qual será aplicado o balanço de energia diferencial, sendo indicada a direção do escoamento do leite. Da mesma forma que para os canais do PHE, será feita também a observação euleriana.

\subsubsection{Balanço de Energia para o Fluido nos Tubos}

Repetindo-se o procedimento de análise de um $V C$ no canal do PHE (seção 4.1.2), só que para o tubo de retenção, tem-se o balanço diferencial de energia dado pela Figura 4.8.

A temperatura do fluido no tubo varia em relação ao espaço e ao tempo, isto é $T(x, r, \theta, t)$. Contudo, pelas hipóteses já explicitadas anteriormente, tem-se que:

$$
\frac{\partial T}{\partial \theta} \cong 0 \quad \frac{\partial T}{\partial r} \cong 0
$$

Portanto, tem-se $T(x, t)$. Então, de modo similar a modelagem dos canais dos PHEs do pasteurizador, sem trabalho de eixo, tem-se a equação 4.70. 
Figura 4.8 - Volume de controle $(V C)$ para balanço de energia diferencial no tubo de retenção e em seus trechos.

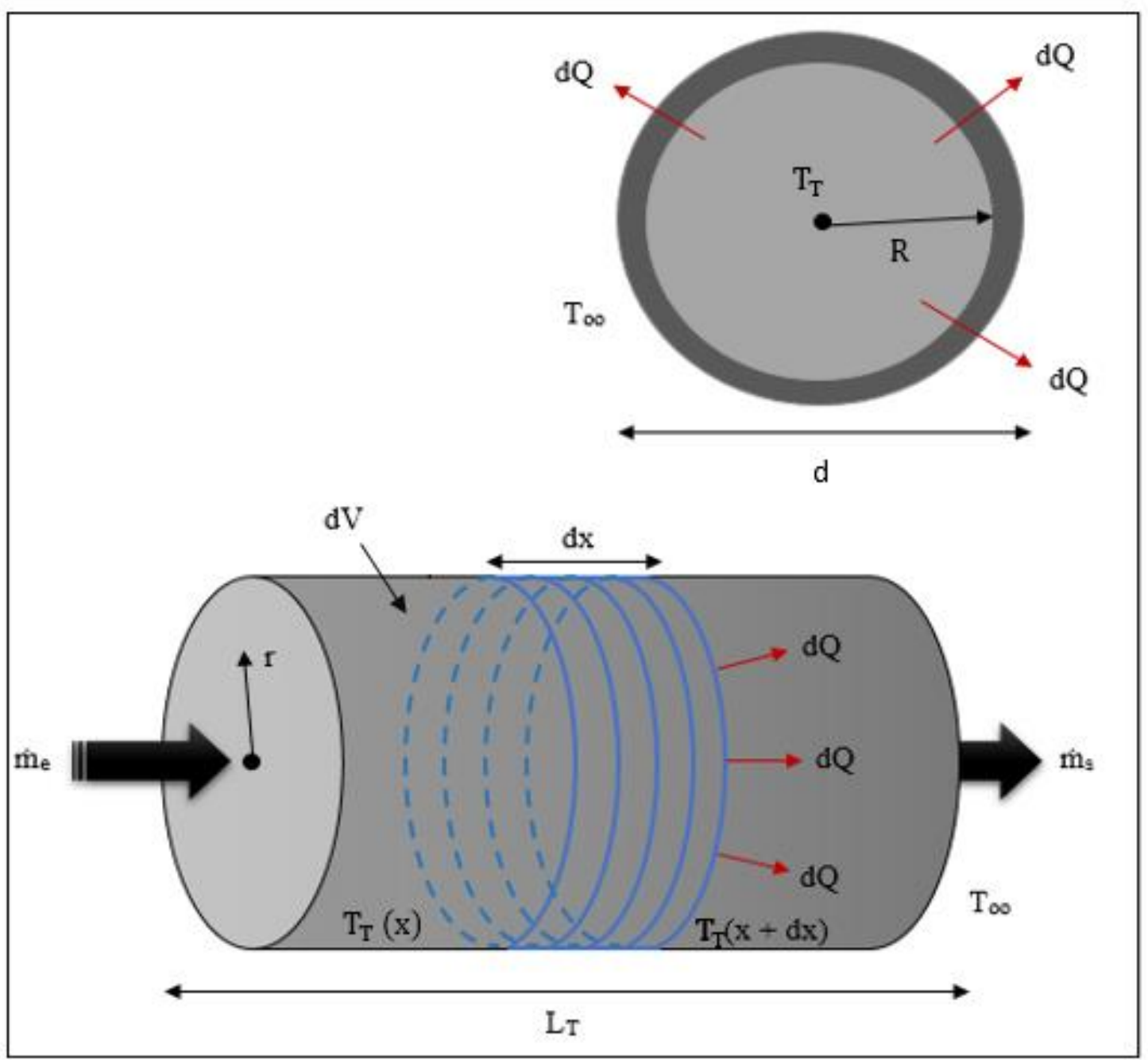

Fonte: elaboração do autor (2016).

Isto é:

$$
\begin{gathered}
\frac{d E}{d t}=\frac{d}{d t}\left(H+E_{C}+E_{P}\right)=d \dot{Q}+\dot{m}_{e n t} \cdot\left(\bar{H}+E_{C}+E_{P}\right)_{e n t}+\cdots \\
\cdots-\dot{m}_{s a i} \cdot\left(\bar{H}+E_{C}+E_{P}\right)_{s a i}
\end{gathered}
$$

Pelas hipóteses:

$$
\frac{d H}{d t}=-d \dot{Q}+\dot{m} \cdot\left[\left(\bar{H}+E_{C}+E_{P}\right)_{e n t}-\left(\bar{H}+E_{C}+E_{P}\right)_{s a i}\right]
$$




$$
\frac{\partial T_{T}}{d t} \cdot C p \cdot \rho \cdot d V_{T}=-d \dot{Q}+\dot{m} \cdot C p \cdot\left[T_{e n t}-T_{s a i}\right]
$$

em que $d V_{T}$ é o volume infinitesimal do fluido.

Além disso, como:

$$
d \dot{Q}=d A_{T} \cdot U_{T} \cdot \Delta T=d A_{T} U_{T} \cdot\left[T_{T}(x)-T_{\infty}\right]
$$

em que $A_{T}$ é a área infinitesimal de troca térmica do tubo, $U_{T}$ representa o coeficiente global de troca térmica entre o centro do tubo e a sua superfície e $T_{\infty}$ é o valor da temperatura externa ao tubo. Então, tem-se:

$$
\frac{\partial T_{T}}{d t} \cdot C p \cdot \rho \cdot d V_{T}=-d A_{T} \cdot U_{T} \cdot\left(T_{T}-T_{\infty}\right)+\dot{m} \cdot C p \cdot\left(T_{e n t}-T_{s a i}\right)
$$

sendo que:

$$
d V_{T}=\frac{\pi \cdot d^{2}}{4} \cdot d x \quad \text { e } \quad d A_{T}=2 \cdot \pi \cdot R \cdot d x=\pi \cdot d \cdot d x
$$

em que $d$ é o diâmetro interno do tubo.

Substituindo na equação principal, tem-se:

$$
\frac{\partial T_{T}}{d t} \cdot \frac{\pi \cdot d^{2} \cdot \rho \cdot L_{T}}{4 \cdot \dot{m}}=\frac{-\pi \cdot d \cdot L_{T} \cdot U_{T}}{C p \cdot \dot{m}} \cdot\left(T_{T}-T_{\infty}\right)+\frac{\left[T_{e n t}-T_{s a i}\right]}{d \eta}
$$

Inserindo $\tau_{T}$, o qual representa o tempo espacial do fluido dentro do tubo de retenção (em segundos), e o parâmetro adimensional auxiliar da modelagem $(\gamma)$, de acordo com Gutierrez et al. (2014), tem-se:

$$
\gamma=\frac{\pi \cdot L \cdot d \cdot U}{\dot{m} \cdot C p} \quad \text { e } \quad \tau_{T}=\frac{\pi \cdot L \cdot d^{2} \cdot \rho}{4 \cdot \dot{m}}=\frac{L_{T}}{v_{T}}
$$

Portanto, tem-se: 


$$
\frac{\partial T_{T}}{d t} \cdot \tau_{T}=-\gamma \cdot\left(T_{T}-T_{\infty}\right)+\frac{\left[T_{e n t}-T_{s a i}\right]}{\partial \eta}
$$

Pela definição de derivada, $\left[T_{e n t}-T_{\text {sai }}=d T\right]$, tem-se:

$$
\frac{\partial T_{T}}{d t} \cdot \tau_{T}=-\gamma \cdot\left(T_{T}-T_{\infty}\right)-\frac{\partial T_{T}}{\partial \eta}
$$

Essa equação representa a modelagem matemática devido ao balanço de energia num tubo genérico do pasteurizador, tendo em vista a hipótese de escoamento pistonado, como uma aproximação para esta análise.

\subsubsection{Modelagem da Letalidade nos Tubos}

O mesmo equacionamento realizado para os canais do trocador de calor a placas é utilizado para a distribuição de concentração (equação 4.63) e da letalidade (equação 4.64) para o tubo de retenção, bem como para os seus trechos. Porém, em apenas um único sentido de escoamento e usando o tempo espacial para o tubo $\left(\tau_{T}\right)$.

$$
\tau_{T} \cdot \frac{\partial C_{A, i}}{\partial t}+\frac{\partial C_{A, i}}{\partial \eta}=-\left[\tau_{T} \cdot\left(\frac{2,3026 \cdot C_{A, i}(\eta, t)}{D_{r e f} \cdot 10^{\left(\frac{T_{r e f}-T}{Z}\right)}}\right)\right]
$$

Essa equação representa a modelagem matemática devido ao balanço material do indicador alvo nos tubos do pasteurizador com relação ao espaço adimensionalizado $(\eta)$ e ao tempo $(t)$.

A incrustação do produto nas paredes internas dos tubos não foi modelada. Isso porque as suas paredes não estão a temperatura maior do que a do leite, como no caso das placas da seção de aquecimento, sendo esse um fator que corrobora significativamente para a deposição na superfície de troca térmica. Logo, a modelagem da incrustação nos tubos (retenção e conexões) foi negligenciada. 


\subsection{Condições de Contorno}

Com base nas equações diferenciais, identifica-se a necessidade de condições de contorno a fim de realizar a simulação numérica do sistema dos modelos obtidos. Baseado nisso, são definidas condições para temperatura, nos canais do trocador de calor a placas $\left[T_{i}(\eta)\right]$, nas placas do PHE $\left[T_{p, i}(\eta)\right]$ e no tubo de retenção bem como em seus trechos $\left[\left(T_{T}(\eta)\right]\right.$. Já para o balanço material para o indicador alvo, neste caso os micro-organismos, é definida a concentração nos canais e nos tubos do pasteurizador $\left[C_{A, i}(\eta)\right]$.

\subsubsection{Nos Canais e no Tubo de Retenção para Temperatura}

As condições aqui são aplicadas tanto para entrada como para saída dos canais do PHE. Logo, de forma geral, de acordo com Gutierrez et al. (2014), tem-se:

- No primeiro passe, a temperatura de alimentação equivale a temperatura do fluido no início do primeiro passe, ou seja:

$$
T_{i}(\eta)=T_{\text {ent }} \quad, i \in \text { primeiro passe }
$$

- Na mudança de passe, a temperatura de saída do passe é igual ao somatório das temperaturas de saída dos canais dividido pelo número de canais do passe:

$$
T_{i}(\eta)=\frac{1}{N} \cdot \sum_{\substack{j \in \text { ao passe } \\ \text { anterior }}}^{N} T_{j}(\eta) \quad, i \in \text { novo passe }
$$

- No último passe, a temperatura de saída do fluido é a mistura perfeita do fluido que deixa o mesmo, então:

$$
T_{\text {sai }}(\eta)=\frac{1}{N} \cdot \sum_{\substack{j \in \text { ao último } \\ \text { passe }}}^{N} T_{j}(\eta)
$$


Exemplificando um PHE com arranjo em série e que o número de canais por passe é igual a um, com $N_{C}=12$ canais e com 13 placas, como o mostrado na Figura 4.9, tem-se as equações de condição de contorno nos canais na sequência:

- Lado I:

$$
\begin{aligned}
& T_{\text {ent }}=T_{1}(\eta=0) \\
& T_{1}(\eta=1)=T_{3}(\eta=1) \\
& T_{3}(\eta=0)=T_{5}(\eta=0) \\
& \cdots \\
& T_{7}(\eta=0)=T_{9}(\eta=0) \\
& T_{9}(\eta=1)=T_{11}(\eta=1) \\
& T_{11}(\eta=0)=T_{\text {sai }}
\end{aligned}
$$

- Lado II:

$$
\begin{aligned}
& T_{\text {sai }}=T_{2}(\eta=0) \\
& T_{2}(\eta=1)=T_{4}(\eta=1) \\
& T_{4}(\eta=0)=T_{6}(\eta=0) \\
& \ldots \\
& T_{8}(\eta=0)=T_{10}(\eta=0) \\
& T_{10}(\eta=1)=T_{12}(\eta=1) \\
& T_{12}(\eta=0)=T_{\text {ent }}
\end{aligned}
$$

Pelas hipóteses descritas anteriormente, tem-se a equação 4.87 para a extremidade superior e inferior de uma placa, as quais são adiabáticas. Isto é, esta condição descreve que não há troca de calor nas extremidades das placas do PHE, dos quais os valores de $\eta$ são 0 ou 1 . Então:

$$
\left.\frac{\partial T_{p, i}}{\partial \eta}\right|_{\eta=0, \eta=1}=0 \quad, i=1,2 \ldots N_{C}-1
$$


Pela Figura 4.9 é possível observar um esquema o qual exemplifica a estrutura acima, bem como parte do processo discretizado estudado para um caso específico de configuração, em que o número de canais por passe é igual a um, para um trocador de calor com 13 placas e com 12 canais, com arranjo em série, como já mencionado.

Figura 4.9 - Exemplo de arranjo em série de um PHE com 12 canais e 13 placas.

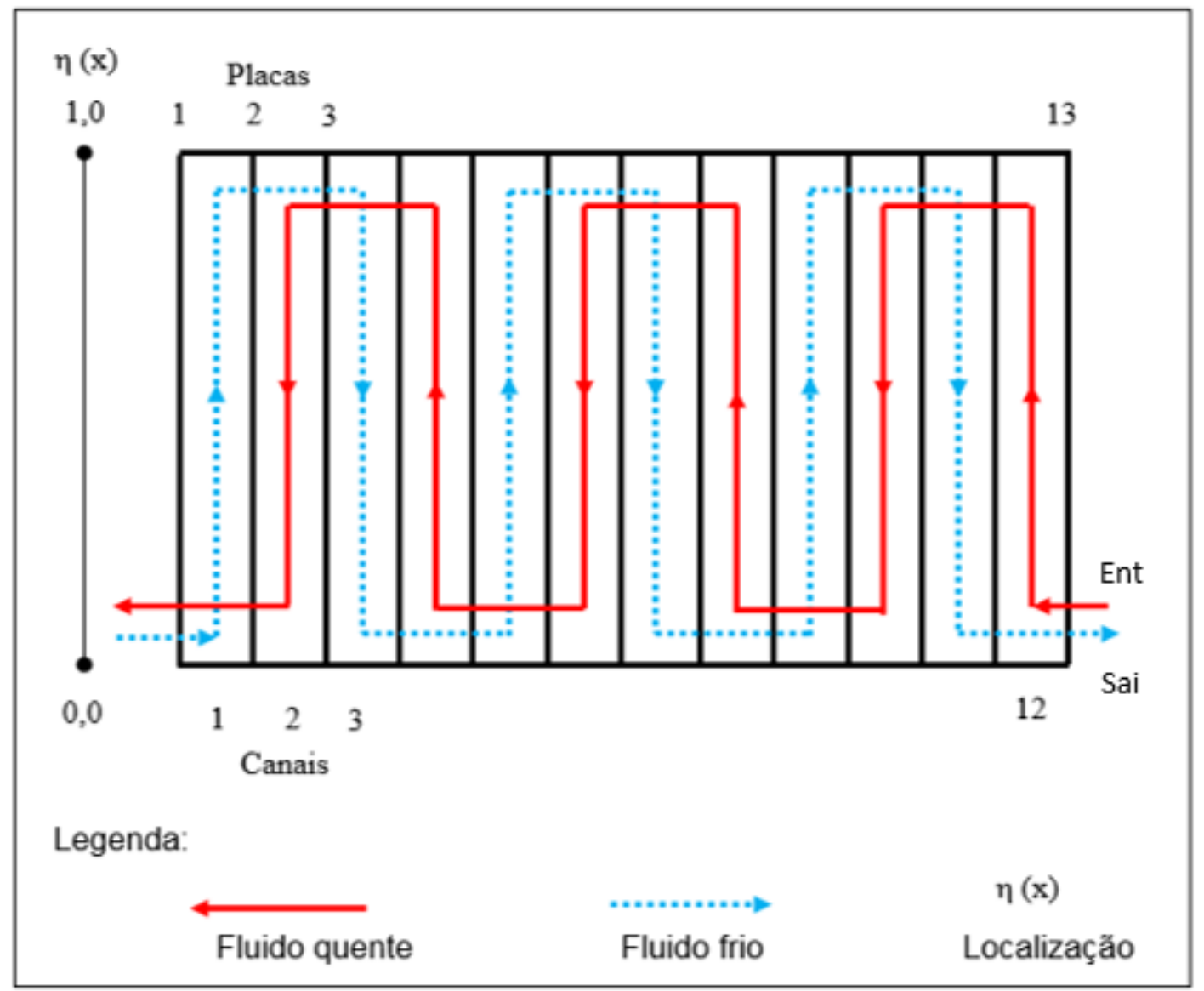

Fonte: elaboração do autor (2016).

Neste sentido, partindo da Figura 4.1, a qual ilustra a visão global do processo de pasteurização e seus pontos de controle, têm-se as respectivas condições de contorno, para o leite, tanto para sua temperatura como para a concentração do indicador alvo, e para as utilidades de aquecimento e resfriamento:

$>T_{\text {ent,leite cru }}$ ou $C_{\text {ent,leite cru }}=T_{\text {ent,I }}$ ou $C_{\text {ent,I }}($ regeneração $) \rightarrow \boldsymbol{T 1}$ ou $\boldsymbol{C 1}$

$>T_{\text {sai, }, \text { ou }} C_{\text {sai,I }}($ regeneração $)=T_{\text {ent,I }}$ ou $C_{\text {ent }, I}$ (aquecimento) $\rightarrow$ T2 ou C2

$>T_{\text {sai }, I}$ ou $C_{\text {sai, },}$ (aquecimento) $=T_{\text {ent }}$ ou $C_{\text {ent }}($ tubo 1$) \rightarrow$ T3 ou C3

$>T_{\text {sai }}$ ou $C_{\text {sai }}($ tubo 1$)=T_{\text {ent }}$ ou $C_{\text {ent }}($ tubo $2-$ retenção $) \rightarrow \boldsymbol{T 4}$ ou $\boldsymbol{C 4}$ 
$>T_{\text {sai }}$ ou $C_{\text {sai }}($ tubo $2-$ retenção $)=T_{\text {ent }}$ ou $C_{\text {ent }}($ tubo 3$) \rightarrow \boldsymbol{T 5}$ ou $\mathbf{C 5}$

$>T_{\text {sai }}$ ou $C_{\text {sai }}($ tubo 3$)=T_{\text {ent,II }}$ ou $C_{\text {ent,II }}($ regeneração $) \rightarrow \boldsymbol{T 6}$ ou $\mathbf{C 6}$

$>T_{\text {sai,I }}$ ou $C_{\text {sai,I }}$ (regeneração) $=T_{\text {ent,I }}$ ou $C_{\text {ent,I }}$ (resfriamento $) \rightarrow \boldsymbol{T 7}$ ou C7

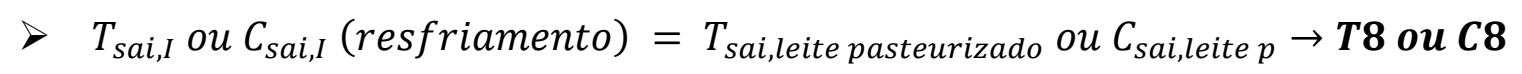

$>T_{\text {ent, utilidade de aquecimento }}=T_{\text {ent,II }}($ entrada do aquecimento $) \rightarrow$ T9 (água)

$>T_{\text {sai,II }}($ saída do aquecimento $)=T_{\text {sai,utilidade de aquecimento }} \rightarrow \boldsymbol{T 1 0}$ (água)

$>T_{\text {ent,utilidade de resfriamento }}=T_{\text {ent,II }}$ (entrada do resfriamento) $\rightarrow \boldsymbol{T 1 1}$ (água)

$>T_{\text {sai,II }}($ saída do resfriamento $)=T_{\text {sai,utilidade de resfriamento }} \rightarrow \boldsymbol{T 1 2}$ (água)

Apenas para ressaltar, as indicações $\mathrm{T} 1, \mathrm{~T} 2, \mathrm{~T} 3 \ldots$ e $\mathrm{T} 12$ referem-se às temperaturas do leite e das utilidades de aquecimento e resfriamento nos pontos de controle do pasteurizador (Figura 4.1). Já as indicações $T_{1}, T_{2} \ldots T_{i}$ referem-se às temperaturas do leite nos canais dos PHE, ao longo do processo. Por último, C1, C2, C3... e C8 indicam a concentração microbiana por todo o pasteurizador.

A condição de contorno no tubo de retenção e em seus trechos é que a temperatura de entrada em um trecho de tubo seja igual a de saída da parcela anterior. Segue-se o mesmo raciocínio para a concentração microbiana.

\subsubsection{Nos Canais e no Tubo de Retenção para Micro-organismos}

As condições de contorno para balanço microbiano são similares às usadas para temperatura, tanto de forma global quanto de forma discretizada, porém, neste caso, para concentração do micro-organismo, $C_{A, i}$. Outra diferença é que o estudo da concentração é feito apenas para o leite, excluindo as utilidades quente e fria.

\subsubsection{Nos Canais para Incrustação}

A incrustação é considerada apenas na seção de aquecimento. Então, nas outras seções e no tubo de retenção do equipamento, tem-se:

$$
\left.R_{f}\right|_{\text {resfriamento,retenção,tubos e regeneração }}=0
$$


Além disso, no PHE de aquecimento, considera-se que não há incrustação nos canais que escoam água limpa, apenas nos canais com produto.

\subsection{Condições Iniciais}

Neste trabalho foram utilizadas duas condições iniciais diferentes para 0 processo de pasteurização. A primeira é que pasteurizador seja avaliado a partir do estado estacionário. Portanto, tem-se:

$$
\left.\frac{\partial T_{i}}{\partial t}\right|_{t=0} ;\left.\quad \frac{\partial T_{p}}{\partial t}\right|_{t=0} ;\left.\quad \frac{\partial T_{T}}{\partial t}\right|_{t=0} \quad ;\left.\quad \frac{\partial C_{A, i}}{\partial t}\right|_{t=0} ;\left.\quad \frac{\partial R_{f}}{\partial t}\right|_{t=0}=0
$$

A segunda é a condição inicial de partida, na qual inicialmente todos os fluidos (leite e utilidades), as placas do pasteurizador e a temperatura ambiente estejam a uma mesma temperatura, não havendo transferência de calor, ou seja:

$$
\left.T_{i}\right|_{t=0}=\left.T_{p}\right|_{t=0}=\left.T_{T}\right|_{t=0}=T_{\text {inicial }}
$$

Para letalidade, durante a partida, considera-se que a concentração microbiana inicial para o indicador alvo na entrada do pasteurizador $\left(C_{A, \text { ent }}\right)$ seja um valor que evite erros numéricos no software e que esteja de acordo com a legislação brasileira, a qual estabelece que o limite máximo para concentração microbiana para mesófilos, no leite cru, seja de, no máximo, 5,0 x 105 UFC/mL (BRASIL, 2002). Logo, no início do processo:

$$
t=0 \quad \rightarrow \quad C_{A, \text { ent }}=1 \times 10^{5} \mathrm{UFC} / \mathrm{mL}
$$

Essas condições - iniciais e de contorno - para temperatura do processo, concentração microbiológica do indicador alvo e de incrustação do leite foram adotadas de modo a garantir cenários de estudo do modelo próximos da realidade da maioria das unidades processadoras de leite. Contudo, algumas vezes essas variáveis eram modificadas para avaliar os diferentes cenários ou efeitos de oscilações de processo, nas simulações, como mostrado na seção seguinte. 


\section{ESTUDO DE CASO}

A modelagem matemática desenvolvida no Capítulo 4, bem como a sua posterior simulação, foi aplicada e avaliada para um estudo de caso com leite baseada em um pasteurizador a placas de escala laboratorial.

Nessa seção são mostradas as características das placas do PHE, o equipamento estudado bem como a sua configuração, condições de operação e propriedades dos fluidos usados.

O projeto de pesquisa foi desenvolvido nas dependências do Laboratório de Engenharia de Alimentos (LEA), situado no Departamento de Engenharia Química da Escola Politécnica da USP, na cidade de São Paulo.

\subsection{Equipamento Avaliado}

Na Figura 5.1 é possível observar o equipamento utilizado no estudo de caso e na validação experimental do modelo da incrustação do produto.

Figura 5.1 - Pasteurizador laboratorial FT-43 (Armfield, UK) empregado no estudo.

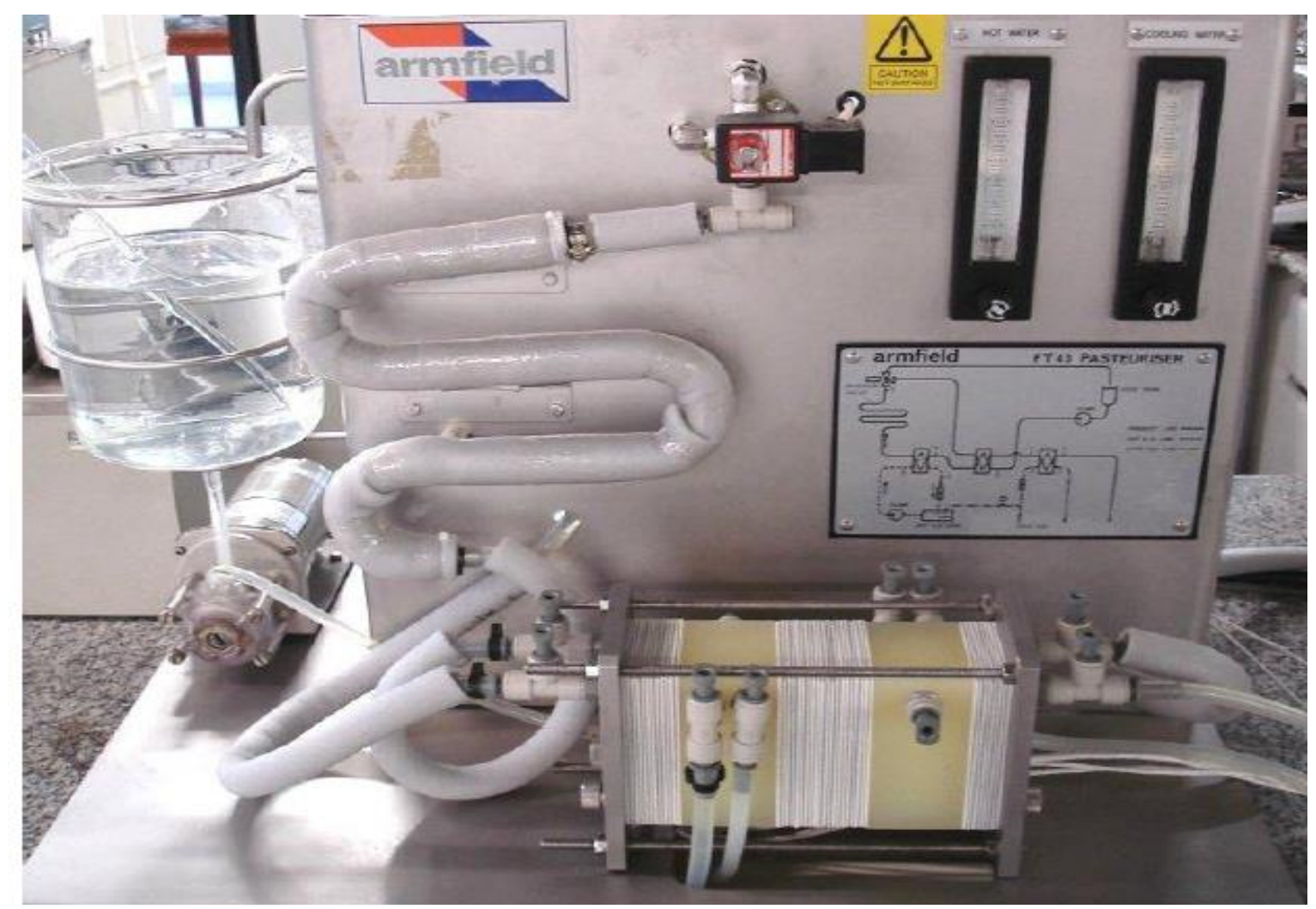

Fonte: elaboração do autor (2016). 
O estudo de caso foi realizado em um pasteurizador do tipo placas FT-43 (Armfield, UK), com placas lisas de aço inoxidável, separadas por gaxetas de silicone, alimentado por uma bomba peristáltica 7017-20 (Masterflex, USA), composto por três seções: regeneração, aquecimento e resfriamento. Os três PHEs são incorporados em um único pedestal. O sistema também é composto pelo tanque de alimentação (4 L), pelo tubo de retenção e suas duas conexões e pela válvula diversora de fluxo, sendo o equipamento já mostrado na Figura 5.1 Os seus componentes deste são: unidade processadora de pasteurização, console de controle, unidade de refrigeração modelo FT61-B e interface de aquisição de dados modelo FT43 A-90 IFD. De acordo com o fabricante, as especificações técnicas da máquina são:

- Bomba de alimentação do tipo peristáltica, marca MASTERFLEX, capacidade máxima $200 \mathrm{~L} / \mathrm{h}$ e capacidade nominal de $20 \mathrm{~L} / \mathrm{h}$;

- Controlador de temperatura de pasteurização do tipo microprocessador com ação PID para o aquecedor de água, faixa de $0{ }^{\circ} \mathrm{C}$ a $100{ }^{\circ} \mathrm{C}$;

- Placas lisas de aço inoxidável AISI 316, com gaxetas em silicone de grau sanitário e área de troca térmica unitária $50,1 \mathrm{~cm}^{2}$;

- Sistema de aquecimento composto por bomba centrífuga de circulação de água quente, a qual é aquecida por uma resistência elétrica de capacidade 1,5 kW. A vazão de água quente é variável através da válvula agulha do rotâmetro em até $1,5 \mathrm{~L} / \mathrm{min}$;

- Sistema de resfriamento ARMFIELD modelo FT-61 com bomba centrífuga interna que opera até $4^{\circ} \mathrm{C}$. A vazão de água fria é variável através da válvula agulha do rotâmetro até $1,5 \mathrm{~L} / \mathrm{min}$;

- Tubo de retenção em formato de "S" com volume interno de $75 \mathrm{~cm}^{3}$ e com isolamento térmico.

O tubo de retenção do equipamento (padrão de $72{ }^{\circ} \mathrm{C}$ por $15 \mathrm{~s}$ ), o qual possui volume interno de $75 \mathrm{~mL}$, está conectado aos trocadores por duas mangueiras de silicone, ou conexões, uma de cada lado de suas extremidades, com isolamento térmico em espuma. A Tabela 5.1 apresenta os valores das dimensões físicas do tubo de retenção e de suas duas conexões. 
Tabela 5.1 - Dimensões do tubo de retenção e suas conexões.

\begin{tabular}{ccc}
\hline Elemento & Comprimento $(\mathrm{m})$ & Diâmetro interno $(\mathrm{m})$ \\
\hline Conexão 1 & 0,48 & $9,50 \times 10^{-3}$ \\
Tubo de retenção & 0,83 & $1,07 \times 10^{-2}$ \\
Conexão 2 & 1,17 & $6,00 \times 10^{-3}$ \\
\hline
\end{tabular}

Fonte: elaboração do autor (2016).

As propriedades físicas e as dimensões das placas do equipamento estudado podem ser observadas na Tabela 5.2 Além disso, as medidas das gaxetas bem como o seu esboço são descritos na Figura 5.2.

Tabela 5.2 - Características das placas do pasteurizador ARMFIELD FT-43A.

\begin{tabular}{ccc}
\hline Características & Valor & Unidade \\
\hline Comprimento da parte úmida, $L$ & $8,35 \times 10^{-2}$ & $\mathrm{~m}$ \\
Largura da parte úmida, $w$ & $6,00 \times 10^{-2}$ & $\mathrm{~m}$ \\
Espessura do canal, $b$ & $1,50 \times 10^{-3}$ & $\mathrm{~m}$ \\
Diâmetro do orifício, $D_{P}$ & $8,00 \times 10^{-3}$ & $\mathrm{~m}$ \\
Espessura da placa, $e_{P}$ & $1,00 \times 10^{-3}$ & $\mathrm{~m}$ \\
Fator de alargamento, $\Phi$ & 1,00 & - \\
Área de troca térmica, $A_{P}$ & $5,01 \times 10^{-3}$ & $\mathrm{~m} / \mathrm{placa}$ \\
Condutividade térmica, $k_{P}$ & $1,34 \times 10$ & $\mathrm{~W} / \mathrm{m} \cdot \mathrm{K}$ \\
Capacidade calorífica da placa, $C p_{P}$ & 468,0 & $\mathrm{~J} / \mathrm{kg} \cdot \mathrm{K}$ \\
Densidade da placa, $\rho_{P}$ & 8238,0 & $\mathrm{~kg} / \mathrm{m}^{3}$
\end{tabular}

Fonte: Gut, Pinto, 2004; Armfield, 2014.

$\mathrm{Na}$ Figura 4.1 estão indicados doze pontos de interesse para a controle da temperatura do leite, durante o processo, além dos pontos referentes às utilidades de aquecimento e de resfriamento, sendo esses os pontos de registro de dados de temperatura do fluido ao longo do tempo.

O arranjo das três seções do trocador de calor foi do tipo em série (um canal por passe) e contracorrente. Foram considerados dez passes de um canal na regeneração, seis passes de um canal no aquecimento e quatro passes de um canal no resfriamento, seguindo recomendação do fabricante. 
Figura 5.2 - Dimensões em milímetros da gaxeta do PHE.

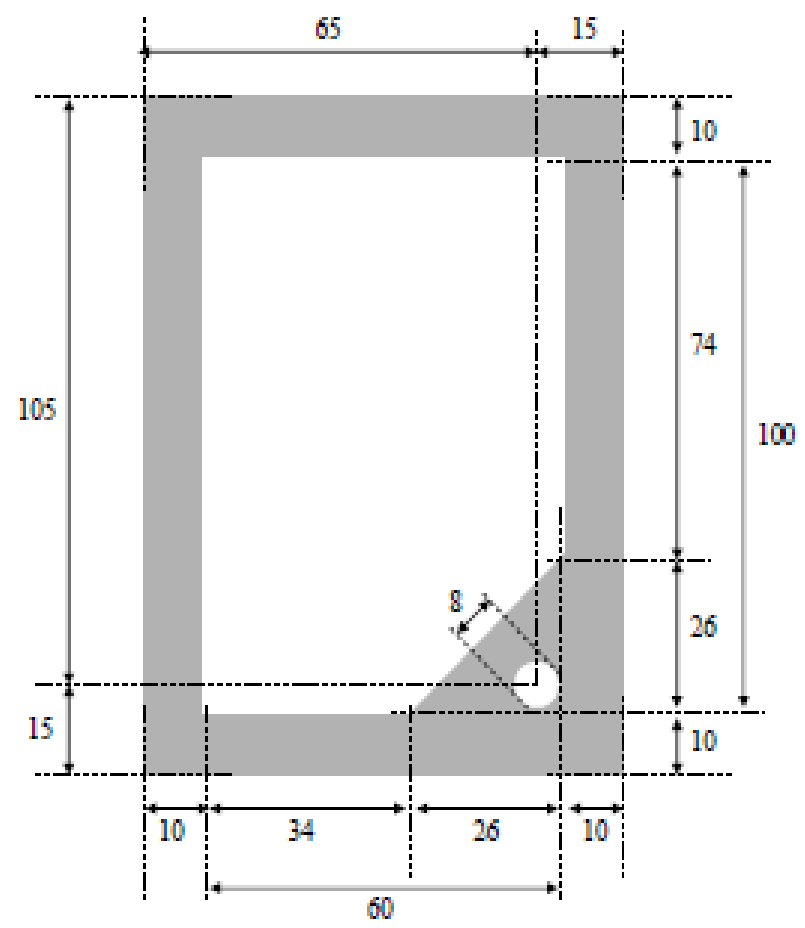

Fonte: Gutierrez, 2008.

Os principais parâmetros da configuração adotada para a simulação do processo de pasteurização são mostrados na Tabela 5.3.

Tabela 5.3 - Parâmetros da configuração das 3 seções do PHE estudado.

\begin{tabular}{cccc}
\hline Parâmetro & Regeneração & Aquecimento & Resfriamento \\
\hline$N_{C}$ & 20 & 12 & 8 \\
$P^{I}$ & 10 & 6 & 4 \\
$P^{I I}$ & 10 & 6 & 4 \\
$\varnothing$ & 3 & 3 & 3 \\
$Y_{h}$ & 0 & 0 & 1 \\
$Y_{f}$ & 1 & 1 & 1 \\
\hline
\end{tabular}

Fonte: elaboração do autor (2016).

$\mathrm{Na}$ maioria das simulações realizadas, adotou-se a vazão de produto como sendo a de condição nominal do equipamento, $20 \mathrm{~L} / \mathrm{h}$, e a vazão das utilidades de aquecimento e de resfriamento (água) como sendo $60 \mathrm{~L} / \mathrm{h}$. Contudo, para algumas simulações, esses valores foram alterados a fim de possibilitar o estudo de perturbações no processo. 
Os valores utilizados para os coeficientes globais de troca térmica entre fluido e ar ambiente nas conexões e no tubo de retenção foram obtidos experimentalmente por Gutierrez (2013), e podem ser vistos na Tabela 5.4.

Tabela 5.4 - Coeficientes globais de troca térmica entre fluido e o ar para o tubo de retenção e suas conexões.

\begin{tabular}{cc}
\hline Seção & $U_{T}\left(\mathrm{~W} / \mathrm{m}^{2} . \mathrm{K}\right)$ \\
\hline Conexão 1 & 6,1 \\
Tubo de Retenção & 16,0 \\
Conexão 2 & 47,0 \\
\hline
\end{tabular}

Fonte: Gutierrez, 2013.

Os valores usados para os parâmetros experimentais da correlação de Nusselt, citada no capítulo 4 (equação 4.10), são baseados no estudo de Miura (2006), que ajustou a equação 5.1 como correlação para determinação do coeficiente convectivo nos canais do PHE para arranjo de passes em série $(N=1)$, sendo isso válido para água.

$$
N u=0,0263 \cdot R e^{0,867} \cdot \operatorname{Pr}^{0,333}
$$

O cálculo do tempo espacial $(\tau)$ para o leite bovino, na vazão nominal do equipamento $(20 \mathrm{~L} / \mathrm{h})$, em cada seção do trocador, foi realizado a partir das equações 5.2 e 5.3 e os valores obtidos podem ser vistos na tabela 5.5 .

$$
\begin{array}{ll}
\tau_{\text {total }, s}=\tau_{s} \cdot P^{I} & \text {, se for para o lado } I \text { do PHE } \\
\tau_{\text {total }, s}=\tau_{s} \cdot P^{I I} & \text {, se for para o lado } I I \text { do PHE }
\end{array}
$$

em que $\tau_{s}$ é o tempo espacial do produto na seção em questão, obtido a partir de $\tau_{i}$ pela equação 4.32, sendo que $s$ é equivalente à seção de aquecimento, resfriamento e/ou regeneração, e os valores de $P^{I}$ e $P^{I I}$ podem ser vistos na Tabela 5.5. Para o tubo de retenção e suas conexões, a equação usada foi a 4.77 , para $\tau_{T}$. 
Tabela 5.5 - Valores calculados de tempo espacial para leite ao longo no processo.

\begin{tabular}{cc}
\hline Seção do Pasteurizador & Tempo espacial (s) \\
\hline Regeneração (entrada) & 13,53 \\
Aquecimento & 8,12 \\
Conexão 1 & 6,12 \\
Tubo de Retenção & 13,43 \\
Conexão 2 & 6,77 \\
Regeneração (saída) & 13,53 \\
Resfriamento & 5,41
\end{tabular}

Fonte: elaboração do autor (2016).

Uma alternativa para representar o escoamento nos canais do trocador e nos tubos é substituir o tempo espacial teórico $(\tau)$ pelo tempo médio de residência $t_{m}$ que é determinado experimentalmente e que, devido às zonas de estagnação do fluido ao longo de seu escoamento: $t_{m}<\tau$ (LEVENSPIEL, 2007).

O cálculo do tempo médio de residência $\left(t_{m}\right)$ pode ser baseado na somatória dos volumes de plug flow e de mistura perfeita do produto, sendo que a diferença entre a soma destes volumes é inferior ao volume interno do trocador, ou seja, o seu volume morto (GUTIERREZ et al., 2011).

\subsection{Micro-organismo Estudado}

Os parâmetros cinéticos relativos à inativação térmica do micro-organismo avaliado neste trabalho - a bactéria Coxiella burnetii - são mostrados na Tabela 5.6.

Tabela 5.6 - Parâmetros cinéticos relativos à inativação térmica da $C$. burnetii.

\begin{tabular}{ccc}
\hline Parâmetro & Valor & Unidade \\
\hline$D_{\text {ref }}$ & 1,88 & $\mathrm{~S}$ \\
$T_{\text {ref }}$ & 72,0 & ${ }^{\circ} \mathrm{C}$ \\
$z$ & 4,34 & ${ }^{\circ} \mathrm{C}$ \\
\hline
\end{tabular}

Fonte: Cerf e Condron, 2006.

Como já comentado anteriormente, a concentração inicial de micro-organismos foi considerada como igual a 1,0 x 105 UFC/mL para a maioria das simulações, porém 
para outras - cenários com perturbações do sistema -, esse valor variou de acordo com cada tipo de estudo realizado no estudo de caso. Como dito anteriormente, esse valor foi escolhido com base na solução numérica do problema pelo software e também devido ao fato que a legislação brasileira estabelece que o limite máximo para concentração microbiana para mesófilos, no leite cru, é de 5,0 × 105 $\mathrm{UFC} / \mathrm{mL}$ (BRASIL, 2002). Além disso, estudos quantificam que este valor está dentro da faixa média encontrada para produtores rurais de leite bovino cru, sendo de $1 \times 10^{4}$ a $1 \times 10^{6}$ UFC/mL (PINTO et al., 2006).

\subsection{Propriedades dos Fluidos Utilizados}

A fim de calcular algumas das propriedades termofísicas da água de aquecimento e de resfriamento foram utilizadas as equações 5.2 a 5.5 , todas para temperaturas entre 0 e $90^{\circ} \mathrm{C}$, compiladas por Gut e Pinto (2003c):

$$
\begin{aligned}
& \rho=2,080 \times 10^{-5} \cdot T^{3}-6,668 \times 10^{-3} \cdot T^{2}+0,0468 \cdot T+999,9 \\
& \mu=\frac{1}{21,482 \cdot\left[(T-8,435)+\sqrt{8078,4+(T-8,435)^{2}}\right]-1200} \\
& \begin{array}{l}
C p=5,201 \times 10^{-7} \cdot T^{4}-2,153 \times 10^{-4} \cdot T^{3}+4,176 \times 10^{-2} \cdot T^{2}- \\
2,617 \cdot T+4226,1
\end{array} \\
& k=0,5692+\frac{T}{538}-\frac{T^{2}}{1,333 \times 10^{5}}
\end{aligned}
$$

Todas essas propriedades, densidade, $\rho\left(\mathrm{kg} / \mathrm{m}^{3}\right)$, viscosidade, $\mu$ (Pa.s), calor específico, $C p(\mathrm{~J} / \mathrm{kg} . \mathrm{K})$ e condutividade térmica, $k(\mathrm{~W} / \mathrm{K} . \mathrm{m})$, dependem da temperatura média da seção do equipamento em ${ }^{\circ} \mathrm{C}$.

Similarmente, para se determinar os valores das propriedades termofísicas do leite, utilizou-se as correlações 5.6 a 5.9 , também para temperaturas entre 0 e $90^{\circ} \mathrm{C}$. O cálculo dos parâmetros como densidade $(\rho)$, viscosidade $(\mu)$ e condutividade térmica $(k)$ estão de acordo com Cheng e Friis (2007), e o calor específico $(C p)$ com Choi e Okos (1986). Os elementos $x_{w}$ e $x_{L}$ representam as frações mássica de água e lipídeos presentes no leite bovino, respectivamente. 


$$
\begin{aligned}
& \begin{aligned}
\rho=(1040,7- & \left.0,2665 \cdot T-2,3 \times 10^{-3} \cdot T^{2}\right)-x_{L}\left(1,011+9,76 \times 10^{-3} \cdot T\right. \\
& \left.-4,81 X 10^{-5} \cdot T^{2}\right)
\end{aligned} \\
& \begin{aligned}
\mu=[(0,9565 & \left.-1,3004 X 10^{-3} \cdot T+1,958 X 10^{-4} \cdot T^{2}\right)+x_{L} \cdot(0,4766 \\
& \left.\left.-0,0114 \cdot T+7,2642 X 10^{-5} \cdot T^{2}\right)\right] X 10^{-3}
\end{aligned} \\
& k=\left(0,528+0,00123 \cdot T-0,732 X 10^{-5} \cdot T^{2}\right) \cdot\left[1-x_{L}(0,843+0,0019\right. \\
& \quad \cdot T)] \\
& C p=1275+2512 \cdot x_{w}
\end{aligned}
$$

Os valores usados para $x_{w}$ e $x_{L}$ (em fração mássica) são baseados na composição média do leite bovino integral fluido, de acordo com a Tabela 3.1.

\subsection{Simulação}

O modelo construído apresentou um conjunto de equações diferenciais ordinárias de primeira e segunda ordem, com número de graus de liberdade nulo, e a sua resolução foi feita pelo método das diferenças finitas usando o software gPROMS (Process System Enterprise, versão 4.0).

A modelagem é composta por balanços de energia nos canais e nas placas dos três PHEs (equação 4.37 e equação 4.50, respectivamente) e no tubo de retenção e em suas conexões (equação 4.79), considerando variação espacial unidimensional e temporal. Os balanços de material (micro-organismos) foram realizados nos canais que escoam leite (equação 4.63), na retenção e em suas conexões (equação 4.80), em relação ao tempo e ao espaço unidimensional. A incrustação foi computada apenas na seção de aquecimento do PHE em relação ao tempo (equação 4.67).

Foram incluídas as condições de contorno para temperatura e concentração microbiana nos canais dos PHEs e nos tubos conforme discutido na seção 4.3. Condições de contorno para ligação entre as seções foram previstas (Figura 4.1 e seção 4.3). Também foram definidas as condições iniciais para temperatura, concentração microbiológica e incrustação do leite na seção 4.3.

As propriedades termofísicas do leite e da água (equações da seção 5.3), os parâmetros da modelagem (equação do Capítulo 4) e de engenharia (equação do 
Capítulo 4) foram calculados em planilha eletrônica do Excel (Microsoft, EUA) e com base nas médias das temperaturas estimadas entre a entrada e a saída de cada seção do equipamento e fornecidos ao programa a fim de facilitar a simulação.

Os valores das dimensões do equipamento, placas (Tabela 5.2), tubos (Tabela 5.1 e 5.4), área de troca térmica (Tabela 5.2), configuração dos PHEs (Tabela 5.3) e das características de escoamento (Tabela 5.5), foram determinados como prérequisito à simulação e são mostrados na Seção 5.1 .

A escolha dos métodos de discretização para a simulação do processo foi definida em razão dos testes de simulação dinâmica de um PHE com o intuito de eliminar problemas de estabilidade numérica apresentados no trabalho de Gut (2003). Ou seja, os métodos de discretização utilizados na simulação deste trabalho foram:

a) Método de Diferenças Finitas Centradas, do inglês Centered Finite Difference Method (CFDM), para a temperatura nas placas do PHE;

b) Método de Diferenças Finitas para Trás, do inglês Backward Finite Difference Method (BFDM), para a temperatura nos canais, em que a direção do escoamento é no sentido positivo $(\eta)$, para o tubo de retenção e seus trechos. Também para a concentração do micro-organismo alvo;

c) Método de Diferenças Finitas para Frente, do inglês Forward Finite Difference Method (FFDM), para a temperatura nos canais, em que a direção do fluido é no sentido negativo de $\eta$ e também para a concentração de micro-organismos;

Os números de pontos de discretização utilizados na simulação foram: 30 pontos para canais e placas do trocador de calor e 40 pontos para o tubo de retenção e seus trechos. Estes valores foram adotados com base em simulações com maior número de pontos, sendo que não houve variações significativas nos resultados, mas apenas aumento do tempo computacional. Logo, foi considerado desnecessário o aumento de pontos de discretização. As variáveis discretizadas foram a temperatura ao longo dos canais e das placas dos trocadores, tubo de retenção e das conexões do pasteurizador, e a concentração de micro-organismos nos canais e no tubo de retenção e em suas conexões.

Todas as simulações foram realizadas com uso da máquina de processador Inter® Core ${ }^{\mathrm{TM}}$ i3-3220 CPU @ 3,30 GHz de frequência, com memória instalada (RAM) de 4,0 GB e sistema operacional de 64 Bits. 
A temperatura ambiente adotada durante nas simulações foi de $20^{\circ} \mathrm{C}$, pois representa o valor médio da cidade de São Paulo no ano de 2010 (AKAMINE, 2012).

\subsection{Casos Estudados}

A fim de estudar e entender o comportamento dos modelos desenvolvidos para o processo de pasteurização contínuo foram feitas diversas simulações com base em situações possíveis em uma indústria alimentícia. Neste sentido, as simulações feitas foram: partida do processo; perturbações no sistema e simulação do processo em estado estacionário. Essas simulações foram realizadas com o intuito de avaliar os perfis de temperatura do leite, de concentração de micro-organismos e de letalidade do tratamento térmico avaliado, ao longo do tempo, ao longo do processo.

Para todas as simulações dinâmicas, com perturbação no processo de pasteurização, foi utilizada uma mesma metodologia, sendo a única diferença nos valores dos parâmetros operacionais entre os diferentes casos estudados.

As Tabelas 5.7 a 5.14 fornecem as informações dos parâmetros usados e das condições operacionais do sistema para as respectivas simulações.

Tabela 5.7 - Parâmetros utilizados na simulação de partida do pasteurizador.

\begin{tabular}{c|ccc}
\hline \multirow{2}{*}{ Parâmetros } & \multicolumn{3}{c}{ Tempo de processo (s) } \\
\cline { 2 - 4 } & $0-60$ & $60-360$ & $360-711$ \\
\hline$\dot{m}_{\text {leite }}(\mathrm{L} / \mathrm{h})$ & - & - & 20,0 \\
$\dot{m}_{\text {água,fria }}(\mathrm{L} / \mathrm{h})$ & 60,0 & 60,0 & 60,0 \\
$\dot{m}_{\text {água,produto }}(\mathrm{L} / \mathrm{h})$ & 20,0 & 20,0 & - \\
$\dot{m}_{\text {água,quente }}(\mathrm{L} / \mathrm{h})$ & 60,0 & 60,0 & 60,0 \\
$T_{\text {in,leite cru }}\left({ }^{\circ} \mathrm{C}\right)$ & - & - & 10,0 \\
$T_{\text {in,água }}\left({ }^{\circ} \mathrm{C}\right)$ & 20,0 & 20,0 & - \\
$T_{\text {in,água fria }}\left({ }^{\circ} \mathrm{C}\right)$ & 20,0 & 5,0 & 5,0 \\
$T_{\text {in,água quente }}\left({ }^{\circ} \mathrm{C}\right)$ & 20,0 & 90,0 & 90,0 \\
$C_{\text {in,leite }}(\mathrm{UFC} / \mathrm{mL})$ & - & - & $1,0 \times 10^{5}$ \\
Produto & Água & Água & Leite
\end{tabular}


A Tabela 5.7 mostra o cenário ao qual foi feita a simulação em função das condições operacionais do processo. Ou seja, para este caso, do instante $t=0 \mathrm{~s}$ até 0 instante $t=60 \mathrm{~s}$ partiu-se o equipamento apenas com água, considerando todos os fluidos a mesma temperatura $\left(20^{\circ} \mathrm{C}\right)$. Na sequência, do instante $t=60 \mathrm{~s}$ até $t=360$ $\mathrm{s}$, o processo se manteve com água, mas as utilidades de aquecimento e resfriamento passaram para suas respectivas temperaturas operacionais, $5^{\circ} \mathrm{C}$ e $90{ }^{\circ} \mathrm{C}$, nesta exata ordem. Por fim, após $360 \mathrm{~s}$ de tempo de processo, o equipamento recebeu o leite bovino, numa temperatura de entrada de $10{ }^{\circ} \mathrm{C}$, na entrada da regeneração, simulando o start up do pasteurizador. Contudo, para este caso, o equipamento ficou temporariamente preenchido com água de processo e leite ao mesmo tempo. Então, o procedimento usado nesta simulação foi baseado em:

- Inserção dos novos valores das propriedades termofísicas, parâmetros da modelagem e de engenharia (leite em lugar da água), uma vez que estes dependem do produto que está escoando no equipamento (equações da seção 5.3 e do Capítulo 4) de acordo com o deslocamento do leite dentro do pasteurizador;

- Consideração do deslocamento ou escoamento concomitante do leite (entrando no sistema) e da água de processo (saindo) dentro do equipamento, ao longo da pasteurização, como base em seus tempos espaciais (Tabela 5.5).

Esses novos valores foram todos calculados em planilha Excel e foram inseridos no algoritmo do programa, no software gPROMS, como perturbações sucessivas, sendo atualizados sequencialmente, ao longo do tempo de processo, a fim de considerá-lo com fidelidade.

O principal objetivo desta simulação foi de avaliar o comportamento da temperatura e da letalidade ao tratamento térmico durante a partida do equipamento.

Como pode ser observado nas Tabelas 5.8 a 5.11, os testes com perturbações no sistema foram: variação na vazão da utilidade de aquecimento, na temperatura de entrada da água quente e do leite, na concentração de micro-organismos na entrada do produto cru e comparação entre as vazões. Essas condições de simulação foram impostas ao sistema de modo a estudar e avaliar o comportamento dos modelos desenvolvidos e do processo em questão, tendo isso como objetivo geral de todas as simulações. 
Tabela 5.8 - Parâmetros das simulações com perturbações na vazão de água quente.

\begin{tabular}{c|ccccc}
\hline \multirow{2}{*}{ Parâmetros } & \multicolumn{5}{|c}{ Tempo de processo (s) } \\
\cline { 2 - 6 } & $0-60$ & $60-360$ & $360-660$ & $660-960$ & $960-1260$ \\
\hline$\dot{m}_{\text {leite }}(\mathrm{L} / \mathrm{h})$ & 20,0 & 20,0 & 20,0 & 20,0 & 20,0 \\
$\dot{m}_{\text {água,fria }}(\mathrm{L} / \mathrm{h})$ & 60,0 & 60,0 & 60,0 & 60,0 & 60,0 \\
$\dot{m}_{\text {água,quente }}(\mathrm{L} / \mathrm{h})$ & 60,0 & 100,0 & 60,0 & 20,0 & 60,0 \\
\hline
\end{tabular}

As condições da simulação da perturbação do sistema devido às mudanças na vazão da água de aquecimento são mostradas na Tabela 5.8. Durante os primeiros $60 \mathrm{~s}$ de tempo de processo, não perturbação no mesmo, estando a pasteurização em estado estacionário. A partir do instante $t=60 \mathrm{~s}$ até $t=360 \mathrm{~s}$ ocorre a primeira perturbação no sistema, sendo, neste caso, aumento na vazão da utilidade de aquecimento de $60 \mathrm{~L} / \mathrm{h}$ para $100 \mathrm{~L} / \mathrm{h}$, para que o fenômeno possa ser estudado e o modelo testado. Entre os instantes $t=360 \mathrm{~s}$ até $t=660 \mathrm{~s}$, o processo é levado ao seu estado anterior à perturbação. Na sequência, entre os instantes $t=660 \mathrm{~s}$ até $t=$ $960 \mathrm{~s}$, nova variação na vazão da água de aquecimento é gerada, de $60 \mathrm{~L} / \mathrm{h}$ para 20 $\mathrm{L} / \mathrm{h}$, até que, após 300 segundo de tempo de processo, o estabelecimento da condição padrão é definido.

Um dos objetivos desta simulação foi avaliar o comportamento da temperatura e da letalidade no tratamento térmico ao longo do equipamento em relação à vazão da utilidade de aquecimento, avaliando a resposta do modelo e situações parcialmente possíveis de falha de um processo convencional de pasteurização de leite.

Tabela 5.9 - Parâmetros da simulação com perturbações na temp. de água quente.

\begin{tabular}{c|ccccc}
\hline \multirow{2}{*}{ Parâmetros } & \multicolumn{5}{|c}{ Tempo de processo (s) } \\
\cline { 2 - 6 } & $0-60$ & $60-360$ & $360-660$ & $660-960$ & $960-1260$ \\
\hline$T_{\text {in,água quente }}\left({ }^{\circ} \mathrm{C}\right)$ & 90,0 & 84,0 & 90,0 & 96,0 & 90,0 \\
$T_{\text {in,água fria }}\left({ }^{\circ} \mathrm{C}\right)$ & 5,0 & 5,0 & 5,0 & 5,0 & 5,0 \\
$T_{\text {in,leite cru }}\left({ }^{\circ} \mathrm{C}\right)$ & 10,0 & 10,0 & 10,0 & 10,0 & 10,0 \\
\hline
\end{tabular}

Este cenário de simulação teve como propósito entender o comportamento da temperatura e da letalidade no tratamento térmico frente às perturbações na temperatura de entrada da utilidade de aquecimento ao longo do processo. 
Tabela 5.10 - Parâmetros da simulação com perturbações na temp. do leite cru.

\begin{tabular}{c|ccccc}
\hline \multirow{2}{*}{ Parâmetros } & \multicolumn{5}{|c}{ Tempo de processo (s) } \\
\cline { 2 - 6 } & $0-60$ & $60-360$ & $360-660$ & $960-660$ & $960-1260$ \\
\hline$T_{\text {in,água quente }\left({ }^{\circ} \mathrm{C}\right)}$ & 90,0 & 90,0 & 90,0 & 90,0 & 90,0 \\
$T_{\text {in,água fria }}\left({ }^{\circ} \mathrm{C}\right)$ & 5,0 & 5,0 & 5,0 & 5,0 & 5,0 \\
$T_{\text {in,leite cru }}\left({ }^{\circ} \mathrm{C}\right)$ & 10,0 & 17,0 & 10,0 & 1,0 & 10,0 \\
\hline
\end{tabular}

Fonte: elaboração do autor (2016).

As Tabelas 5.9 e 5.10 fornecem os valores dos parâmetros operacionais usados nos cenários de perturbações na temperatura de entrada da água de aquecimento e do leite cru durante a sua pasteurização. As variações seguem o mesmo racional da Tabela 5.7, isto é, processamento em condição sem perturbação, aumento no valor da variável em estudo (temperatura da água e do leite), volta da condição inicial, diminuição da variável e novamente volta da condição inicial.

Como objetivo principal, este cenário buscou entender o comportamento da temperatura e da letalidade no tratamento térmico ao longo do equipamento quando mudanças na temperatura de entrada do leite cru eram observadas em sua pasteurização, com o intuito de simular possíveis desvios e variações de processo.

Tabela 5.11 - Parâmetros da simulação com perturbações na concentração microbiana da bactéria $C$. burnetti no leite cru.

\begin{tabular}{c|ccccc}
\hline \multirow{2}{*}{ Parâmetros } & \multicolumn{5}{|c}{ Tempo de processo (s) } \\
\cline { 2 - 6 } & $0-60$ & $60-360$ & $360-660$ & $960-660$ & $960-1260$ \\
\hline$T_{\text {in,leite cru }}\left({ }^{\circ} \mathrm{C}\right)$ & 10,0 & 10,0 & 10,0 & 10,0 & 10,0 \\
$C_{\text {in,leite }}(\mathrm{UFC} / \mathrm{mL})$ & $1 \times 10^{5}$ & $1 \times 10^{8}$ & $1 \times 10^{5}$ & $1 \times 10^{2}$ & $1 \times 10^{5}$ \\
\hline
\end{tabular}

Fonte: elaboração do autor (2016).

A fim de estudar o cenário de variação do sistema devido ao aumento da concentração microbiana do leite cru, tem-se os parâmetros da Tabela 5.11. Novamente, o processo é definido em sua condição padrão (concentração inicial de 1 $\times 10^{5} \mathrm{UFC} / \mathrm{mL}$ ) por 60 segundos de processo, seguido de aumento e diminuição desta variável. Ou seja, a fim de avaliar os efeitos de uma contagem microbiológica maior e menor do que a condição inicial, tem-se essas perturbações no processo. 
As perturbações na concentração inicial da $C$. burnetti no leite cru visam observar como é a resposta da letalidade do processo ao longo e ao final da pasteurização do produto a fim de testar o modelo e possíveis oscilações de qualidade do leite.

Os valores operacionais usados na simulação do processo de pasteurização do leite, em estado estacionário, sem perturbações ou variações no sistema, são vistos na Tabela 5.12.

Este cenário teve como propósito representar o processo em sua condição normal, estando estabilizado e com as variáveis operacionais o mais próximo do set point (valor pré-determinado) do sistema.

Tabela 5.12 - Parâmetros utilizados na simulação do processo estacionário.

\begin{tabular}{cc}
\hline Parâmetros & Valores \\
\hline$\dot{m}_{\text {leite }}(\mathrm{L} / \mathrm{h})$ & 20,0 \\
$\dot{m}_{\text {utilidades }}(\mathrm{L} / \mathrm{h})$ & 60,0 \\
$T_{\text {in,leite cru }}\left({ }^{\circ} \mathrm{C}\right)$ & 10,0 \\
$T_{\text {in,água fria }}\left({ }^{\circ} \mathrm{C}\right)$ & 5,0 \\
$T_{\text {in,água quente }}\left({ }^{\circ} \mathrm{C}\right)$ & 90,0 \\
$C_{\text {in,leite }}(\mathrm{UFC} / \mathrm{mL})$ & $1,0 \times 10^{5}$ \\
\hline
\end{tabular}

As condições usadas nas simulações do processo estacionário em quatro diferentes vazões da utilidade de aquecimento são mostradas na Tabela 5.13.

Estas simulações buscam compreender como é o histórico e perfil de temperatura do leite e da letalidade no tratamento térmico ao longo do tempo de processo no equipamento e em cada seção.

Tabela 5.13 - Parâmetros das simulações para comparação entre quatro diferentes vazões da utilidade de aquecimento.

\begin{tabular}{ccccc}
\hline Parâmetros & Teste 1 & Teste 2 & Teste 3 & Teste 4 \\
\hline$\dot{m}_{\text {água,fria }}(\mathrm{L} / \mathrm{h})$ & 60,0 & 60,0 & 60,0 & 60,0 \\
$\dot{m}_{\text {água,quente }}(\mathrm{L} / \mathrm{h})$ & 30,0 & 60,0 & 90,0 & 120,0 \\
\hline
\end{tabular}

Esse cenário tem como finalidade avaliar como é o efeito de diferentes vazões da utilidade de aquecimento na temperatura e letalidade do processo ao longo do 
tempo. Ou seja, avaliar possíveis variações de processo em estado dinâmico apenas mediante às oscilações na água de aquecimento do produto.

A Tabela 5.13 fornece informações do mesmo cenário da Tabela 5.12. Contudo, a única diferença é que esse mesmo cenário foi simulado quatro vezes, considerando quatro diferentes vazões para água de aquecimento, para estudar como esse parâmetro afeta o processo de pasteurização do leite.

Para este último caso de perturbação na pasteurização do produto, até o instante $t=60 \mathrm{~s}$ o processo se mantém em sua condição normal. Durante os intervalos dos instantes $t=60 \mathrm{~s}$ e $t=360 \mathrm{~s}$ e $t=960 \mathrm{~s}$ e $t=1260 \mathrm{~s}$, houve perturbação de aumento e diminuição, respectivamente, em dois parâmetros operacionais: temperatura e vazão da água quente. Essas perturbações têm como intuito avaliar os modelos desenvolvidos e os efeitos no processo de pasteurização do leite, tendo como base as possíveis variações as quais as indústrias de laticínios estão sujeitas diariamente.

Tabela 5.14 - Parâmetros da simulação com perturbações na vazão da utilidade de aquecimento e na temperatura do leite e da água de aquecimento.

\begin{tabular}{c|ccccc}
\hline \multirow{2}{*}{ Parâmetros } & \multicolumn{5}{|c}{ Tempo de processo (s) } \\
\cline { 2 - 6 } & $0-60$ & $60-360$ & $360-660$ & $960-1260$ & $1260-1560$ \\
\hline$T_{\text {in,leite cru }\left({ }^{\circ} \mathrm{C}\right)}$ & 10,0 & 15,0 & 10,0 & 5,0 & 10,0 \\
$T_{\text {in,água quente }}\left({ }^{\circ} \mathrm{C}\right)$ & 90,0 & 95,0 & 90,0 & 85,0 & 90,0 \\
$\dot{m}_{\text {água,quente }}(\mathrm{L} / \mathrm{h})$ & 60,0 & 70,0 & 60,0 & 50,0 & 60,0 \\
\hline
\end{tabular}

A simulação com perturbações concomitantes nessas variáveis de processo tem como principal objetivo estudar os seus efeitos somados, ao longo do tratamento térmico, na temperatura do leite e em sua inocuidade, para testar o modelo desenvolvido e simular possíveis variações de processos industriais.

Com o intuito de simular às perturbações no sistema, a fim de avaliar o comportamento das principais variáveis de estudo do processo, novos valores eram inseridos no algoritmo do programa, no software gPROMS.

A finalidade em desenvolver um modelo dinâmico em malha aberta é que ele possibilite o ajuste de um controlador de processo. Em outras palavras, como a rotina industrial dificulta avaliar essas perturbações, fez-se as simulações de todos os cenários computacionalmente. 
Os períodos utilizados nos diferentes cenários do estudo de caso foram baseados nos tempos necessários para que os perfis e históricos de temperatura, letalidade e concentração microbiana atingissem o estado estacionário, possibilitando um melhor entendimento dos processos. Para isso, foram realizadas simulações prévias.

A definição das temperaturas da utilidade de aquecimento e do leite cru, concentração microbiana inicial no produto e vazão da água quente foram escolhidas de forma a possibilitar variações significativas nos perfis e históricos das variáveisresposta, mostradas nos gráficos da seção de Resultados e Discussão, como forma de estudar os efeitos na pasteurização sujeita às perturbações no sistema. Ao mesmo tempo, considerando de modo forçado possíveis condições extremas de desvio ou falha de processo industrial em uma rotina fabril.

Para a realização da modelagem empírica do efeito da incrustação do leite no equipamento (equações 4.67 e 4.68) considerou-se um período de indução da incrustação do produto nas placas do PHE. Ou seja, para o leite integral, em trocador de calor a placas, é igual a $1800 \mathrm{~s}\left(t_{f o}\right)$ de acordo com Tejeda (2003). Outro parâmetro desta modelagem, segundo Tejeda (2003), é o fator de incrustação máximo, o qual é equivalente a $2,80 \times 10^{-4} \mathrm{~K} \cdot \mathrm{m}^{2} / \mathrm{W}\left(R_{\operatorname{Max}}\right)$, o qual representa o limite máximo do fator de incrustação do produto. Estes valores estão próximos a outros autores, mas não iguais, pois, de acordo com as condições do processo, do tipo de produto, equipamento, entre outras variáveis, estes valores serão diferentes (BENNETT, 2007; BERGMAN et al., 2011). O valor do parâmetro da constante de velocidade cinética da incrustação $\left(\alpha_{f}\right)$ foi determinado experimentalmente por Gutierrez (2013), em pasteurizador a placas com leite bovino, sendo igual a 1380 1/s, o que está próximo do valor encontrado por Bennett (2007).

Augustin et al. (2007) encontraram valores entre $5,5 \times 10^{-4} \mathrm{~m}^{2} . \mathrm{K} / \mathrm{W}$ e $4,5 \times 10^{-4}$ $\mathrm{m}^{2}$.KM para solução de whey protein em um estudo de incrustação de leite bovino em superfície de aço inoxidável para temperatura de processo abaixo de $100^{\circ} \mathrm{C}$.

Neste trabalho, esses parâmetros empíricos $\left(\alpha_{f}, R_{\operatorname{Max}}\right.$ e $\left.t_{f o}\right)$ foram ajustados em planilha eletrônica em Excel após os ensaios laboratoriais (seção 5.6.2), sendo isso mostrado na seção de validação experimental da incrustação (seção 6.4.1).

Para este caso, o tempo de simulação total foi equivalente a 8,85 horas a fim de operar próximo às condições das indústrias lácteas que, geralmente, realizam o 
processo de limpeza industrial - CIP - após esse período de operação, embora estes valores possam variar (BEARD et al., 2007; REINEMANN et al., 2003).

Os parâmetros e variáveis do processo, leite e água, tais como $\operatorname{Re}, \operatorname{Pr}, \mathrm{Nu}, h_{i}$, $U_{i}, \alpha, \tau, z, C p, \mu, \rho$ e assim por diante, foram determinados individualmente para o tubo de retenção e suas conexões, as seções: aquecimento, regeneração e resfriamento. Tanto os resultados obtidos pela simulação em gPROMS quanto os parâmetros e variáveis calculados neste trabalho, foram realizados no software Excel 2013 (MICROSOFT ${ }^{\circledR}$, USA).

Todas as simulações foram realizadas com malha de controle aberta, ou seja, sem controle de temperatura na saída do tubo de retenção devido à atuação de controlador PID. Então, foi considerado que a válvula diversora de fluxo do equipamento permaneceu fechada todo o tempo, possibilitando a realização do estudo do processo.

\subsection{Validação do Processo Sujeito à Incrustação}

Neste item são descritos os materiais e metodologias usados na validação dos perfis de temperatura da pasteurização sujeita à incrustação, da quantidade de material aderido no equipamento, variação da troca de calor do processo, no ajuste experimental do modelo de incrustação empírico usado e em sua simulação.

\subsubsection{Ensaios Experimentais}

O equipamento utilizado para realização dos ensaios experimentais, para a validação dos resultados simulados, foi o mesmo pasteurizador usado no estudo de caso, sendo ele citado na seção 5.1 (equipamento avaliado).

A Figura 5.3 mostra o conjunto completo (pasteurizador e sistema de aquisição de temperatura) durante os ensaios experimentais, na partida com água.

Para aquisição dos dados de temperatura em tempo real, usou-se o equipamento Compact DAQ-9172 (National Instruments, USA) com três módulos NI9211 para termopares. O sistema é composto por um conjunto de 12 termopares de junta exposta com cabo 24AWG (IOPE, Brasil) e adaptador PI08 S /8" (J h Guest, UK). O software usado para processamento destes dados foi o LabView 8.6 (National 
Instruments, USA). Todos os termopares utilizados foram calibrados antes dos testes para a faixa de trabalho de 0 a $90^{\circ} \mathrm{C}$.

Figura 5.3 - Sistema de aquisição de temperatura do processo ao longo do funcionamento do pasteurizador durante os ensaios experimentais.

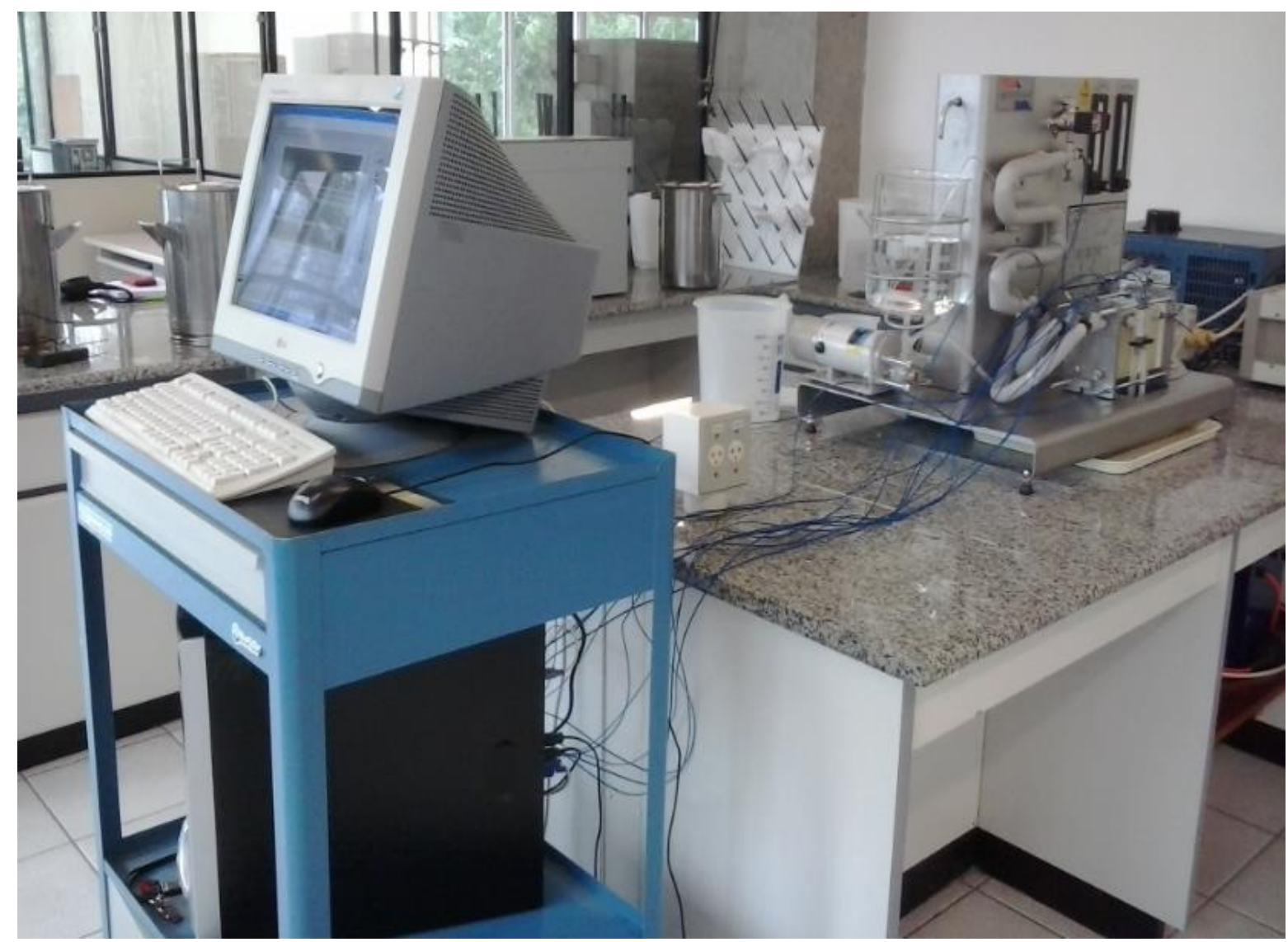

Fonte: elaboração do autor (2016).

O produto da pasteurização foi uma solução incrustante simulada ao leite bovino, sendo composta por: água destilada + proteína láctea WPI + cloreto de cálcio $\left(\mathrm{CaCl}_{2}\right)$. Optou-se por esta combinação a fim de facilitar os ensaios e padronizar o produto, uma vez que o leite é uma substância muito complexa e com certa variabilidade.

A proteína usada é oriunda do produto isolado proteico de soro de leite em pó do fabricante Arla Foods Inc. (procedência da Dinamarca), denominado como Lacprodan DI-9224, apresentando 92 \% de proteína e 0,2 \% de gordura e lactose.

De acordo com Gutierrez (2015), para o desenvolvimento da solução incrustante simulada ao leite bovino, baseou-se na composição média de proteínas do leite, que é, em média, 3,5 \% para leite integral (relação mássica), sendo $20 \%$ de proteínas do soro do leite (fração proteica de maior influência na incrustação do produto). Em 
termos de sólidos solúveis, é composta, majoritariamente, pela proteína $\beta$ lactoglobulina e foi utilizada proteína isolada do soro de leite (do inglês, Whey Protein Isolate ou WPI) em pó, de uma marca comercial brasileira. Fez-se a diluição da proteína em pó em água destilada, numa concentração de 7,28 g/L, mais $0,58 \mathrm{mM}$ de cálcio por litro (GUTIERREZ, 2015).

Os ensaios experimentais para validação dos perfis de temperatura do produto para os cenários de partida do equipamento e perturbações nas variáveis operacionais do processo não foram realizados uma vez que estas validações já foram conduzidas por Gutierrez (2013), neste mesmo equipamento. A validação dos perfis de concentração microbiana e enzimática, em estado estacionário, também não foram conduzidas neste trabalho, pois já foram estudadas por Benze (2013) e Aguiar (2009), respectivamente, também neste mesmo pasteurizador.

De maneira geral, para o cálculo do coeficiente global de transmissão de calor entre o fluido de aquecimento e o produto, com $\left(U_{t}\right)$ e sem incrustação $(U)$, no PHE de aquecimento, a partir dos dados experimentais e simulados, fez-se uso das equações que seguem:

$$
\dot{Q}(t)=U_{t}(t) \cdot A_{P} \cdot \Delta T_{l m}(t)
$$

em que $\Delta T_{l m}$ representa a representa a média logarítmica das diferenças de temperatura entre fluidos quente e frio $\left({ }^{\circ} \mathrm{C}\right), A_{P}$ representa a área de troca térmica total e $\dot{Q}(t)$ representa a taxa de calor trocado (W) no instante $t$ do processo. Matematicamente, $\Delta T_{l m}$ é representado como:

$$
\Delta T_{\text {lm }}=\frac{\left(T_{\text {ent }, \text { frio }}-T_{\text {sai, quente }}\right)-\left(T_{\text {ent,quente }}-T_{\text {sai,frio }}\right)}{\ln \left[\frac{\left(T_{\text {ent }, \text { frio }}-T_{\text {sai }, q u e n t e}\right)}{\left(T_{\text {ent }, \text { quente }}-T_{\text {sai }, \text { frio }}\right)}\right]}
$$

Ao mesmo tempo, considerando o balanço de energia nos canais, entre as placas do PHE, levando em conta que não há mudança de fase, tem-se:

$$
\dot{Q}(t)=\dot{m}_{i} \cdot C p_{i}(t) \cdot\left[T_{\text {sai }}(t)-T_{\text {ent }}(t)\right]
$$


Por fim, igualando as duas equações e isolando o coeficiente global de transmissão de calor, ter-se-á:

$$
U_{t}(t)=\frac{\dot{m}_{i} \cdot C p_{i}(t) \cdot\left[T_{\text {sai }}(t)-T_{\text {ent }}(t)\right]}{A_{P} \cdot \Delta T_{l m}(t)}
$$

A partir da equação 5.13 é possível determinar o valor experimental do coeficiente global de transferência de calor do processo em função do tempo.

Foram realizados dois ensaios experimentais para validação do modelo de incrustação, sendo um pré-teste (teste 1) para estudo da viabilidade da deposição de material nas placas (teste qualitativo) e o teste (teste 2) quantitativo para geração de dados, ambos com solução proteica láctea (algo próximo a um fluido simulado ao leite) para facilitar a padronização e o controle dos ensaios. Os componentes químicos bem como as suas quantidades são mostradas na Tabela 5.15.

Para o teste 2, o qual foi usado na geração de dados experimentais para validação da simulação do modelo, foi realizada a recirculação da solução incrustante simulada ao leite bovino após 1,3 horas (4680 s) do início do processo de pasteurização, em decorrência da baixa quantidade de material obtido para os ensaios, similar a Gutierrez (2015).

Tabela 5.15 - Componentes usados nos ensaios de validação da incrustação.

\begin{tabular}{cccc}
\hline Teste & Componentes & Concentração & Volume total $(\mathrm{L})$ \\
\hline 1 & $\mathrm{WPI}$ & $8,28 \mathrm{~g} / \mathrm{L}$ & 12,1 \\
2 & $\mathrm{WPI}+\mathrm{CaCl}_{2}$ & $7,28 \mathrm{~g} / \mathrm{L}+0,058 \mathrm{mM} / \mathrm{L}$ & 30,0 \\
\hline
\end{tabular}

As condições operacionais destes experimentos são mostradas na Tabela 5.16, sendo que, em todos os casos, o processo foi iniciado a partir do estado estacionário com água.

Para todos os testes, as vazões das utilidades e do produto foram definidas em seu valor nominal, $60 \mathrm{~L} / \mathrm{h}$ e $20 \mathrm{~L} / \mathrm{h}$, respectivamente, e em ambos os testes, houve recirculação do fluido simulado, com o intuito de avaliar se essa recirculação de produto afeta o processo. 
Tabela 5.16 - Parâmetros operacionais dos ensaios de validação da incrustação.

\begin{tabular}{ccccc}
\hline \multirow{2}{*}{ Teste } & \multicolumn{3}{c}{ Temperatura inicial $\left({ }^{\circ} \mathrm{C}\right)$} & \multirow{2}{*}{ Tempo $(\mathrm{h})$} \\
\cline { 2 - 4 } & Aquecimento & Produto & Resfriamento & \\
\hline 1 & 95,0 & 18,4 & 5,7 & 3,6 \\
2 & 95,1 & 16,2 & 2,4 & 3,3 \\
\hline
\end{tabular}

Apenas no teste 2 se fez uso de cloreto de cálcio $\left(\mathrm{CaCl}_{2}\right)$, pois, após o pré-teste (teste 1; sem $\mathrm{CaCl}_{2}$ ), a solução não incrustou significativamente nas placas do PHE. Então, foi adicionado o cloreto de cálcio à solução, o que tornou a sua natureza físicoquímica mais próxima ao leite bovino e por ser um dos componentes mais importantes para o fenômeno da incrustação, como feito por Erabit et al. (2014).

Com base em Gutierrez (2015), as amostras foram preparadas com 24 horas de antecedência aos ensaios, mantendo-se refrigeradas. Inicialmente a massa de proteína foi pesada e dissolvida em água destilada a $51{ }^{\circ} \mathrm{C}$, a fim de favorecer a dissolução do pó, mas sem desnaturar as proteínas. O procedimento foi conduzido sob agitação contínua de 1500 RPM Agitador (Fisatom, BR), por 30 minutos, com uso de agitador eletrônico, com controle de temperatura. Em seguida, fez-se a adição gradual do cloreto de cálcio. Após a dissolução completa da proteína, em tanques de aço inoxidável, esperou-se o resfriamento da solução até a temperatura ambiente. Em seguida, colocou-se essa solução na câmara de resfriamento até o atingimento da temperatura de $18^{\circ} \mathrm{C}$ e sua estabilização por 20 horas.

Antes da partida do pasteurizador, a qual foi conduzida apenas com água destilada, todas as placas dos PHEs foram identificadas e pesadas em balança analítica antes e após os ensaios, para registro de massa incrustrada posteriormente, como pode ser visto na Figura 5.4.

Após todos os testes, a massa incrustada na superfície das placas foi quantificada como material úmido e seco. Colocou-se as placas numa estufa à vácuo, a $70^{\circ} \mathrm{C}$ (Solab, BR) por 4 horas, para eliminar o conteúdo de umidade na massa incrustada. Após a retirada da estufa, todas foram pesadas em balança analítica e os resultados foram registrados. 
Figura 5.4 - Identificação das placas dos PHEs e inserção dos termopares

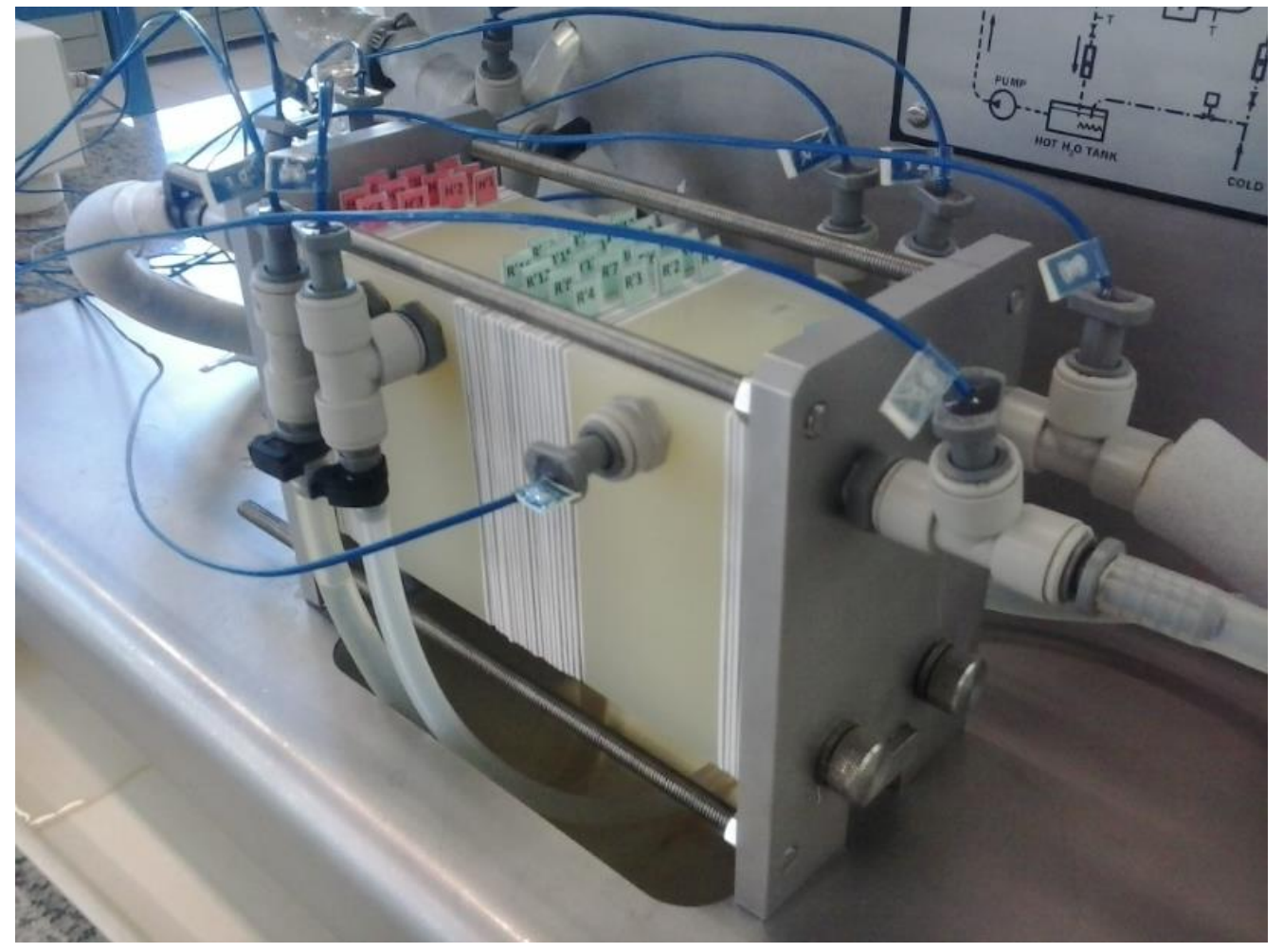

Fonte: elaboração do autor (2016).

O processo foi conduzido em malha aberta (sem PID), sendo, então, controladas apenas as temperaturas de entrada das utilidades de aquecimento e resfriamento, assim como para a simulação em estudo de caso.

\subsubsection{Ajuste do Modelo Empírico}

A partir dos resultados experimentais do teste 2 (dados de temperatura ao longo do tempo), foram calculados, em planilha Excel, os valores experimentais do coeficiente global de troca térmica $\left[U_{t}(t)\right]$ da seção de aquecimento entre a utilidade quente e a solução simulada ao leite, bem como das propriedades termofísicas, pela equação 5.13.

Após isso, fez-se o cálculo dos valores teóricos do coeficiente global de troca térmica $\left[U_{t}(t)\right]$ da seção de aquecimento entre a utilidade e a solução pela equação 4.65 , usando os parâmetros do modelo de incrustação, $R_{\max }, \alpha_{f}$ e $t_{f o}$, mostrados na seção 5.5 . 
Em posse dos dados de coeficiente global de troca térmica teórico e experimental, foi realizado o ajuste dos parâmetros empíricos do modelo de incrustação, $R_{\max }, \alpha_{f}$ e $t_{f o}$, pela técnica de minimização de erro quadrático com auxílio do solver do Excel, através do método GRG não linear.

O fator de incrustação $\left(R_{f}\right)$ experimental e teórico do produto, durante a sua pasteurização, foi calculado de acordo com a equação 4.65 , com base no coeficiente global de troca térmica experimental e no teórico, respectivamente.

\subsubsection{Simulação do Ensaio Experimental}

Em posse dos parâmetros ajustados de incrustação, fez-se uma nova simulação nas mesmas condições operacionais do teste 2, usando o modelo ajustado em Excel, para comparação dos resultados experimentais com os teóricos. Novamente, fez-se o cálculo dos valores médios das propriedades termofísicas dos fluidos em Excel a fim de reduzir o esforço computacional. Todavia, como a solução proteica (láctea) apresentou fração mássica de água igual a 0,9 e também por não possuir todos os componentes do leite bovino, então utilizou-se as equações termofísicas da água.

Para o cálculo teórico da quantidade de massa aderida às placas do PHE da seção de aquecimento $\left(m_{f}\right)$, após a pasteurização sujeita à incrustação, fez-se uso das equações 5.14 e 5.15 .

$$
e_{f}(t)=R_{f}(t) \cdot k_{f}
$$

Então, tem-se:

$$
m_{f}(t)=\rho_{f} \cdot e_{f}(t) \cdot A_{P}
$$

em que $k_{f}$ é igual a 0,5 W/m.K (LECLERCQ-PERLAT, LALANDE, 1991), $\rho_{f}$ é a densidade do material depositado nas placas, sendo igual a $1.030 \mathrm{~kg} / \mathrm{m}^{3}$ (LECLERCQPERLAT, LALANDE, 1991), ambos para leite bovino, $e_{f}(t)$ é a espessura (gramas) da camada incrustada ao longo do tempo e, como aproximação, $A_{P}$ representa a área de troca térmica das placas a qual esteja incrustada. Essa consideração foi feita, pois, após os testes no equipamento, observou-se que a deposição de produto não ocorreu 
em toda a placa, mas apenas em parte de sua área de troca térmica, como pode ser visto na Figura 6.33 do Capítulo 6 (Resultados e Discussão).

A simulação realizada nesta etapa, assim como nos outros cenários, contempla um processo em malha aberta, ou seja, sem a atuação de um controlador. O objetivo de desenvolver o modelo dinâmico em malha aberta é que ele possa ser usado para o ajuste de um controlador de processo. Isto é, os estudos de perturbação não ocorrerem industrialmente, pois o controlador atuaria para minimizar os desvios.

As validações dos perfis de temperatura ao longo do tempo de processo durante a partida do equipamento e para perturbações nas variáveis do sistema, já foram conduzidas por Gutierrez (2013), para este mesmo equipamento, mas considerando água de processo e não leite. A validação temporal dos históricos de letalidade do processo, também em pasteurizador a placas, foi representada pela atividade enzimática da fosfatase alcalina (AGUIAR, 2009). Isso explica o porquê da não validação de todas as simulações realizadas neste trabalho, o qual visa validar e ajustar o modelo para o cenário da incrustação de uma solução de proteína láctea (algo similar a um fluido simulado ao leite bovino, mas não igual). 


\section{RESULTADOS E DISCUSSÃO}

Os resultados das simulações do modelo desenvolvido no Capítulo 4, para as condições específicas citadas no Capítulo 5, e para validação do modelo empírico da incrustação do produto, são mostrados na sequência. Os resultados obtidos nas diversas condições de processo, ao longo do funcionamento do equipamento, são relativos ao histórico de temperatura do leite e das placas do PHE, da concentração do micro-organismo $C$. burnetii e da letalidade ao tratamento térmico, ambos em relação ao tempo e ao espaço. Os resultados são organizados de acordo com as seções: 6.1) partida do processo (estado transiente); 6.2) pasteurização (estacionário); 6.3) perturbações no processo (transiente); 6.4) tratamento térmico sujeito à incrustação do leite 6.5) validação da pasteurização sujeita à incrustação.

\subsection{Partida do Processo}

Os resultados referentes à simulação da partida do pasteurizador são observados nas Figuras 6.1 a 6.5, apresentadas a seguir.

Inicialmente, pela inspeção da Figura 6.1, observa-se as indicações T1, T2, T3, T4, T5, T6, T7 e T8, que correspondem aos pontos representativos do processo de pasteurização, sendo estes já mostrados e descritos na Figura 4.1 e no item 4.3.1, do capítulo da modelagem. A figura é dividida em 3 estágios: processo estacionário isotérmico com água (1), processo transiente com água (2) e transição para leite bovino (3).

Com relação a Figura 6.1, o pasteurizador é inicializado com água de processo (na entrada da seção de regeneração), ao invés de leite, até o instante $t=360 \mathrm{~s}$. Tanto a água de processo quanto as utilidades partem da mesma temperatura a 20 ${ }^{\circ} \mathrm{C}$, sendo esse o estágio 1 . A partir do instante $t=60 \mathrm{~s}$, as utilidades de aquecimento e resfriamento assumem seus valores padrões operacionais, neste caso, $90{ }^{\circ} \mathrm{C}$ e 5 ${ }^{\circ} \mathrm{C}$, respectivamente, sendo esse o estágio 2. Após isso, quando o sistema foi estabilizado, a partir do instante $t=360 \mathrm{~s}$, o processo é operado com leite bovino cru - estágio 3. Com isso, representa-se a rotina industrial de plantas lácteas em geral. 
Figura 6.1 - Histórico de temperatura (do leite e da água) ao longo do tempo de processo da simulação da partida do pasteurizador.

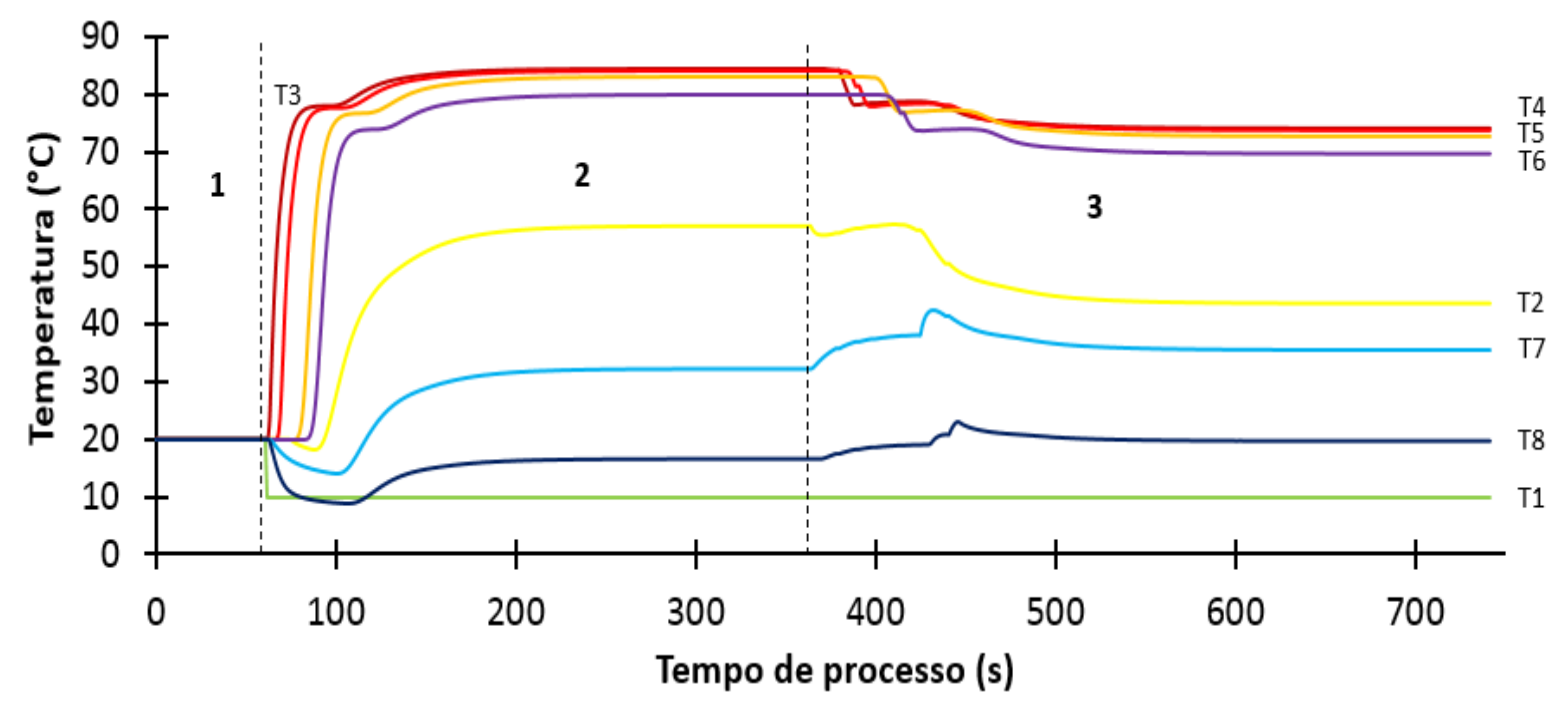

A partida do equipamento se deu no instante $t=0 \mathrm{~s}$, considerando apenas água em todas as seções do pasteurizador e todo o sistema em uma mesma temperatura $\left(20^{\circ} \mathrm{C}\right)$. A primeira perturbação observada na Figura 6.1 é na temperatura de entrada da água de processo, a $10^{\circ} \mathrm{C}(\mathrm{T} 1)$, no estágio 2. Seguindo, outras perturbações também foram observadas nos perfis de temperatura da água de processo, só que nas seções de resfriamento e de aquecimento (T8 e T3), devido ao fato de as utilidades atingirem suas temperaturas padrões de processo.

Observa-se que em T3 (saída do aquecimento) há relativa e curta estabilização do perfil de temperatura, perto do instante $t=90 \mathrm{~s}$. Porém, esse perfil é seguido por um período de elevação até nova estabilização. O mesmo comportamento é observado em T4, T5 e T6, mas com certo atraso devido ao escoamento, ou seja, o tempo que o fluido leva para ir de um ponto ao outro. Já em T2, T7 e T8, também se visualiza perturbações nos perfis de temperatura. Neste caso, tem-se um decaimento seguido de um aumento nos valores de temperatura da água de processo até a estabilização do sistema. Em resumo, estas perturbações ou oscilações estão ligadas ao efeito da seção de regeneração do equipamento e, ao mesmo tempo, devido à combinação dos fatores do tempo espacial do produto dentro do pasteurizador, e às mudanças de temperatura de entrada da água de processo e das utilidades. Ou seja, isso nada mais é que a combinação do efeito da entrada da água de processo quente na regeneração, oriunda da saída da retenção, com a água de processo que entrava a $20^{\circ} \mathrm{C}$ também na regeneração, mas, que agora, entra a $10^{\circ} \mathrm{C}$. 
De acordo com o perfil de temperatura ao longo do processo, é razoável afirmar que o mesmo permaneceu em estado transiente até, aproximadamente, o instante $t=$ $300 \mathrm{~s}$, ou $240 \mathrm{~s}$ de tempo de processo, apresentando a máxima e mais significativa variação nos perfis de temperatura até aproximadamente $o$ instante $t=150 \mathrm{~s}$. Após esse período, nota-se uma estabilização do sistema no estágio 2 ainda com água. É correto afirmar que o processo tendeu ao estado estacionário, pois o perfil de temperatura começou a se manter constante, sendo isso confirmado pela variação da temperatura no tempo, ou seja, $d T /\left.d t\right|_{t=300 s} \approx 0$.

Analisando o processo no estágio 3 , quando o pasteurizador começou a ser alimentado com leite, em vez da água de processo (T1), observa-se as transições entre os perfis de temperatura no intervalo de período do instante $t=360 \mathrm{~s}$ a $t=560$ $s$ até a estabilização do sistema. Embora o leite esteja entrando na mesma temperatura da água de processo, a temperatura das utilidades de aquecimento e resfriamento estejam constantes e a vazão tenha se mantido igual, os perfis de temperatura do produto sofrem variações durante este intervalo de tempo de processo. Esse fenômeno ocorre em razão das propriedades termofísicas do leite e da água serem diferentes.

Para o estágio 2, até o processo atingir o seu estado estacionário, é notável a existência de perturbações nos perfis de temperatura do leite ocasionados pela seção de regeneração, que repercutem nas outras seções do equipamento.

A primeira perturbação é observada em T2 e em T7. Isso é esperado uma vez que ambas representam a saída da regeneração, que é a primeira seção a receber o leite no lugar da água. Após curto intervalo de tempo, variações são notadas em T3, T4, T5 e T6, respectivamente, pois é o tempo que o leite levou para chegar a estas seções do equipamento, enquanto a água de processo sai do sistema, isto é, o tempo espacial de escoamento dos fluidos.

Quando foi constatado o estado estacionário (instante $t=700 \mathrm{~s}$ ), a temperatura máxima do leite é atingida na saída da seção de aquecimento (T3) e equivale a 74,12 ${ }^{\circ} \mathrm{C}$. Contudo, antes do atingimento deste estado, ou seja, durante o regime transiente, a temperatura máxima do leite foi obtida em T5, equivalendo por volta de $82{ }^{\circ} \mathrm{C}$, no instante $t=403 \mathrm{~s}$. Essas altas temperaturas do produto são registradas como consequência da troca térmica do leite frio que entra e da água de processo que sai da regeneração, pois os perfis de temperatura da água são mais acentuados do que do produto devido à capacidade térmica ser mais elevada. 
Os resultados da Figura 6.1 representam a simulação da partida do equipamento com água de processo e depois a transição com leite. De modo diferente, Gutierrez et al. (2014) também fizeram a simulação dinâmica de um pasteurizador a placas em escala laboratorial, pela modelagem matemática fenomenológica, mas partindo o equipamento apenas com água.

O valor de esterilização do tratamento térmico simulado em relação ao tempo de processo, em cada seção e no tudo de retenção do pasteurizador, pode ser visto na Figura 6.2. As indicações L1, L2, L3, L4, L5, L6, L7 e L8 correspondem ao decaimento logarítmico decimal na concentração de micro-organismos na entrada do equipamento, na saída da regeneração, na entrada e na saída da seção de aquecimento, na conexão 1, no tubo de retenção, na conexão 2, na entrada e na saída da seção de resfriamento, respectivamente, correspondendo aos pontos de controle de temperatura indicados na Figura 4.1 e no item 4.3.1, do capítulo de Modelagem. Além disso, de mesmo modo que no caso anterior, os estágios 2 e 3 referem-se ao pasteurizador com água de processo e com leite.

A Figura 6.2 apresenta valores de esterilização acumulados apenas no estágio 3, pois é nesse momento que o pasteurizador é preenchido com leite. Além disso, percebe-se que as primeiras medições são observadas em $L 1$ até $L 7$, nesta exata sequência, o que representa o tempo que o leite leva para preencher todo o equipamento - tempo espacial.

Figura 6.2 - Distribuição da letalidade ao tratamento térmico simulado ao longo do tempo durante a partida pasteurizador com água e leite cru.

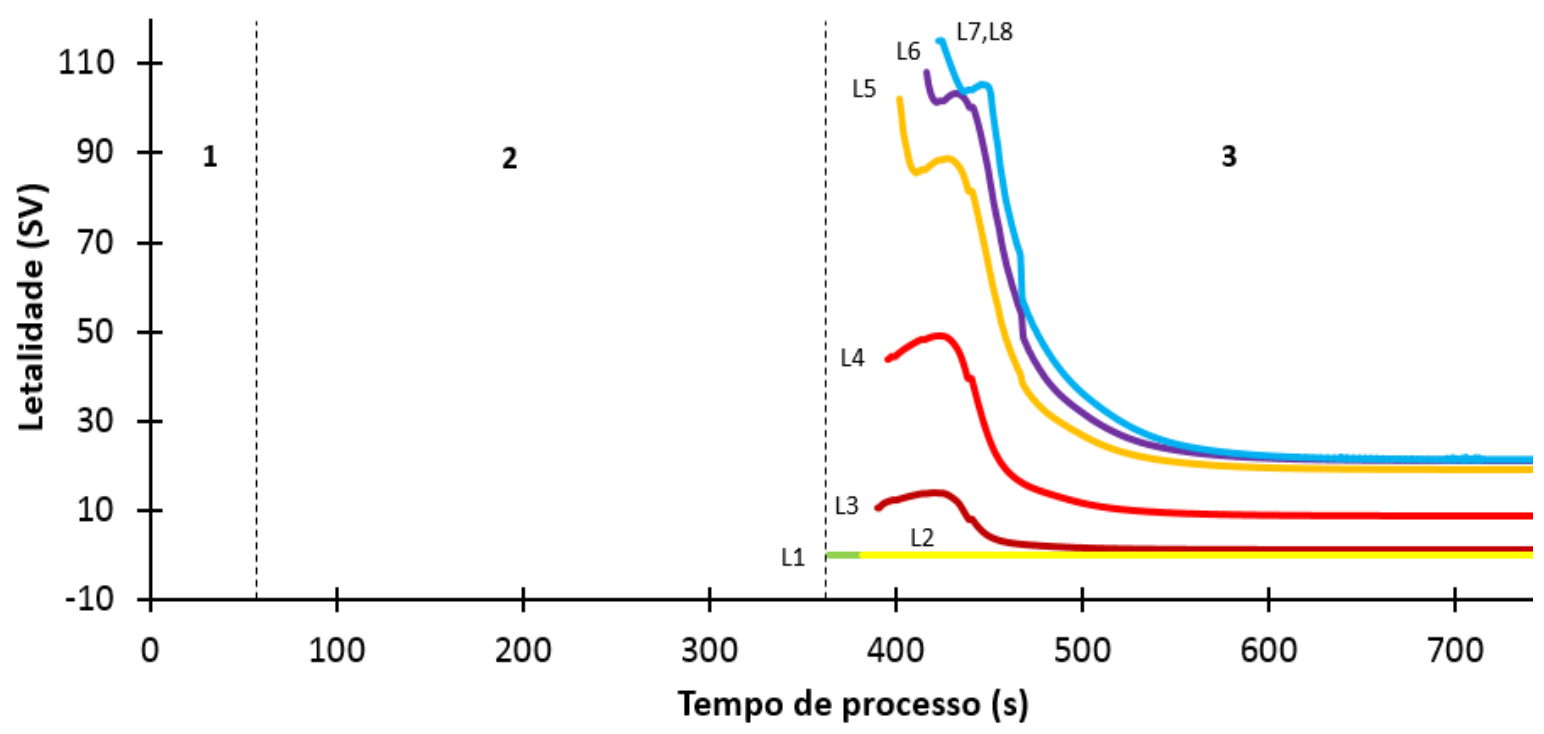


O valor da letalidade em L2 (estágio 3) permanece próximo a 0 ao longo de todo o processo (Figura 6.2), pois a temperatura do leite não é alta o suficiente para causar destruição térmica significativa dos micro-organismos, neste caso, não excedendo 60 ${ }^{\circ} \mathrm{C}$ (Figura 6.1).

Entre os instantes $t=360 \mathrm{~s}$ e $t=450 \mathrm{~s}$, têm-se os maiores valores no decaimento logarítmico decimal na concentração microbiana para L3, L4, L5, L6, L7 e L8 (Figura 6.2). Esses resultados são observados devido às maiores temperaturas do leite neste intervalo de tempo (Figura 6.1), quando ocorre a transição de água para produto.

Ainda sobre $o$ intervalo de instantes $t=360 \mathrm{~s}$ a $t=450 \mathrm{~s}$, percebe-se que cada perturbação acometida no perfil de temperatura de leite (Figura 6.1), resulta em uma perturbação no perfil de letalidade (Figura 6.2), uma vez que a cinética depende da temperatura do leite.

Além disso, durante esse período de tempo de processo, o leite é sobreprocessado, ou seja, a redução da carga microbiana do leite é elevada, chegando até $S V=116$, como consequência das altas temperaturas.

Como na Figura 6.1, o processo atingiu o seu estado estacionário por volta do instante $t=700 \mathrm{~s}$, apresentando decaimento logarítmico decimal final na concentração bacteriana de $S V=21$ e concentração de células viáveis de $C$. burnetti igual a $3,0 \times 10^{-17} \mathrm{UFC} / \mathrm{mL}$ ao final da pasteurização. Nesse sentido, mesmo que a temperatura em T7 nunca seja alta o suficiente para reduzir a contagem de células bacterianas, é em L7 (e L8) que se tem os maiores valores para letalidade. Esse resultado ocorre porque a observação da letalidade é baseada em seu valor acumulado ao longo do processo, naquele instante.

Essa análise é considerada como uma extensão e melhoria de Gutierrez et al. (2014), a qual não levou em conta o efeito da letalidade do tratamento térmico em seu estudo de modelagem, simulação e validação do processo de pasteurização do leite com água.

A Figura 6.3 representa um cenário similar ao da Figura 6.2. A única diferença é que na Figura 6.3, a partida do pasteurizador é simulada diretamente com leite, e não com água de processo e depois leite, similar a Gutierrez et al. (2014), que foi feito diretamente com água. Embora essa prática seja bem menos usual em termos industriais, ela nos fornece informações valiosas em relação à letalidade do processo. 
Pela Figura 6.3, o processo já parte do equilíbrio térmico com leite cru (estágio 2). Comparando os dois cenários (Figuras 6.2 e 6.3), tem-se que o valor final para esterilização bem como a concentração microbiana são os mesmos. Contudo, o tempo que o processo levou para atingir o estado estacionário é diferente. No caso de partida com água de processo e leite, o tempo para atingir o estado estacionário é por volta de $640 \mathrm{~s}$ (instante $t=700 \mathrm{~s}$ ), e o para o caso de partida apenas com leite e de aproximadamente $340 \mathrm{~s}$ (instante $t=400 \mathrm{~s}$ ).

Figura 6.3 - Distribuição da letalidade ao tratamento térmico simulado ao longo do tempo durante partida pasteurizador apenas com leite cru.

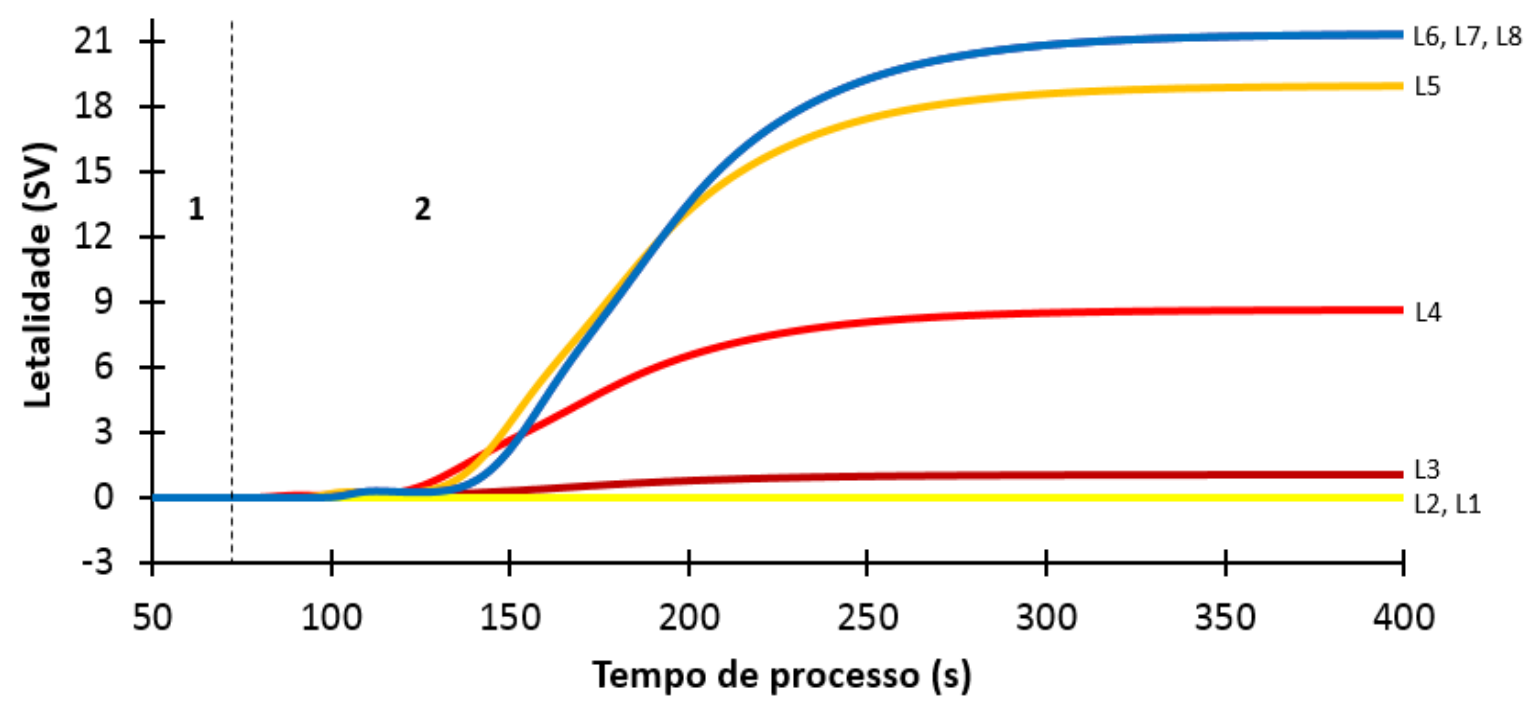

Outra diferença é que, para o caso da Figura 6.3, todo o leite processado do início do processo $(t=60 \mathrm{~s})$ até 0 estado estacionário $(t=400 \mathrm{~s})$, estará subprocessado, ou seja, a redução da concentração microbiana não será suficiente para garantir a inocuidade ao produto. Baseado nisso, as indústrias e cooperativas de laticínios podem fazer utilização da válvula diversora. Ela tem a função de desviar o fluxo de leite subprocessado, durante a partida do equipamento ou quando houver alguma falha no processo ao longo da produção, para ser recirculado, a fim de garantir o seu correto processamento com o objetivo de garantir a inocuidade do produto. $\mathrm{Ou}$ seja, garantindo-se o binômio de tempo e temperatura dimensionado (BYLUND, 1995). Todavia, essa manobra industrial gera maiores custos fabris (BEVIS, 2015), pois o produto já processado estará sendo reprocessado novamente ao invés de se tratar o leite cru. Também há maior perda de qualidade do produto devido à sua exposição ao calor pela segunda vez (FOX e McSWEENEY, 1998; JUNG e FRYER, 
1999; LEWIS e DEETH, 2009). Portanto, é de suma importância o correto dimensionamento e controle do processo, uma vez que o produto subprocessado deverá ser descartado ou reprocessado. De modo contrário, para o caso da Figura 6.2, o leite processado estará mais próximo aos padrões de segurança alimentar e, se estiver dentro da norma da legislação brasileira, não será necessária à sua recirculação ou descarte, pois o valor de $S V$ é maior ao longo de todo o processo de pasteurização no caso da Figura 6.2.

As distribuições de temperatura do leite, da água de processo e do histórico da letalidade, de acordo com o tempo espacial, ao longo das seções e dos tubos do pasteurizador, em vários instantes de processo (partida do equipamento), são mostradas nas Figuras 6.4 e 6.5, respectivamente. Nesse sentido, os números 50, 70, $80 \ldots 500$ e 700 representam os perfis após $50,70,80 \ldots 500$ e 700 segundos durante o tempo de processo, ao longo da partida da pasteurização, em estado transiente. As indicações 1, 2, 3, 4, 5, 6 e 7, correspondem às seções de regeneração (1), aquecimento (2), conexão 1 (3), tubo de retenção (4), conexão 2 (5), regeneração (6) e resfriamento (7), respectivamente.

Figura 6.4 - Evolução dos perfis de temperatura do leite ao longo do tempo espacial durante a partida do pasteurizador em diferentes instantes de processo.

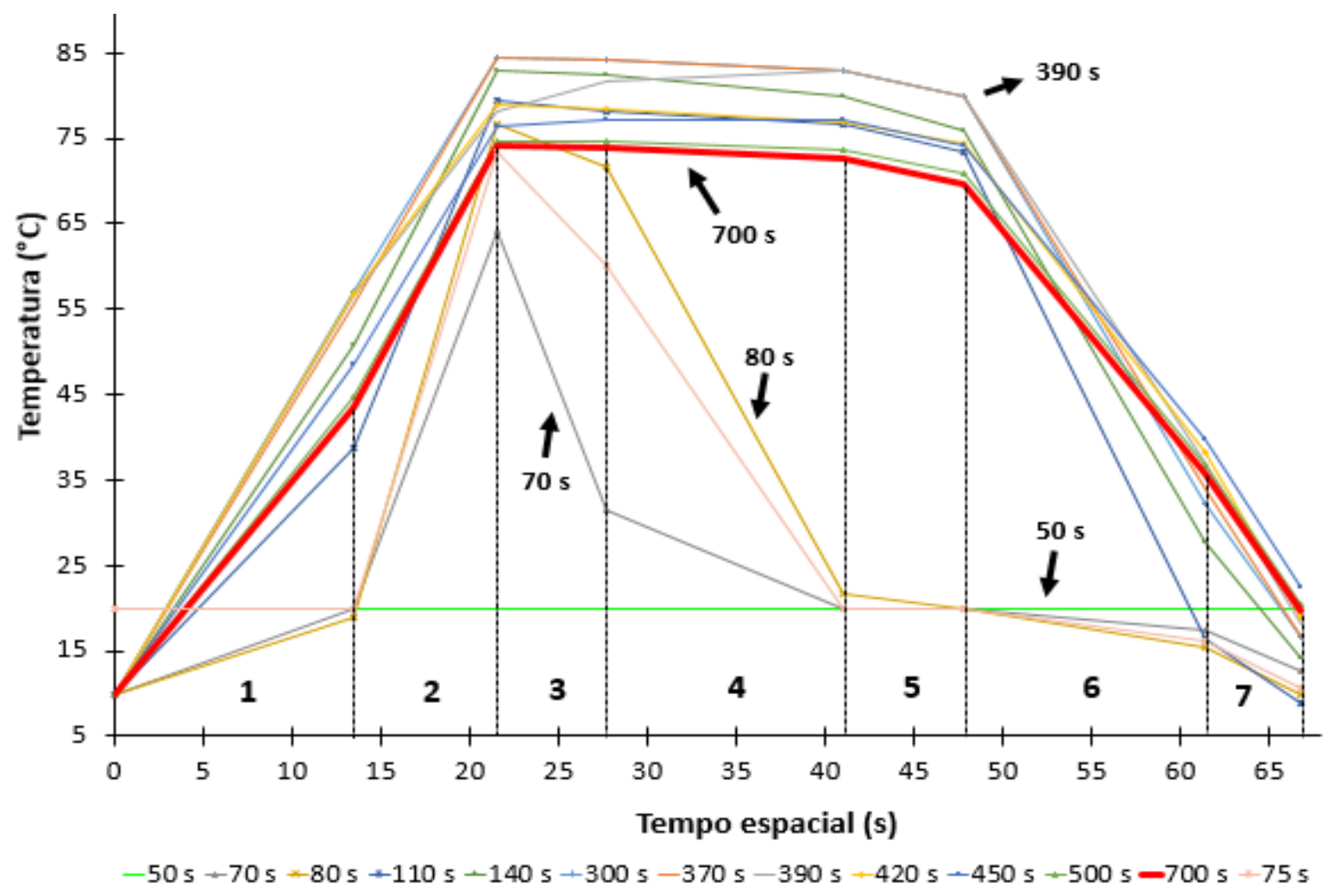


Pela Figura 6.5, fica claro que a temperatura do leite parte de altos valores (390 s) para valores menores, durante a inicialização do pasteurizador (estado transiente), até a sua completa estabilização no estado estacionário (700 s - estacionário). De fato, isso é repercutido nos valores de esterilização comercial $(S V)$ do leite, também indo de maiores valores $(S V>100)$ para menores reduções logarítmicas na concentração microbiana, como visto na Figura 6.5.

Figura 6.5 - Evolução dos perfis de letalidade ao longo do tempo espacial durante a partida do pasteurizador em diferentes instantes de processo.

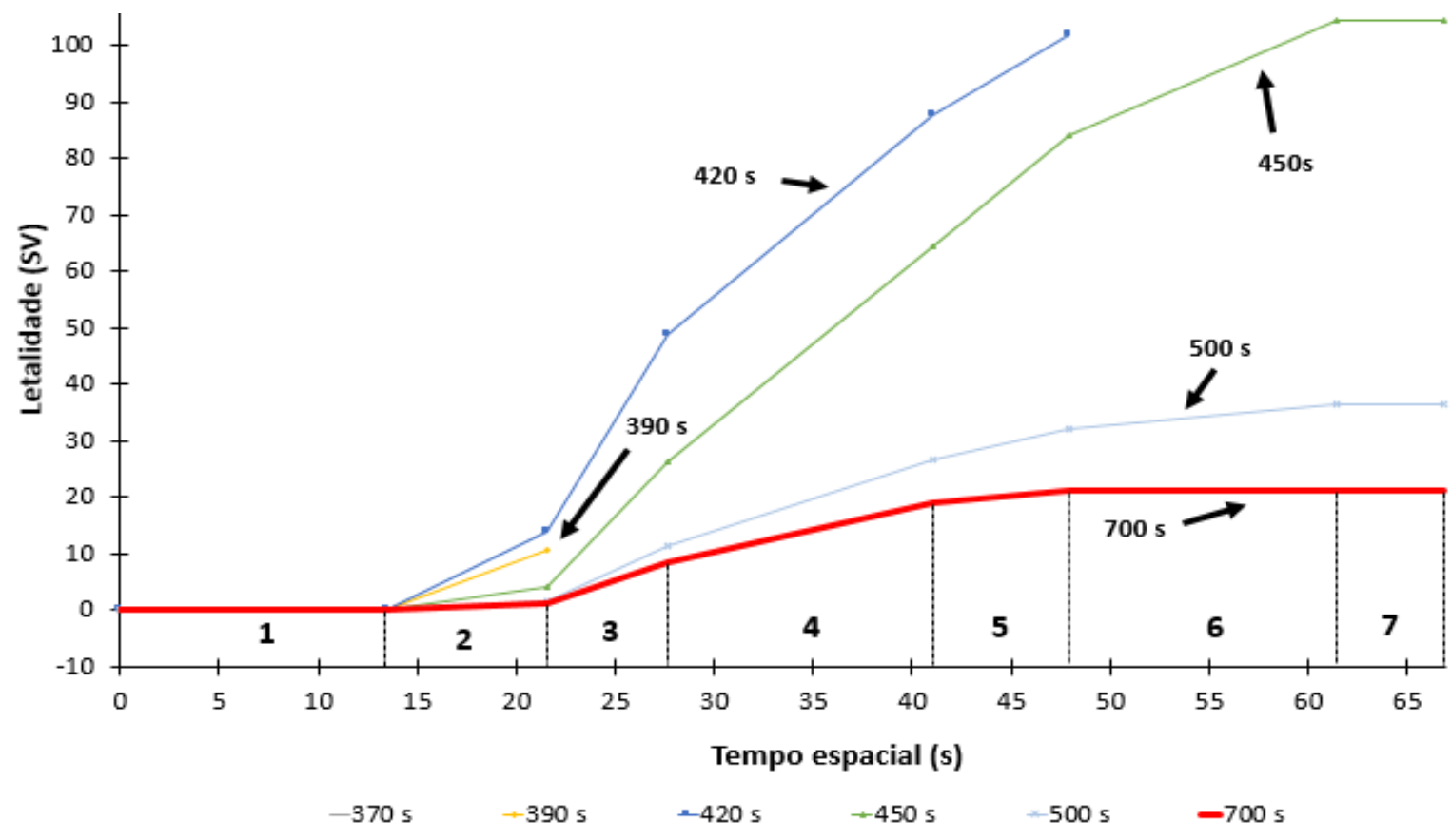

É possível observar a evolução dos perfis de letalidade ao longo do tempo espacial e em relação ao tempo de processo, desde o estado transiente até o estado estacionário (instante $t=700 \mathrm{~s}$ ). No instante $t=390 \mathrm{~s}$, a letalidade é reportada apenas nas seções 1 e 2 . Já no instante $t=420 \mathrm{~s}$, é constatada nas seções $1,2,3$, 4 e 5. A partir do instante $t=450 \mathrm{~s}$, ela é observada em todas as seções do equipamento já que o leite preenche todo o percurso no pasteurizador.

\subsection{Pasteurização no Estado Estacionário}

Os resultados das simulações do processo de pasteurização em estado estacionário são mostrados nas Figuras 6.6 até 6.9, apresentadas a seguir. 
Pela Figura 6.6, tem-se a distribuição de temperatura do leite e do histórico da letalidade ao tratamento térmico avaliado, de acordo com o tempo espacial, ambos ao longo das seções e dos tubos do pasteurizador. Nesse sentido, as indicações 1, 2, 3, 4, 5, 6 e 7, correspondem às seções de regeneração (lado frio), aquecimento, conexão 1, tubo de retenção, conexão 2, regeneração (lado quente) e resfriamento, respectivamente.

Figura 6.6 - Histórico de temperatura e distribuição da letalidade para $C$. burnetii em relação ao tempo espacial do processo de pasteurização do leite.

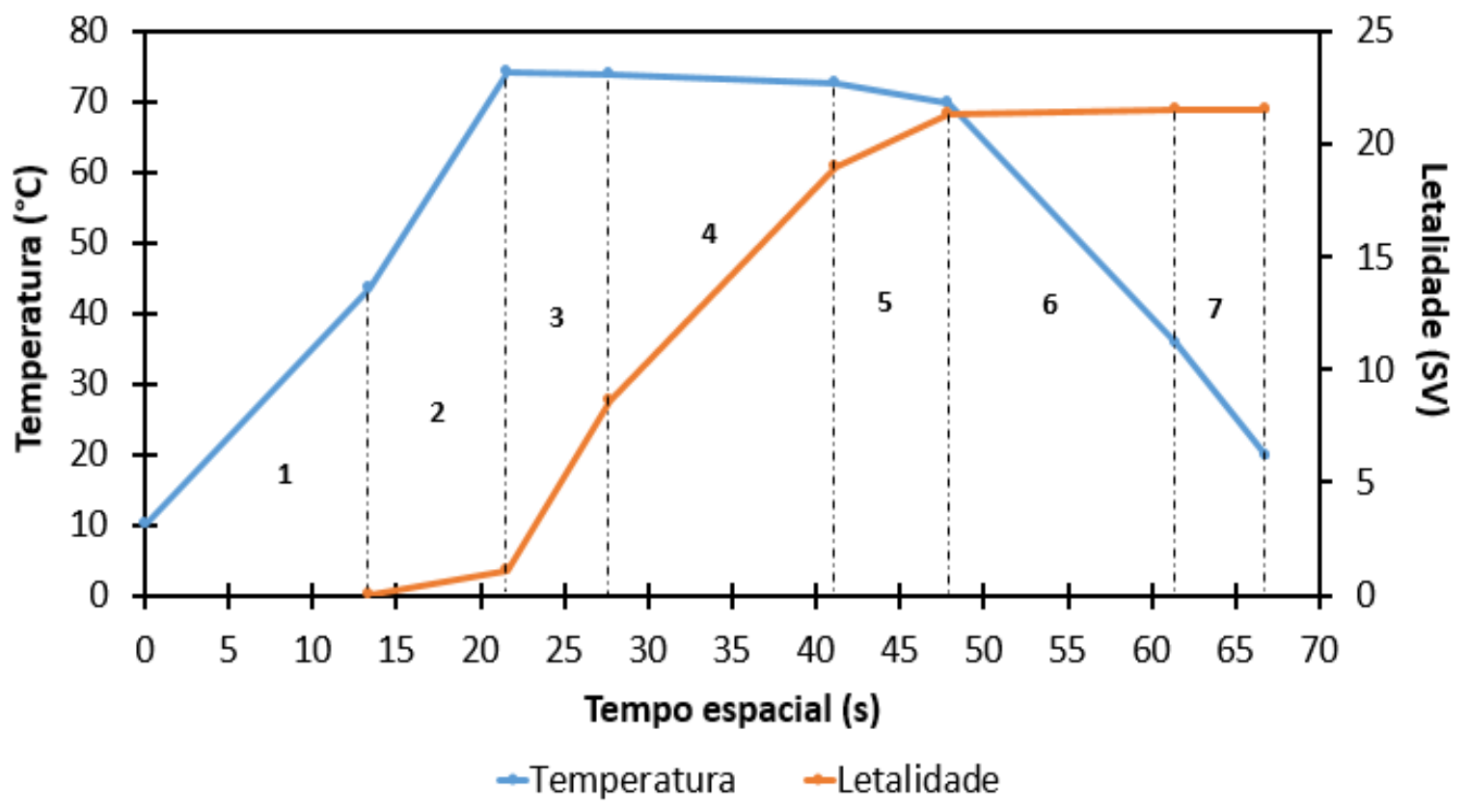

Observando a Figura 6.6, apenas quando a temperatura do leite atinge um valor mínimo $\left(\approx 70{ }^{\circ} \mathrm{C}\right)$, na seção de aquecimento (2), começa a ocorrer o decaimento decimal significativo na concentração da $C$. burnetii, tornando o produto cada vez mais inócuo. Em outras palavras, o valor da esterilização se torna expressivo apenas a partir da seção de aquecimento (2), sendo que o leite leva por volta de 13,5 segundos para chegar nesta seção. Na saída da seção de aquecimento (21 s), ocorreu redução decimal de, aproximadamente, $S V=1$ na concentração de micro-organismos.

Nas seções de regeneração e resfriamento (6 e 7), praticamente, não ocorreu queda na concentração microbiana, pois a temperatura do produto estava baixa devido à troca de calor com água fria. Contudo, o $S V$ é máximo nesta seção do equipamento, pois ele representa o acúmulo do efeito térmico de todas as outras seções e tubos do pasteurizador ao longo do tratamento térmico. 
Houve variação na temperatura do leite (queda de $4,4^{\circ} \mathrm{C}$ ) desde a entrada no tubo 1 (3) até a entrada da regeneração (5) devido à perda de calor para o ambiente. Essa perda de calor para o ambiente é indesejável porque resulta em perda de eficiência energética do processo, pois a energia que seria usada para tratar termicamente o produto é transferida ao ambiente. Uma das maneiras de se reduzir esse problema é através do uso de materiais com melhor capacidade de isolamento térmico e computando esse efeito durante o projeto de um pasteurizador.

O tubo de retenção é dimensionado para garantir que o produto fique na temperatura e no tempo correto do binômio determinado para a sua pasteurização. Nesse sentido, caso o leite seja subprocessado na retenção, ele será retornado à alimentação do processo pela atuação da válvula diversora de fluxo. A fim de evitar esse reprocessamento bem como o sobreprocessamento do produto, o efetivo dimensionamento e controle do processo são fundamentais (IBARROLA et al., 2002).

Embora a maior parte da inativação da $C$. burnetti ocorra no tubo de retenção e em suas conexões, pela Figura 6.6, percebe-se que ela também ocorre na seção de aquecimento do pasteurizador (2).

Jung e Fryer (1999) realizaram a simulação da esterilização de um alimento líquido viscoso não-newtoniano e fluido newtoniano em trocador de calor tubular, considerando uma modelagem fenomenológica para a letalidade microbiana e a perda de qualidade do nutriente tiamina devido ao tratamento térmico. Os resultados mostraram que a inativação térmica microbiana também ocorre na seção de aquecimento, e não só no tubo de retenção, e que a destruição do nutriente também ocorre em ambas as partes do equipamento. Com isso, o produto final acaba sendo sobre-processado.

Nesse contexto, pela Figura 6.6, considerando apenas a letalidade no tubo de retenção (4), obteve-se $S V=10$. Contudo, considerando o tubo de retenção e suas conexões $(3,4$ e 5$)$, a letalidade $(S V)$ foi equivalente a 20 , ou seja, o dobro. Essa redução microbiana é registrada pelo fato das conexões do tubo de retenção aumentarem a residência do produto em alta temperatura, o que causa sobreprocessamento do mesmo. Isto é, as taxas máximas de destruição microbiana são observadas no tubo de retenção e em suas duas conexões (3, 4 e 5), pois o leite está na maior temperatura (até $74,1^{\circ} \mathrm{C}$ ) e por, aproximadamente, 30 segundos. Nesse sentido, a inclinação da curva de letalidade é máxima na seção 3 (conexão 1), a qual fica entre e saída da seção de aquecimento e a entrada da retenção, o que representa 
a maior taxa de destruição térmica. Esse efeito térmico deve ser levado em conta durante o dimensionamento e o controle do projeto de pasteurizadores a fim de evitar o sobreprocessamento do produto, o que causa perda de qualidade. Ao mesmo tempo, é de suma importância atender aos requisitos mínimos da pasteurização - o binômio de tempo e temperatura - estabelecidos pela legislação brasileira, a qual estabelece temperatura de tratamento entre 72 a $75^{\circ} \mathrm{C}$ durante de 15 a $20 \mathrm{~s}$, em pasteurizador a placas dotado de painel de controle com termo-registrador e termoregulador automáticos, sensor de temperatura e válvula automática de desvio de fluxo. Contudo, a instrução normativa permite tratamentos equivalentes (BRASIL, 2002).

Sobre o tubo de retenção, a temperatura média foi igual a $73,3^{\circ} \mathrm{C}$ e a letalidade $(S V)$ foi igual a 10, mas, considerando as conexões 1 e 2, a letalidade ( $S V$ ) foi para 20, como já comentado anteriormente. A temperatura de entrada do leite no tubo de retenção foi igual a $73,9{ }^{\circ} \mathrm{C}$ e a de saída $72,7^{\circ} \mathrm{C}$, sendo essa variação ocasionada devido à perda de calor durante a sua passagem pelo tubo.

De acordo com Cerf e Condron (2006), para o micro-organismo C. burnetii, a pasteurização a $72{ }^{\circ} \mathrm{C}$ por 15 segundos (no tubo de retenção), deverá causar uma redução decimal de 8 ciclos logarítmicos.

Gut et al. (2004), em um estudo da modelagem e simulação do processo HTST da pasteurização de leite bovino, avaliaram os valores da temperatura do produto e da letalidade ao longo do tempo espacial em estado estacionário. Os autores obtiveram históricos similares aos da Figura 6.6 e concluíram que mais de 75 \% da inativação celular da $C$. burnetti ocorre no tubo de retenção seguido da seção de aquecimento com $19 \%$ de contribuição.

Aguiar e Gut (2014), realizaram um estudo similar ao de Gut et al. (2004), porém, levaram em conta o efeito da letalidade da inativação térmica da bactéria $C$. burnetti. Além disso, os autores validaram os perfis de temperatura e da letalidade em quatro temperaturas diferentes $\left(70,75,80\right.$ e $\left.85^{\circ} \mathrm{C}\right)$, com base na enzima fosfatase alcalina, utilizando água como fluido de estudo. Os resultados encontrados dos históricos teóricos e experimentais apresentaram boa concordância e o perfil de temperatura obtido pelos autores para o caso estacionário está similar aos da Figura 6.6. Eles consideram que o processamento ideal para este caso seria em altas temperaturas e, como consequência, inativação térmica do indicador-alvo apenas na retenção.

A Figura 6.7 mostra a distribuição de temperatura do leite em estado estacionário, em relação ao espaço discretizado e adimensionalizado $(\eta)$, ao longo 
dos canais do PHE, especificamente na seção de aquecimento. Também, na mesma figura, tem-se a concentração microbiana média (UFC/mL) na mesma seção do equipamento, só que apenas nos canais ímpares, os que contêm produto.

Segundo a Figura 6.7, o leite entra parcialmente aquecido no primeiro canal da seção de aquecimento devido ao seu pré-aquecimento na regeneração do pasteurizador (Figura 6.6). Após isso, ele vai recebendo calor durante o escoamento pelos canais do PHE, oriundo da utilidade de aquecimento, fazendo com que a sua temperatura vá aumentando ao longo do processo. Ao mesmo tempo, a concentração celular média de $C$. burnetti vai decaindo à medida que a temperatura do produto aumenta, sendo isso já esperado. Contudo, a concentração só começa a decair de modo expressivo a partir do canal 9 , para a temperatura média de $68,2^{\circ} \mathrm{C}$. Em suma, a temperatura média do leite foi de $43^{\circ} \mathrm{C}$ e sua concentração microbiana foi de $1,0 \mathrm{x}$ $10^{5} \mathrm{UFC} / \mathrm{mL}$ no canal 1 até $75^{\circ} \mathrm{C}$ e $4,01 \times 10^{4} \mathrm{UFC} / \mathrm{mL}$, no canal 11 .

Figura 6.7 - Distribuição de temperatura (curvas) e da concentração média de $C$. burnetti nos canais ímpares (pontos) da seção de aquecimento na simulação da pasteurização em estado estacionário.

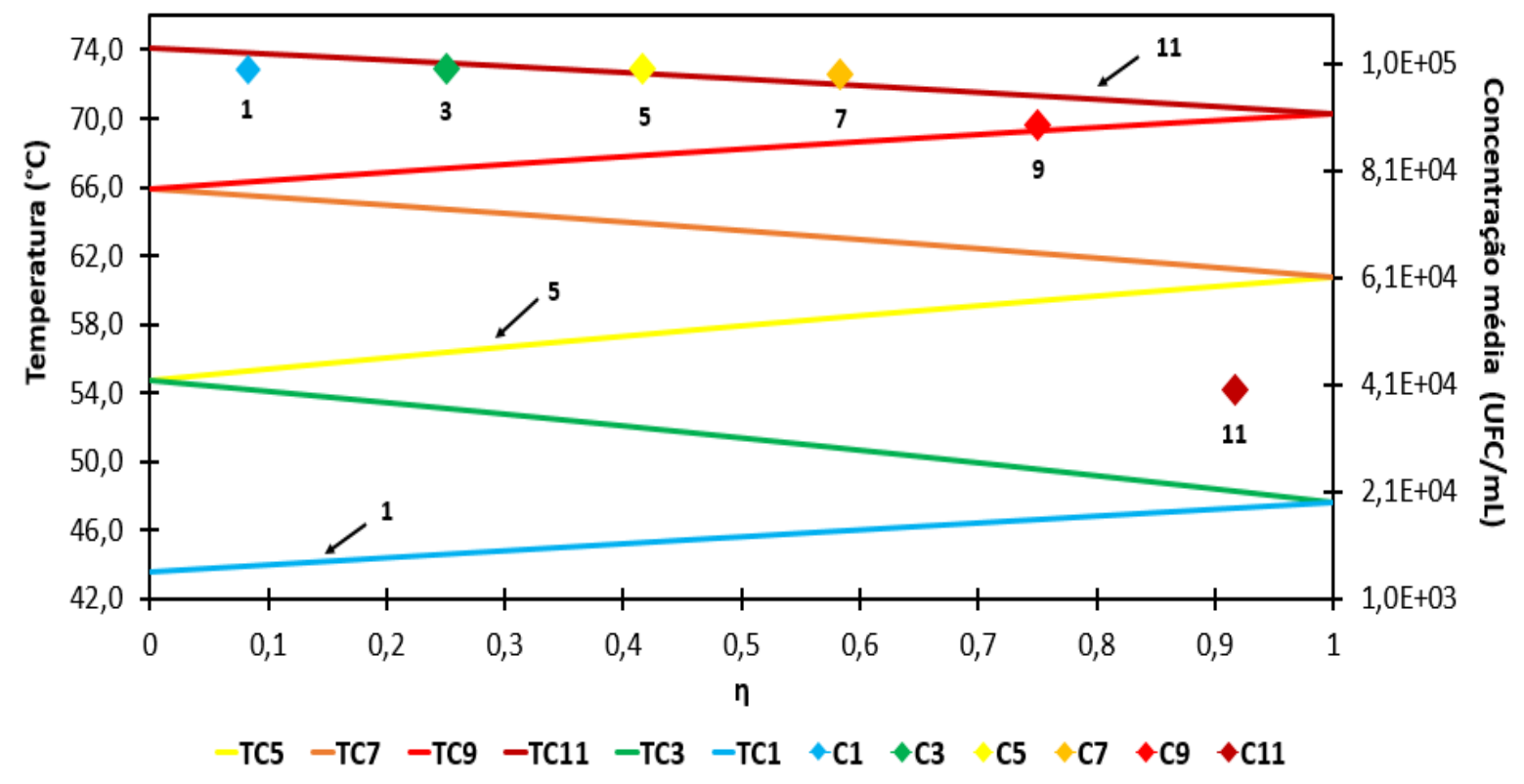

Benze (2013) simulou um modelo fenomenológico baseado em transferência de calor unidimensional e em letalidade para os micro-organismos $C$. burnetii, Salmonella spp. e E. coli, também em pasteurizador a placas e para leite bovino. Foram comparados dois cenários: tempo médio de residência e o tempo espacial. Contudo, 
não foram computadas as variações temporais, sendo, então, o processo unicamente estacionário, e sem levar em conta a incrustação do produto. Foi realizada a validação dos perfis de temperatura do produto, tempo médio de residência e espacial e, para validação da letalidade, foi utilizado indicador enzimático de fosfatase alcalina. Os resultados laboratoriais e teóricos apresentaram-se satisfatoriamente similares.

A temperatura das placas, ao longo do espaço discretizado, e a temperatura média por placa, na seção de aquecimento do trocador de calor, é mostrada nas Figuras 6.8 e 6.9 .

Figura 6.8 - Distribuição de temperatura ao longo do espaço adimensionalizado em todas as placas da seção de aquecimento na simulação em estado estacionário.

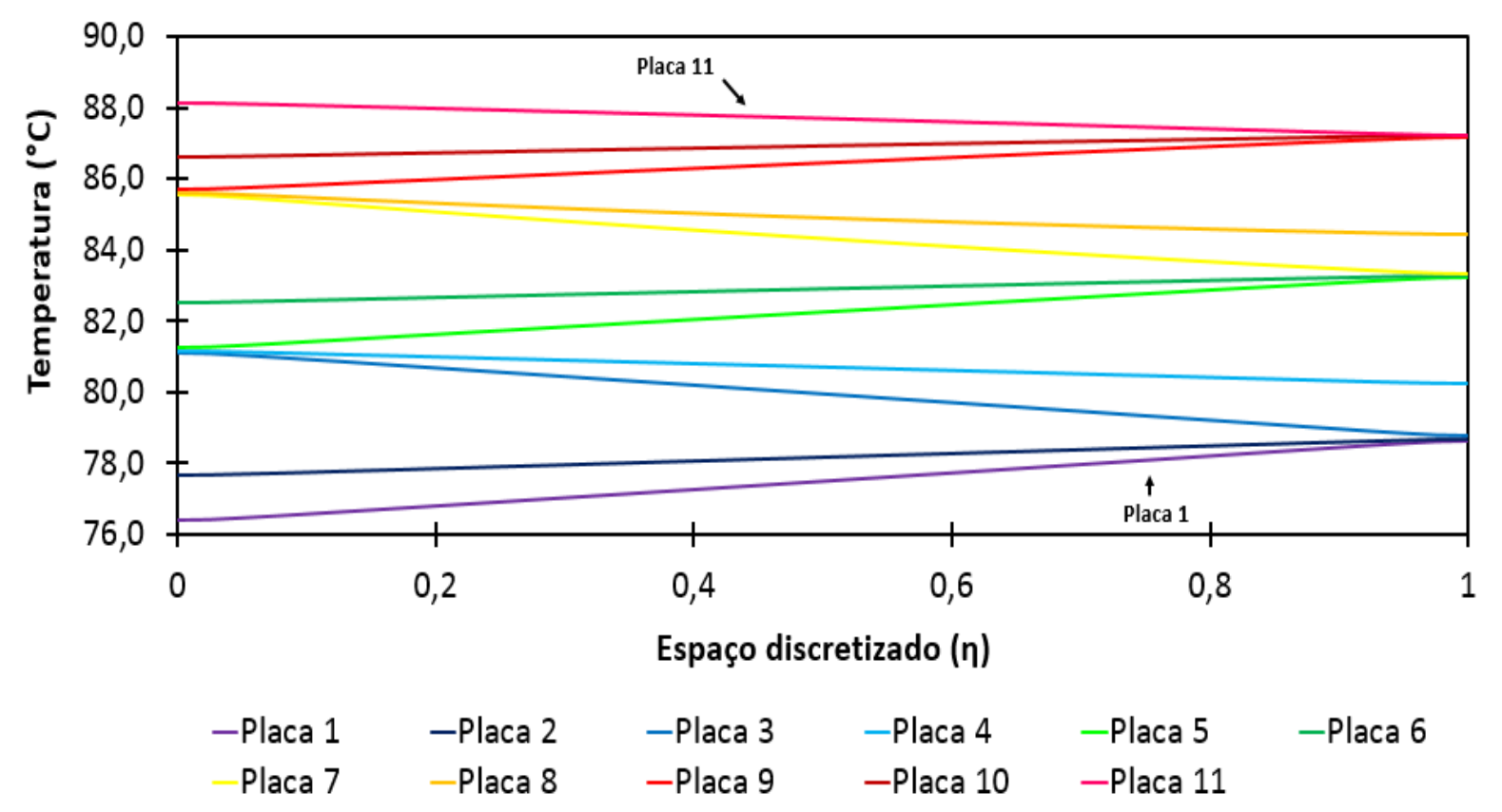

Pela Figura 6.8, percebe-se que a temperatura média das 11 placas é crescente, ou seja, a temperatura aumenta desde a placa $1\left(75,7^{\circ} \mathrm{C}\right)$ até a placa $11\left(85,9^{\circ} \mathrm{C}\right)$, como reforçado pela Figura 6.9. Esse comportamento ocorre devido a dois fatores que se somam, que são: a) o leite frio $\left(43,6^{\circ} \mathrm{C}\right)$ entra no canal 1 (placa 1 ) e sai aquecido $\left(74,1^{\circ} \mathrm{C}\right.$ ) no canal 11 (placa 11 ), como já mostrado na Figura $\left.6.7 ; \mathrm{b}\right)$ a utilidade de aquecimento que entra a alta temperatura $\left(90^{\circ} \mathrm{C}\right.$ ) no canal 10 (placa 10) e sai do trocador de calor a uma menor temperatura $\left(80,6^{\circ} \mathrm{C}\right)$ pelo canal 2 . 
Figura 6.9 - Distribuição de temperatura média em todas as placas da seção de aquecimento na simulação da pasteurização em estado estacionário.

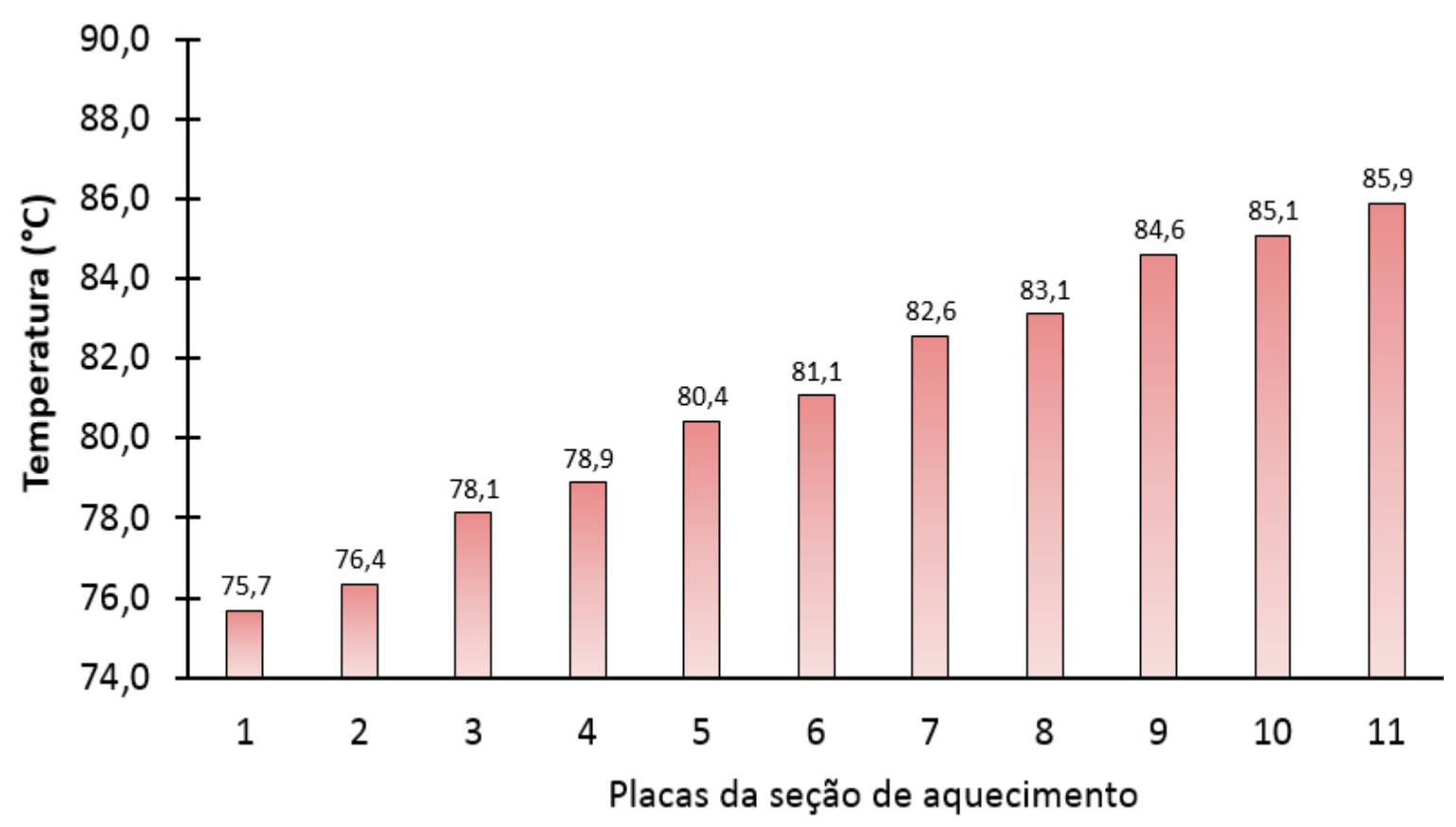

Georgiadis e Macchietto (2000), em um estudo do processamento de leite bovino em PHE sujeito à incrustação, por modelagem fenomenológica, também em gPROMS, obtiveram padrões de temperatura similares aos da Figura 6.8.

É perceptível o padrão de aumento da temperatura das placas ao longo do espaço discretizado, no sentido positivo, apenas paras as placas 1, 2, 5, 6 e 9 e 10 . De modo contrário, há o padrão de diminuição da temperatura das placas ao longo do espaço discretizado, no sentido positivo, mas, apenas, para as 3, 4, 7 e 8, mesmo que a temperatura média das placas aumente ao longo do escoamento do leite. A explicação para isso está no fato de os fluidos - utilidade e leite -, que escoam por entre os canais do PHE, fazerem caminhos ascendentes e descendentes, e alterando o sentido do escoamento na direção vertical, como exemplificado para um caso específico na Figura 4.7.

Nas Tabelas 6.1 e 6.2 são mostrados os intervalos dos valores calculados para os adimensionais, Reynolds $(R e)$, Nusselt $(N u)$ e Prandtl $(P r)$, para os coeficientes de transferência de calor local $(h)$ e global $(U)$, e alguns dos parâmetros termofísicos $(C p, k, \mu)$, para o leite e para a utilidade de aquecimento, ao longo dos canais dos trocadores de calor do pasteurizador, na simulação do estado estacionário. 
Tabela 6.1 - Intervalos calculados para algumas das variáveis e parâmetros da modelagem para o leite bovino na vazão nominal, em estado estacionário, nos PHEs.

\begin{tabular}{ccc}
\hline Parâmetro & Intervalo & Unidade \\
\hline$R e$ & $175,8-81,6$ & - \\
$P r$ & $10,03-20,92$ & - \\
$N u$ & $5,02-3,29$ & - \\
$h_{i}$ & $629,0-412,5$ & $\mathrm{~W} / \mathrm{m}^{2} . \mathrm{K}$ \\
$U_{i}$ & $615,4-406,2$ & $\mathrm{~W} / \mathrm{m}^{2} . \mathrm{K}$ \\
$k$ & $0,37-0,38$ & $\mathrm{~W} / \mathrm{K} \cdot \mathrm{m}$ \\
$C p$ & 3460 & $\mathrm{~J} / \mathrm{kg} . \mathrm{K}$ \\
$\mu$ & $1,09 \times 10^{-3}-2,44 \times 10^{-3}$ & Pa.s \\
\hline
\end{tabular}

Tabela 6.2 - Intervalos calculados para algumas das variáveis e parâmetros da modelagem para a utilidade quente na vazão nominal, em estado estacionário, nos PHEs.

\begin{tabular}{ccc}
\hline Parâmetro & Intervalo & Unidade \\
\hline$R e$ & $365,8-1785,1$ & - \\
$P r$ & $11,07-1,86$ & - \\
$N u$ & $9,78-21,33$ & - \\
$h_{i}$ & $1885-4821$ & $\mathrm{~W} / \mathrm{m}^{2} . \mathrm{K}$ \\
$U_{i}$ & $1761-4086$ & $\mathrm{~W} / \mathrm{m}^{2} . \mathrm{K}$ \\
$k$ & $0,58-0,68$ & $\mathrm{~W} / \mathrm{K} . \mathrm{m}$ \\
$C p$ & $4215-4213$ & $\mathrm{~J} / \mathrm{kg} . \mathrm{K}$ \\
$\mu$ & $2,99 \times 10^{-4}-1,52 \times 10^{-3}$ & $\mathrm{~Pa} . \mathrm{S}$ \\
\hline
\end{tabular}

Os resultados encontrados para algumas destas propriedades termofísicas do leite, como calor específico, densidade, viscosidade e condutividade térmica, estão de acordo com a literatura (SHERBON, 1988; SINGH et al., 1997; WALSTRA, JENNESS, 1984). 
Em relação à água e ao leite, pelas Tabela 6.1 e 6.2, percebeu-se o quanto a temperatura afeta os parâmetros calculados para este problema. Baseado nisso, enfatiza-se que os parâmetros de engenharia do sistema bem como propriedades termofísicas dos fluidos, e variáveis de interesse do problema, devam ser calculados criteriosamente, evitando erros durante o dimensionamento e modelagem do equipamento, os quais repercutirão nos dados simulados.

Como a velocidade média do leite ao longo dos canais dos PHEs, na vazão nominal de $20 \mathrm{~L} / \mathrm{h}$, é de $0,062 \mathrm{~m} / \mathrm{s}$ e, como o número de Reynolds é igual a 125,6 (na temperatura de $55^{\circ} \mathrm{C}$ ), pode-se dizer que o escoamento apresentou baixos valores de $R e$.

Nesse mesmo PHE foi realizado um estudo para entender o comportamento do escoamento de uma solução salina, baseado na distribuição do tempo de residência através de uso de modelos combinados não-ideais (GUTIERREZ et al., 2011).

Nesse escopo, Galeazzo et al. (2006) realizaram um estudo com foco em efeitos hidrodinâmicos, em um PHE com 4 canais, através da comparação de dados experimentais e teóricos, avaliando a transferência de calor para o escoamento unidimensional plug flow e tridimensional pelo uso da técnica de CFD. A simulação foi realizada considerando modelo de escoamento laminar e turbulento. Os autores afirmam que o escoamento estaria mais próximo do regime laminar, mas também apresenta regiões de turbulência, especialmente nos orifícios das placas. Eles avaliaram o processo numa vazão entre 0,3 e 0,8 L/min e obtiveram velocidades entre 0,06 e $0,12 \mathrm{~m} / \mathrm{s}$ para o modelo unidimensional.

Geralmente, em PHEs, a transição do regime de escoamento laminar para turbulento é entre $R e=400$ e $R e=500$, embora isso dependa das corrugações das placas do trocador de calor. Além disso, quanto maior for o valor do número de Reynolds nas placas do PHE, maior será a velocidade do fluido, principalmente em seus orifícios (JIN et al., 2008).

Já no tubo de retenção, coincidentemente, a velocidade média do leite também é igual a 0,062 m/s e o número de Reynolds equivalente a 391,9, na temperatura de $73^{\circ} \mathrm{C}$ e na vazão nominal. Analisando apenas o valor de $R e$, para tubos circulares (este caso), é possível avaliar a consideração de escoamento laminar (BIRD et al., 2002). Contudo, embora os valores de número de Reynolds no pasteurizador tenham sido baixos, a hipótese de escoamento pistonado permanece mantida, pois, caso fosse considerado escoamento laminar, a modelagem matemática seria altamente 
complexa devido à variação da velocidade e tempo de residência do produto na seção do canal.

Ndoye et al. (2012), em um estudo sobre a influência da agregação de proteínas do soro de leite na distribuição do tempo de residência em um pasteurizador tubular, durante o tratamento térmico de uma solução simulada ao leite bovino, obtiveram resultados similares aos deste trabalho. Na vazão de $20 \mathrm{~L} / \mathrm{h}$, os autores encontraram valores de $R e=995$ e $R e=1265$, para o escoamento da solução, no trocador de calor tubular e no tubo de retenção helicoidal, respectivamente, caracterizando o regimento laminar nos tubos e na retenção do trocador. Também foi avaliado o mesmo processo na vazão de $49 \mathrm{~L} / \mathrm{h}$, obtendo valores de $R e=2701$ e $R e=3110$, para o escoamento da solução, no trocador de calor tubular e no tubo de retenção, respectivamente, indicando regimento de transição entre laminar e turbulento.

Em um trabalho similar, Belmar-Beiny et al. (1993), a fim de avaliar a influência do número de Reynolds num processo de pasteurização de fluido simulado ao leite bovino, obtiveram valores deste adimensional entre 1800 e 9000, durante o ensaio de 1 hora, com temperatura de entrada e saída do produto iguais a $73^{\circ} \mathrm{C}$ e $83{ }^{\circ} \mathrm{C}$, respectivamente. A investigação do efeito da influência da incrustação devido à variação do número de Reynolds, em um trocador de calor tubular, mostrou que para Re maior, menor será a formação de depósitos.

Com o intuito de avaliar o quanto a vazão da utilidade de aquecimento afeta a pasteurização em estado estacionário, fez-se a comparação deste processo para quatro tratamentos diferentes. Nesse contexto, as Figuras 6.10 e 6.11 representam esses casos, para todas as seções e tubos do equipamento, ao longo do tempo espacial. As curvas foram obtidas nas vazões de 30, 60 (vazão nominal), 90 e $120 \mathrm{~L} / \mathrm{h}$ de água de aquecimento. Mais uma vez, as indicações 1, 2, 3, 4, 5, 6 e 7, correspondem às seções de regeneração, aquecimento, conexão 1, tubo de retenção, conexão 2, regeneração e resfriamento, respectivamente.

Obviamente que os perfis de temperatura para estas simulações são bastante similares à Figura 6.6. A maior e mais importante diferença está no histórico de temperatura do leite nas seções de aquecimento e retenção, a qual é a principalmente, mas não única, responsável pela destruição de micro-organismos do produto. 
Figura 6.10 - Distribuição de temperatura do leite em relação ao tempo espacial, em quatro diferentes vazões da utilidade de aquecimento, durante a pasteurização.

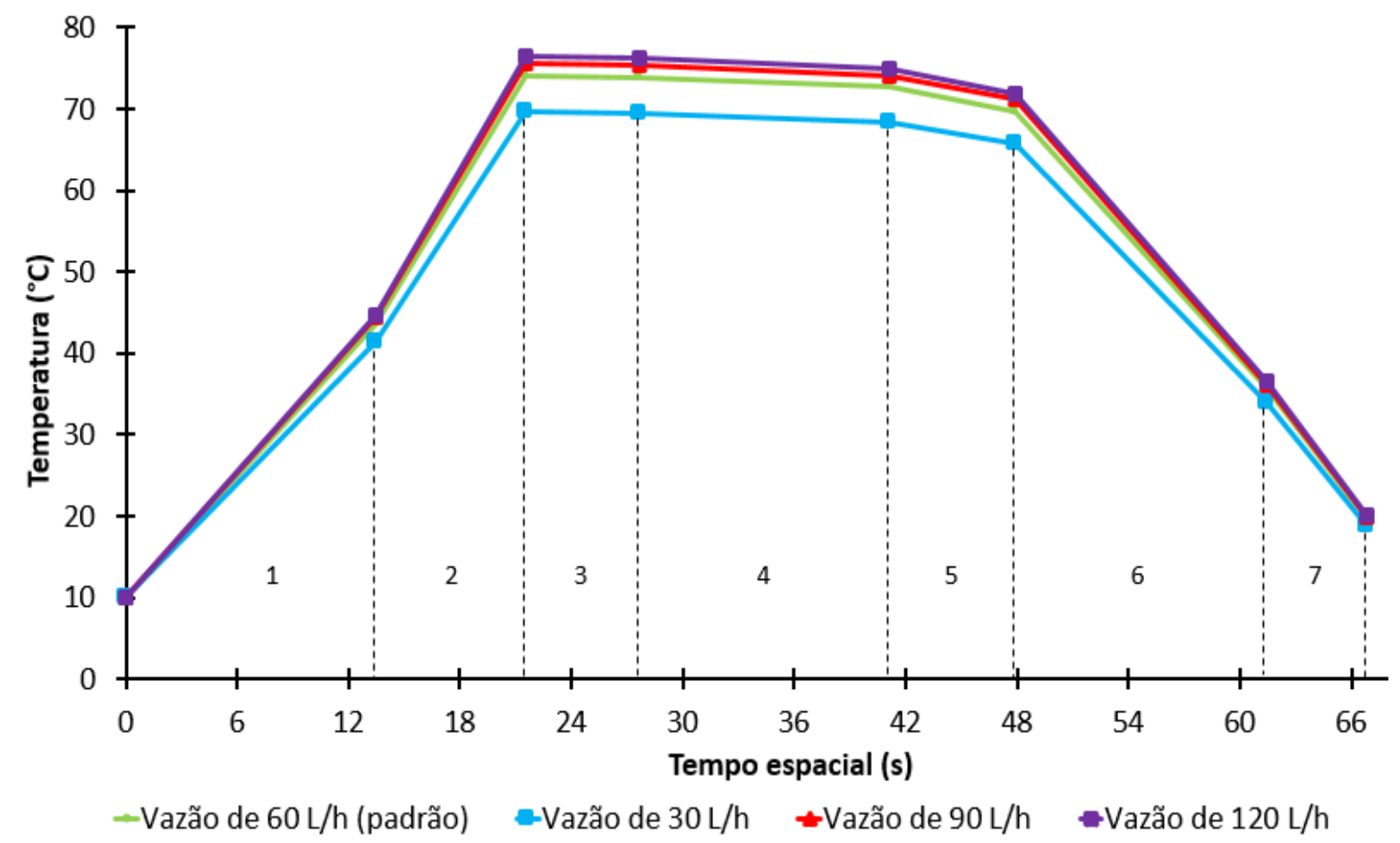

Figura 6.11 - Distribuições da letalidade simulada em relação ao tempo espacial, em quatro diferentes vazões da utilidade de aquecimento, durante a pasteurização.

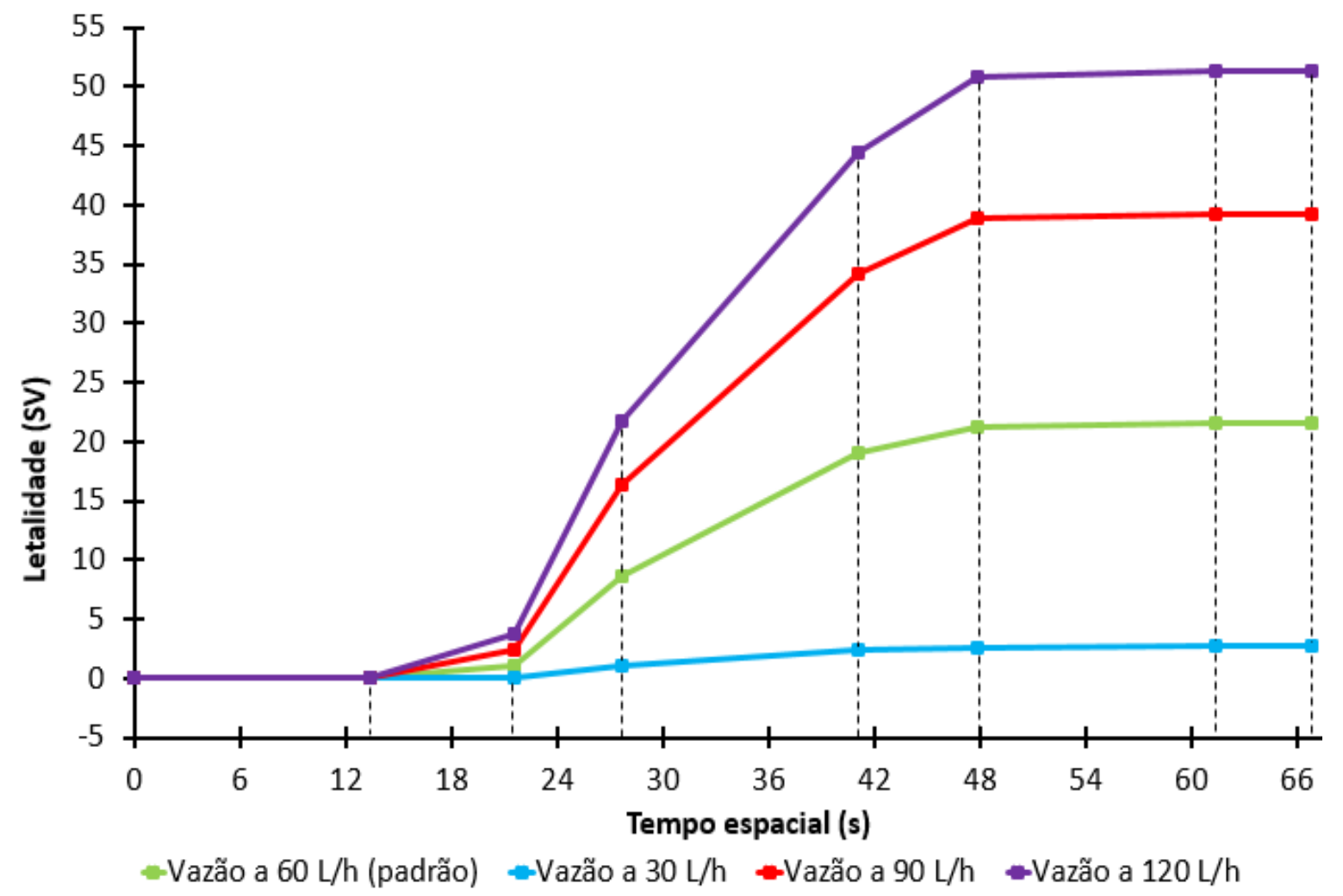


Esses resultados indicam que, quanto maior a vazão da água de aquecimento, maior será a taxa de transferência de calor para o leite, resultando em temperaturas mais elevadas, e, consequentemente, levando a uma maior destruição microbiana e letalidade. Por exemplo, na vazão de $60 \mathrm{~L} / \mathrm{h}$ (nominal), o valor final para esterilização $(S V)$ foi igual a 21, enquanto que para uma vazão de $120 \mathrm{~L} / \mathrm{h}$ foi equivalente a 51.

Além disso, em uma análise visual, percebe-se que a sensibilidade do processo a diferentes vazões é maior para letalidade (Figura 6.11) quando se comparado com a temperatura do leite (Figura 6.10). Isto é, uma pequena variação na temperatura do produto durante a sua pasteurização, já é suficiente para provocar grandes variações na destruição dos micro-organismos, representada pela letalidade. Por exemplo, entre a seção 5 e 6, no tempo espacial de 48 segundos, quando se opera na vazão de 30 $\mathrm{L} / \mathrm{h}$, tem-se uma temperatura de $65,7^{\circ} \mathrm{C}$ e letalidade $(S V)$ de 3. Já na vazão de $60 \mathrm{~L} / \mathrm{h}$, tem-se uma temperatura de $69,7{ }^{\circ} \mathrm{C}$ e letalidade $(S V)$ de 21 , comparando com o mesmo ponto. Logo, uma variação de $4,0^{\circ} \mathrm{C}$ e $S V=18$. Baseado nisso, fica claro que não só a temperatura afeta o grau de esterilidade comercial do leite, mas também a vazão da utilidade de aquecimento.

O entendimento do processo e das perturbações de suas variáveis, nesse caso, temperatura e vazão é importante a fim de controlar e predizer o comportamento da pasteurização. Deste modo, é possível evitar o sobre e/ou subprocessamento do produto, operando na idealidade.

Nesse contexto, segundo Mokhtar et al. (2012), através da modelagem dinâmica do processo de pasteurização, é possível não só entender profundamente estas questões, como controlar e manipular o processo de modo assertivo.

\subsection{Perturbações no Processo}

A seguir são mostrados os resultados obtidos para diferentes simulações, quando o processo sofreu perturbações em algumas de suas variáveis, sendo elas: concentração inicial de micro-organismos no leite cru, temperatura inicial do leite cru e vazão e temperatura de entrada da utilidade de aquecimento. 


\subsubsection{Concentração Inicial de Micro-organismos}

As condições operacionais consideradas na simulação deste cenário foram mostradas na Tabela 5.11 da Seção 5.5.

Pela Figura 6.12, tem-se a distribuição dos perfis de concentração microbiana para o tratamento térmico simulado, ao longo do tempo de processo, para cada uma das perturbações as quais o sistema foi sujeitado. As indicações C1, C2, C3, C4, C5 e C8, correspondem à concentração de micro-organismos na entrada do equipamento, no início da seção de aquecimento, e assim por diante, como já explicado anteriormente. Já as indicações A, B, C, D e E, representam os seguintes cenários: processo sem perturbação (concentração inicial igual a $1 \times 10^{5} \mathrm{UFC} / \mathrm{mL}$ ); perturbação 1 (concentração inicial igual a $1 \times 10^{8} \mathrm{UFC} / \mathrm{mL}$ ), retomada da condição inicial, perturbação 2 (concentração inicial igual a $1 \times 10^{2} \mathrm{UFC} / \mathrm{mL}$ ) e retomada da condição inicial novamente, respectivamente.

Figura 6.12 - Distribuição do Log da concentração microbiana ao longo do tempo quando o sistema sofreu perturbações na concentração inicial de $C$. burnetii no leite.

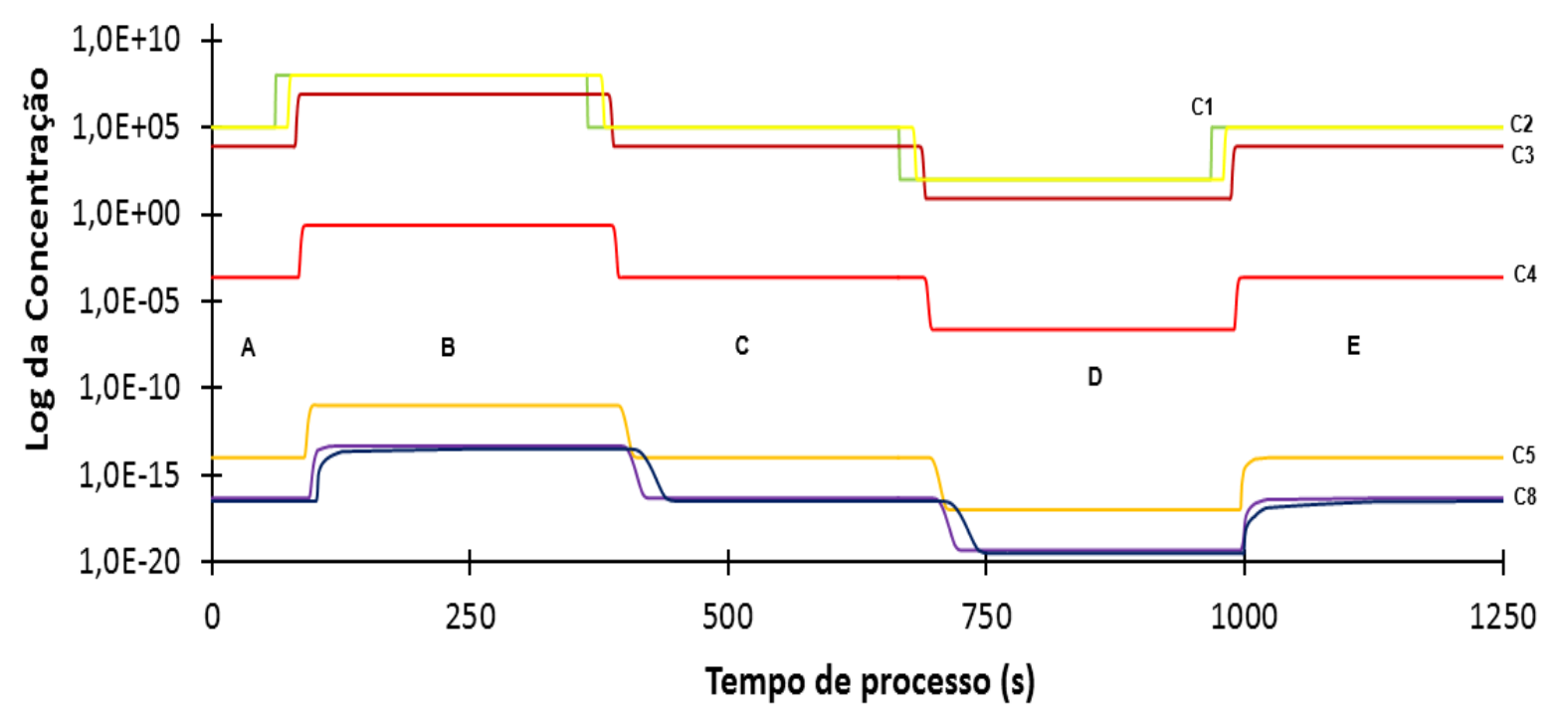

Observa-se que o aumento, ou a diminuição, na concentração inicial de $C$. burnetii ( $\mathrm{C} 1$ ) afeta os perfis de concentração microbiana em todas as seções do pasteurizador (C2, C3, C4, C5 e C8) ao longo do tempo de processo.

Comparando os perfis $\mathrm{C} 1$ até $\mathrm{C} 8$, percebe-se que há certo atraso no valor da concentração bacteriana quando o sistema foi perturbado, tanto para um aumento na 
concentração de micro-organismos $(A \rightarrow B)$ quando para uma diminuição $(C \rightarrow D)$. Este atraso representa o tempo que o leite leva para escoar de uma seção a outra.

A Figura 6.13, apresenta três curvas de decaimento logarítmico na concentração de $C$. burnetii ao longo do tempo espacial, da pasteurização no estado transiente, em três tempos de processo $(60,360$ e $960 \mathrm{~s})$, oriundos da simulação na Figura 6.12, sendo uma para concentração microbiana inicial padrão, igual a $1 \times 10^{5} \mathrm{UFC} / \mathrm{mL}$ (valor original das simulações), outra inicial igual a $1 \times 10^{8} \mathrm{UFC} / \mathrm{mL}$ (perturbação 1) e a última para $1 \times 10^{2}$ UFC/mL (perturbação 2).

Percebe-se que o decaimento logarítmico decimal total foi o mesmo nos três casos, mas a concentração final foi diferente. Este resultado ilustra que, embora a letalidade devido ao tratamento térmico possa ser a mesma, a concentração final de bactérias não será. Então, caso o leite a pasteurizar seja de baixa qualidade microbiológica (maior contagem de bactérias, por exemplo), o tratamento térmico aplicado usualmente (predeterminado) poderá ser insuficiente para garantir a inocuidade do produto final, tendo, portanto, maior concentração de micro-organismos no mesmo. Por outro lado, caso o leite recebido seja de melhor qualidade microbiológica (menos contagem de bactérias, por exemplo), poderá ocorrer o inverso. Por isso é de suma importância que o processo seja controlado corretamente e que a matéria-prima seja sempre padronizada.

Figura 6.13 - Distribuição do Log da concentração microbiana ao longo do tempo espacial para três concentrações iniciais de $C$. burnetii no leite cru.

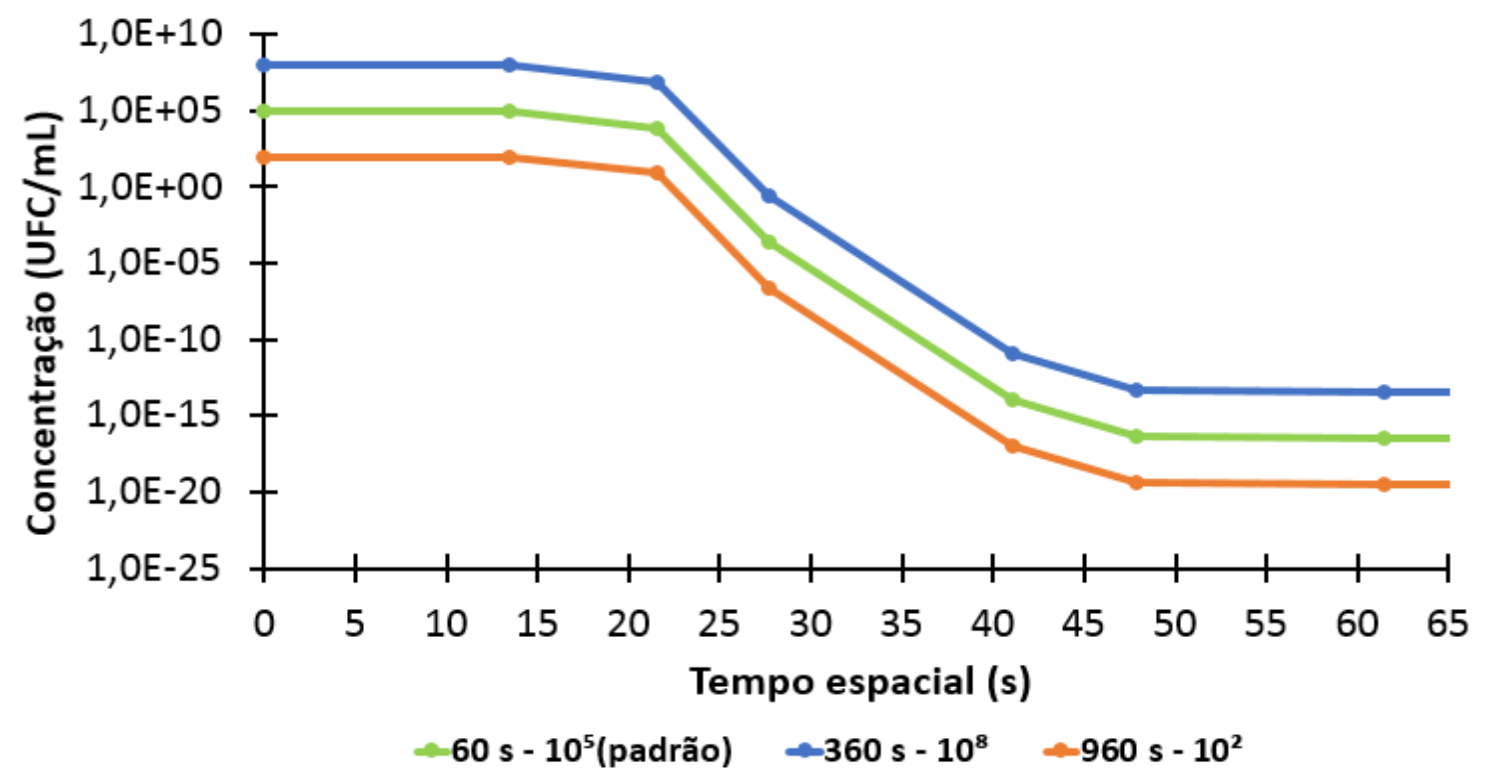


Nesse sentido, uma das formas de se garantir que o leite a se processar seja de boa qualidade microbiológica (baixa contaminação inicial) é o seu correto e asséptico manejo desde a sua captação até a sua industrialização, além da conservação pela cadeia do frio (BYLUND, 1995).

\subsubsection{Temperatura de Entrada da Água e do Leite Cru}

Os parâmetros operacionais usados para estes casos podem ser vistos nas Tabelas 5.9 (para água) e 5.10 (para leite) da Seção 5.5 .

As Figuras 6.14 e 6.18 mostram o comportamento dinâmico dos perfis de temperatura do leite e da letalidade ao tratamento térmico, ao longo do tempo de processo, quando ocorrem perturbações na temperatura da utilidade de aquecimento. Mais uma vez, as indicações T1, T2, T3, T4, T5, T6, T7 e T8, correspondem aos pontos de controle representativos do processo de pasteurização. De modo similar, as indicações L2, L3, L4, L5 e L8 fazem menção ao decaimento logarítmico decimal (letalidade), na entrada e na saída da seção de aquecimento, na entrada e na saída do tubo de retenção e na saída do resfriamento do leite, sendo estes pontos já mostrados e descritos na Figura 4.1 e no item 4.3.1, do capítulo de Modelagem.

Figura 6.14 - Histórico de temperatura do leite ao longo do tempo de processo da simulação das perturbações na temperatura de entrada da utilidade de aquecimento.

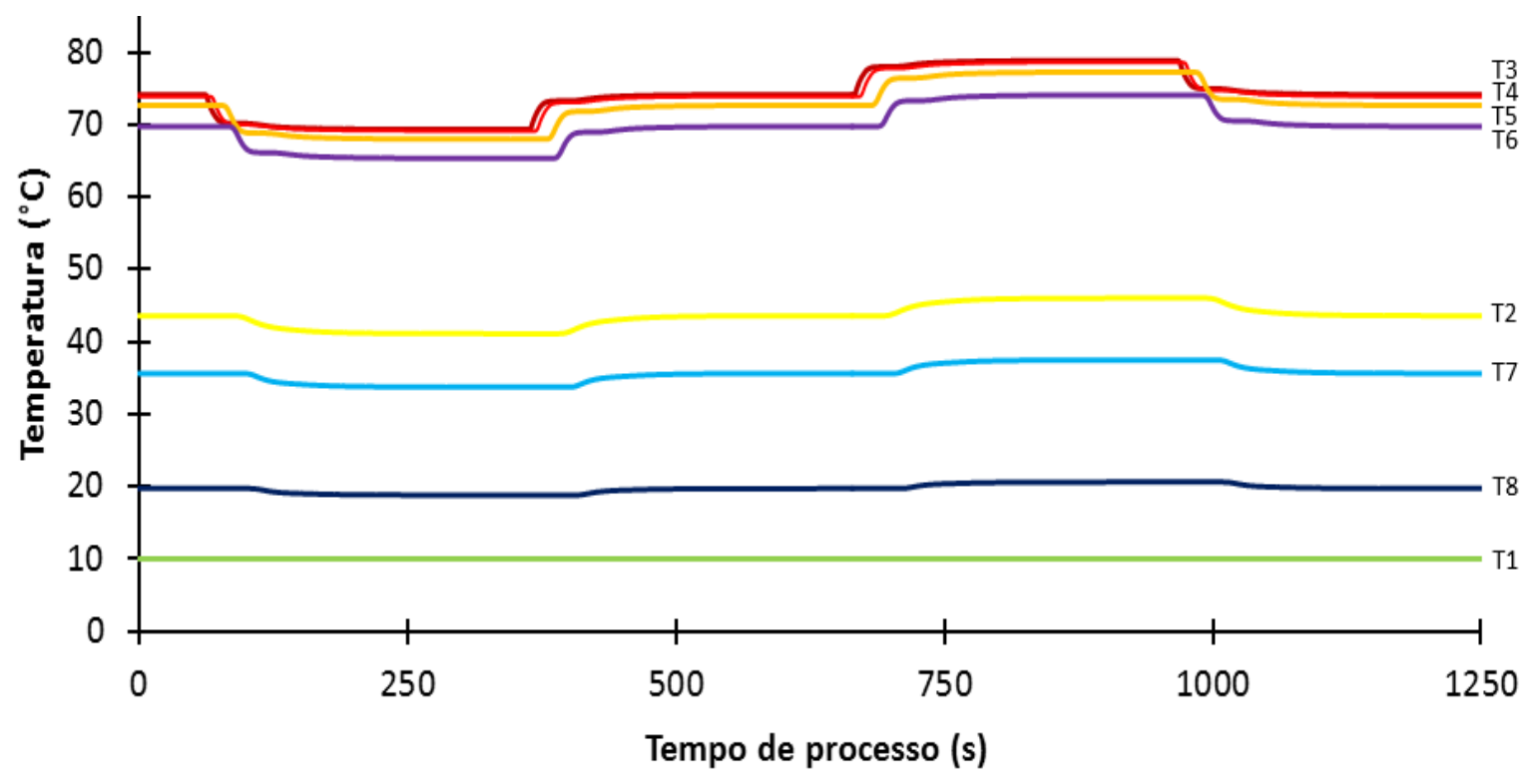


Inicialmente o processo foi simulado em sua condição normal, seguido de uma perturbação de diminuição do valor da temperatura de entrada da utilidade de aquecimento (Figura 6.14) ou na do leite (Figura 6.18). Na sequência, após o sistema ter sido restabelecido novamente, uma perturbação de diminuição da temperatura da utilidade de aquecimento (Figura 6.14) ou na do leite (Figura 6.18) foi causada no sistema, sendo que, após certo período de tempo, o processo foi restaurado.

Percebe-se que quando a temperatura da utilidade de aquecimento foi alterada, para o valor menor ( $t=60 \mathrm{~s}$ ) ou para maior $(t=660 \mathrm{~s}$ ), isso acarretou em variações consideráveis nos perfis de temperatura do leite, em todas as seções dos PHEs e nos tubos, exceto em T1, que é a entrada do produto cru no equipamento, o qual independe da temperatura da utilidade.

Variações são mais significativas na seção de aquecimento e nos tubos (T3, T4, T5 e T6) quando comparadas à seção fria do pasteurizador (T2, T7 e T8). Como visto para partida do pasteurizador, observa-se que cada vez que novo perfil de temperatura do leite era formado, sempre há formação do "degrau" oriundo da seção de regeneração, especialmente na seção de aquecimento e nos tubos do equipamento. A partir da Figura 6.14, isso pode ser observado mais detalhadamente pela Figura 6.15.

Figura 6.15 - Detalhamento dos degraus no histórico de temperatura do leite em T3, T4, T5 e T6 da simulação das perturbações na temperatura de água de aquecimento.

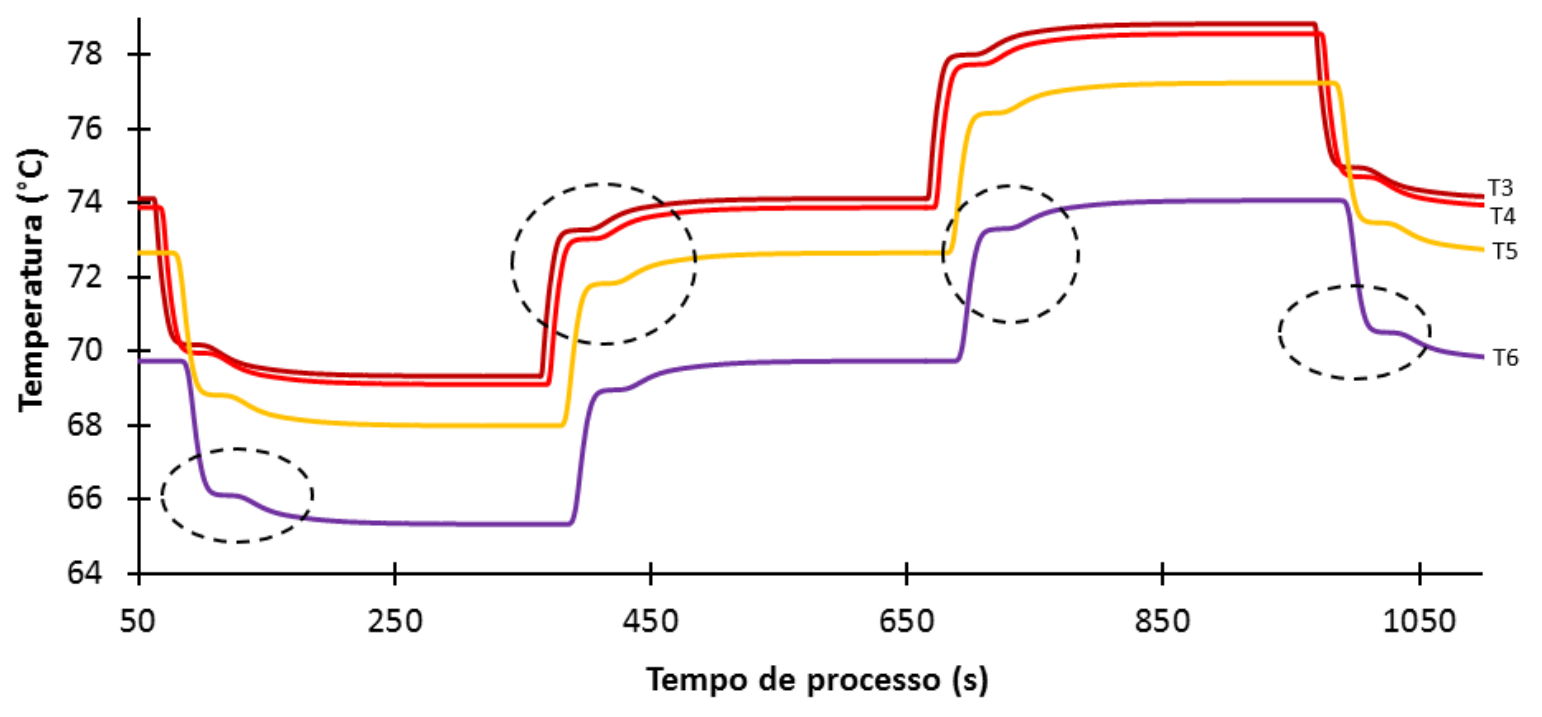

Os efeitos nos perfis de temperatura do leite, oriundos das variações na temperatura da utilidade de aquecimento, são refletidos no histórico de letalidade do 
tratamento térmico simulado, pois a concentração de micro-organismos depende da temperatura do produto, como já esperado (Figura 6.16).

Figura 6.16 - Distribuição da letalidade simulada ao longo do tempo da simulação das perturbações na temperatura de entrada da utilidade de aquecimento.

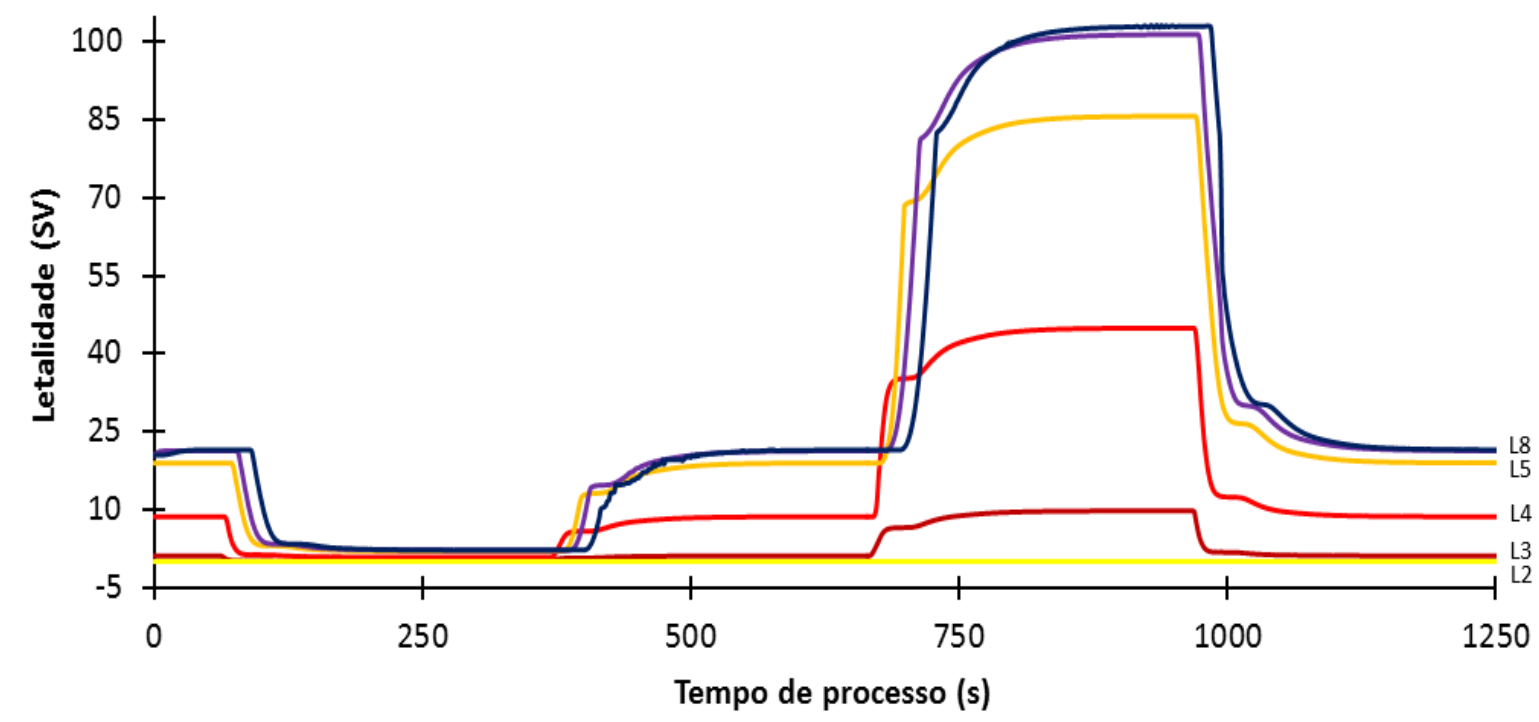

Quando o sistema sofreu a primeira perturbação na temperatura da utilidade de aquecimento, representada pela diminuição de sua temperatura de $90^{\circ} \mathrm{C}$ para $84^{\circ} \mathrm{C}$, no instante $t=60 \mathrm{~s}$, o tratamento se tornou pouco efetivo em relação à destruição bacteriana, já que o valor de $S V$ acumulado foi igual a 2 na saída do equipamento. Contrariamente, quando o sistema sofreu a segunda perturbação na temperatura da utilidade, referenciada pelo aumento de sua temperatura de $90{ }^{\circ} \mathrm{C}$ para $96{ }^{\circ} \mathrm{C}$, no instante $t=660 \mathrm{~s}$, o tratamento se tornou excessivo quanto à redução na concentração da microbiana, já que o valor de $S V$ acumulado foi igual a 101 (Figura 6.16).

Com estes resultados, enfatiza-se o quão importante é o correto e apurado controle do processo de pasteurização do leite, uma vez que uma simples modificação na temperatura da utilidade de aquecimento resultará em um produto com diferente grau de inocuidade.

A Figura 6.17, com base na Figura 6.16, mostra com mais profundidade os efeitos dos degraus formados nos perfis de temperatura do leite quando perturbações na temperatura de entrada da água quente eram impostos no sistema. 
Figura 6.17 - Detalhamento dos degraus da distribuição da letalidade em L6, L5, L4 e L3 da simulação das perturbações na temperatura de entrada da utilidade de aquecimento entre os instantes $t=50$ se $t=600 \mathrm{~s}$.

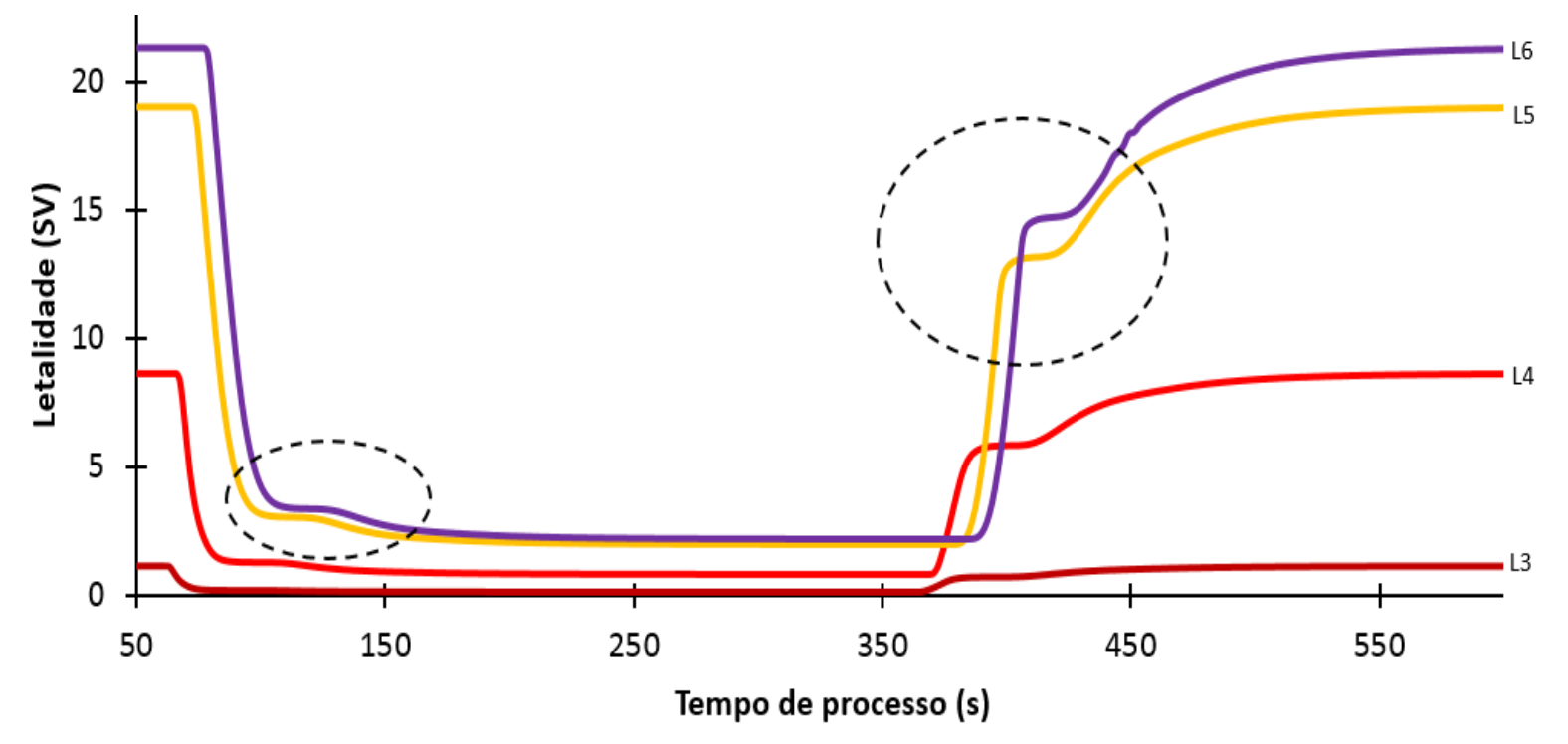

A partir da inspeção da Figura 6.17, é perceptível que uma pequena variação na temperatura do leite causa uma grande variação no valor da letalidade do tratamento, em vista da amplitude da variação dos valores de $S V$, bem como os mesmos degraus observados na Figura 6.15. Também fica nítido que a variação de $S V$ por volta do instante $t=400 \mathrm{~s}$ é mais pronunciada em relação à perturbação do instante $t=100$ s. A explicação para isto está nos diferentes valores de temperatura do leite, sendo, aproximadamente, iguais a $66^{\circ} \mathrm{C}$ em T6 e $69^{\circ} \mathrm{C}$ também em T6, respectivamente.

Similarmente ao caso anterior, as Figuras 6.18 e 6.19 representam os resultados obtidos quando o sistema sofreu perturbações (para mais e para menos) na temperatura de entrada do leite cru, no início da pasteurização (T1).

A Figura 6.18 ilustra que, cada vez que a temperatura inicial do leite cru sofreu alteração, obviamente, a temperatura do mesmo em todas as seções e nos tubos do pasteurizador também foi afetada, sendo esses efeitos mais pronunciados na regeneração. Isto é, essas variações são menos significativas na seção de aquecimento e nos tubos (T2, T3, T4, T5 e T6) quando comparadas à seção fria do pasteurizador (T7 e T8). Exemplificando, para a primeira perturbação de aumento na temperatura de entrada do leite cru, no instante $t=60 \mathrm{~s}$, observa-se uma variação de $35,6^{\circ} \mathrm{C}$ até $40,1^{\circ} \mathrm{C}(\mathrm{T} 7)$, ou seja, $\Delta T=4,5^{\circ} \mathrm{C}$. Já na saída do tubo de retenção (T5), essa variação foi bem menor, sendo de 72,7 até $73,9^{\circ} \mathrm{C}$, ou seja, $\Delta T=1,2^{\circ} \mathrm{C}$. Logo, 
percebe-se que amplitude da variação na temperatura, entre as seções, vai diminuindo à medida que se afasta do local da perturbação de origem.

Figura 6.18 - Histórico de temperatura do leite ao longo do tempo de processo da simulação da perturbação na temperatura de entrada do leite cru.

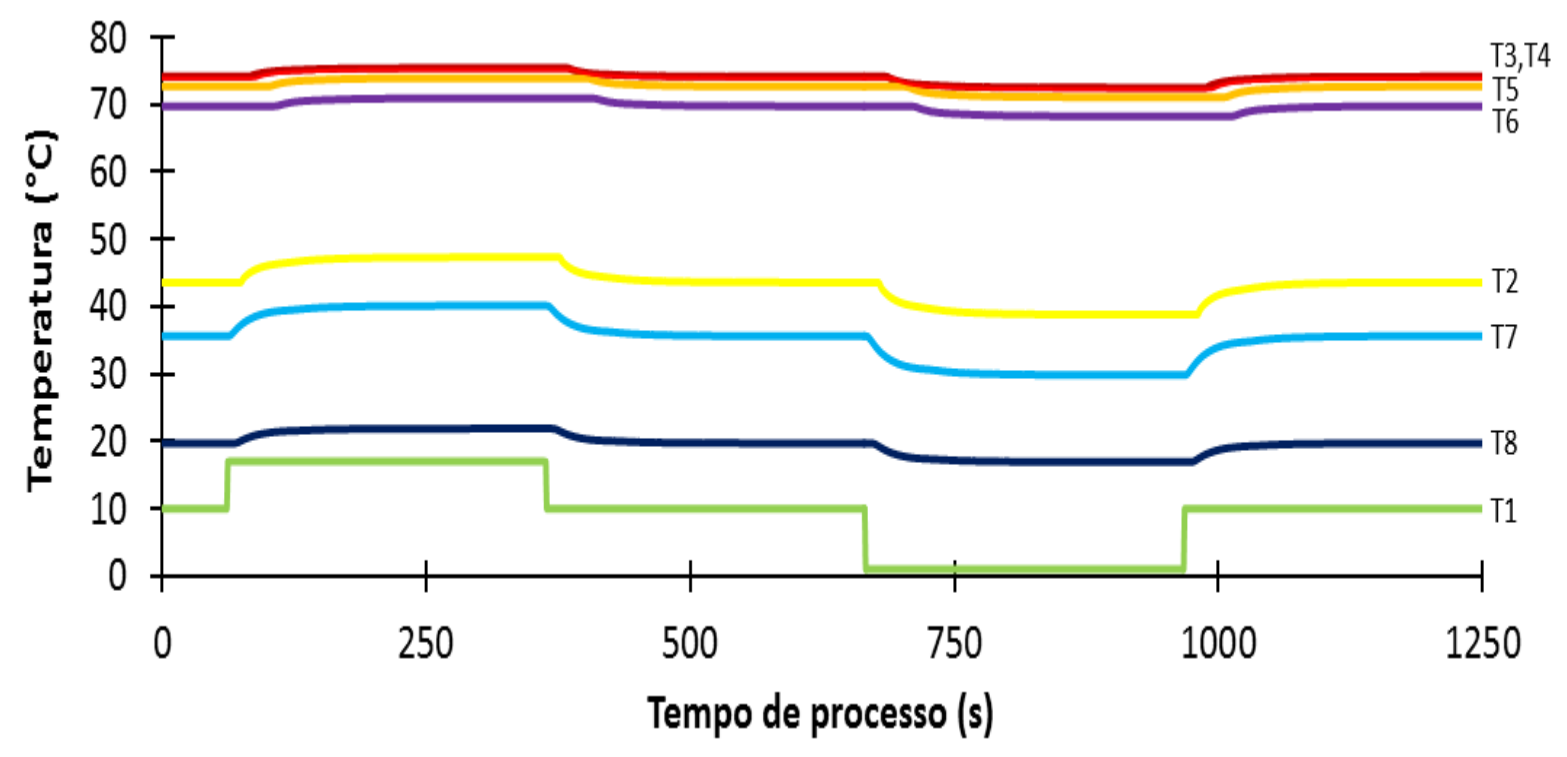

Para as Figuras 6.14 até a 6.17, cada vez que o sistema era perturbado, novos perfis de temperatura eram atingidos, sendo que, o tempo gasto para que isto ocorresse representa a permanência do processo em estado transiente, aproximadamente $200 \mathrm{~s}$ de duração até atingir o novo estado estacionário.

As Figuras 6.16 e 6.19 indicam que, cada vez que a temperatura do leite variou, seja por mudança na temperatura da utilidade de aquecimento, seja devido a própria mudança na temperatura de entrada do produto cru, novos perfis de letalidade foram formados. Ou seja, o grau de esterilidade comercial da pasteurização é diretamente afetado pela temperatura do leite e indiretamente influenciado pela temperatura da água. Nota-se também que pequenas variações na temperatura do leite ao longo do processo, causaram grandes variações no decaimento logarítmico decimal na concentração da $C$. burnetii. Logo, isso deixa explícito que o grau de destruição microbiana é muito sensível a qualquer alteração na temperatura do leite. 
Figura 6.19 - Distribuição da letalidade ao tratamento térmico simulado ao longo do tempo da simulação das perturbações na temperatura de entrada do leite cru.

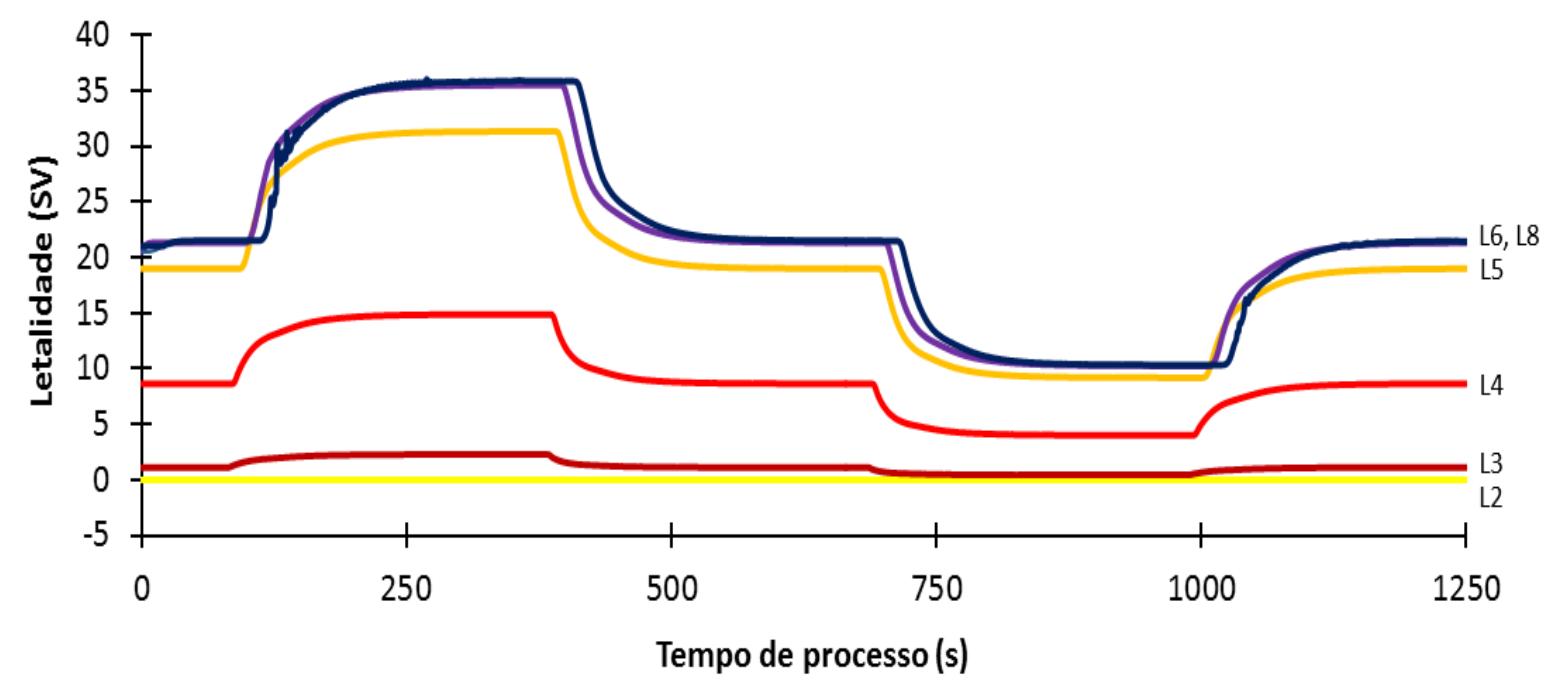

Comparando-se os perfis de temperatura do leite, seja pela perturbação na temperatura de entrada do leite cru (Figura 6.18), seja pela perturbação na temperatura da utilidade de aquecimento (Figura 6.14), nitidamente tem-se maiores variações no histórico de temperatura do leite para casos de perturbações na utilidade e, consequentemente, maiores oscilações no grau de letalidade do tratamento simulado (Figuras 6.16 e 6.19). Como exemplo, tem-se que, pela perturbação de aumento da temperatura da entrada do leite cru de 10 para $17^{\circ} \mathrm{C}$, para um $\Delta T=7^{\circ} \mathrm{C}$ (Figura 6.18), resultou em uma variação para mais, igual a $S V=15(35 \rightarrow 21)$ para letalidade do produto, como visto na Figura 6.19. Seguindo o mesmo raciocínio, só que para água de aquecimento, tem-se que para a perturbação de aumento da temperatura do leite, devido ao aumento na temperatura da utilidade de $90^{\circ} \mathrm{C}$ para 96 ${ }^{\circ} \mathrm{C}$, para um $\Delta T=6{ }^{\circ} \mathrm{C}$ (Figura 6.14), obteve-se uma variação para mais, equivalente a $S V=82(21 \rightarrow 103)$ para letalidade do produto, como visto na Figura 6.16.

\subsubsection{Vazão da Utilidade de Aquecimento}

Pelas Figuras 6.20 e 6.21 têm-se os históricos de temperatura do leite e da letalidade do processo quando perturbações, causadas por mudanças na vazão da utilidade de aquecimento, ocorreram ao longo da pasteurização. As indicações T1, T2, T3, T4, T5, T6, T7 e T8, correspondem aos pontos de controle representativos do processo, sendo estes pontos já mostrados e descritos na Figura 4.1 e no item 4.3.1, 
do capítulo de Modelagem. Já as indicações L2, L3, L4, L5, L6, L7 e L8 referem-se ao decaimento logarítmico decimal na concentração da bactéria-alvo $(S V)$ na entrada da seção de aquecimento, na entrada e na saída da seção de aquecimento, e assim por sucessivamente, como visto anteriormente.

Figura 6.20 - Histórico de temperatura do leite ao longo do tempo de processo da simulação das perturbações na vazão da utilidade de aquecimento.

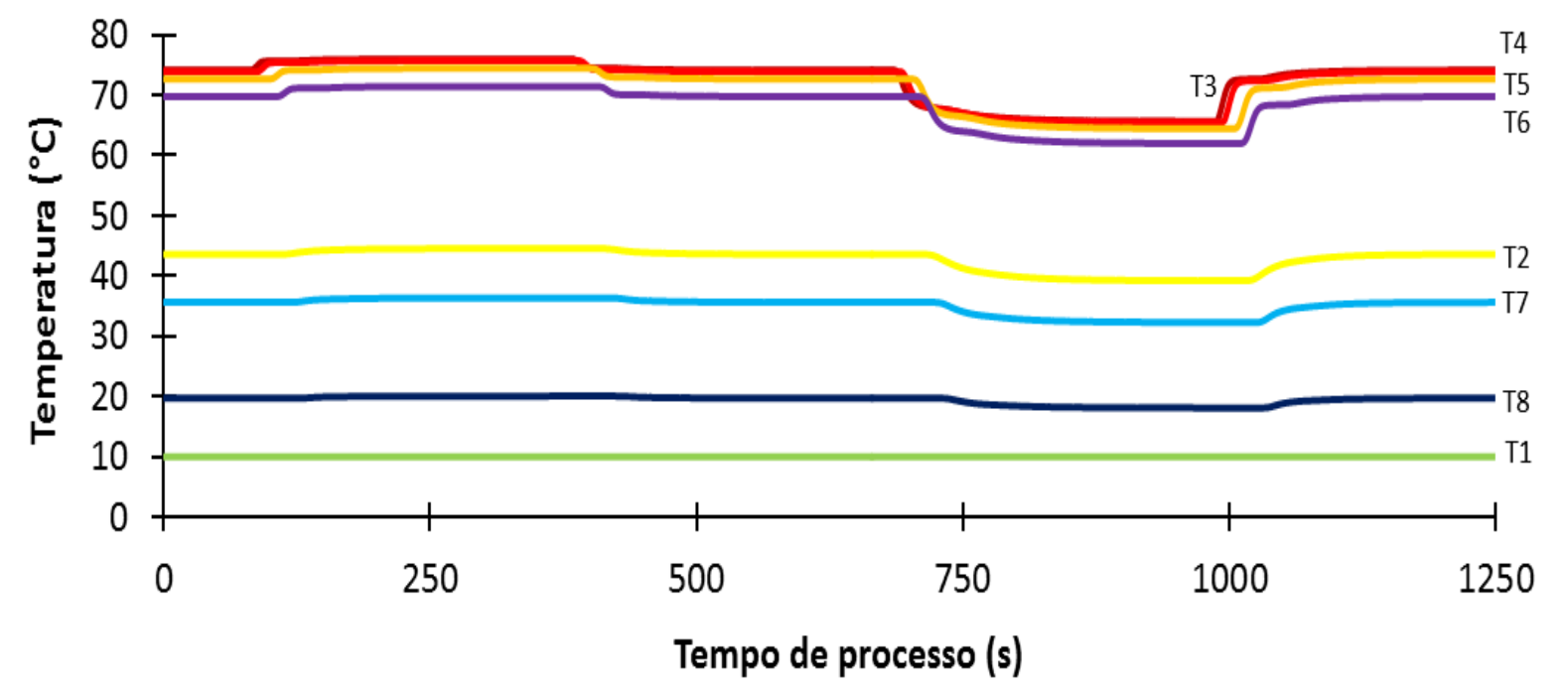

Os parâmetros operacionais usados para estes casos podem ser vistos na Tabela 5.8 da Seção 5.5. Inicialmente o processo foi simulado em sua condição estável, seguido de uma perturbação de aumento no valor da vazão da utilidade de aquecimento. Na sequência, após o sistema ter sido estabilizado novamente, uma perturbação de diminuição na vazão da água de aquecimento foi aplicada ao sistema, sendo que, após certo período de tempo, o processo foi restaurado.

Percebe-se que sempre que ocorre uma perturbação na vazão da utilidade de aquecimento, tanto para valores mais altos ( $250 \mathrm{~s}$ ) quanto para valores mais baixos ( $900 \mathrm{~s}$ ), novos perfis de temperatura eram formados após curto período de tempo, em todas as seções e nos tubos do pasteurizador. Como já relatado anteriormente, essas mudanças são mais significativas na seção de aquecimento e nos tubos.

Gutierrez et al. (2014) obtiveram resultados similares quando simularam e validaram as perturbações nos modelos dinâmicos, de uma unidade de pasteurização a placas, também em gPROMS, porém sem levar em conta os efeitos de letalidade. 
Figura 6.21 - Distribuição da letalidade ao tratamento térmico simulado ao longo do tempo da simulação das perturbações na vazão da utilidade de aquecimento.

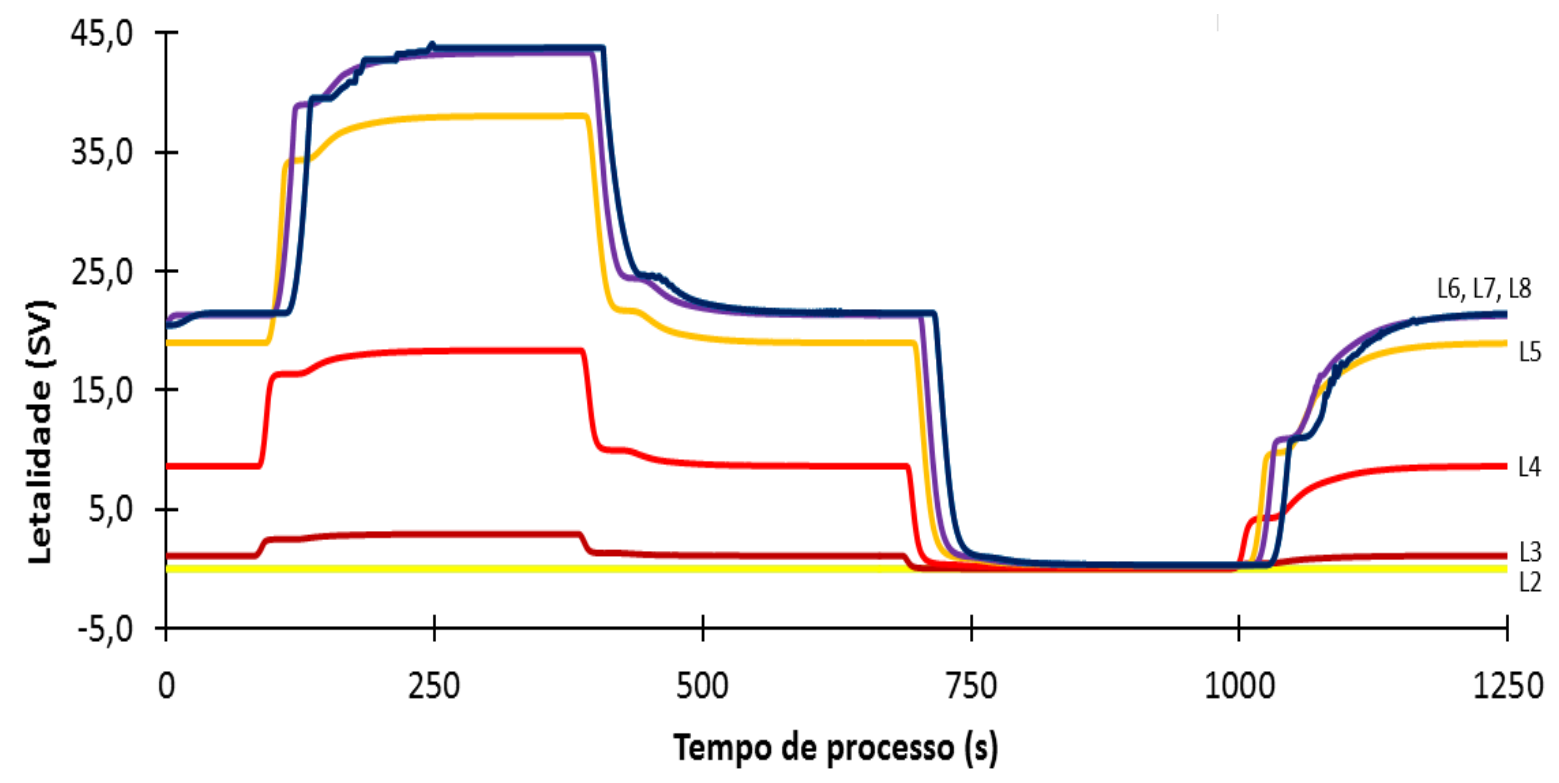

Pela Figura 6.21, fica evidente que, cada vez que o perfil de temperatura do leite era afetado pela perturbação da vazão de aquecimento, novas distribuições de letalidade eram obtidas ao longo do tempo. Então, à medida que a vazão da utilidade de aquecimento aumenta, a temperatura do leite também o faz ( $250 \mathrm{~s})$, e que quando a vazão diminui, isso também ocorre ( 900 s). Isso é observado porque quanto maior a vazão da utilidade, maior será a taxa de transferência de calor para o produto, sendo a recíproca verdadeira. Como consequência, isso é repercutido no grau de esterilização do tratamento térmico (letalidade). Ou seja, quanto maior a vazão da utilidade, maior será a destruição microbiana e vice-versa.

Outro ponto importante é que as variações dos perfis de temperatura do leite, quando o sistema é perturbado na vazão de água quente, tanto para mais como para menos, não são iguais. Isto é, no primeiro caso tem-se uma perturbação de $60 \mathrm{~L} / \mathrm{h}$ para $100 \mathrm{~L} / \mathrm{h}(\Delta \dot{V}=40 \mathrm{~L} / \mathrm{h})$ na vazão da utilidade, causando uma oscilação de $73,9^{\circ} \mathrm{C}$ para $75,7^{\circ} \mathrm{C}\left(\Delta T=1,8^{\circ} \mathrm{C}\right)$ na temperatura do leite, na entrada do tudo de retenção. Já para o caso de diminuição da vazão de aquecimento de $60 \mathrm{~L} / \mathrm{h}$ para $20 \mathrm{~L} / \mathrm{h}(\Delta \dot{V}=$ $40 \mathrm{~L} / \mathrm{h})$, tem-se uma variação na temperatura do leite de $73,9^{\circ} \mathrm{C}$ para $65,5^{\circ} \mathrm{C}(\Delta T=$ $8,4^{\circ} \mathrm{C}$ ), como visto na Figura 6.20.

De acordo com Hasting (1992) e lbarrola et al. (2002), o desvio de $1^{\circ} \mathrm{C}$ na temperatura do processo, produz um erro de até $25 \%$ no efeito de pasteurização, tanto para mais quanto para menos do que o dimensionado. 
Neste trabalho, os dados mostraram que, por exemplo para o caso de perturbação da vazão de aquecimento, quando a temperatura subiu de $73,9^{\circ} \mathrm{C}$ para $74,8^{\circ} \mathrm{C}\left(\Delta T \cong 1,0^{\circ} \mathrm{C}\right)$, na entrada do tubo de retenção, a letalidade $(S V)$ variou de 8,6 para $S V=14,4(\Delta S V \cong 6)$. Em outras palavras, isso representa que o desvio de $1{ }^{\circ} \mathrm{C}$ na temperatura do produto causa um desvio de aproximadamente $69 \%$, para mais, no efeito da pasteurização.

Fazendo a mesma análise, só que considerando o desvio do processo para menos, tem-se que, por exemplo, pela Figura 6.20, do instante $t=650 \mathrm{~s}$ (sem perturbação) a temperatura do leite na entrada do tubo de retenção foi de $73,9^{\circ} \mathrm{C}$ para $65,5^{\circ} \mathrm{C}$ no instante $t=950 \mathrm{~s}$ (com perturbação de diminuição na vazão de água quente). Isso, representa uma variação de 8,5 na letalidade $(S V)$ do tratamento térmico, simbolizando um desvio de $99 \%$, para menos, no efeito da pasteurização.

Esses resultados mostram o quão crítico é o correto controle da temperatura de pasteurização do produto (da vazão da utilidade de aquecimento), pois uma variação neste parâmetro poderá afetar significativamente o resultado final da inocuidade do alimento.

As Figuras 6.22 e 6.23, a partir das Figuras 6.20 e 6.21, mostram em detalhe os degraus na distribuição da temperatura (T3, T4, T5 e T6) e no histórico da letalidade (L3, L4, L5 e L6), durante os instantes $t=350 \mathrm{~s}$ e $t=850 \mathrm{~s}$ do processo, quando perturbações na vazão de entrada da água quente foram impostas no sistema.

Figura 6.22 - Detalhamento dos degraus no histórico de temperatura do leite em T3, T4, T5 e T6 da simulação das perturbações na vazão da utilidade de aquecimento.

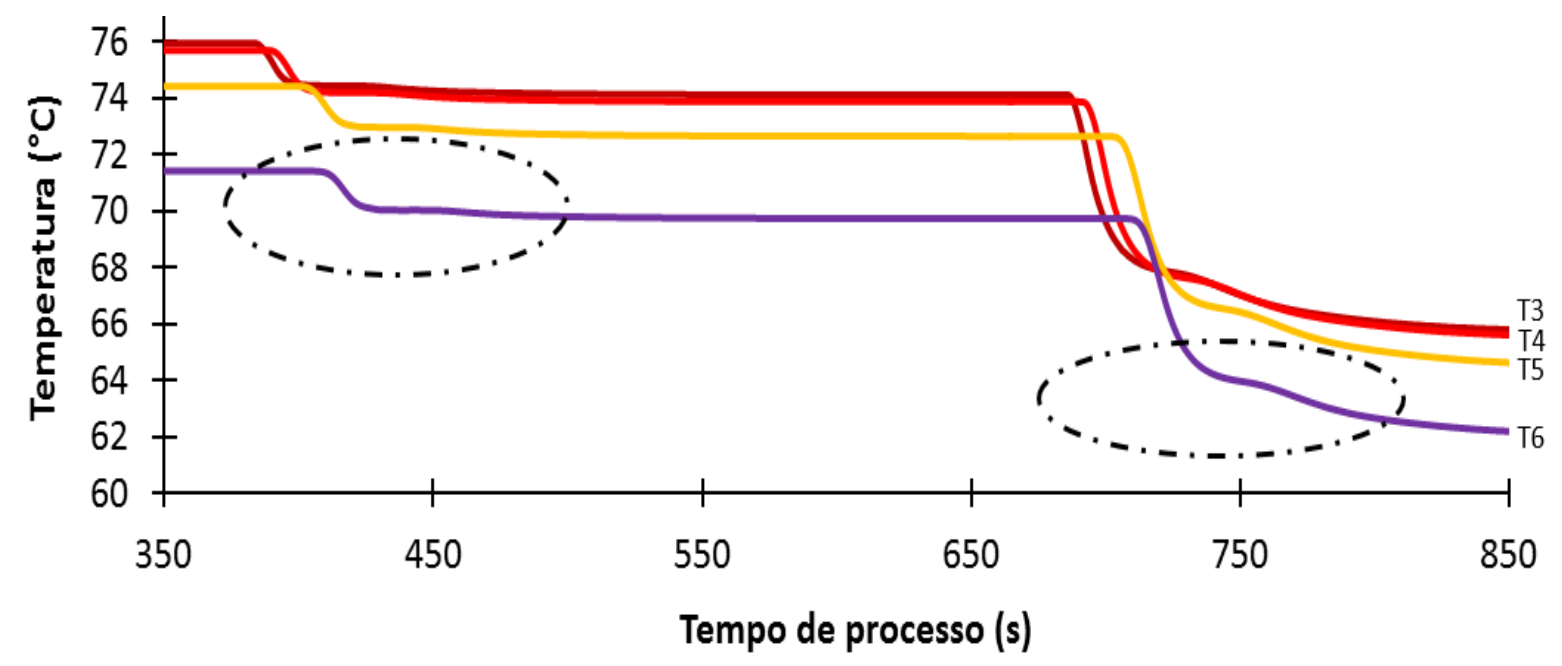


Figura 6.23 - Detalhamento dos degraus da distribuição da letalidade em L6, L5, L4 e L3 da simulação das perturbações na vazão de entrada da utilidade de aquecimento.

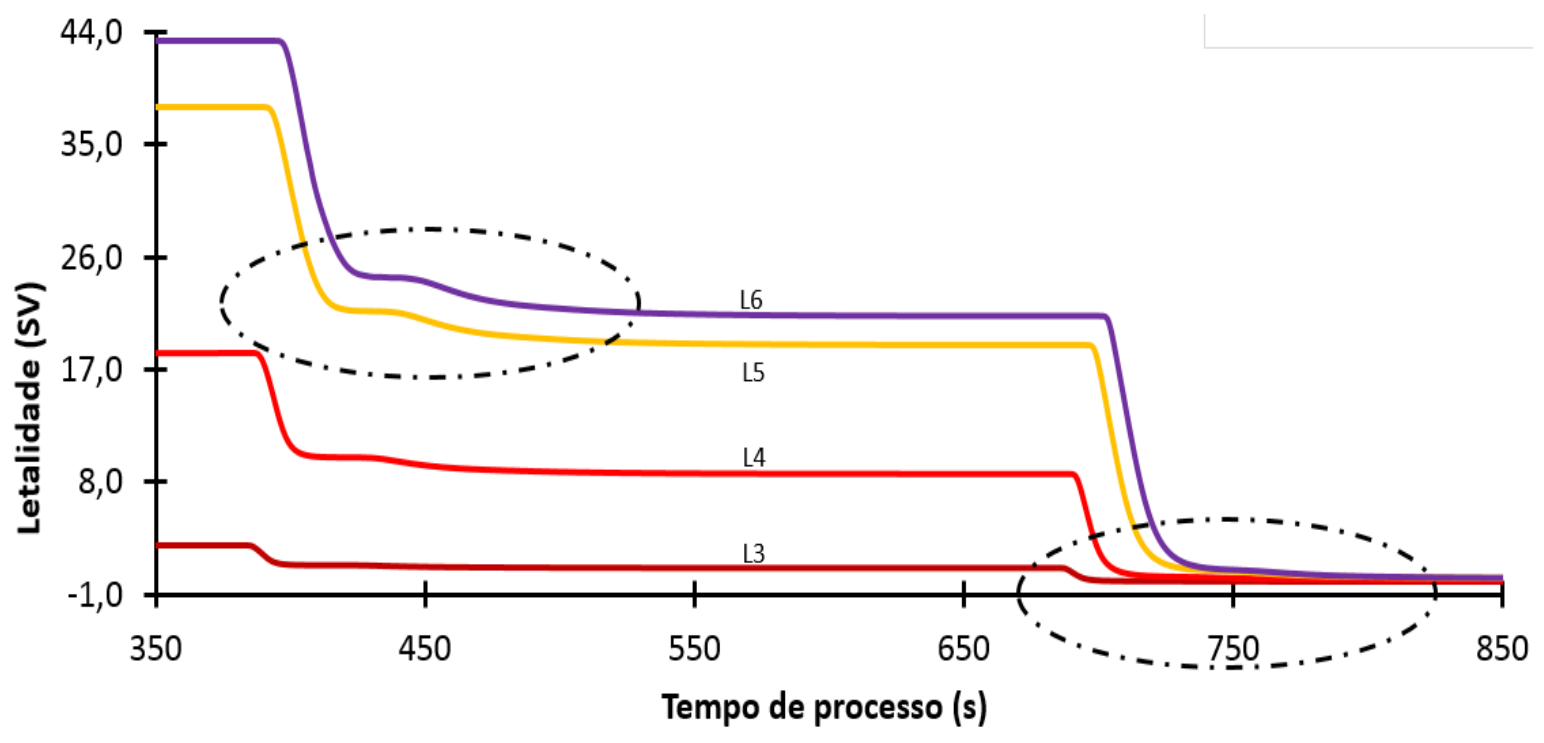

Variações na temperatura do leite são suficientes para causar oscilações significativas na letalidade do tratamento térmico, sendo isso válido para todas as seções do equipamento, mas, principalmente, na seção de aquecimento e no tubo de retenção, os quais são responsáveis pela redução da carga microbiana do leite. Essa diminuição do efeito letal, ocasionada por variações na temperatura do leite direta ou indiretamente, mesmo que sutil, pode conduzir a falta de inocuidade do produto final.

\subsubsection{Vazão e Temperatura da Utilidade de Aquecimento e do Leite Cru}

Os resultados obtidos para simulação do processo de pasteurização do leite com perturbações simultâneas na vazão e na temperatura da utilidade de aquecimento e na temperatura de entrada do produto cru, ao mesmo tempo, são mostradas nas Figuras 6.24 a 6.26. As indicações T1, T2, T3, T4, T5, T6, T7 e T8 correspondem aos pontos de controle representativos do processo, sendo estes pontos já mostrados e descritos na Figura 4.1 e no item 4.3.1, do capítulo de Modelagem, bem como as indicações L2, L3, L4, L5, L6, L7 e L8, que se referem ao decaimento logarítmico decimal na concentração da bactéria $C$. burnetti, ao longo das seções do equipamento. 
Figura 6.24 - Histórico de temperatura do leite ao longo do processo da simulação das perturbações na vazão e na temperatura da utilidade de aquecimento e na temperatura de entrada do leite cru ao mesmo tempo.

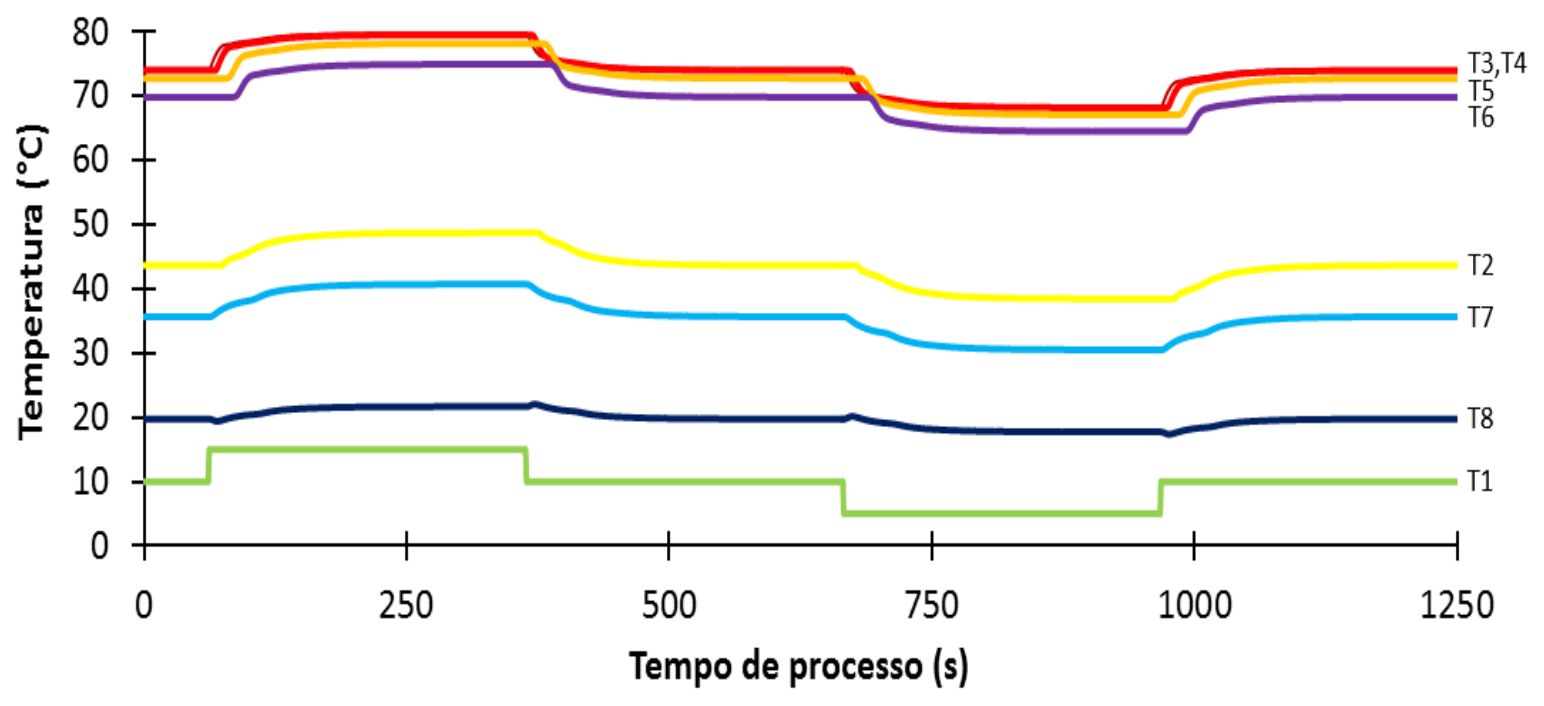

Novamente, os parâmetros operacionais usados para estes casos podem ser vistos na Tabela 5.14 da Seção 5.5. De início o processo foi simulado em sua condição normal, sendo imposta uma perturbação de aumento dos valores das variações: vazão e temperatura da utilidade de aquecimento e na temperatura de entrada do leite cru. Após certo período de tempo de processo, o sistema foi estabilizado novamente, seguido por outra perturbação - diminuição dos valores das mesmas variáveis. Por fim, o processo volto a sua condição inicial.

As perturbações de aumento da vazão e de temperatura da utilidade de aquecimento e da temperatura do leite, juntas, afetam mais ainda os perfis de temperatura do leite, pois, como visto nos casos anteriores, a quantidade de calor transferida ao produto é maior. Então, neste caso, os efeitos se somam. De modo contrário, para perturbação de diminuição destes parâmetros operacionais, haverá diminuição nos perfis de temperatura do leite.

Para cada perturbação, o processo leva em média $200 \mathrm{~s}$ para atingir o novo estado estacionário e as maiores variações também são nas seções de aquecimento e retenção do pasteurizador. Entretanto, os perfis de temperatura do leite ao longo do processo, quando perturbados pelo efeito concomitante da vazão e temperatura da utilidade e do produto, são ligeiramente diferentes dos casos de perturbação em uma única variável deste tipo. Isso é mais perceptível em T2, T7 e T8, na Figura 6.24. 
Figura 6.25 - Distribuição da letalidade ao tratamento térmico simulado ao longo do tempo da simulação das perturbações na vazão e temperatura da utilidade de aquecimento e na temperatura de entrada do leite cru ao mesmo tempo.

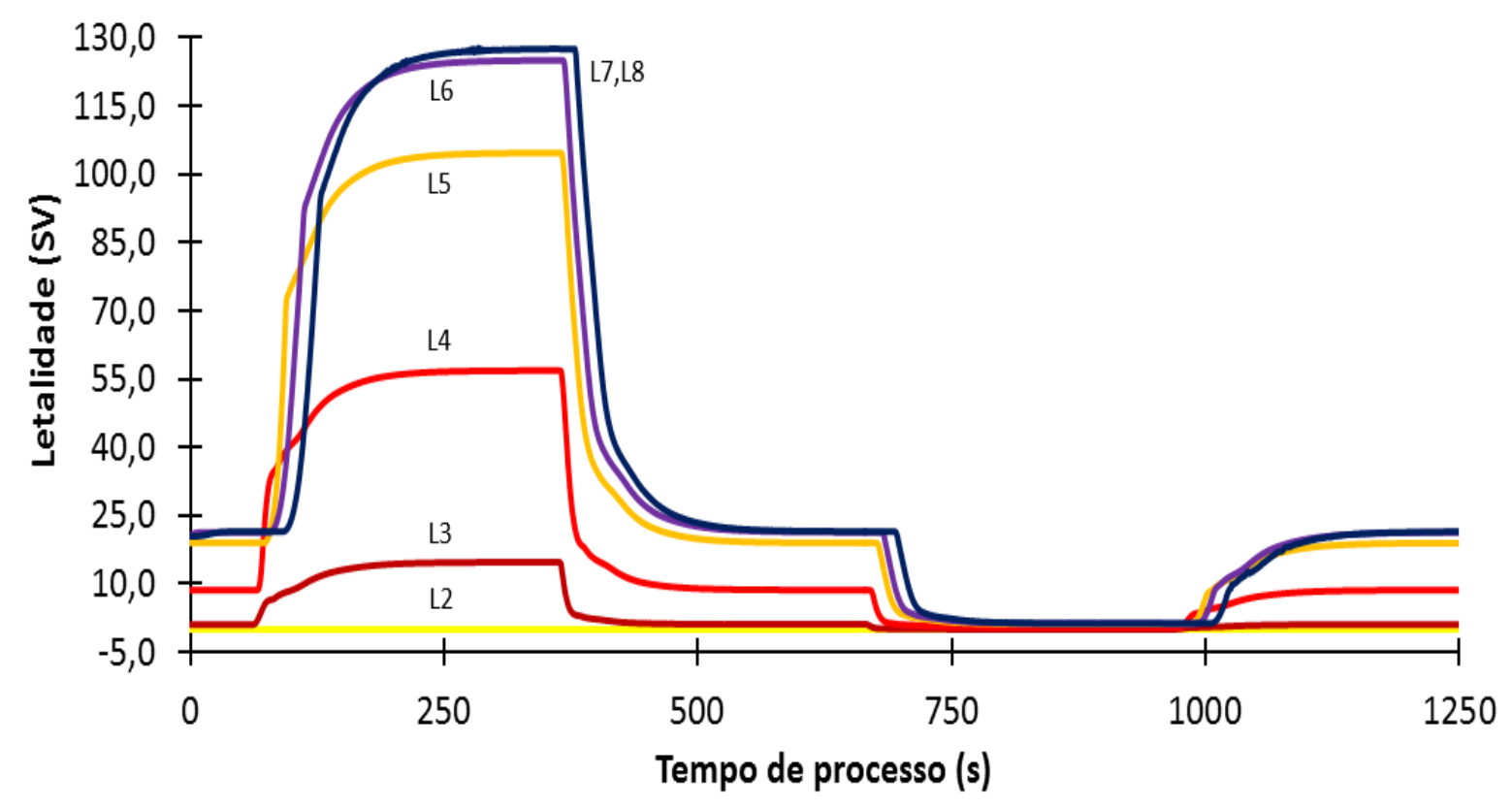

Pela Figura 6.25, considerando apenas a perturbação 1 (instante $t \cong 250 \mathrm{~s}$ ), de aumento das três variáveis operacionais, a letalidade $(S V)$ final do processo chega até 128. Ou seja, a destruição microbiana foi extremamente intensa devido a maior quantidade de calor transferida ao leite. Contudo, industrialmente falando, este tratamento térmico estaria aquém do necessário, havendo, então, o indesejável sobreprocessamento do produto. Todavia, considerando apenas a perturbação 2 (instante $t \cong 900 \mathrm{~s}$ ), o fenômeno é contrário - subprocessamento do leite. Neste caso, a letalidade $(S V)$ do processo não chegou a 5 , comprometendo a segurança do produto.

Uma análise da distribuição da concentração da C. burnetii pelo tempo e espaço, dentro do canal 11, da seção de aquecimento do trocador de calor, considerando este cenário de perturbação no sistema, é mostrada na Figura 6.26.

Em relação ao tempo, o primeiro valor do gráfico $(t \cong 60 \mathrm{~s})$ representa a diminuição da concentração da $C$. burnetii devido à maior destruição térmica ocasionada pelo aumento da vazão e temperatura de água quente e do leite de entrada no sistema. Já o pico $(t \cong 900 \mathrm{~s})$ representa uma diminuição na taxa de destruição da bactéria devido à reduzida inativação térmica ocasionada pela queda destes parâmetros operacionais. Logo, a concentração de micro-organismos 
permaneceu praticamente inalterada, pois pouca quantidade de calor foi transferida ao leite.

Figura 6.26 - Distribuição da concentração microbiana $(\mathrm{UFC} / \mathrm{mL})$ da $C$. burnetii ao longo tempo e do espaço adimensionalizado, no canal 11 da seção de aquecimento, quando o sistema sofreu perturbações na vazão e temperatura da utilidade de aquecimento e na temperatura de entrada do leite cru ao mesmo tempo.

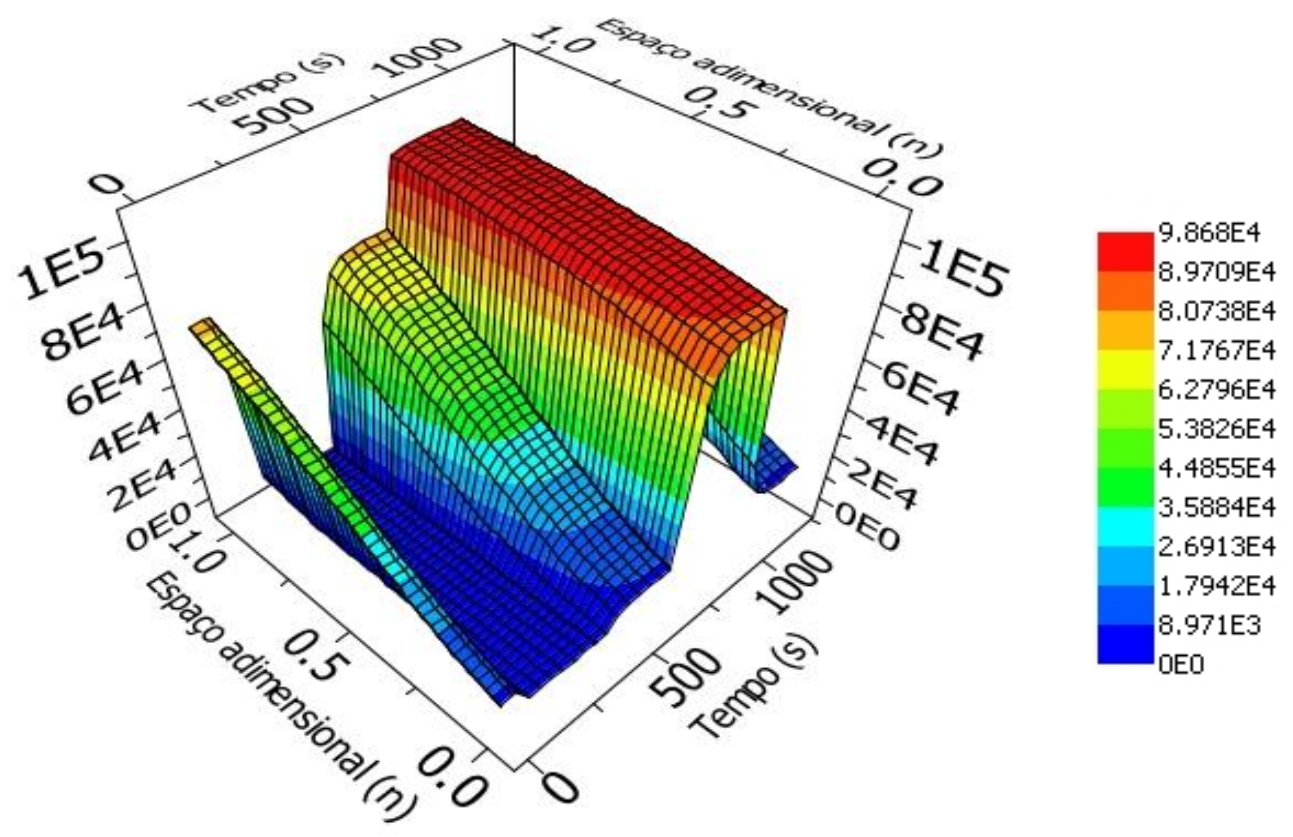

De acordo com o espaço discretizado e adimensionalizado, tem-se a redução na concentração microbiana na direção do escoamento como consequência do aumento da temperatura do leite na mesma referência. Por exemplo, em relação à Figura 6.26, o escoamento do produto é no sentido de $\eta=1,0$ (entrada do canal 11) para $\eta=0,0$ (saída do canal 11) bem como a diminuição da concentração microbiológica.

\subsection{Pasteurização Sujeita à Incrustação}

Os resultados referentes à simulação do processo contínuo da pasteurização do leite bovino sujeito à incrustação são observados nas Figuras 6.27 a 6.32 .

A Figuras 6.27 mostra os perfis do fator de incrustação $\left(R_{f}\right)$ e o coeficiente global de transferência de calor total $\left(U_{t}\right)$, ao longo do tempo de processo, na seção de aquecimento do PHE do pasteurizador. Para este caso, o processo foi simulado a 
partir do estado estacionário seguindo o cenário da Tabela 5.12, porém, considerando o fenômeno da incrustação do leite no equipamento.

Figura 6.27 - Distribuição do fator de incrustação $\left(R_{f}\right)$ e do coeficiente global de transferência de calor total $\left(U_{t}\right)$, na seção de aquecimento, durante a pasteurização do leite sujeita à incrustação.

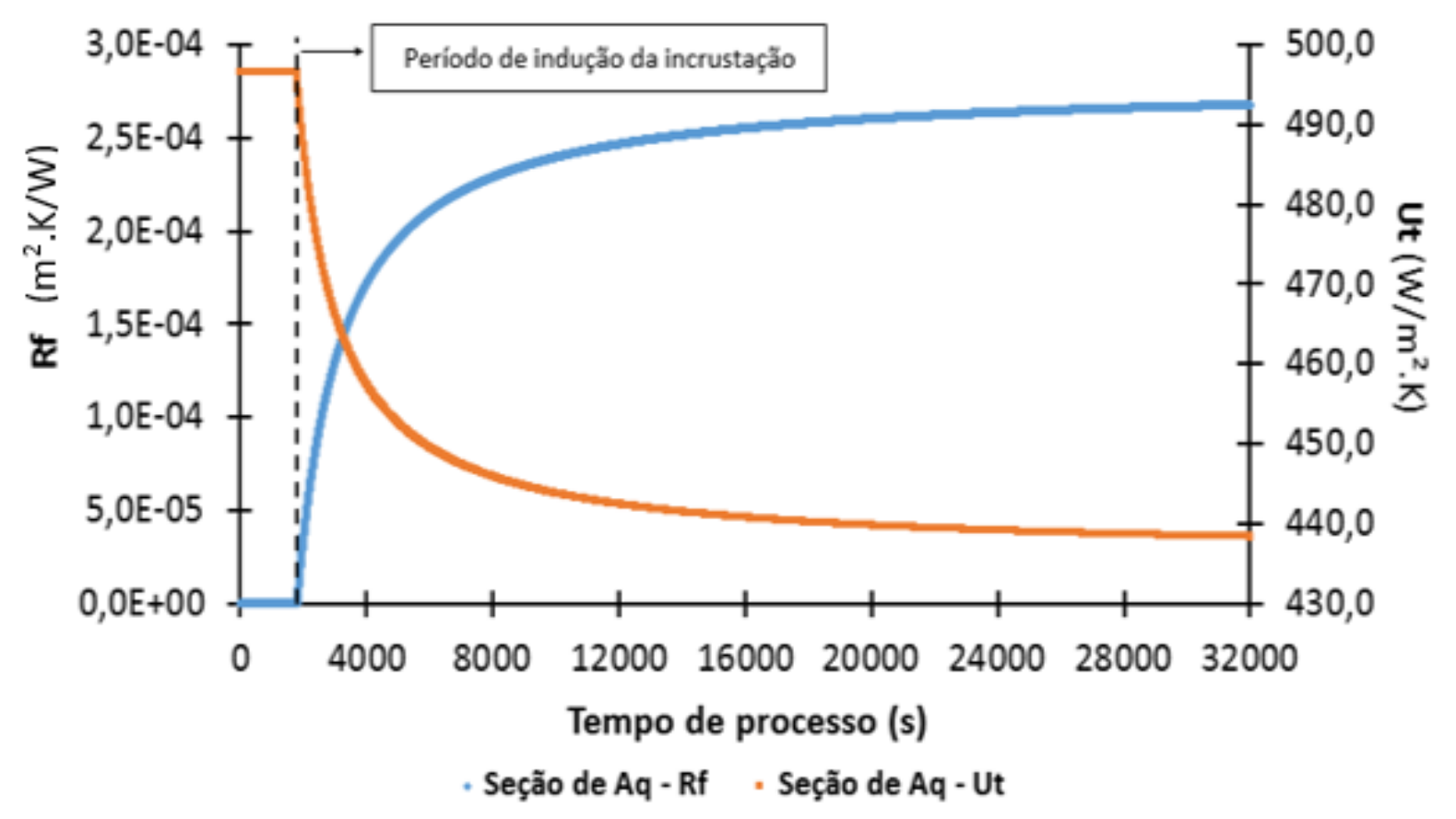

Pelos resultados deste caso, percebe-se que o valor do coeficiente global de transferência de calor $\left(U_{t}\right)$ varia ao longo do tempo de processo - linha em laranja. $O$ motivo pela qual isso ocorre é devido ao surgimento do fator de incrustação $\left(R_{f}\right)$ linha em azul. Isto é, a camada de material depositada nas placas acrescenta um termo a mais na equação do coeficiente global de transferência de calor $\left(U_{t}\right)$, a resistência térmica de condução desta camada. Ainda sobre a Figura 6.27, observase que o tempo de indução do início do fenômeno da incrustação foi de $1800 \mathrm{~s}$, sendo que, até esse instante do processo, o valor do coeficiente global de transmissão de calor $\left(U_{t}\right)$ tem o seu valor máximo $\left(497 \mathrm{~W} / \mathrm{m}^{2} . \mathrm{K}\right)$ e o fator de incrustação $\left(R_{f}\right)$ tem o seu valor mínimo (zero).

O fenômeno da incrustação do produto nas placas do PHE de aquecimento é algo indesejável uma vez que reduz a eficiência energética das trocas térmicas entre o leite e a utilidade quente. Por exemplo, nesse caso, o valor do coeficiente global de transmissão de calor foi de $497 \mathrm{~W} / \mathrm{m}^{2} . \mathrm{K}$, considerando o equipamento limpo no 
instante $t=0 \mathrm{~s}$, para $438 \mathrm{~W} / \mathrm{m}^{2} . \mathrm{K}$, com o equipamento sujo no instante $t=32000 \mathrm{~s}$. Ou seja, isso representa uma queda de $12 \%$ no valor do coeficiente global de transferência de calor do processo.

Diversos autores encontraram resultados semelhantes aos deste trabalho com relação aos perfis de $R_{f}$ e $U_{t}$ para leite bovino, só que simulando apenas em um PHE (GEORGIADIS, MACCHIETTO, 2000; JUN, PURI, 2006; MAHDI et al., 2009), e não para o pasteurizador todo. O mesmo também é válido para leite de coco (PICHITVITTAYAKARN et al., 2006) e água fresca com carbonato de cálcio (KAPUSTENKO et al., 2012). Perfis com comportamento similar ao da Figura 6.27 também foram obtidos em trocador de calor tubular com leite (PETERMEIER et al., 2002) e em uma unidade de secagem de leite, com período de indução de até 2 horas após o início do processamento (BENNETT, 2007).

Kapustenko et al. (2012) analisaram dados experimentais do fator de incrustação de solução de carbonato de cálcio e água em PHE e em canais anulares de acordo com vários trabalhos da literatura e compararam os resultados teóricos de seus modelos, para tempo de processo de 30 a 100 horas, considerando diferentes velocidades de escoamento e temperaturas de processo. Os dados teóricos e os experimentais apresentam tendências similares às obtidas neste trabalho, exceto pelo fato do tempo de indução dos autores ser próximo de zero. O estudo mostrou que quanto maior a velocidade do escoamento, menor o fator de incrustação do processo em razão da maior taxa de cisalhamento e menor tempo de contato entre o fluido e a superfície de aquecimento. Também foi observado que quanto maior a temperatura do produto, maior o valor do fator de incrustação.

Embora não tenha sido computado na modelagem deste trabalho, outro efeito indesejável da incrustação nos tubos é o estreitamento da área de escoamento do produto - também ocorre nos canais do PHE de aquecimento -, oriundo da formação de depósitos na parede de troca térmica, resultando num aumento da velocidade do leite e modificando o seu perfil. Como consequência, isso afetará o valor do número de Reynolds e poderá diminuir o tempo de permanência do produto na retenção, levando ao seu subprocessamento (NDOYE et al., 2012). Todavia, esse efeito foi desprezado na modelagem desenvolvida neste trabalho.

Belmar-Beiny et al. (1993) investigaram a influência da incrustação das proteínas do leite bovino, durante o tratamento térmico, no número de Reynolds, porém em trocador de calor tubular. Os autores processaram fluido simulado com $35 \%$ de 
proteína láctea concentrada e seus resultados experimentais indicaram que a incrustação do equipamento causou uma diminuição significativa no número de Re de 6000 para 2000, ao longo do tempo.

$\mathrm{O}$ aparecimento gradativo de uma camada de material aderido às placas do PHE de aquecimento, ao longo do tempo de processo, é oriundo do fenômeno da incrustação do leite no pasteurizador. Então, à medida que o processo se desenrola, o fator de incrustação vai aumentando e, como consequência, o $\left(U_{t}\right)$ sofre uma crescente diminuição (Figuras 6.27). Isso resulta numa diminuição dos perfis de temperatura do leite em todas as partes do pasteurizador, exceto na entrada do equipamento (Figura 6.28). Por fim, a taxa de destruição de células microbianas é reduzida, ocasionando menor letalidade ao tratamento térmico (Figura 6.29).

Nesse sentido, na Figura 6.28 tem-se as indicações T1, T2, T3, T4, T5, T6, T7 e T8, que correspondem aos pontos representativos do processo de pasteurização, sendo estes já mostrados e descritos na Figura 4.1 e no item 4.3.1, do capítulo de Modelagem. Nota-se o comportamento dos perfis de temperatura do leite, ao longo do tempo de processo, levando em conta todas as seções do equipamento bem como os tubos do mesmo.

Figura 6.28 - Histórico de temperatura do leite ao longo do tempo de processo da simulação da pasteurização do leite sujeita à incrustação.

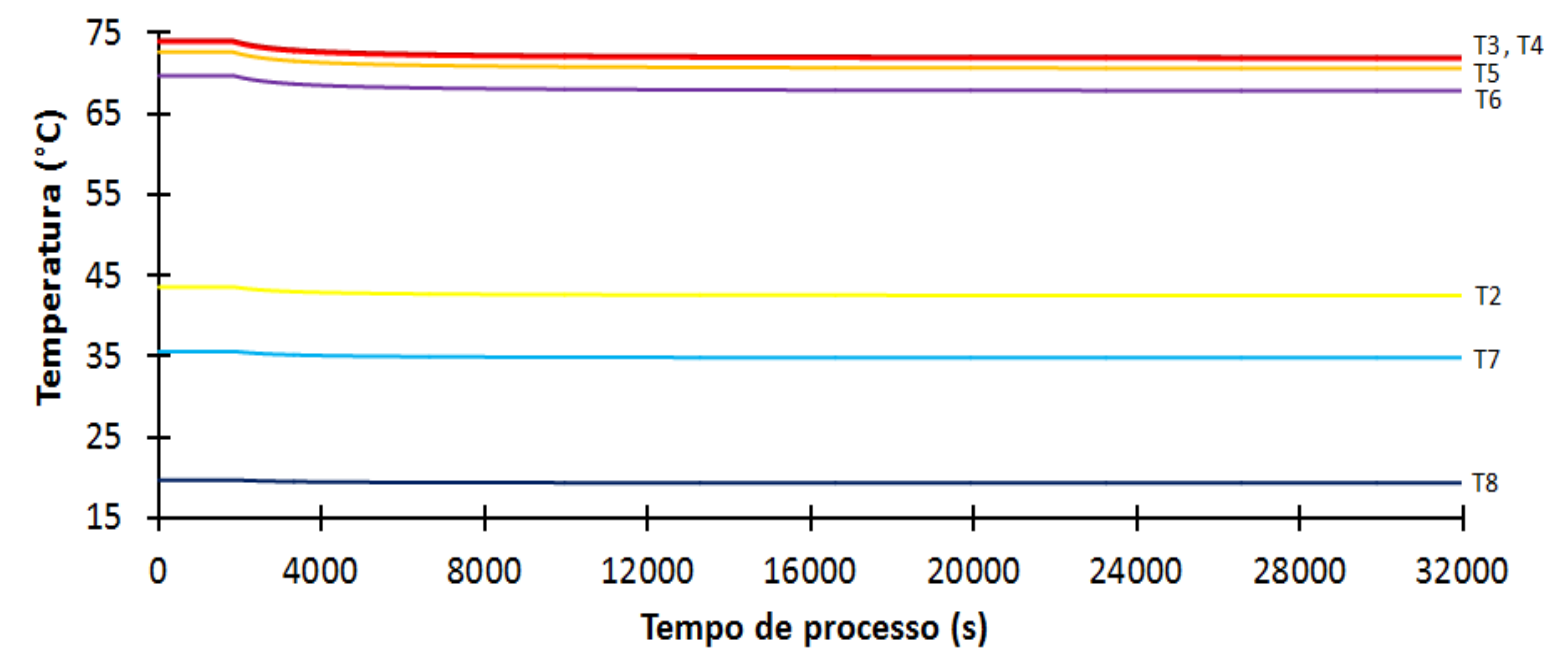

Percebe-se que a temperatura do produto, ao longo do tempo de processo, diminui gradativamente em virtude do fenômeno da incrustação. Isto é válido em todo o pasteurizador, como resultado da seção de aquecimento, sendo esta variação mais 
intensa até $\mathrm{o}$ instante $t=8000 \mathrm{~s}$. Por exemplo, em T2 (entrada da seção de aquecimento) a temperatura do leite no início do processo, instante $t=0 \mathrm{~s}$, é igual a $43,6^{\circ} \mathrm{C}$. Já ao final do processo, ainda em T2, no instante $t=32000 \mathrm{~s}$, a temperatura é equivalente a $42,5{ }^{\circ} \mathrm{C}$. Isto representa um $\Delta T=1,1^{\circ} \mathrm{C}$, considerando apenas o fenômeno da incrustação. Fazendo a mesma análise, mas para T3 (saída da seção de aquecimento), a temperatura do produto no início do processo é igual a $74,1^{\circ} \mathrm{C}$. e ao final do processo (no instante $t=32000 \mathrm{~s}$ ), a temperatura é de $72,0^{\circ} \mathrm{C}$, o que significa um $\Delta T=2,1^{\circ} \mathrm{C}$.

Essas variações de temperatura do leite nas seções quentes do PHE (aquecimento e retenção) devido à sua incrustação nas placas podem ser vistas mais detalhadamente pela Figura 6.29, a qual é oriunda da Figura 6.28.

Figura 6.29 - Histórico de temperatura do leite (T3, T4 e T5) da simulação da pasteurização do leite sujeita à incrustação entre o instante $t=0 \mathrm{~s}$ e $t=12000 \mathrm{~s}$.

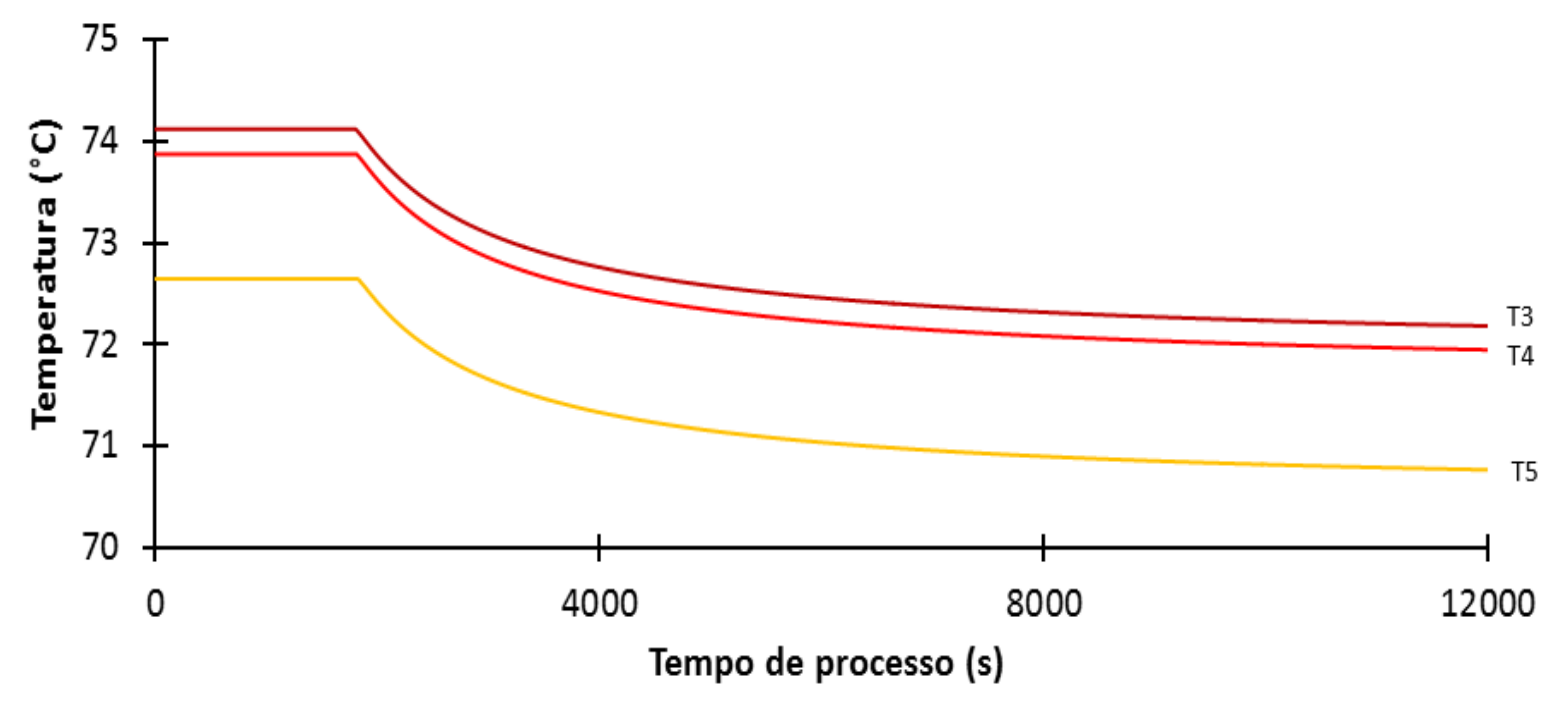

Como o processo foi conduzido em malha aberta, sem atuação de controladores para a temperatura de saída do leite na retenção, e em razão da incrustação do produto, percebe-se a queda em sua temperatura ao longo do tempo. Essa queda tem origem na seção de aquecimento (T3), porém, é repercutida na saída do aquecimento e no tubo de retenção (T4 e T5), e assim por diante. Como pode ser visto na Figura 6.29 , a diminuição na temperatura do produto é mais pronunciada entre os instantes $t=1800 \mathrm{~s}$ e $t=8000 \mathrm{~s}$, pois a queda do valor do coeficiente global de troca térmica também é mais significativa neste período.

Pela inspeção da Figura 6.30 é mostrado o histórico de temperatura da água de aquecimento na entrada (T9) e na saída (T10) da seção quente do PHE durante a 
pasteurização sujeita à incrustação. Percebe-se que, como o leite não consegue absorver uma parte do calor fornecido pela utilidade de aquecimento em decorrência do fenômeno da incrustação, a temperatura de saída da água quente na seção de aquecimento do PHE é crescente ao longo do tempo de pasteurização. Então, como consequência desta queda de transferência de calor ao leite, o grau de letalidade do tratamento térmico será afetado, como pode ser visto na Figura 6.31.

Figura 6.30 - Histórico de temperatura de entrada (T9) e de saída (T10) da utilidade quente na simulação da pasteurização do leite sujeita à incrustação entre os instantes $t=0 \mathrm{~s}$ e $t=12000 \mathrm{~s}$.

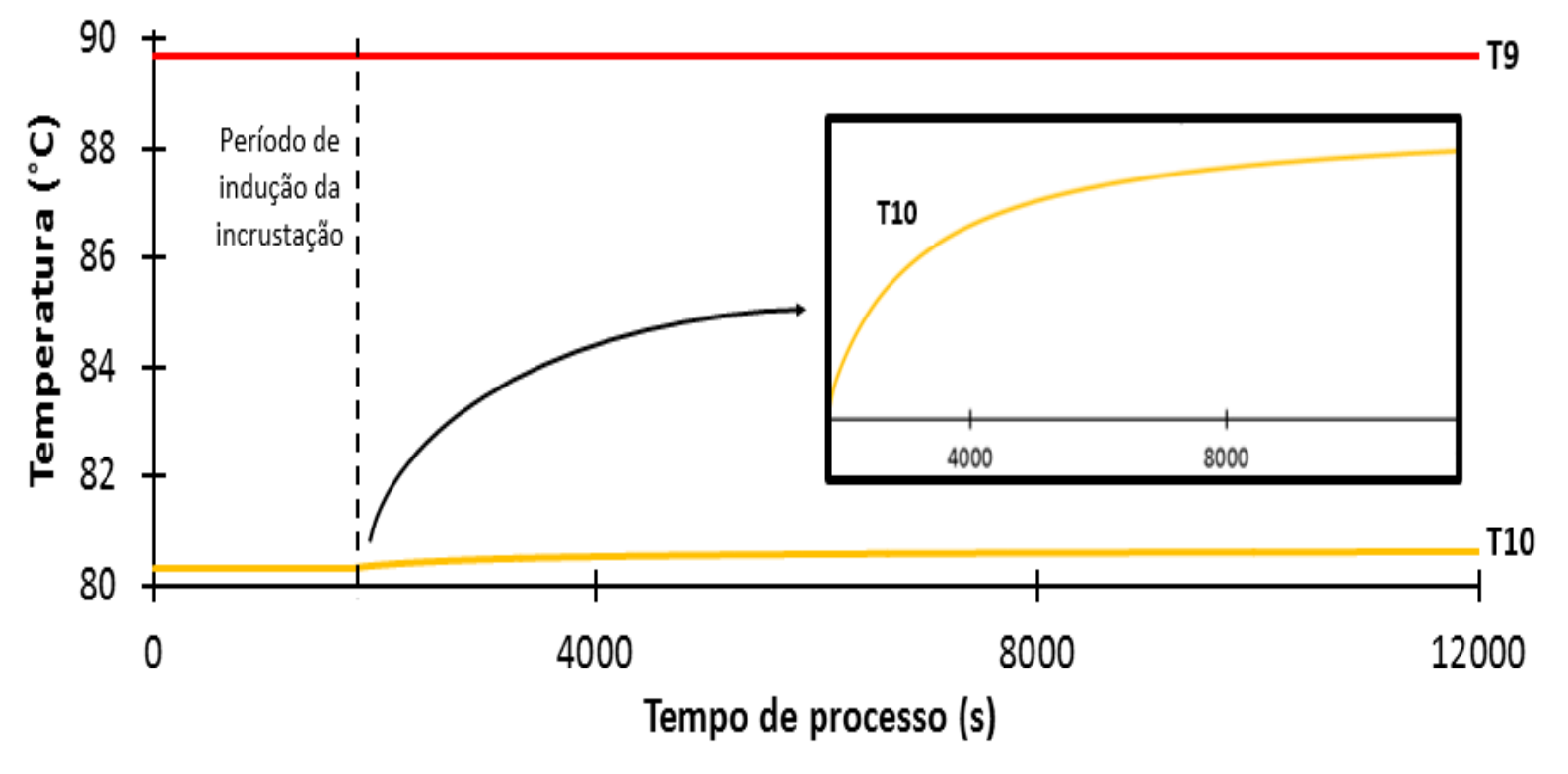

-Entrada da água quente - T9-Saída da água quente - T10

Na Figura 6.31, tem-se variações nos perfis de letalidade do tratamento térmico devido às mudanças nos perfis de temperatura do leite, os quais são oriundos do fenômeno da incrustação do produto, afetando o grau de inocuidade do produto final.

As maiores variações ou oscilações dos perfis de temperatura e letalidade são observadas até $o$ instante $t=12000 \mathrm{~s}$, sendo que, após esse tempo de processo, tem-se a tendência ao regime estacionário. Além disso, nota-se que a incrustação atingiu seu valor máximo por volta do instante $t=32000 \mathrm{~s}$, apresentando os menores valores de letalidade, como consequência do efeito indesejável da queda do coeficiente global de transmissão de calor do processo (Figura 6.27). 
Figura 6.31 - Histórico da letalidade ao tratamento térmico simulado, ao longo do tempo, da simulação da pasteurização do leite sujeita à incrustação.

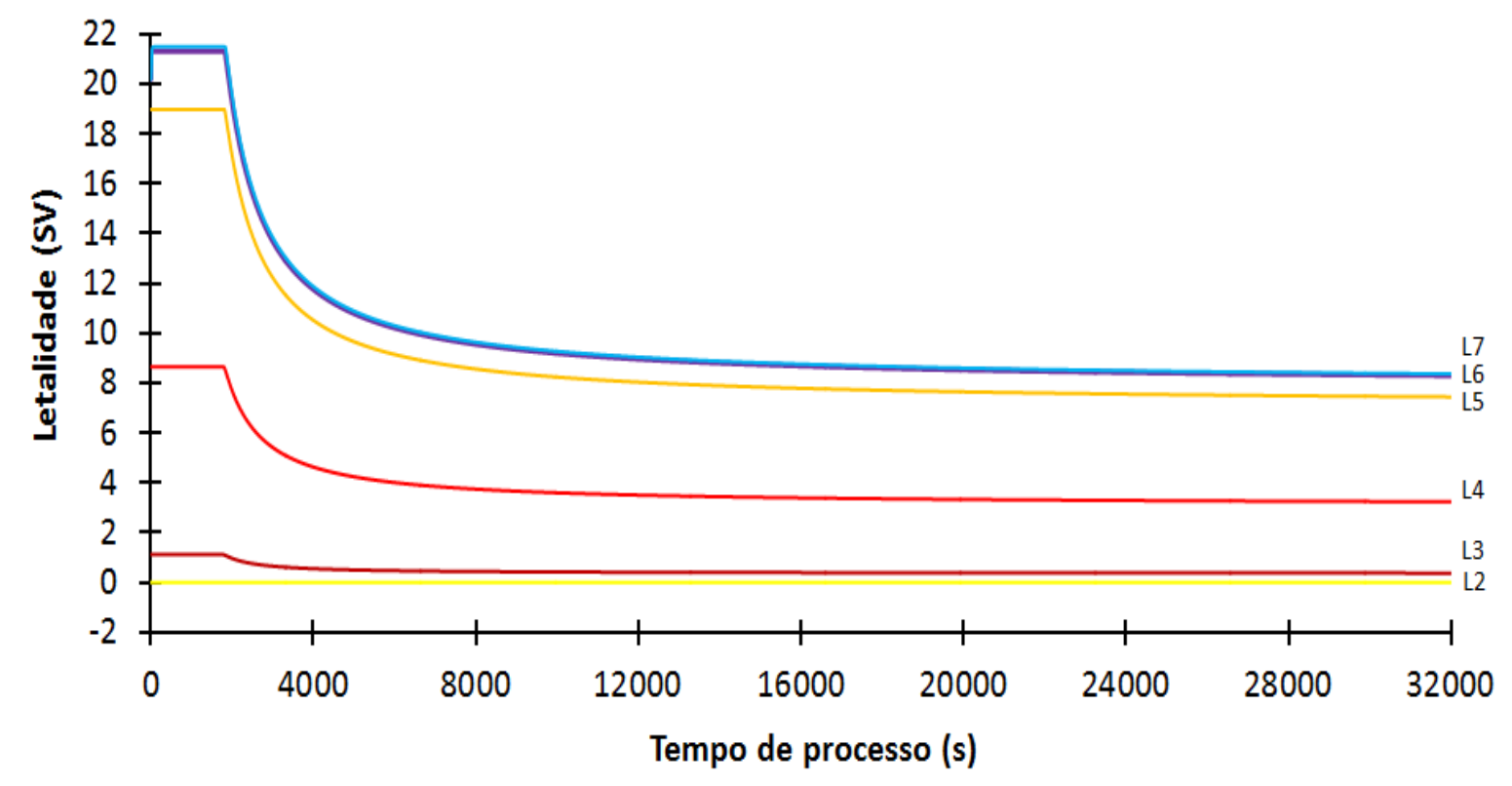

Nota-se que o grau de destruição microbiana vai diminuindo ao longo do processo. Isso ocorre porque a temperatura do leite, em todas as seções, também vai decaindo devido à incrustação do aquecimento e dos tubos. Por exemplo, em L4 (entrada do tubo de retenção) a letalidade (SV) no início do processo, instante $t=0 \mathrm{~s}$, é igual a 8,6. Já ao final do mesmo, no instante $t=32000 \mathrm{~s}$, é equivalente a 3,2. Isto representa uma queda de $S V=5$, considerando os efeitos da incrustação e da perda de calor para o ambiente. Contudo, da seção anterior, já se sabe que a queda de temperatura considerando apenas perda de calor para o ambiente é igual $1,2{ }^{\circ} \mathrm{C}$. Pelas Figura 6.28 e 6.29 a queda de temperatura do leite foi de $2,1^{\circ} \mathrm{C}$. Portanto, temse uma diminuição na temperatura do produto devido ao fenômeno da incrustação igual a $0,9^{\circ} \mathrm{C}$, da entrada ao final do tubo de retenção.

Esse fato é indesejável, pois, além de causar perda de controle do processo e formação de biofilmes microbiológicos, pode levar a redução significativa na destruição microbiana, favorecendo a contaminação do produto final. Por exemplo, a letalidade $(S V)$ da $C$. burnetti, ao tratamento térmico, na saída do processo, no instante $t=0 \mathrm{~s}$, era igual a 21,5 . Já no instante $t=32000 \mathrm{~s}$, estava em 8,4 .

Geralmente, as indústrias lácteas brasileiras de grande porte fazem 0 acompanhamento da incrustação do pasteurizador de modo indireto. Ou seja, controlam a diferença de temperatura entre a saída do leite no tubo de retenção e 
entrada de água na seção de aquecimento, pois como o sistema é composto por um controlador PID, a temperatura do leite na saída da retenção se manterá constante devido ao fornecimento de energia ao processo, causando maiores custos industriais e sobrecarga do sistema de vapor (BON et al., 2010; MÜLLER-STEINHAGEN; 2011).

A distribuição da concentração da bactéria $C$. burnetii $(\mathrm{UFC} / \mathrm{mL})$ em relação ao tempo e ao espaço discretizado e adimensionalizado $(\eta)$, ao longo do processo, no cala 11 da seção de aquecimento, é visto na Figura 6.32.

Figura 6.32 - Distribuição da concentração microbiana $(\mathrm{UFC} / \mathrm{mL})$ da C. burnetii ao longo tempo e do espaço adimensionalizado, no canal 11 da seção de aquecimento, durante a pasteurização de leite sujeito à incrustação.

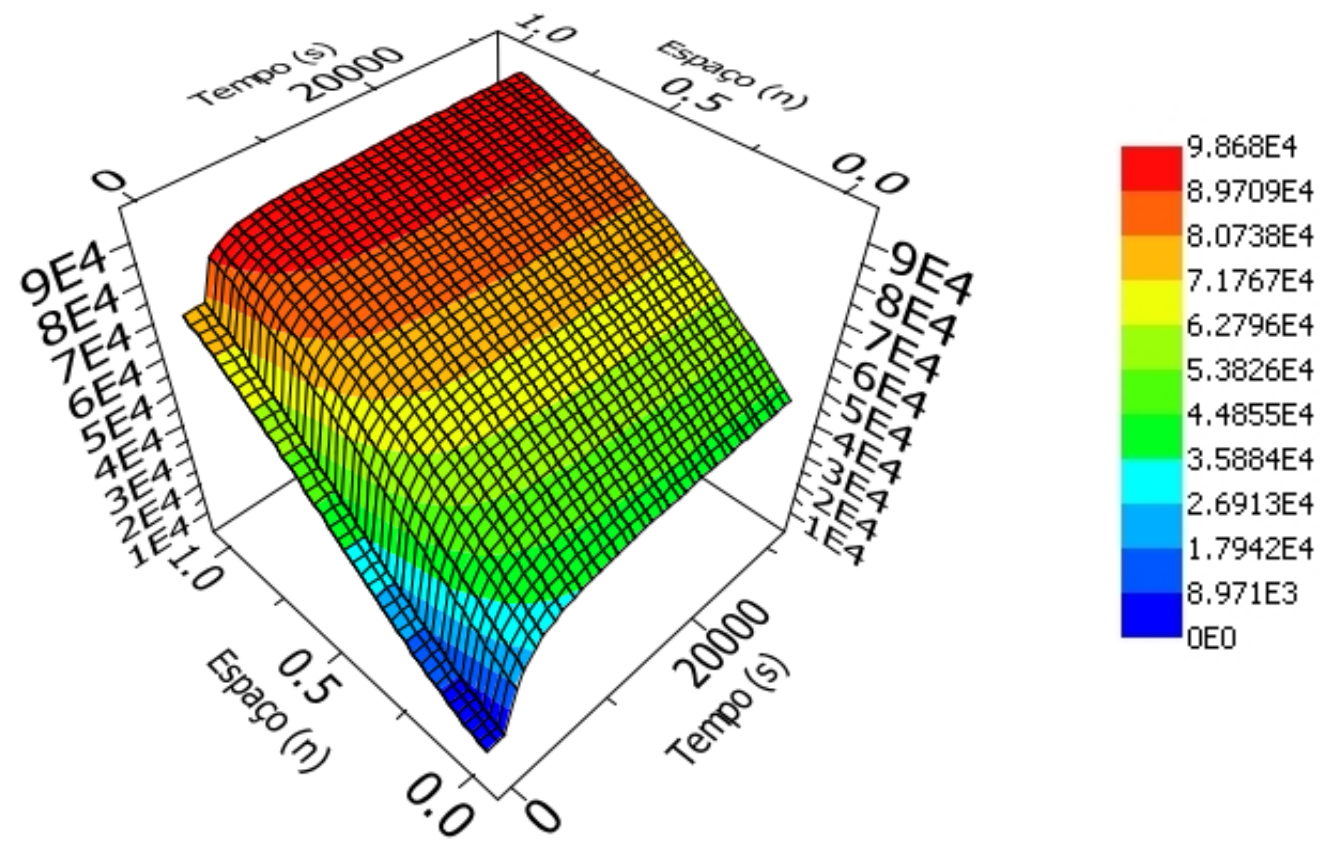

Em relação ao tempo, é possível observar que a taxa de redução na concentração microbiana da bactéria-alvo, devido ao tratamento térmico, aumenta ao longo do tempo (entre os instantes $t=0 \mathrm{~s}$ e $t=1200 \mathrm{~s}$ ) em decorrência do fenômeno da incrustação do leite, que também aumenta com o tempo, até manter-se aproximadamente constante (estado estacionário). Além disso, em termos espaciais (eixo Espaço), como visto anteriormente, a queda na taxa de redução na concentração celular é máxima quando $\eta=0$, isto é, ao final do canal 11 , onde a temperatura do produto é mais alta, e mínima quando $\eta=1$, onde ela é máxima dentro do mesmo canal. 
Em termos computacionais, o tempo total de simulação do processo (pasteurização do leite) foi de 32400 s (9 horas) e o tempo real gasto devido ao esforço computacional (processamento dos modelos no computador) foi de $110 \mathrm{~s}$. Já para o caso de pasteurização sem incrustação, itens anteriores, a simulação (pasteurização) durou $750 \mathrm{~s}$ e o esforço computacional foi igual a $16 \mathrm{~s}$, para o caso de partida do equipamento, por exemplo. O esforço computacional foi maior para a simulação sujeita à incrustação devido à inclusão de novos termos no modelo. Isto é, novos sistemas de equações eram calculados pelo gPROMS uma vez que o número de variáveis aumentou.

\subsubsection{Validação do Processo Sujeito à Incrustação}

Na sequência são mostrados os resultados dos ensaios experimentas, de ajuste do modelo empírico relativo à incrustação da solução de proteína láctea ( $\beta$ lactoglobulina) nas placas do trocador de calor na seção de aquecimento, e a sua validação frente aos dados simulados, após o ajuste dos parâmetros do modelo (experimento descrito na seção 5.6).

Sabe-se que a incrustação sobre a superfície de troca térmica das placas reduz o coeficiente global de troca térmica devido ao aumento da espessura da parede entre o fluido e a utilidade de aquecimento. Por outro lado, a formação destes materiais incrustados nas placas, acabam diminuindo a área de escoamento do fluido, o que causa aumento da velocidade do mesmo e promove diminuição da incrustação devido à maior força de cisalhamento. Como consequência, há um aumento no coeficiente de calor convectivo, o que provoca o aumento do coeficiente global de troca térmica (BOUVIER et al., 2014; GUTIERREZ, 2013).

Nesse sentido, como exemplo do fenômeno da incrustação, na Figura 6.33 são mostradas as fotografias das placas de número 8 e 9 da seção de aquecimento do trocador de calor, após o teste 2, com material úmido logo após o ensaio, com as respectivas identificações dos números e lados das placas bem como as suas gaxetas.

Pelas fotografias da imagem, é observada a formação de depósitos irregulares sobre a superfície das placas bem como a formação de canais preferenciais. Percebese que boa parte das placas não está incrustada, o que corrobora para a premissa de 
que não é toda a área de troca térmica das placas que deve ser levada em conta no cálculo teórico de massa depositada (equação 5.15), como discutido anteriormente.

Figura 6.33 - Placas 8 e 9 da seção de aquecimento do PHE do pasteurizador logo após o processamento da solução proteica.

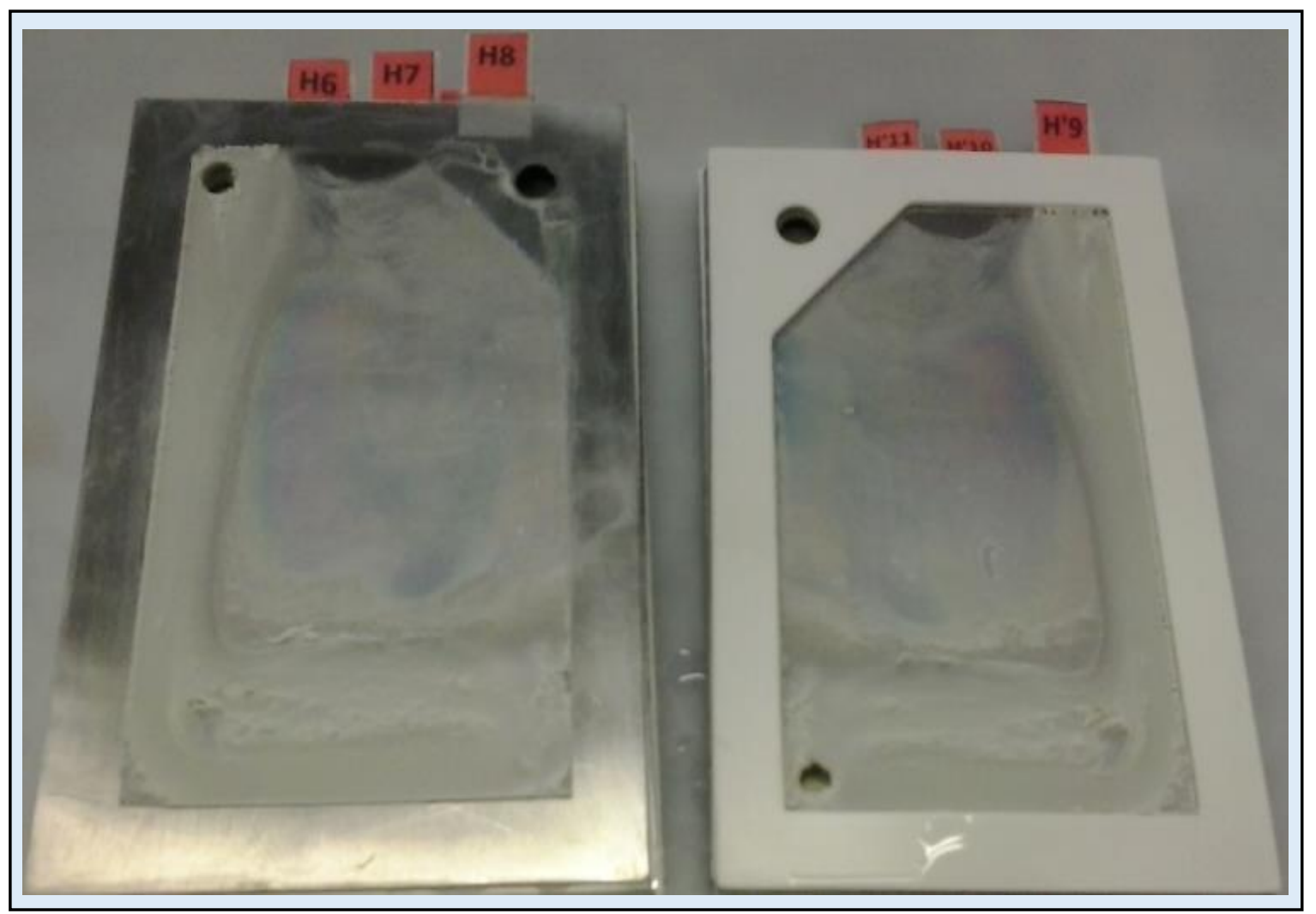

Fonte: elaboração do autor (2016).

Em um estudo de investigação da influência de diferentes superfícies de troca térmica sob a incrustação do leite, Boxler et al. (2012) conduziram experimentos com solução de WPI em duas temperaturas diferentes $\left(80^{\circ} \mathrm{C}\right.$ e $\left.120^{\circ} \mathrm{C}\right)$, em um vaso fechado, com aquisição online de temperatura ao longo do tempo, por 5,8 horas. Os resultados mostraram que a incrustação também varia com a composição química da superfície de contato. Além disso, microscopia eletrônica de varredura foi realizada, sendo mostrada a diferença molecular entre o material incrustado com e sem cálcio. Foi constatado que a ação do fosfato de cálcio catalisa o processo de deposição nas paredes do equipamento mediante a reação química dos componentes do leite, estando isso de acordo com o trabalho de Jeurnink e De Kruif (1995).

Os resultados experimentais de quantidade de material seco depositado nas placas do PHE de aquecimento, após o teste 2, são fornecidos na Figura 6.34. 
Figura 6.34 - Quantidade de material seco depositado nas placas da seção de aquecimento após ensaio experimental.

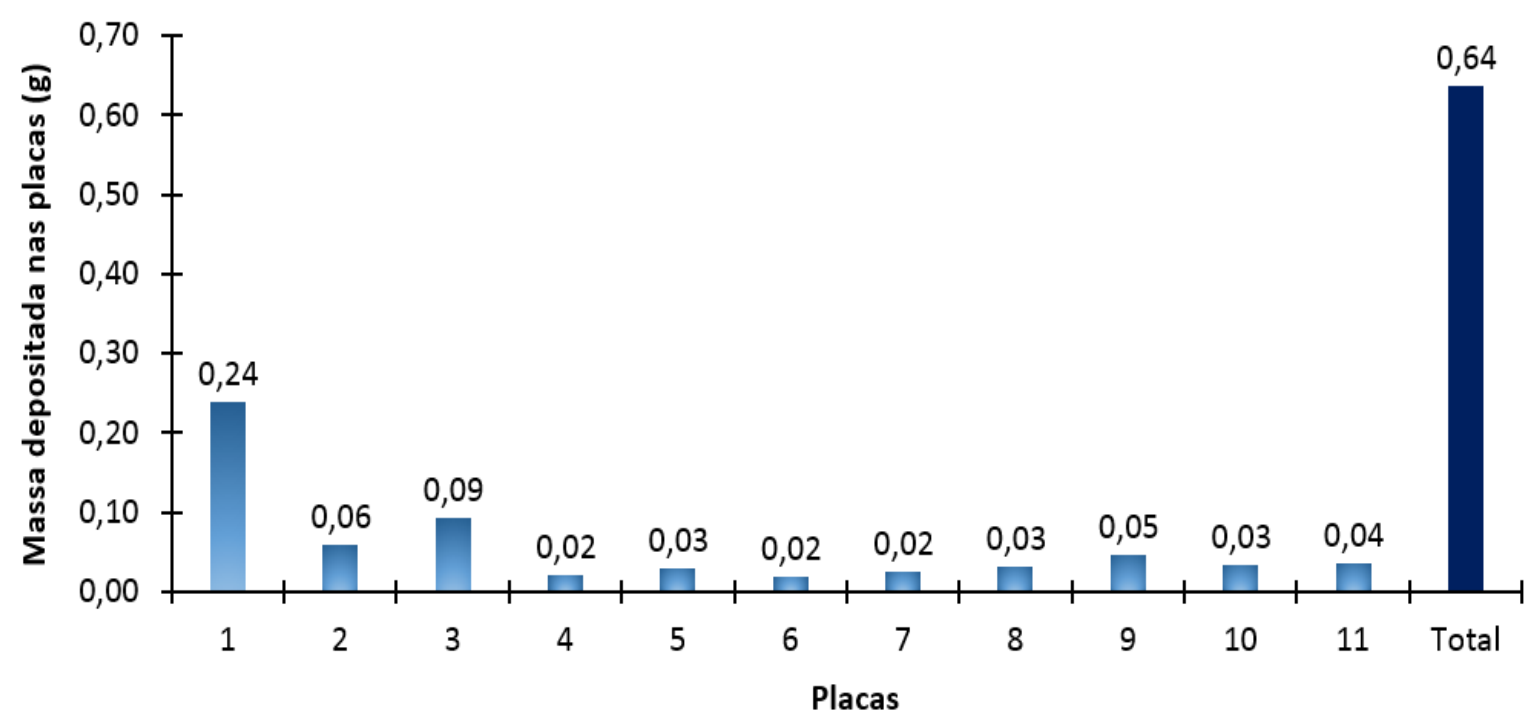

A massa total depositada nas 11 placas do PHE de aquecimento ao final do ensaio foi igual a 0,64 g, sendo que cada placa apresentou quantidade variada.

Georgiadis e Macchietto (2000), obtiveram 9,1 g de material depositado em 4 placas, quando trataram termicamente leite bovino. De Bonis e Ruocco (2009), em um estudo de modelagem e simulação da pasteurização de leite, em um único canal de um PHE, através da técnica de CFD, mostraram que quando o número de Reynolds foi igual a 1700, o valor da massa aderida na placa foi de $11,5 \mathrm{~g}$, e que quando $R e=$ 2700 e $R e=3700$, os valores foram equivalentes a $2,4 \mathrm{~g}$ e 0,39 g, respectivamente, considerando tempo de processo igual a 12000 segundos. Isso ilustra que, quanto maior o número de $R e$, menor será a quantidade de material incrustado nas placas devido à maior taxa de cisalhamento na superfície de aquecimento, a qual acaba por raspar a superfície incrustante (MÜLLER-STEINHAGEN, 201a).

Sabe-se que a desnaturação da $\beta$-lactoglobulina (maior fração do WPI e WPC) inicia-se a $70{ }^{\circ} \mathrm{C}$ (ERABIT et al., 2014; FRYER, BELMAR-BEINY, 1991), sendo a fração proteica mais abundante e uma das mais termosensíveis (LEl et al., 2011; SANTOS et al., 2011b; VISSER, JEURNINK, 1997). Além disso, como, no instante $t=$ 0 s, a solução proteica entrou a $67^{\circ} \mathrm{C}$ no canal 1 (placa 1) e saiu do mesmo canal, no mesmo instante, a $71^{\circ} \mathrm{C}$ e também como a temperatura de saída da solução no canal 5 (placa 3) é igual a $82^{\circ} \mathrm{C}$, então, isso pode-se justificar o porquê das placas 1,2 e 3, na média, apresentaram os maiores valores de massa aderida quando se comparadas 
às outras placas do PHE de aquecimento (Figura 6.34). Portanto, uma vez que a maioria das proteínas se desnaturam - como consequência se depositam na parede de troca térmica -, logo nos primeiros canais (placas) do PHE, a quantidade de proteínas disponíveis para incrustarem as placas subsequentes é menor já que o volume de solução a tratar foi limitado.

A comparação entre o valor final depositado nas placas para os casos laboratoriais e simulados, bem como a curva de deposição teórica na superfície de troca térmica, ao longo do processo, é mostrada na Figura 6.35.

Figura 6.35 - Comparação entre os valores experimentais (teste 2) e os teóricos para massa total depositada nas placas da seção de aquecimento do equipamento.

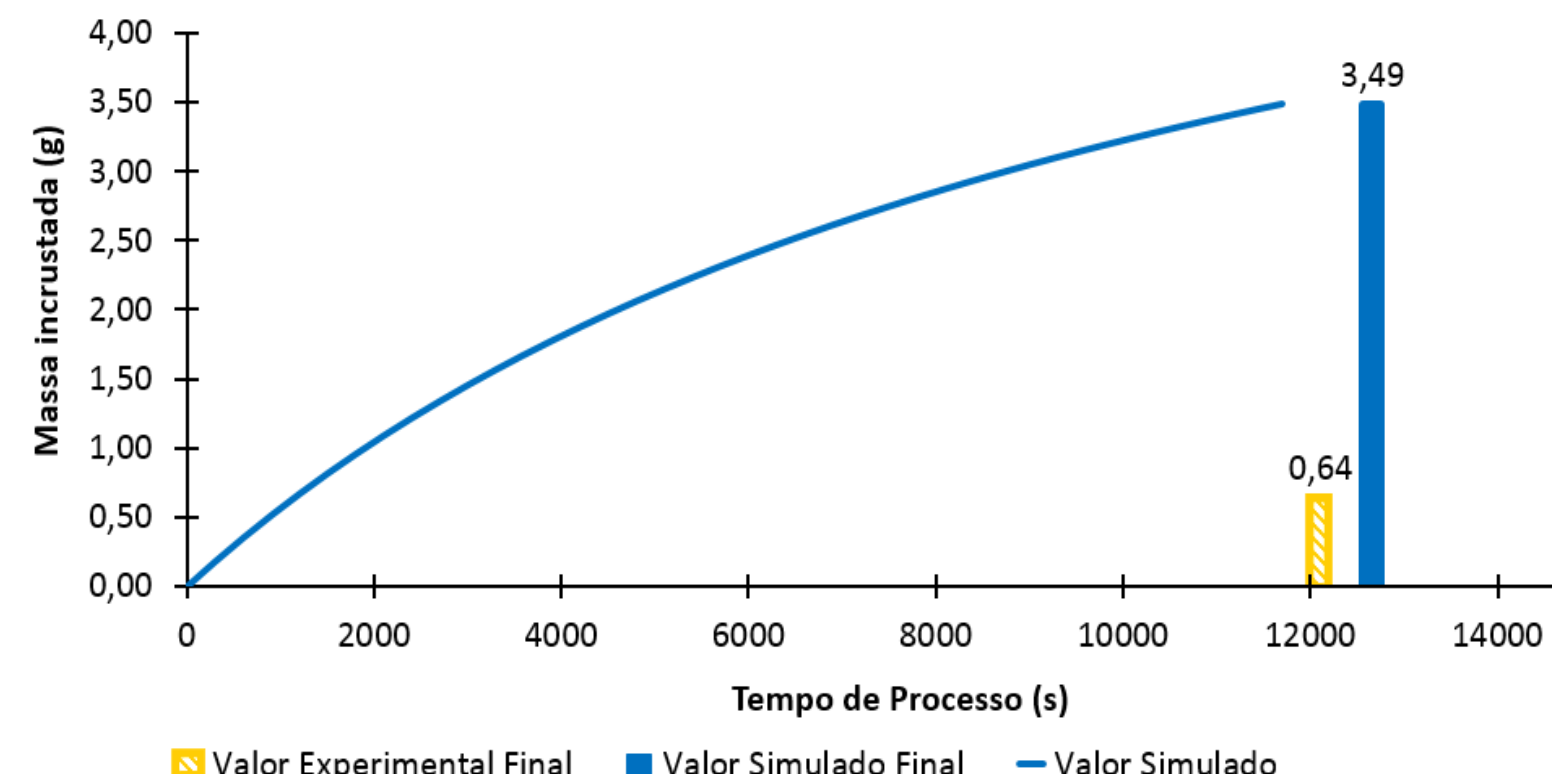

O valor final da massa depositada em toda a seção de aquecimento entre o teste 2 e a sua simulação é diferente. Um dos motivos que justifique essa diferença pode ser devido a consideração de que $100 \%$ da área de troca térmica das placas da seção de aquecimento esteja incrustada com material durante o cálculo teórico da massa depositada, como feito na equação 5.15. Por exemplo, se for considerado que apenas 19 \% da área total de transferência de calor (as placas) esteja com material aderido, ter-se-á 0,649 g de massa depositada ao final do processo para dados teóricos. Então, se na equação 5.15, para o cálculo teórico da massa depositada nas placas, for considerado o valor exato em porcentagem (\%) da área de fato incrustada, provavelmente o resultado calculado será exatamente igual ao experimental. 
Segundo Gutierrez (2013), sabe-se que, durante o escoamento do produto nas placas do PHE, são formados canais preferenciais de escoamento da solução, causando uma heterogênea deposição de material nas placas, como obtido neste trabalho de acordo com a Figura 6.33. Outro motivo que afeta a exatidão do resultado simulado frente ao experimental, para a massa depositada nas placas, foi devido ao uso da consideração da condutividade térmica e da densidade do material depositado para o leite bovino, de acordo com Georgiadis e Macchietto (2000), e não os valores reais desta solução proteica.

Jun e Puri (2006) desenvolveram um modelo 2D para representar a incrustação do leite durante o seu tratamento térmico em PHE, considerando dois tratamentos, 12 canais e 20 canais. Foi realizada a modelagem fenomenológica com base em balanços de energia e material para a proteína reacional ( $\beta$-lactoglobulina). Os autores compararam os seus resultados simulados com os resultados laboratoriais de outro autor e obtiveram resultados satisfatórios, com 32,75 g de material incrustado ao final de 24000 s de processo. Também foi mostrado que, para uma vazão de leite de 0,135 $\mathrm{m} / \mathrm{s}$, obtém-se $1,1 \mathrm{~g}$ de massa depositada no equipamento. Ainda sobre o mesmo trabalho, para vazões menores, maior foi a quantidade de depósito encontrado e menor a queda no coeficiente global de troca térmica.

Gutierrez (2015) conduziu um trabalho para investigar o comportamento das principais proteínas lácteas, $\beta$-lactoglobulina e caseína, assim como o estudo experimental da influência dos parâmetros e das condições de operação do processo, em relação à formação da incrustação do leite nas placas do pasteurizador. Foram realizados ensaios experimentais utilizando soluções de proteína WPI (Proteína isolada do soro) e caseína (caseinato de cálcio) em concentrações parecidas as encontradas no leite integral, com e sem adição de cálcio. Os resultados comprovaram que, mesmo utilizando WPI em dois ensaios idênticos, a queda na transferência de calor, devido ao material depositado nas placas do pasteurizador, é diferente entre os dois testes. Isso só confirma a premissa de que as características intrínsecas da matéria-prima láctea são tão complexas quanto o próprio fenômeno de incrustação. Também foi mostrado que quanto maior a temperatura do processo e maior o teor de cálcio da solução láctea, maior será a quantidade de material depositado nas placas, e que ambas as proteínas favorecem o fenômeno de queda térmica devido à incrustação. 
Os resultados antes e após (após os ensaios laboratoriais, teste 2) o ajuste de parâmetros do modelo empírico da incrustação da solução, no PHE de aquecimento, são mostrados na Tabela 6.3.

Tabela 6.3 - Parâmetros do modelo empírico de incrustação antes e após o ajuste.

\begin{tabular}{cccc}
\hline Parâmetro & Antes & Depois & Unidade \\
\hline$t_{f o}$ & 1.800 & 109 & $\mathrm{~s}$ \\
$\alpha_{f}$ & 1.380 & 1.084 & $1 / \mathrm{s}$ \\
$R_{\max }$ & $2,8 \times 10^{-4}$ & $2,4 \times 10^{-4}$ & $\mathrm{~K} \cdot \mathrm{m}^{2} / \mathrm{W}$ \\
$U$ (limpo) & 1.061 & 1.061 & $\mathrm{~W} / \mathrm{m}^{2} . \mathrm{K}$ \\
\hline
\end{tabular}

O tempo de indução para ocorrência da incrustação do produto nas placas do equipamento foi o parâmetro com maior variação após o ajuste. Por ser muito pequeno, foi desprezado na simulação. Contudo, há trabalhos em que ele foi mais significativo, sendo: 30 minutos para Bennet (2007), 1 hora para Augustin, Geddert e Scholl (2007) e 42 minutos para Georgiadis e Macchietto (2000).

De acordo com Belmar-Beiny et al. (1993), o tempo de indução em trocadores tubulares (de 0 a 60 minutos) é maior do que em trocadores a placa, sendo esse período, para os PHEs, próximo a zero (PATERSON, FRYER, 1988), em decorrência de sua geometria e por conterem áreas de baixo cisalhamento (DE JONG, 2008).

Boxler et al. (2012), em um estudo de avaliação da influência do tipo de material de troca térmica, em processo de pasteurização em batelada, usando solução simulada próxima ao leite bovino (WPI + água + fosfato de cálcio), encontraram um período de indução de pouco mais de 2 horas para placas de superfície térmica de aço inoxidável e de 15 minutos para uma liga metálica SICO® (a-C:H:Si:O). Os autores concluíram que o tempo de indução da incrustação da solução láctea depende do tipo de superfície de aquecimento devido às suas propriedades físicas, como rugosidade, e químicas, energia livre do material de contato, sendo que, a deposição do produto nas paredes do equipamento, entre outros fatores, depende da reação química entre o fluido e superfície de troca térmica, como, por exemplo, interações intermoleculares, eletrostáticas e de van-der-Waals.

Segundo Na e Webb (2003), é possível utilizar um modelo matemático de base fenomenológica para determinar a taxa de formação da área de superfície de 
nucleação da indução da incrustação, a qual indica que a indução do processo necessita superar a barreira de energia livre de Gibbs.

Resumidamente, o tempo de indução da incrustação depende de vários fatores, tais como: tipo de equipamento, tipo e material de placa, característica do produto, variáveis e condições operacionais, entre outros (AUGUSTIN et al., 2007; BELMARBEINY et al., 1993; BENNET, 2007; BOXLER et al., 2012).

Pela Figura 6.36, tem-se a comparação dos resultados simulados, após o ajuste do modelo, e laboratoriais (teste 2) dos perfis de temperatura, ao longo do tempo de processo em estado estacionário, das utilidades de aquecimento e resfriamento, na entrada e na saída da seção de aquecimento do pasteurizador.

Figura 6.36 - Perfis de temperatura simulada (curvas) e experimental (pontos) das utilidades de aquecimento e resfriamento na seção de aquecimento do equipamento.

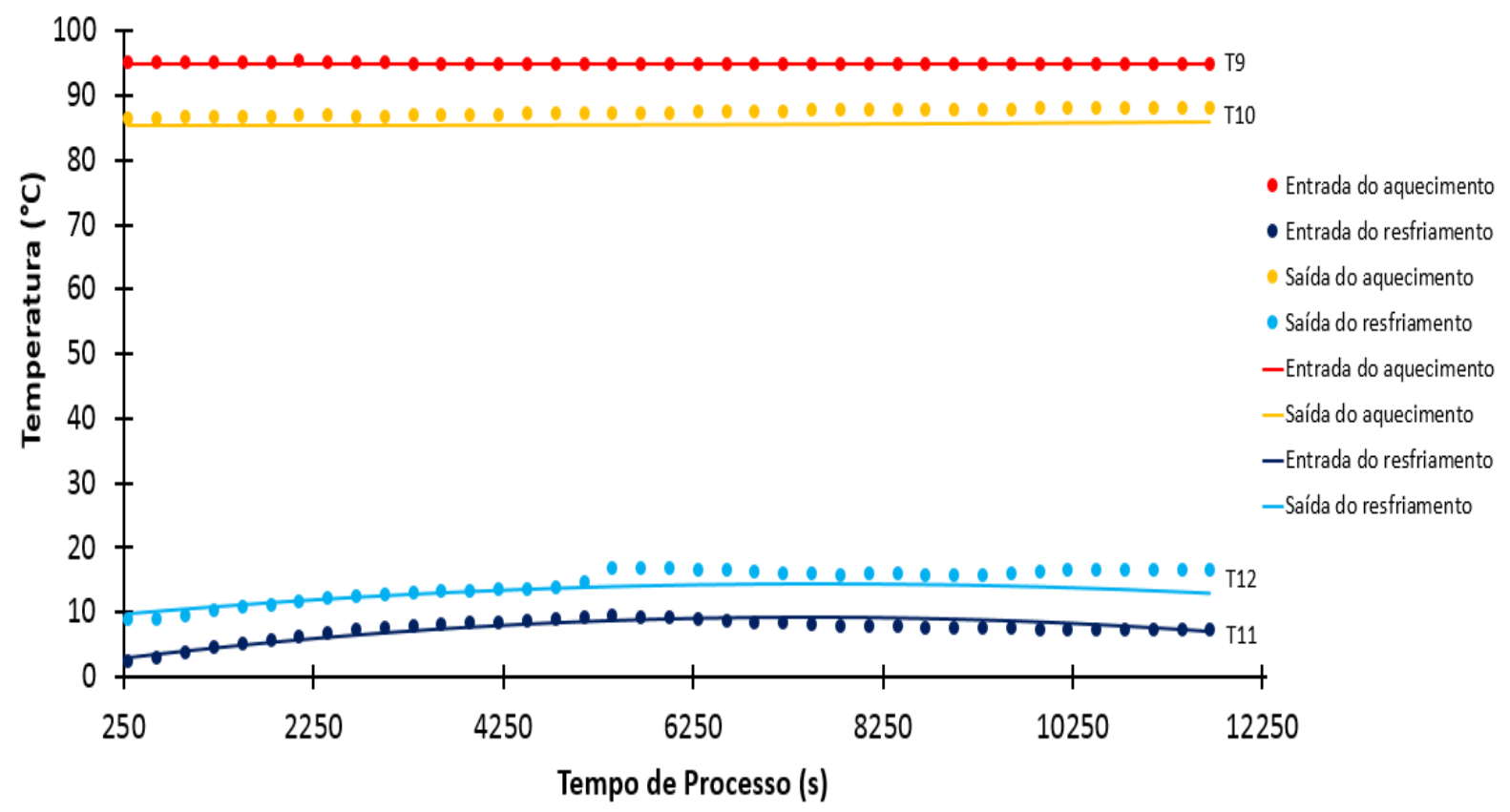

De modo geral, todos os pontos experimentais estão satisfatoriamente próximos aos valores teóricos. Embora haja pequenas variações nos perfis de temperatura da água na entrada e na saída do resfriamento e na saída da água de aquecimento, o processo pode ser considerado pseudo-estacionário.

Especificamente sobre a seção de aquecimento, os resultados experimentais e simulados de temperatura de entrada da água são iguais, sendo isso algo esperado, uma vez que a mesma foi definida no sistema de aquecimento do pasteurizador, o qual possui controle PID. Então, percebe-se que não houve alteração significativa na 
temperatura de aquecimento da água, o que comprova o atingimento do estado estacionário do processo. Em relação à saída do aquecimento (T10), os valores teóricos e práticos estão bastante próximos, mas não iguais. Nota-se que em ambos os casos houve queda no valor da temperatura da água de saída da seção de aquecimento, sendo esse comportamento esperado para um sistema em malha aberta. Por exemplo, a temperatura experimental inicial da água no início do processo é igual a $91,3^{\circ} \mathrm{C}$ e a simulada é equivalente a $90,9{ }^{\circ} \mathrm{C}$. Já no final, elas são correspondentes a $91,0^{\circ} \mathrm{C}$ e a $90,2{ }^{\circ} \mathrm{C}$, respectivamente, considerando um período de processo de 3,3 horas. Essa queda de temperatura ocorre devido à perda de eficiência de transferência de calor da água para o produto, ocasionada pelo efeito da incrustação da solução proteica nas placas do equipamento. Como já mostrado anteriormente, isso é um efeito indesejável, uma vez que resulta na redução de destruição térmica microbiana $(S V)$. Logo, pelos dados simulados para este caso, nas mesmas temperaturas, ter-se-á uma redução em $S V$ de 7 em relação ao valor original, ou seja, $6 \%$ de diminuição de letalidade.

Nas indústrias de laticínios, esse tipo de processo é operado em malha fechada, com controladores de temperatura do leite na saída da retenção. Ou seja, conforme a sua temperatura vai diminuindo com o tempo de processo por causa da incrustação, mais vapor é usado para aumentar a temperatura da água de aquecimento do produto na seção de aquecimento, fazendo com o leite mantenha-se na temperatura especificada para garantir a sua correta pasteurização (BYLUND, 1995; DE JONG, 2008).

A respeito dos perfis de temperatura experimentais da água na entrada da seção de resfriamento (T11), é perceptível a sua variação ao longo do tempo e, obviamente, afetando a temperatura de saída (T12). Isso ocorre devido à falta de controlador de temperatura PID, ocorrendo, então, variações naturais. Além disso, é possível observar um "degrau" nos perfis de temperatura por volta do instante $t=4700 \mathrm{~s}$, sendo isso o resultado da recirculação do produto já pasteurizado.

A Figura 6.37, mostra a comparação entre a temperatura teórica, após o ajuste do modelo, e a experimental (teste 2) do produto ao longo do tempo de processo. Novamente, as indicações T1, T2, T3, T4, T5, T6, T7 e T8, que correspondem aos pontos representativos do processo de pasteurização, sendo estes já mostrados e descritos na Figura 4.1 e no item 4.3.1, do capítulo de Modelagem. 
Figura 6.37 - Perfis de temperatura simulada e experimental (teste 2) da solução representativa ao leite na seção de aquecimento do equipamento.

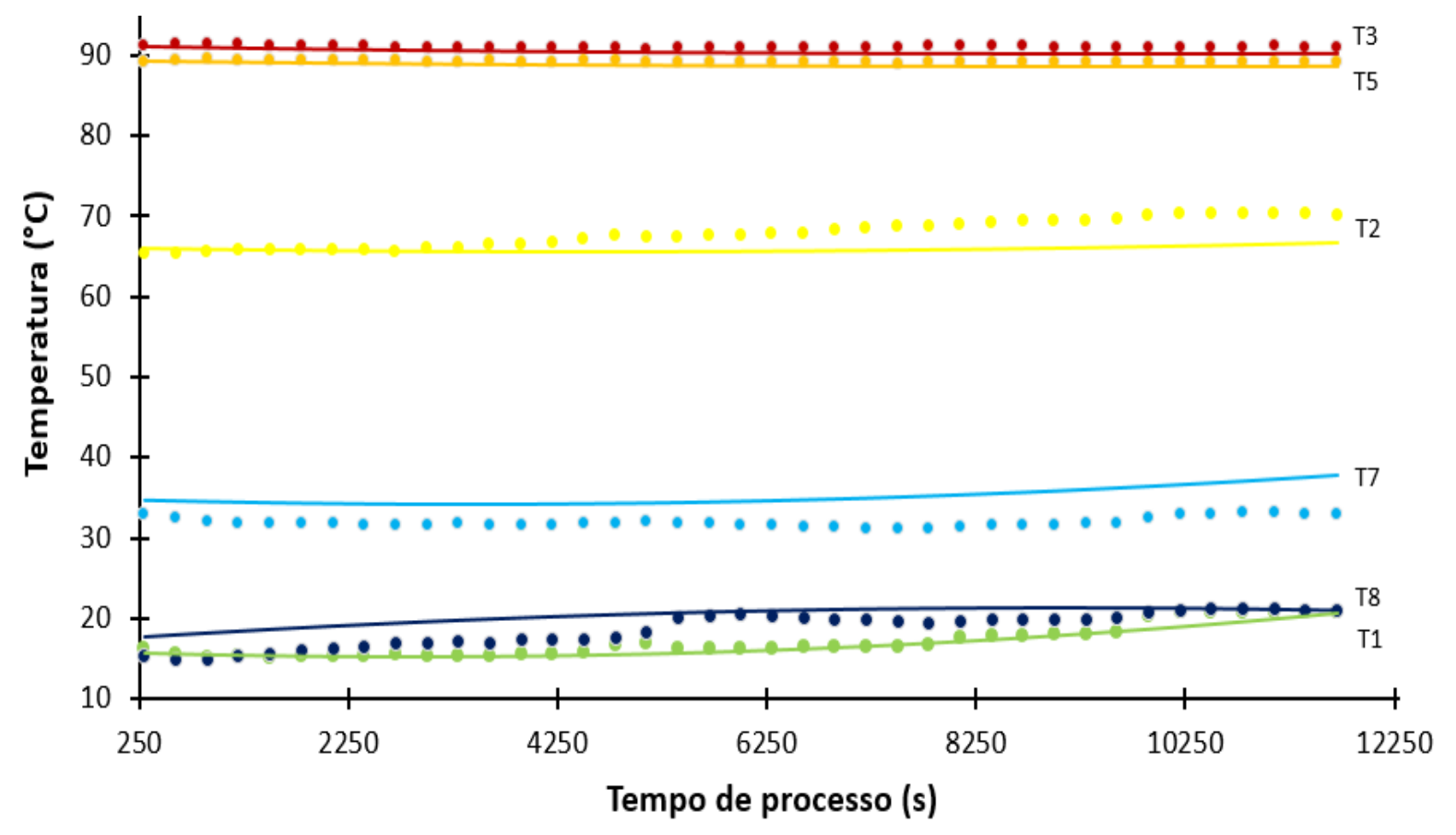

Do mesmo modo que no caso da água, os perfis de temperatura laboratoriais e simulados da solução de proteína de leite ( $\beta$-lactoglobulina) estão plausivelmente similares entre si. Mesmo sujeito às variações suaves, é razoável afirmar que o processo se encontra de fato em estado pseudo-estacionário. Não é considerado puramente estacionário porque há oscilações nos valores de temperatura do produto, ao longo do tempo de processo, em todas as seções do pasteurizador.

As variações de temperatura na entrada do equipamento (linha T1) são progressivas porque o produto foi mantido à temperatura ambiente logo antes da pasteurização. Somado a isso, por volta do instante $t=4700 \mathrm{~s}(1,2$ horas após a partida do processo), a solução começou a ser reprocessada, causando este aumento na temperatura de entrada. Para este caso, na simulação do processo, foi modelada uma função de temperatura por tempo de acordo com os dados experimentais, pela regressão linear em Excel, sendo inserida no gPROMS.

Os perfis de temperatura na saída da seção de aquecimento e na saída do tubo de retenção (T5 e T3), que são mais críticas para o controle do processo, apresentaram excelentes resultados, estando os valores laboratoriais e simulados bastante próximos. Nesse sentido, a partir da Figura 6.38, oriunda da Figura 6.37, 
observa-se esses dois perfis mais de perto entre os instantes $t=250 \mathrm{~s}$ e $t=12250$ $s$, podendo-se notar os efeitos de queda de temperatura em virtude da incrustação.

Figura 6.38 - Perfis de temperatura experimental da solução proteica na saída da seção de aquecimento e do tubo de retenção, respectivamente, durante o teste 2.

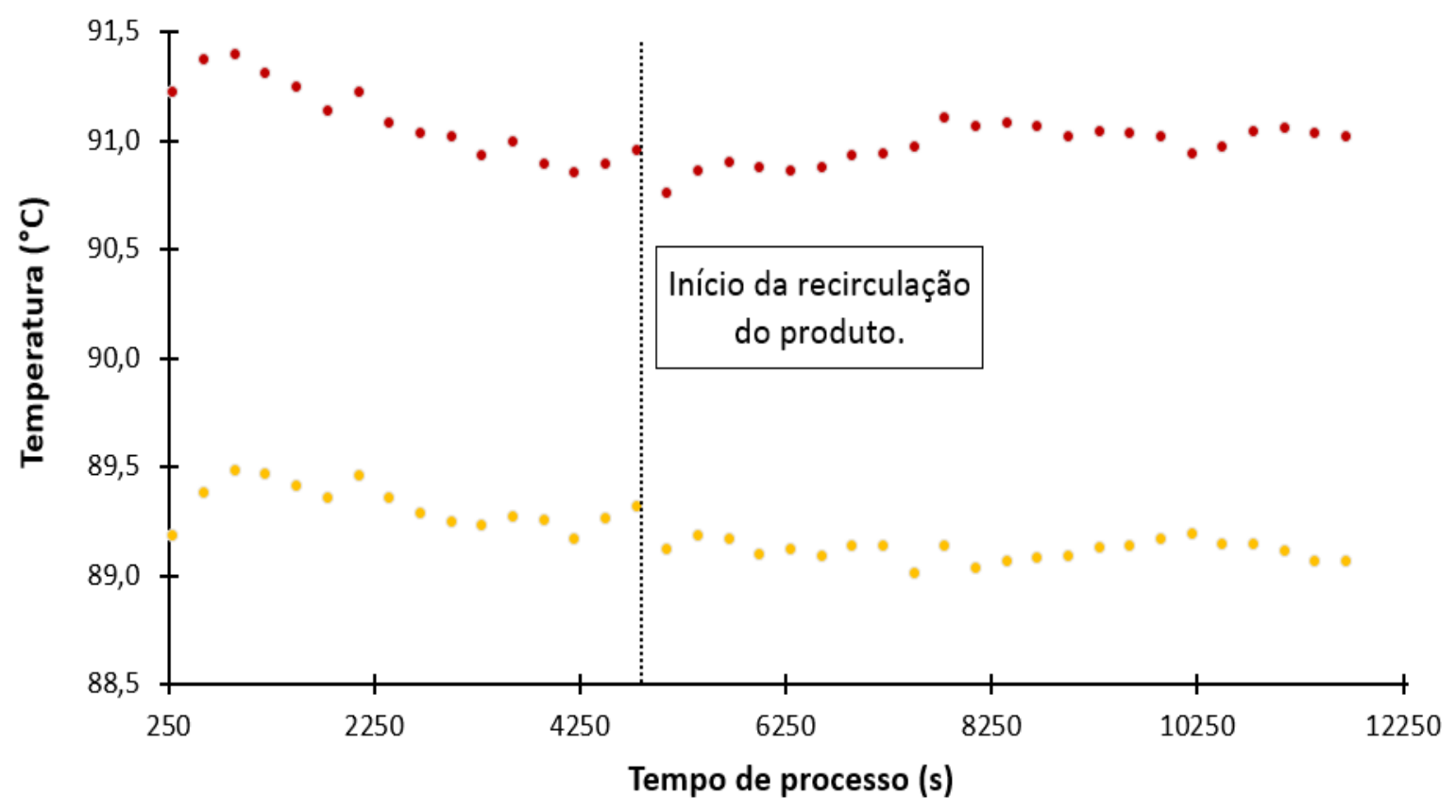

De modo geral, os resultados mostram que a temperatura do produto vai diminuindo em ambos os casos. Na seção de aquecimento (primeira curva), isso ocorre em decorrência do fenômeno da incrustação do produto nas placas do PHE, o que causa menor efetividade de troca térmica entre a solução e a utilidade de aquecimento. Este efeito também é sentido, como consequência, na temperatura do produto na saída do tubo de retenção. Essa diferença entre temperatura inicial e final, na saída da retenção, neste caso, chega quase a $1{ }^{\circ} \mathrm{C}$ e, pelos dados simulados, para esse mesmo desvio, tem-se uma redução na letalidade de $S V=7$, o que representa uma diminuição de $3 \%$ na efetividade da pasteurização da solução proteica.

O que torna o processo pseudo-estacionário é o fato de a temperatura da solução na saída da retenção praticamente não se alterar, embora ela caia sutilmente ao longo do tempo de processo devido à incrustação e à perda de calor ambiente no tubo de retenção. Como consequência, isso resulta num período transitório para o perfil de letalidade do tratamento térmico, como mostrado no item 6.4. 
A Figura 6.39 ilustra o valor calculado da taxa de energia térmica da solução $(\dot{Q})$, em relação ao tempo de processo, com base nos seus perfis de temperatura experimentais (teste 2) e simulados após o ajuste do modelo, apenas na seção de aquecimento.

Figura 6.39 - Comparação entre os valores experimentais (pontos discretos) e os simulados (linha contínua) para taxa de energia térmica da solução no aquecimento.

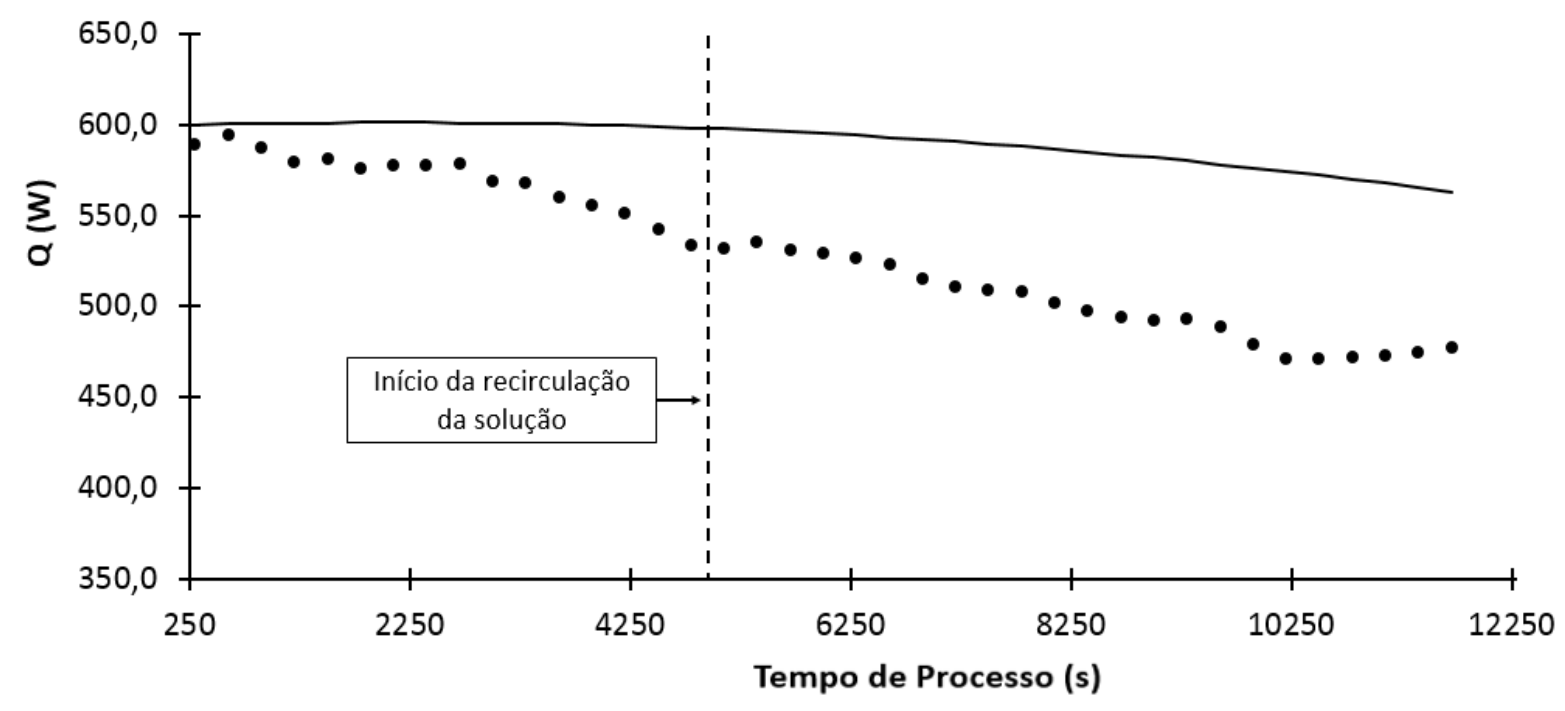

Como efeito da incrustação do produto nas placas do PHE, na seção de aquecimento, tem-se uma queda na taxa de energia térmica da solução proteica $(\dot{Q})$, a qual é oriunda da utilidade de aquecimento. Esse fenômeno é o responsável pela diminuição nos valores de temperatura lidos pelos termopares, com relação ao teste 2, e nos simulados, mostrados anteriormente.

Nota-se pela Figura 6.39 que os resultados experimentais e os simulados estavam similares até $\mathrm{o}$ instante $t=4000 \mathrm{~s}$. Após esse instante, percebe-se que a queda na quantidade de calor experimental é mais acentuada do que para o caso teórico. Uma possível explicação para isso é devido à perda de calor ambiente nas extremidades das placas, a qual foi negligenciada durante a modelagem do processo, pois o principal elemento responsável por esta diferença de resultados é a diferença de temperatura entre a saída e entrada do produto, a qual afeta os valores das propriedades termofísicas do fluido (equação 5.12).

Além disso, por volta do instante $t=4700 \mathrm{~s}$, especificamente para dados experimentais, percebe-se a presença de um degrau nos pontos discretos em decorrência da recirculação do produto já pasteurizado. 
Bennett (2007) processou leite bovino em uma planta piloto composta por trocador de calor a placas, trocador de calor tubular e evaporador, sendo feito o registro da temperatura do produto, com uso de termopares, ao longo do tempo. Também foi avaliada a influência da formação de bolhas na incrustação do produto. Bennett (2007) encontrou perfil de queda na taxa de energia térmica da solução, durante o processo, com duração de 3,5 horas, similar ao encontrado neste trabalho.

Os resultados do teste 2 e de sua respectiva simulação para estudo do comportamento do fator de incrustação $\left(R_{f}\right)$ e do coeficiente global de transferência de calor $\left(U_{t}\right)$, após o ajuste do modelo, para o processo sujeito à incrustação em estado estacionário, podem ser vistos nas Figuras 6.40 e 6.41, respectivamente.

Figura 6.40 - Comparação entre os valores experimentais (pontos discretos) e os simulados (linha contínua) para o fator de incrustação do produto no aquecimento.

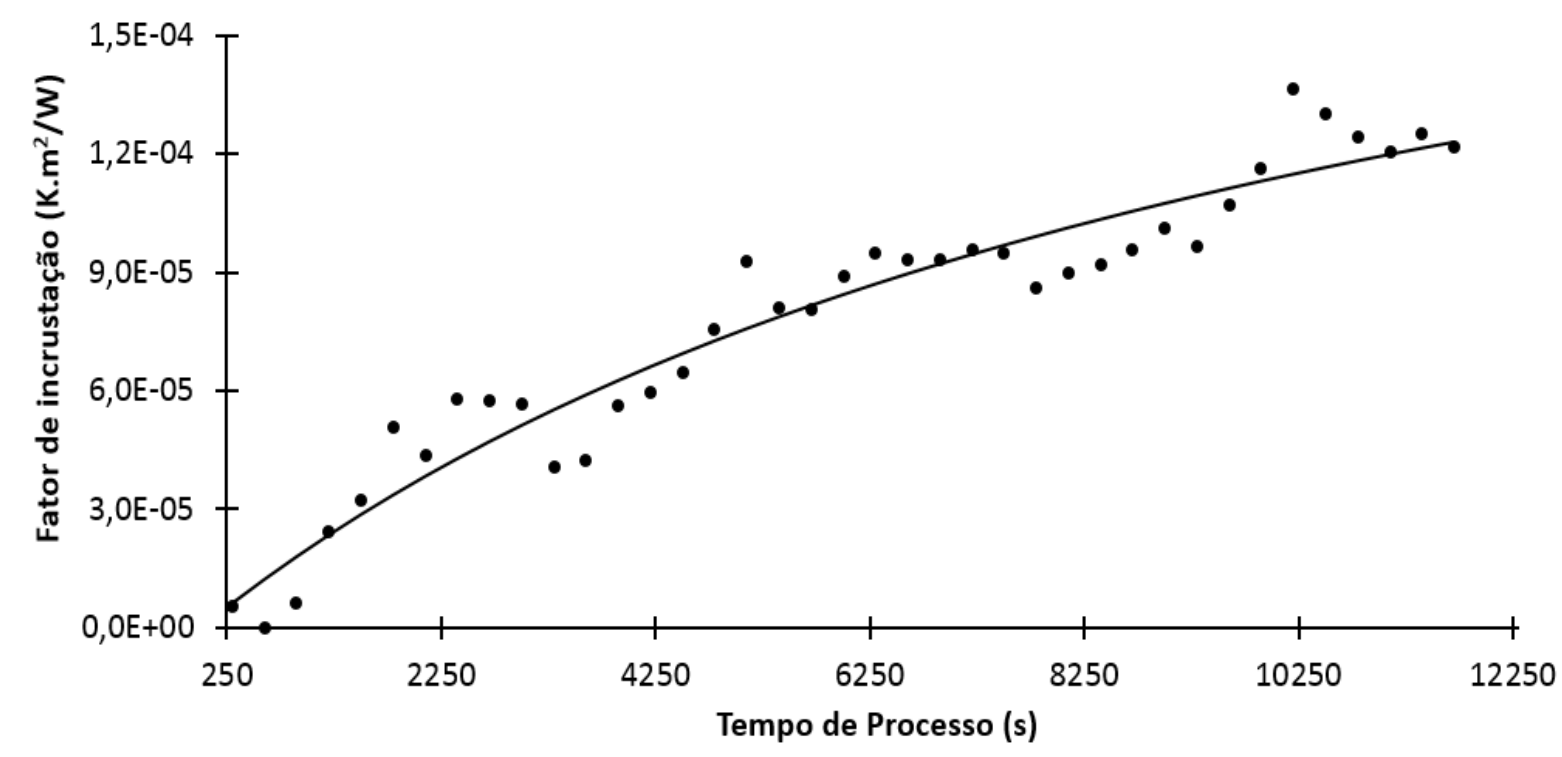

Observa-se que o fator de incrustação aumenta ao longo do tempo de processo, estando isso de acordo com o que já fora observado no item 6.4. Para este caso, o tempo de indução da incrustação foi igual a 109 s, sendo, então, desprezado. Porém, percebe-se que esse fator, ou seja, a incrustação, só se torna de fato significativa a partir do instante $t=1200 \mathrm{~s}$, sendo que, o tempo de indução para o caso da simulação antes do ajusto do modelo, foi igual a $1800 \mathrm{~s}$.

O perfil do fator de incrustação $\left(R_{f}\right)$ deste trabalho (Figura 6.40) está de acordo com os perfis obtidos por Augustin, Geddert e Scholl (2007) para os casos de superfície de aço inox e alumínio, com uso de solução composta por 3,5 \% de WPC. O tempo 
de indução encontrado pelos pesquisadores foi por volta de 1 hora (3600 s). Eles avaliaram o fator de incrustação de solução proteica de WPC em duas concentrações, 3,0 e 3,5 \%, em um vazo fechado sob agitação contínua. A temperatura foi registrada com uso de termopares ao longo do tempo para a quantificação da incrustação do produto. Também foi avaliada a influência de diferentes tipos de superfícies, como aço inoxidável, cobre e alumínio, com ensaios de 24 horas de duração. Os resultados dos autores mostraram que a incrustação é muito mais pronunciada numa concentração de 3,5 \% de WPC e que dentre as três superfícies avaliadas, o aço inoxidável é a que mais favorece a incrustação, sendo também o mais usado na indústria láctea, e de alimentos em geral, seguidamente do alumínio.

Figura 6.41 - Comparação entre os valores experimentais (pontos discretos) e os simulados (linha contínua) para o coeficiente global de transferência de calor na seção de aquecimento entre o produto e a utilidade.

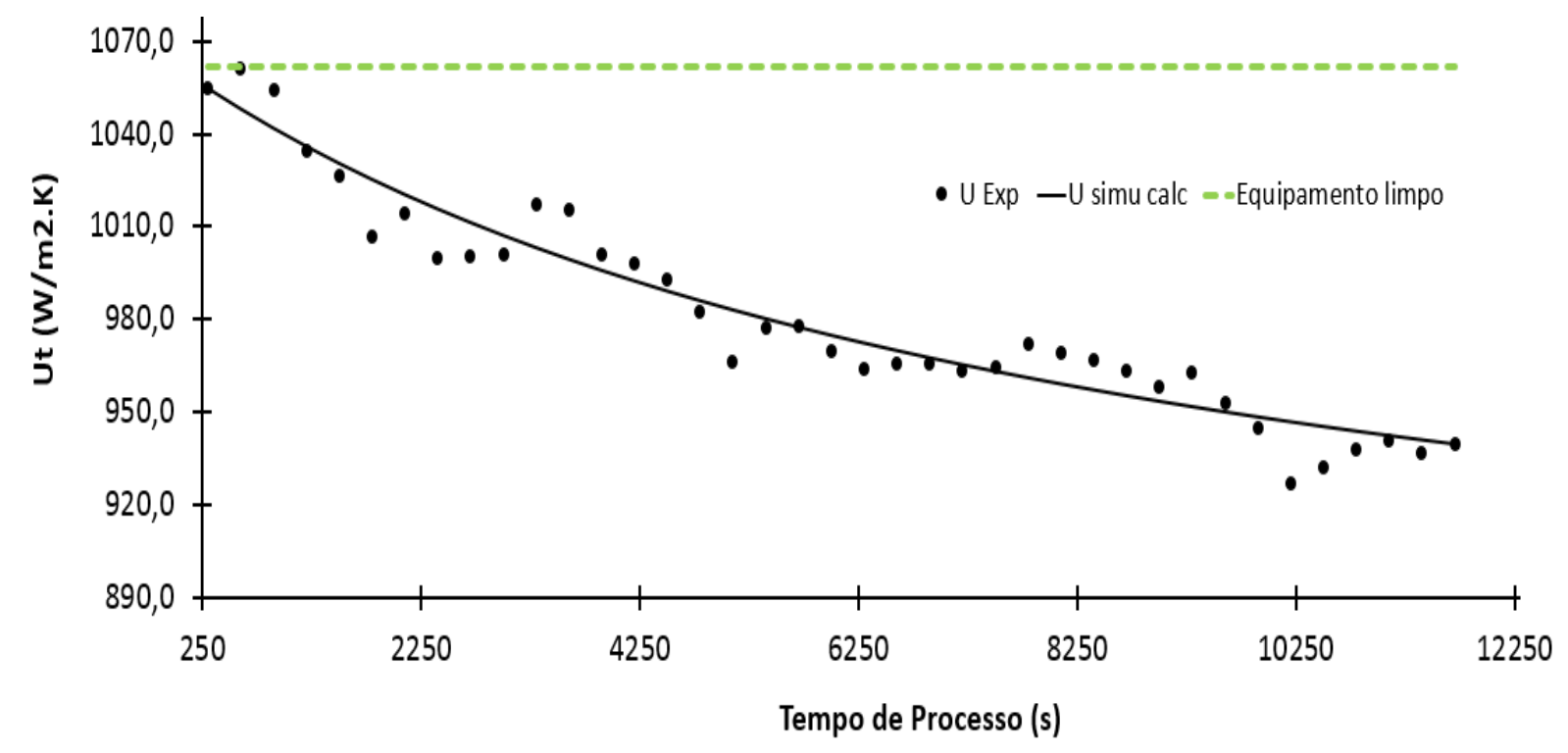

Pela Figura 6.41 nota-se que os resultados teóricos estão razoavelmente de acordo com os resultados práticos, estando o modelo bem representado. Para este caso, houve uma redução de $11,5 \%$ no valor de $U_{t}$, se comparado ao seu valor original (equipamento limpo), isto é, de 1061 para $939 \mathrm{~W} / \mathrm{m}^{2} . \mathrm{K}$, em razão da incrustação.

Em um estudo da pasteurização de leite de coco, Pichitvittayakarn et al. (2006), processaram o produto de $70,0^{\circ} \mathrm{C}$ até $74,5^{\circ} \mathrm{C}$, em três vazões diferentes $(2,4$ e 6 $\mathrm{L} / \mathrm{min}$ ), coletando dados de temperatura ao longo do tempo a fim de avaliar o perfil do 
coeficiente global de transferência de calor. Também compararam dados teóricos com dados experimentais. Os resultados obtidos mostraram que quanto maior a vazão, maior o coeficiente global de transferência de calor inicial e que a taxa de queda do mesmo, devido à incrustação, é menor para vazões maiores. Os perfis encontrados pelos autores, tanto para o fator de incrustação quanto para o coeficiente global de transferência de calor, estão similares aos deste trabalho.

Boxler et al. (2014) em uma investigação de redução do efeito da incrustação em placas chevron, de um PHE convencional, testaram o escoamento pulsátil a fim de aumentar a tensão de cisalhamento e causar remoção do material aderido nas placas. Basicamente, o modelo usado pelos autores para comparação dos resultados experimentais também foi composto pelas equações $4.65,4.66$ e 5.13 . O teste foi conduzido a partir de solução de WPI + $\mathrm{KOH}$ + fosfato de cálcio com aquecimento até $85^{\circ} \mathrm{C}$, com Reynolds igual a 870 nos canais com as placas de aço inoxidável. Os resultados encontrados pelos pesquisadores indicaram que o escoamento pulsátil reduz o valor do fator de incrustação se comparado com o mesmo processo em escoamento contínuo, obtendo valores iguais a $3,8 \times 10^{-5} \mathrm{~m}^{2} . \mathrm{K} / \mathrm{W}$ e $3,0 \times 10^{-5} \mathrm{~m}^{2} . \mathrm{K} / \mathrm{W}$, com e sem pulsação, respectivamente. Além disso, em ambos os casos, o período de indução da incrustação do produto foi aproximadamente nulo (0).

Georgiadis e Macchietto (2000), modelaram, simularam e validaram o processo dinâmico de aquecimento do leite bovino apenas em um trocador de calor a placas, sujeito à incrustação, por 6,7 horas. Foi levando em conta a variação temporal e espacial da temperatura do produto, bem como a concentração de proteína nativa, desnaturada, agregada e depositada, por balanço material. $\mathrm{O}$ trabalho foi conduzido para 3 tipos de passes diferentes e com uma temperatura de entrada do leite a $60^{\circ} \mathrm{C}$, também em gPROMS. Foi obtido como resultado, em um dos arranjos, uma queda de $2,4^{\circ} \mathrm{C}$ na temperatura do produto ao longo do processo devido à incrustação. Embora o coeficiente global de transferência de calor tenha registrado queda ao longo do tratamento térmico, assim como neste trabalho, Georgiadis e Macchietto (2000) obtiveram uma queda foi mais pronunciada.

Pela inspeção das Figuras 6.40 a 6.41, fica claro que há valores maiores e menores (oscilações) para todos os dados experimentais ao longo do tempo de processo. Ou seja, embora os resultados mostrados representem perfis de tendência de uma curva assintótica, há pontos acima e abaixo destas tendências. Um dos motivos para estas variações é que, como a solubilidade do ar no leite diminui durante 
o seu aquecimento (WALSTRA et al., 1999), e se a pressão estiver muito baixa (abaixo da pressão de saturação), bolhas de ar podem ser formadas no leite ou em solução láctea (JEURNINK, 1995). Caso bolhas sejam formadas durante a sua pasteurização, elas irão agir como núcleos favoráveis a formação de incrustação, desde que estas bolhas estejam em contato com a superfície de aquecimento (BENNET, 2007; BURTON, 1968; JEURNINK, 1995; WALSTRA et al., 1999). Então, isso causará heterogeneidade na transferência de calor da utilidade à solução.

Nesse contexto, na Figura 6.42, observa-se o registro de formação de bolhas de ar no tubo de retenção e em suas conexões durante os testes experimentais, as quais são indesejáveis durante o processo.

Figura 6.42 - Formação de bolhas de ar nos tubos e conexões do equipamento durante a pasteurização da solução láctea para a validação experimental.

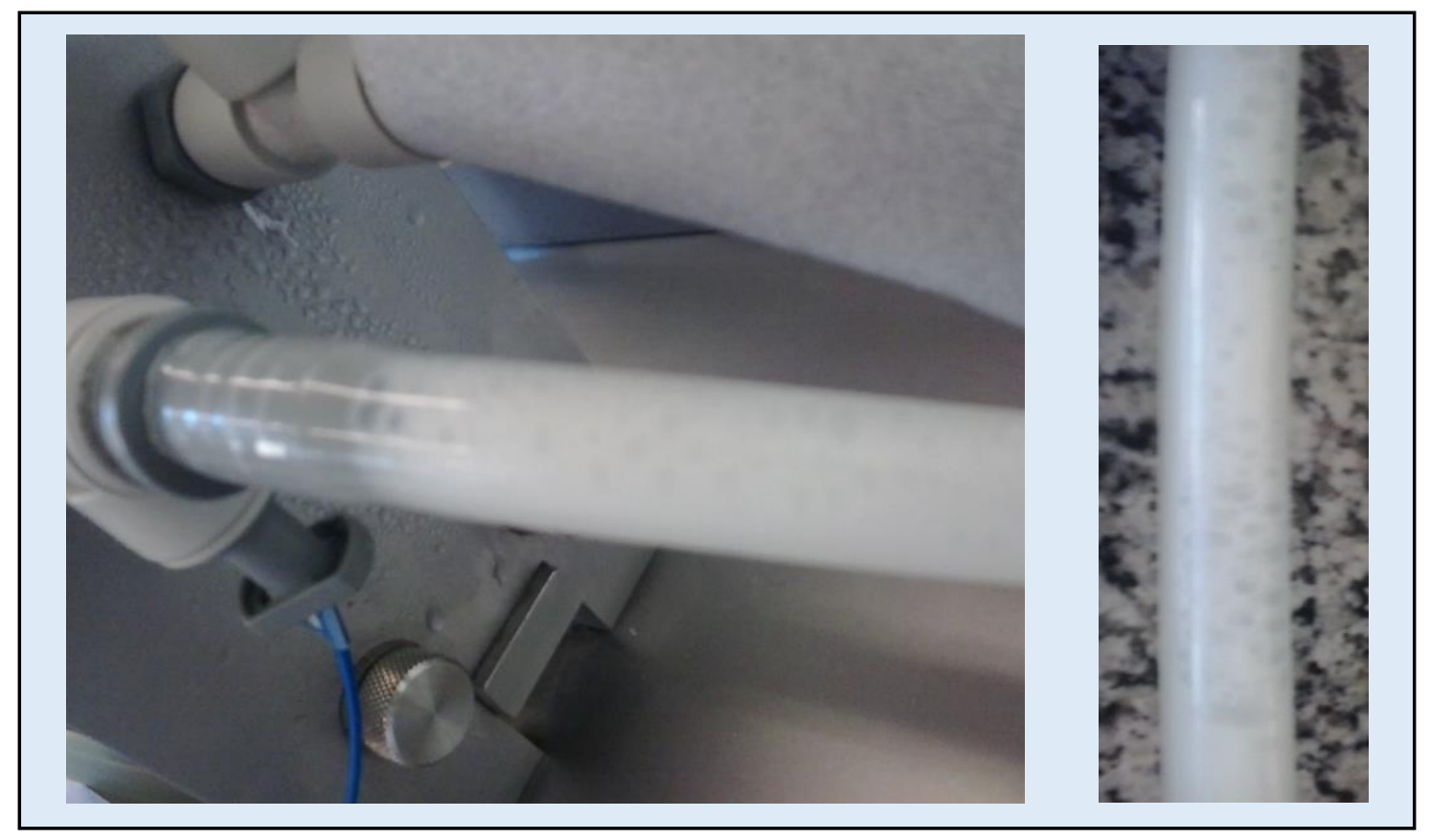

Fonte: elaboração do autor (2016).

Portanto, a partir da Figura 6.42, fica explícito o registro de formação de bolhas de ar durante os ensaios experimentais, as quais podem aumentar o fenômeno da incrustação do produto nas placas, podendo também causar oscilações nos dados de temperatura coletados ao longo do tempo de processo. Por isso que, com o intuito de reduzir a presença de bolhas de ar, algumas plantas de laticínios realizam a desaeração do leite pelo uso de bomba de vácuo (BYLUND, 1995; FELLOWS, 2000). 


\section{CONCLUSÕES}

Desenvolveu-se com sucesso uma modelagem matemática de base fenomenológica para representar a operação transiente (dinâmica) de um pasteurizador genérico, composto pelas seções de aquecimento, regeneração e resfriamento e tubo de retenção e suas conexões, que contemplou o efeito da letalidade para um micro-organismo alvo e o efeito da incrustação do equipamento, para um processo contínuo do tipo HTST, em relação ao espaço e ao tempo.

Foram realizadas diversas simulações com os modelos obtidos, tais como a partida de processo, pasteurização em estado estacionário sem e com incrustação e perturbações dinâmicas no sistema. Os resultados encontrados, representados pelas distribuições de letalidade, históricos de temperatura e fator de incrustação, condizem com o que era esperado. Com isso, a partir da modelagem desenvolvida bem como os resultados teóricos, pôde-se estudar a operação dinâmica e estacionária de um pasteurizador experimental sujeito à incrustação.

Um estudo de caso foi realizado para o pasteurizador de escala laboratorial, (ARMFIELD, UK) modelo FT-43A, considerando a bactéria Coxiella burnetii como indicador alvo para avaliar o efeito da letalidade devido ao tratamento térmico, considerando o processo com e sem incrustação do leite, para diversos cenários operacionais.

Ensaios experimentais com solução de proteína do leite ( $\beta$-lactoglobulina), no pasteurizador avaliado no estudo de caso, foram conduzidos, comprovando o fenômeno da incrustação nas placas do equipamento. A partir dos resultados laboratoriais foi realizado o ajuste dos parâmetros empíricos do modelo empírico da incrustação do produto e os resultados teóricos foram confrontados com os experimentais, sendo o modelo validado satisfatoriamente.

Os modelos obtidos têm potencial para serem usados no dimensionamento, controle e otimização de futuros projetos de pasteurizadores a placas, em processo sujeito à incrustação, visando, deste modo, redução de custos operacionais, perda de qualidade do produto pelo sobreprocessamento e garantindo a sua inocuidade, controlando o subprocessamento, durante a pasteurização contínua de leite. 


\subsection{Trabalhos Futuros}

Como relação às perspectivas de continuação do projeto de pesquisa com pasteurizadores a placas, têm-se as próximas etapas de trabalhos futuros:

$>$ Considerar que o escoamento nos tubos segue regime laminar, deixando a modelagem mais complexa, porém mais realista;

$>$ Modelar o processo em malha fechada, com controlador PID para temperatura do leite, a fim de tornar o sistema mais próximo das indústrias de laticínios;

$>$ Computar no modelo a capacidade calorífica das tubulações, grades conectoras e pedestais;

> Validar os históricos de letalidade do tratamento térmico com um microorganismo de interesse e pelos valores exatos das propriedades termofísicas da solução proteica;

> Estudar os históricos de letalidade para outro micro-organismo de interesse;

> Introduzir a consideração da perda de calor nas extremidades das placas dos trocadores;

> Repetir o procedimento com placas corrugadas;

> Realizar a modelagem fenomenológica da incrustação a fim de obter informações mais detalhadas da deposição do leite no equipamento em processo transitório;

$>$ Criar uma função objetivo com a variável custo e otimizar o processo de pasteurização; 


\section{REFERÊNCIAS BIBLIOGRÁFICAS}

ABU-KHADER, M. M. Plate heat exchangers: Recent advances. Renewable and Sustainable Energy Reviews, 16, 1883-1891, 2012.

AGUIAR, H. F. Modelagem matemática e validação experimental da pasteurização de leite pela avaliação do histórico de temperatura e letalidade em trocador de calor a placas. Dissertação de Mestrado em Engenharia Química apresentada à Escola Politécnica da Universidade de São Paulo (USP), São Paulo. 2009.

AGUIAR, H. F.; GUT, J. A. W. Continuous HTST pasteurization of liquid foods with plate heat exchangers: Mathematical modeling and experimental validation using a time-temperature integrator. Journal of Food Engineering, 123, 78-86, 2014.

AHDB. Agriculture and Horticulture Development Board. Dairy: world milk production, 2015. Disponível:http://dairy.ahdb.org.uk/market-information/supply-production/milkproduction/world-milk-production/\#.VmXXP3arTIW. Acessado em 05/06/2014.

AKAMINE, T. Informes Urbanos: aumenta a temperatura média em SP, n. 9, junho, 2012. Disponível em: http://smdu.prefeitura.sp.gov.br/informes urbanos/pdf/21.pdf. Acessado em $26 / 11 / 2015$.

ALAIS, C. Ciência de la Leche. Barcelona: Editorial Reverté, p. 243-250, 1985.

ALFA LAVAL. Thermal Handbook. Alfa-Laval, Lund, Sweden, 1969.

ALFA LAVAL. Heat Exchanger Guide. Alfa-Laval, Lund, Sweden, 1971.

ALFA LAVAL. Products. The world leader in heat transfer: PHEs, 2014. Disponível em: http://www.alfalaval.com Acesso em 01 de novembro, 2014.

ANSARI, MD. I. A.; SHARMA, M.; DATTA, A. K. Milk fouling simulation in a double tube heat exchanger. International Communications in Heat and Mass Transfer, 30 (5), 707-716, 2003.

AUGUSTIN, W.; GEDDERT, T.; SCHOLL, S. Surface treatment for the mitigation of whey protein fouling. In: Proceedings of 7 th International Conference on Heat Exchanger Fouling and Cleaning-Challenges and Opportunities. The Berkeley Electronic Press, Berkeley, Tomar, Portugal, 2007.

ARMFIELD. Laboratory Pasteuriser: FT43 Laboratory Pasteuriser - Issue 9, 2014. Disponível em: http://discoverarmfield.com/en/products/view/ft43/laboratory-pasteuriser. Acesso em 01 de junho de 2014. 
BALL, C.O.; OLSON, C. W. Sterilization in Food Techonology. McGraw-Hill Book Co., New York, USA, 1957.

BANSAL, B.; CHEN, X. D. A critical review of milk fouling in heat exchangers. Comprehensive reviews in food science and food safety, V.5, p.27-33, 2006.

BARBANO, D. M.; MA, Y.; SANTOS, M. V. Influence of raw milk quality on fluid milk shelf life. Journal of Dairy Science, Lancaster, v. 89, p. E15-E19, 2006.

BEARD, M.; STEINGRABER, G.; DRAGON, A.; SCRUTON, D. Guidelines for effective installation, cleaning and sanitizing of basic parlor milking systems. The dairy Practices Council (DPC). Publication: DPC 2. Newtown, USA, January 2007.

BEHMER, M. L. A. Tecnologia do leite: leite, queijo, manteiga, caseína, iogurte, sorvetes e instalações: produção, industrialização, análise. 15. ed. São Paulo: Nobel, 1987. 320 p.

BELMAR-BEINY, M. T.; GOTHAM, S. M.; PATERSON, W. R.; FRYER, P. J. The Effect of Reynolds Number and Fluid Temperature in Whey Protein Fouling. Journal of Food Engineering, 19, 119-139, 1993.

BELL, R.W.; SANDERS, C. F. Prevention of milk stone formation in a high temperature-shorttime heater by preheating milk, skim milk and whey. J. of Dairy Science 27 (6), 499-504, 1944.

BENNING, R.; PETERMEIJER, H.; DELGADO, A.; HINRICHS, J.; KULOZIK, U.; BECKER, T. Process design for improved fouling behavior in dairy heat exchangers using hybrid modelling. Food and Bioproducts Processing, 81, 266-274, 2003.

BENNET, H. A. E. Aspects of fouling in dairy processing. PhD Thesis - Food Engineering Massey University, New Zeland, 2007.

BENZE, R. V. Modelagem matemática do processo térmico contínuo de alimentos líquidos em trocadores de calor a placas. Dissertação de Mestrado de Engenharia Química da Universidade de São Paulo, 77p., São Paulo, SP, 2013.

BERGMAN, T. L; LAVINE, A. S.; INCROPERA, F. P.; DEWITT, D. P. Heat Exchangers in Fundamentals of Heat and Mass Transferer. $7^{\text {th }}$ edition, Wiley \& Sons Inc., 2011.

BERTELI, M. N.; BERTO, M. I.; VITALI, A. A. Applicability of the Ball method in the calculation of lethality in sterilization processes using water vented steam retorts. Braz. J. Food Technol. Campinas, v. 16, n. 3, p. 243-252, jul, 2013.

BEVIS, M. Full steam ahead-Reduce your Steam Costs. Wiley, 10 January 2015. Disponível em: http://www.wiley.com.au/white-papers/full-steam-ahead-reduce-your-steam-costs/. Acesso em 21 de junho de 2016. 
BIRD, R. B.; STEWART, W. E.; LIGHFOOT, E. N. Transport Phenomena. $2^{\text {nd }}$ edition, John Wiley \& Sons, Inc. USA, 2002.

BOOR, K. J. Fluid dairy product quality and safety: looking to the future. Journal of Dairy Science, Lancaster, v. 84, n. 1, p. 1-11, 2001.

BON, J.; CLEMENTE, G.; VAQUIRO, H.; MULET, A. Simulation and optimization of milk pasteurization processes using a general process simulator (ProSimPlus). Computers and Chemical Engineering 34, 414-420, 2010.

BONIS, M. V.; RUOCCO, G. Fouling of heat exchangers in the dairy industry by coupling flow and kinetics modelling. Excerpt from the Proceedings of the Comsol Users Conference Milano, 2006.

BONIS, M. V.; RUOCCO, G. Conjugate fluid flow and kinetics modeling for heat exchanger fouling simulation. International Journal of Thermal Sciences 48, 2006-2012, 2009.

BOUVIER, L.; MOREAU, A.; RONSE, G.; SIX, T.; PETIT, J.; DELAPLACE, G. CFD model as a tool to simulate b-lactoglobulin heat-induced denaturation and aggregation in a plate heat exchanger. Journal of Food Engineering 136, 56 - 63, 2014.

BOTT, T. R. Fouling of Heat Exchangers. 1st. Ed. New York: Elsevier B. V., 524p., 1995.

BOXLER, C.; AUGUSTIN, W.; SCHOLL, S. Composition of milk fouling deposits in a plate heat exchanger under pulsed flow conditions. J. of Food Eng. 121, 1-8, 2014.

BOXLER, C. AUGUSTIN, W.; SCHOLL, S. Fouling of milk components on DLC coated surfaces at pasteurization and UHT temperatures. Food and Bioproducts Processing, FBP-365; No. of Pages 12, 2012.

BURTON, H. Seasonal variation in deposit formation from whole milk on a heated surface. J. Dairy Res., 34,137-43, 1967.

BURTON, H. Reviews of the Progress of Dairy Science. Section G: Deposits from whole milk in heat treatment plant - a review and discussion. Journal Dairy Res., 35, 317-330, 1968.

BURTON, H. Ultra-high-temperature Processing of Milk and Milk Products. Elsevier Applied Science, London, v. 1, 1988.

BRASIL. Ministério de Estado da Agricultura, Pecuária e Abastecimento (MAPA). Decreto no 1.812, de 8 de fevereiro de 1996. Altera dispositivos do Decreto n ${ }^{\circ} 30.691$, de 29 de março de 1952, que aprovou o Regulamento da Inspeção Industrial e Sanitária de Produtos de Origem Animal, alterado pelo Decreto $\mathrm{n}^{\circ} 1.255$, de 25 de junho de 1962. Diário Oficial da República Federativa do Brasil, Poder Executivo, Brasília, DF, 8 de fevereiro de 1996. Capítulo I, art. 475. 
BRASIL. Ministério da Agricultura, Pecuária e Abastecimento (MAPA). Regulamento da inspeção industrial e sanitária de produtos de origem animal (RIISPOA). Aprovada pelo Decreto 30.6912 de 29/03/1952 e alterado pelo Decreto 1255 de 25/06/1962). Brasília, DF, 1980 .

BRASIL. Ministério da Agricultura, Pecuária e Abastecimento (MAPA). Regulamento da Inspeção industrial e sanitária de Produtos de Origem Animal (RIISPOA). Regulamento da Inspeção Industrial e Sanitária de Produtos de Origem Anima. Aprovado pelo decreto nํㅜ 30.691, de 20 de março de 1952. Brasília, 1952. Disponível em: http://www.agricultura.gov.br/arq editor/file/Aniamal/Mercadolnterno/Requisitos/Regulament olnspecaolndustrial.pdf. Acessado em 05/06/2014.

BRASIL. Agência Nacional de Vigilância Sanitária (ANVISA). Resolução - RDC no 267, de 25 de setembro de 2003. Aprovar o Regulamento Técnico de Boas Práticas de Fabricação para Estabelecimentos Industrializadores de Gelados Comestíveis. Publicada no DOU em 22 de dezembro de 2000, em reunião realizada em 19 de setembro de 2003.

BRASIL. Ministério de Estado da Agricultura, Pecuária e Abastecimento (MAPA). Instrução Normativa $\mathrm{n}^{\circ}$ 51, de 18 de setembro de 2002. Regulamentos Técnicos de Produção, Identidade e Qualidade do Leite tipo A, do Leite tipo B, do Leite tipo C, do Leite Pasteurizado e do Leite Cru Refrigerado e o Regulamento Técnico da Coleta de Leite Cru Refrigerado e seu Transporte a Granel.

BRASIL. Ministério de Estado da Agricultura, Pecuária e Abastecimento (MAPA). Instrução Normativa no 57, de 15 de dezembro de 2011, para regulamentação de produção de queijo artesanal. Disponível em: http://www.agricultura.gov.br/animal/noticias/2011/12/ministerioregulamenta-producao-artesanal-de-queijo. Acessado em 05/06/2014.

BRASIL. Ministério da Agricultura, Pecuária e Abastecimento (MAPA). Plano Mais Pecuária. 1aㅡ edição, Brasília, DF, 2014a. Disponível em: http://www.agricultura.gov.br/arq editor/file/Ministerio/Publicacao v2.pdf. Acessado em 05/06/2014.

BRASIL. Ministério da Agricultura, Pecuária e Abastecimento (MAPA). Gestão Estratégica: Valor Bruto da Produção (VBP). 2014b. Disponível em: http://www.agricultura.gov.br/ministerio/gestao-estrategica/valor-bruto-da-producao. Acessado em 05/06/2014.

BRASIL. Instituto Brasileiro de Geografia e Estatística (IBGE). Indicadores IBGE: Estatística da Produção Pecuária, setembro de 2014; 2014d. Disponível em: http://www.ibge.gov.br/home/estatistica/indicadores/agropecuaria/producaoagropecuaria/aba te-leite-couro-ovos 201402 publ completa.pdf. Acessado em 05/06/2014. 
BRASIL. Instituto Brasileiro de Geografia e Estatística (IBGE). Indicadores IBGE: Estatística da Produção Pecuária, dezembro de 2014; 2014e. Disponível em: http://www.ibge.gov.br/home/estatistica/indicadores/agropecuaria/producaoagropecuaria/aba te-leite-couro-ovos 201403 publ completa.pdf. Acessado em 05/06/2014.

BRASIL. Instituto Brasileiro de Geografia e Estatística (IBGE). Prod. Pec. Munic., Rio de Janeiro, RJ, v. 38, p.1-65, 2010a. Disponível em: http://www.ibge.gov.br/home/estatistica/economia/ppm/2010/ppm2010.pdf. Acessado em 05/06/2014.

BRASIL. Instituto Brasileiro de Geografia e Estatística (IBGE). Prod. Pec. Munic., Rio de Janeiro, RJ, v. 40, p.1-71, 2012b. Disponível em: ftp://ftp.ibge.gov.br/Producao Pecuaria/Producao da Pecuaria Municipal/2012/ppm2012.pd f. Acessado em 05/06/2014.

BRASIL. Instituto Brasileiro de Geografia e Estatística (IBGE). Estatísticas do leite: Principais países produtores de leite no mundo, Tabela 02.12, 2012a. Disponível em: http://www.cnpgl.embrapa.br/nova/informacoes/estatisticas/producao/tabela0212.php.

Acessado em 05/06/2014.

BRASIL. Ministério da Agricultura Pecuária e Abastecimento (MAPA). Instrução Normativa no 51 de 2002. Diário Oficial da República Federativa do Brasil, Brasília, DF, 20 set. 2002. Disponível em: http://extranet.agricultura.gov.br/sislegisconsulta/consultarLegislacao.do?operacao=visualizar\&id=8932. Acessado em 05/06/2014.

BRASIL. Portal Brasil. Rebanho bovino brasileiro cresce e chega a 212,3 milhões de cabeças de gado, 2015. Disponível em: http://www.brasil.gov.br/economia-eemprego/2015/10/rebanho-bovino-brasileiro-cresce-e-chega-a-212-3-milhoes-de-cabecasde-gado. Acessado em 05/06/2014.

BRITO, M. A.; BRITO, J. R.; ARCURI, E.; LANGE, C.; SILVA, M.; SOUZA, G. EMBRAPA: Composição do leite, 2014.2 Disponível em: http://www.agencia.cnptia.embrapa.br/Agencia8/AG01/arvore/AG01 128 21720039243.html . Acessado em 21/12/2014.

BRINKMANN, D. W. Energie- en milieuaspecten van het reinigen van verwerkingsapparatuur. In G. J. M. WOLBERS et al. (Eds.). Milieuaspecten van de bereiding von voedingsmiddelen [Environmental aspects of food manufacture], NIZO Medeling M20, 61-76, NIZO, Ede, 1986.

BYLUND, G. Dairy processing handbook. Tetra Pak Processing Systems AB S-221 86 Lund, Sweden, 1995. 
CASP, A.; ABRIL, J. Processos de conservación de alimentos. Segunda edição. [S.I.]: Mundiprensa, 2003. 494 p.

CASTRO, P.S. MAF 3340-Tecnologia de leites e derivados. Apostila de aulas práticas. Goiânia: Departamento de Matemática e Física. Curso de Engenharia de Alimentos, Universidade Católica de Goiás, 2005. 25p. Disponível em: https://pt.scribd.com/doc/86607445/Apostila-de-Leites-e-Derivados.

CAREZZATO, A.; ALCANTARA, M. R.; TELIS-ROMERO, J.; TADINI, C. C.; GUT, J. A. W. NonNewtonian Heat Transfer on a Plate Heat Exchanger with Generalized Configurations, Chem. Eng. Technol., 2007, 30, No. 1, 21-26.

ÇENGEL, Y.; GHAJAR, A. Heat and Mass Transfer: Fundamentals and Applications. 5. Ed., McGraw-Hill, USA, 2014.

CERF, O.; CONDRON, R. FOR DEBATE: Coxiella burnetii and milk pasteurization: an early application of the precautionary principle? Epidemiol. Infect., 134, 946-951, 2006.

CHATTERTON, D. E. W. et al. Bioactivity of $\beta$-lactoglobulin and $\alpha$-lactalbumiun - Tecnological implications for processing. International Dairy Journal, Barking, v. 16, p. 1229-1240, 2006.

CHANGANI, S. D.; BELMAR-BEINY, M. T.; FRYER, P. J. Engineering and chemical factors associated with fouling and cleaning in milk processing. Experimental Thermal and Fluid Science, v. 14, n. 4, p. 392-406, 1997.

CHENG, H.; FRIIS, A. Operability and Flexibility of Milk Production Line. Food and Bioproducts Processing, v. 85, n. C4, p. 372-380, 2007.

CHEN, H.; HOOVER, D. G. Modeling the combined effect of high hydrostatic pressure and mild heat on the inactivation kinetics of Listeria monocytogenes Scott $A$ in whole milk. Innovative Food Science \& Emerging Technologies, v. 4, p. 25-34, 2003.

CHEN H. Use of linear, Weibull, and log-logistic functions to model pressure inactivation of seven foodborne pathogens in milk. Food Microbiol. 24(3):197-204, 2007.

CHOI, Y.; OKOS, M. R. Thermal Properties of Liquid Foods - Review, In: OKOS, M. R. (Ed.). Physical and Chemical Properties of Food. St. Joseph: ASAE, 1986. p. 35-77.

CHOI, W.; JUN, S.; NGUYEN, L. T.; RUNGRAENG, N.; YI, H.; BALASUBRAMANIAN, S.; PURI, V. M.; LEE, J. 3-D milk fouling modeling of plate heat exchangers with different surface finishes using computational fluid dynamics codes. Journal of Food Process Engineering 36, 439 449, 2013.

CLIAUDAGNE, D., Fouling Costs in the Field of Heat Exchange Equipment in the French Market. In Fouling Mechanisms: Theoretical and Practical Aspects, M. Bohnet, T. R. Bott, A. J. 
Karabelas, P. A. Pilavachi, R. Srmrria, and R. Vidil, Eds., pp. 21-25, Editions Europrennes Thermique et Industrie, Paris, France, 1991.

COSTA, F. M. A.; D'ALESSANDRO, W. T.; CARVALHO, A. L.; JEFONE, M. R.; TANEZINI, C. A.; PONTES, I. S.; FERREIRA, M. L.; SOTÉRIO, N. M. F. Variação do teor de gordura no leite bovino cru. Pesquisa Agropecuária Brasileira, v.27, n.5, p.763-769, 1992.

CORBIN, E. A.; WHITTIER, E. O. The Composition of Milk in Fundamentals of Dairy Chemistry (B. H. Webb and A. H. Johnson, eds.), AVI, Westport, CT, pp. 1 - 36, 1965.

COUSIN, M. A. Presence and activity of psychrotrophic microrganisms in milk and dairy products: a review. Journal of Food Protection, Ames, v. 45, n. 2, p. 172-207, 1982.

WHITE, J.C.D.; DAVIES, D.T. The relationship between the chemical composition of milk and the stability of the caseinate system. I. General introduction, description of samples, methods and chemical composition of samples. J. Dairy Res. 25 : 236-255, 1958.

DALGLEISH, D. G. Denaturation and aggregation of serum proteins and caseins in heated milk. J. Agric. Food Chem. 38, (11), 1995-9, 1990.

DAMODARAN, S; PARKIN, K. L.; FENNEMA, O. R. Fennema's Food Chemistry. 4a edition, In Chapter 15, Milk Characteristics (eds SWAISGOD, H. E.). CRC Press (Taylor \& Francis Group), 2007.

DANNENBERG, F.; KESSLER, H. G. Reaction kinetics of the denaturation of whey proteins in milk, J Food Sci, v.53, p.258-263. 1998.

DANNENBERG, F. Zur Reaktionskinetik der Molkenproteindenaturierung und derem technologischer Bedeutung. Ph. D.Thesis, Technical University Munich, (1986).

DAUFIN, G.; LABBÉ, J. P.; QUEMERAIS, A.; BRULÉ, G.; MICHEL, F.; ROIGNANT, M.; PRIOL, M. Fouling of a heat exchange surface by whey, milk and model fluids. Dairy Sci. Technol.67, $339-364,1987$.

DE BONIS, M. V.; RUOCCO, G. Fouling of heat exchangers in the dairy industry by coupling flow and kinetics modelling. Excerpt from the Proceedings of the COMSOL Users Conference, Milano, 2006.

DE JONG, P. Thermal Processing of Milk in Advanced Dairy Science and Technology. 1 ed (BRITZ, T. J.; ROBINSON, R. K), Blackwell Publishing Ltd., UK, 2008.

DE JONG, P.; VAN DER LINDEN, H. J. L. J. Design and operation of reactors in the dairy industry. Chemical Engineering Science, V. 47, Issues 13-14, October, Pages 3761-3768, 1992.

DE JONG, P. Impact and control of fouling in milk processing. Trends in Food Science and Technology 8, 401-405, 1997. 
DE JONG, P., Modeling and Optimization of Thermal Treatments in Dairy Industry, Ph. D, Deft University, Holanda, 1996.

DE JONG, P.; BOUMAN, S.; VAN DER LINDEN, H. J. L. J. Fouling of heat transfer equipment in relation to the denaturation of $\beta$-lactoglobulin. J. Soc Dairy Technol, 45:3-8, 1992.

DELPLACE, F.; LEULIET, J. C. Modelling fouling of a plate heat exchanger with diferente flow arrangements by whey protein solutions. Food Bioprod. Process 73, 112-120, 1995.

DELPLACE, F.; LEULIET, J.C.; TISSIER, J. P. Fouling experiments of a plate heat exchanger by whey proteins solutions. Trans IChemE C, 72:163-9, 1994.

DELPLACE, F.; LEULIET, J. C.; LEVIEUX, D. A reaction engineering approach to the analysis of fouling by whey proteins of a six-channel-per-pass plate heat exchanger. J. Food Eng. 34:91108, 1997.

EMBRAPA (Empresa Brasileira de Pesquisa Agropecuária). O mercado lácteo brasileiro no contexto mundial, Juiz de Fora, MG, Dezembro, 2010b. Disponível em: http://www.infoteca.cnptia.embrapa.br/bitstream/doc/886169/1/CT104Kennya.pdf. Acessado em 05/06/2014.

ENRIGHT, J. B.; SADLER, W. W.; THOMAS, R. C. Pasteurization of milk containing the organism of $Q$ fever. American Journal of Public Health; 47: 695-700, 1957.

ERABIT, N.; FLICK, D.; ALVAREZ, G. Formation of beta-lactoglobulin aggregates during thermomechanical treatments under controlled shear and temperature conditions. J. Food Eng. 120, 57-68, 2014.

ESTY, J. R.; MEYER, K. F. The heat resistance of the spores of B. botulinus and allied anaerobes. J. Infect. Dis. 34, 65-663, 1922.

FAO - Food and Agriculture Organization of the United Nations. In Milk and milk products, 2014. Disponível em: http://www.fao.org/wairdocs/x5434e/x5434e00.htm\#Contents. Acessado em 20/09/2014.

FDA - Food and Drug Administration. U.S. Department of Health and Human Services. Public Health Service. Grade "A" Pasteurized Milk Ordinance, 2011. Disponível em: http://www.fda.gov/downloads/Food/GuidanceRegulation/UCM291757.pdf. Acessado em 25/10/2014.

FELLOWS, P. Food processing technology: principles and practice. 2nd ed. Boca Raton: Woodhead publishing Ltda e CRC Press LLC, 2000. 575 p. 
GALEAZZOA, F. C. C.; MIURAB, R. Y., GUT, J. A. W.; TADINI, C. C. Experimental and numerical heat transfer in a plate heat exchanger. Chemical Engineering Science. Volume 61, Issue 21, 6 November, Pages 7133-7138, 2006.

GAREDEW, L.; BERHANU, A.; MENGESHA, D.; TSEGAY, G. Identification of gram-negative bacteria from critical control points of raw and pasteurized cow milk consumed at Gondar town and its suburbs, Ethiopia. BMC Public Health, 6 November 2012.

FOGLER, H. S. Elements of chemical engineering. 3. Ed.; Prentice Hall, 1120 p., 1999.

FOX, K. K.; HOLSINGER, V. H.; CAHA, J.; PALLANSCH, M. J. Formation of a Fat Protein Complex in Milk by Homogenization. J. Dairy Sci. 1960; 43: 1396.

FOX, P. F.; McSWEENEY, P. L. H. Dairy Chemistry and Biochemistry. Blackie Academic \& Professional. First edition, NY (USA), 1998.

FOX, K. K.; UNIACKE-LOWE, T.; MCSWEENEY, P. L. H.; O'MAHONY, J. A. Dairy Chemistry and Biochemistry. $2^{\underline{a}}$ edition, Springer, Switzerland, 2015.

FRÜHLING, S. W. Modelagem Matemática do Crescimento Bacteriano no Leite Cru. Dissertação apresentada ao Curso de Pós-Graduação em Modelagem Matemática da Universidade Regional do Noroeste do Estado do Rio Grande do Sul - UNIJUí, como requisito parcial para a obtenção de título de Mestre em Modelagem Matemática, ljuí, RS, Brasil, 2013.

FRYER, P. J.; SLATER, N. K. H. A direct simulation procedure for chemical reaction fouling in heat exchangers. Chem. Eng. J. 31, 97-107, 1985.

FRYER, P. J. The uses of fouling models in the design of food process plant. Journal of the Society of Dairy Technology, 42, 23-30, 1989.

FRYER, P. J.; BELMAR-BEINY, M. T. Fouling of heat exchangers in the food industry: a chemical engineering perspective - Review. Trends in Food Science \& Technology, 1991.

FRYER, P. J.; ROBBINS, P. T.; GREEN, C.; SCHREIER, P. J. R.; PRITCHARD, A. M.; HASTING, A. P. M.; ROYSTON, D. G.; RICHARDSON, J. F. A statistical model for fouling of a plate heat exchanger by whey protein solution at UHT conditions. Trans. Inst. Chem. Eng. 74(C), 189199, 1996.

FRYER, P. J.; SLATER, N. K. H. A direct simulation procedure for chemical reaction fouling in heat exchangers. Chem. Eng. J. 31, 97-107, 1985.

FRYER, P. J.; CHRISTIAN, G. K.; LIU, W. How hygiene happens: physics and chemistry of cleaning. Int. J. Dairy Technol. 59, 76-84, 2006.

GALVÃO JÚNIOR, J. G. B.; RANGEL, A. H. N., DE MEDEIROS, H. R.; DA SILVA, J. B. A.; DE AGUIAR, E. M.; MADRUGA, R. C.; DE LIM JÚNIOR, D. M. Efeito da produção diária e da 
ordem de parto na composição físico-química do leite de vacas de raças zebuínas. Acta Veterinaria Brasilica, v.4, n.1, p.25-30, 2010.

GALEAZZO, F. C.C.; MIURA, R. Y.; GUT, J. A. W.; TADINI, C. C. Experimental and numerical heat transfer in a plate heat exchanger. Chemical Engineering Science 61, 7133 - 7138, 2006.

GAO, R.; VAN HALSEMA, F. E. D.; TEMMINGHOFF, E. J. M.; VAN LEEUWEN, H. P.; VAN VALENBERG, H. J. F.; EISNER, M. D.; GIESBERS, M.; VAN BOEKEL, M. A. J. S. Modelling ion composition in simulated milk ultrafiltrate (SMUF). I: Influence of calcium phosphate precipitation. Food Chemistry 122, 700-709, 2010.

GAVA, A. J. Princípios de tecnologia de alimentos. NBL Editora, São Paulo, 2007.

GEORGIADIS, M. C.; Rotstein, G. E.; Macchietto, S. Modelling, simulation and optimization of milk heat treatment processes under fouling and effect on the plant's flexibility. Publisher: distributed by American Institute of Chemical Engineers, 1997.

GEORGIADIS, M. C.; ROTSTEIN, G.; MACCHIETTO, S. Modeling simulaton and optimization of milk heat treatment processes under fouling and effect on plant's flexibility. In Frontiers in Food Engineering, CoFE 97. AIChE, New York, pp. 382 - 387, 1997.

GEORGIADIS, M. C.; ROTSTEIN, G. E.; MACCHIETTO, S. Optimal design and operation of heat exchangers under milk fouling. Computers \& Chemical Engineering, v. 44, n. 9, p. 20992111, 1998a.

GEORGIADIS, M. C.; ROSTEIN, G. E.; MACCHIETTO, S. Modeling and simulation of shell and tube heat exchangers under milk fouling. Aiche J. 44(4), 959-971, 1998b.

GEORGIADIS, M. C.; MACCHIETTO, S. Dynamic modelling and simulation of plate heat exchangers under milk fouling. Chemical Eng. Science 55, 1605-1619, 2000.

GOTHAM, S. M., FRYER, P. J.; PRITCHARD, A. M. $\beta$-Lactoglobulin denaturation and aggregation reactions and fouling deposit formation; a DSC study. Int. J. Fd. Sci. Technol., in press, 1992.

GOUGOULI, M.; KALANTZI, K.; BELETSIOTIS, E.; KOUTSOUMANIS, K.P. Development and application of predictive models for fungal growth as tools to improve quality control in yogurt production. Food Microbiology 28,1453-1462, 2011.

GRUMMER, R.R. Effect of feed on the composition of milk fat. Journal of Dairy Science, v.74, p.3244-3257, 1991. 
GRUPO TECSUL. Modelos de Trocadores de Calor: Trocador de Calor, 2014. Disponível em: http://www.grupotecsul.com.br/site/Modelos-de-Trocadores-de-Calor/Trocador-de-Calor. Acessado em 01 de novembro de 2014.

GUT, J. A. W. Configurações ótimas para trocadores de calor a placas. Tese de Doutorado em Engenharia da Escola Politécnica da Universidade de São Paulo (USP), São Paulo, 2003.

GUT, J. A. W.; PINTO, J. M. Conhecendo os trocadores de calor a placas. Revista de Graduação da Engenharia Química. São Paulo, v. 1, n. 11, p. 9-16, 2003b. Disponível em: http://www.hottopos.com/regeq11/gut.htm. Acessado em 12 de novembro de 2014.

GUT, J. A. W.; PINTO, J. M. Modeling of plate heat exchangers with generalized configurations. International Journal of Heat and Mass Transfer, 46, 2571-2585, 2003c.

GUT, J. A. W.; PINTO, J. M. Selecting optimal configurations for multisection plate heat exchangers in pasteurization processes. Industrial and Engineering Chemistry Research 42 (24), 6112-6124, 2003d.

GUT, J. A. W., PINTO, J. M. Optimal configuration design for plate heat exchangers. International Journal of Heat andMass Transfer 47 (22), 4833-4848, 2004.

GUT, J. A. W.; PINTO, J. M., GABAS, A. L., TELIS-ROMERO, J. Continuous pasteurization of egg yolk: thermophysical properties and process simulation. Journal of Food Process Engineering, 28 (2), 181-203, 2005.

GUT, J. A. W.; PINTO, J. M. Optimal Design of Continuous termal processing with plate heat exchangers. In: ERDOGDU, F (Ed.). Optimization in Food Engineering. Boca Raton: CRC Press, 597-631, 2009.

GUT, J. A. W. Modelagem matemática e validação experimental da pasteurização de alimentos líquidos em trocadores de calor a placas. Tese de Livre-Docência da Escola Politécnica da Universidade de São Paulo, Dpt. de Eng Química. São Paulo, SP, 2012.

GUT, J. A. W.; FERNANDES, R.; TADINI, C. C.; PINTO, J. M. HTST Milk Processing: Evaluating the Thermal Lethality inside Plate Heat Exchangers (PHE). International Conference on Engineering and Food (ICEF9), 2004. Disponível em: http://sites.poli.usp.br/pqi/lea/docs/icef2004a.pdf. Acessado em 28/11/2015.

GUTIERREZ, C.G.C.C. Distribuição do e tempo de residência em processo de pasteurização com trocador de calor a placas. Dissertação (Mestrado). Escola Politécnica da Universidade de São Paulo, São Paulo, SP, 2008. 
GUTIERREZ, C. G. C. C. Análise dinâmica de um processo contínuo de pasteurização em trocadores de calor a placas. Tese de Doutorado em Engenharia Química pela Escola Politécnica da Universidade de São Paulo (USP). São Paulo, 2013.

GUTIERREZ, C. G. C. C.; DIAS, E. F. T. S.; GUT, J. A. W. Investigation of the residence time distribution in a plate heat exchanger with series and parallel arrangements using a non-ideal tracer detection technique. Applied Thermal Engineering, v.31, n.10, p.1725-1733, 2011.

GUTIERREZ, C. G. C. C. Estudo experimental do fenômeno de incrustação do leite em processos de pasteurização. Relatório de Pós-doutorado da Escola Politécnica da Universidade de São Paulo (USP). Departamento de Engenharia Química. São Paulo, Dezembro, 2015.

GUTIERREZ, C. G. C. C.; DINIZ, G. N.; GUT, J. A.W. Dynamic simulation of a plate pasteurizer unit: Mathematical modeling and experimental validation. Journal of Food Engineering 131, 124-134, 2014.

GUTIERREZ, C. G. C. C; DIAS, E. F. T. S.; GUT, J. A. W. Residence time distribution in holding tubes using generalized convection model and numerical convolution for no-ideal tracer detection. Journal of Food Engineering, 98 (2), 248-256, 2010.

GRIJSPEERDT, K.; MORTIER, L.; DE BLOCK, J.; VAN RENTERGHEM, R. Modelling heat exchangers for the thermal treatment of milk. Mededelingen Faculteit Landbouwwetenschappen Universiteit Gent, 64/5b, 477-483, 1999.

GRIJSPEERDT, K.; HAZARIKA, B.; VUCINIC, D. Application of computational fluid dynamics to model the hydrodynamics of plate heat exchangers for Milk processing. Journal of Food Engineering, v.57, n. 57, p. 237-242, 2003.

GRIJSPEERDT, K.; MORTIER, L.; DE BLOCK, J.; VAN RENTERGHEM, R. Applications of modeling to optimize ultra high temperature milk heat exchangers with respect to fouling. Food Control, 15:117-30, 2004.

HANGOS, K.; CAMERON, I. T. Process Modelling and Model Analysis. Vol. 4, Great Britain: Academic Press, p. 543 e p. 10-30, 2001

HASTING, A. P. M. Practical considerations in the design, operation and control of food pasteurization processes. Food control, v. 3, n. 1, p. 27-32, 1992.

HARDING, F. Compositional quality: milk quality. Glasgow: Blackie Academic Professional, 1995. 165p.

HARPER, W. In: W. HARPER; C. HALL (eds) Dairy Technology and Engineering. AVI, Westport, Connecticut, pp. 141-169, 572, 1976. 
HASTING, A. P. M. Practical considerations in the design, operation and control of food pasteurization processes. Food Control, v. 3, n. 1, p. 27-32, 1992.

HAYES, M. C.; BOOR, K. Raw milk and fluid milk products. In: MARTH, E. H.; STEELE, J. L. Applied Dairy Microbiology. 2th ed. New York: Marcel Dekker, 2001. p. 59-75.

HUCK, J.R.; HAMMOND, B. H.; MURPHY, S. C.; WOODCOCK, N. H.; BOOR. K. J. Tracking spore-forming bacterial contaminants in fluid milk-processing systems. J Dairy Sci, (10) : 4872-83, 2007.

HUCK, J. R.; SONNEM, M.; BOOR, K. J. Tracking heat-resistant, cold-triving fluid milk spoilage bacteria from farm to packaged product. J Dairy Sci; 91 (3) : 1218-28, 2008.

HOFFMANN, W.; KLOBES, H.; KIESNER, C. H. R.; SUHREN, G.; KRUSCH, U.; CLAWINRÄDECKER, I.; LARSEN, P. H. Use of microfiltration for the production of pasteurized milk with extended shelf life. Bulletin of International Dairy Federation, Brussels, v. 311, n. 12, p. 45-46, 1996.

IBARROLA, J. J.; GUILLH, J. C.; SANDOVAL, J. M.; GARCIA-SANZ, M. Modelling of a high temperature short time pasteurization process. Food Control, Vol. 9, No. 5, pp. 267-277, 1998.

IBARROLA, J. J.; SANDOVAL, J. M.; M., GARCIA- SANZ, M.; PINZOLAS, M. Predictive control of a hiht temperature-short time pasteurization process. Control engineering practice, v. 10, n. 7, p. 713-725, 2002.

IGUAL, M.; GARCÍA-MARTÍNEZ, E.; CAMACHO, M. M.; MARTÍNEZ-NAVARRETE, N. Effect of thermal treatment and storage on the stability of organic acids and the functional value of grapefruit juice. Food Chemistry 118, 291-299, 2010.

INMET - Instituto Nacional de Meteorologia. Clima: gráficos, 2014. Acessado em 20/12/2014. Disponível em: http://www.inmet.gov.br/portal/index.php?r=clima/graficosClimaticos

JACOBS, M. B. Milk, cream and dairy products. In JACOBS, M. B. The chemistry and technology of food and food products. 2. Ed. New York: Interscience, v. 2, 1951.

JAY, J.M. Microbiología Moderna de los Alimentos. 3. ed. Zaragoza: Acribia, 1994. 804 p. JAY, J. M. Microbiologia de Alimentos. 6ª edição. Editora Artmed. Porto Alegre (RS), 2005.

JENSEN, R. G.; FERRIS, A. M.; LAMMI-KEEFE, C. J. The Composition of Milk Fat. Journal of Dairy Science. Volume 74, Issue 9, Pages 3228-3243, 1991.

JEURNINK, T. J. M. Fouling of heat exchangers by fresh and reconstituted milk and the influence of air bubbles. Milchwissenschaft 50, 189-193, 1995. 
JEURNINK, T.J.M.; DE KRUIF, C.G. Calcium concentration in milk in relation to heat stability and fouling. Netherlands Milk and Dairy Journal 49, 139-148, 1995.

JEURNINK, T. J. M. Milk fouling in heat exchangers. Thesis Landbouwuniversiteit Wageningen. Omslagontwerp: Resi Coolen Druk: Ponsen \& Looijen bv, Wageningen, 1996.

JIN, Z.; LEE, Y.; CHOI, S.; JEONG, H. Design and Performance of Pressure Drop and Flow Distribution to the Channel in Plate Heat Exchanger. EngOpt 2008 - International Conference on Engineering Optimization. Rio de Janeiro, Brazil, 01 - 05, June, 2008.

JUNG, A.; FRYER, P.J. Optimising the quality of safe food: computational modelling of a continuous sterilisation process. Chemical Engineering Science, v.54, n.6, 1999, p.717-730. JUN, S.; PURI, V. M.; ROBERTS, R. F. A dynamic model for thermal performance of plate heat exchangers. Transactions of the ASAE, 47(1), 213-222, 2003.

JUN, S.; PURI, V. M.; ROBERTS, R. F. A dynamic 2D model for thermal performance of plate heat exchangers. Trans. ASAE 47(1), 213-222, 2004.

JUN, S.; PURI, V. M. A 2D dynamic model for fouling performance of plate heat exchangers. J. Food Eng. (In Review), 2004.

JUN, S.; PURI, V. M. 3D milk-fouling model of plate heat exchangers using computational fluid dynamics. Int. J. Dairy Technol. 58, 214-224, 2005a.

JUN, S.; PURI, V. M. A 2D dynamic model for fouling performance of plate heat exchangers. Journal of Food Engineering 75, 364-374, 2006.

KAKAÇ, S.; LIU, H. Heat Exchangers: Selection, rating and thermal Design. 2.ed. Boca Raton: CRC Press, 2002.

KAKAÇ, S.; LIU, H.; PRAMUANJAROENKIJ, A. Fouling of Heat Exchangers in Heat Exchangers: Selection, Rating, and Thermal Design. Third edition, CRC Press, USA, 2012. KAPUSTENKO, P. O.; TOVAZHNYANSKY, L. L.; ARSENYEVA, O. P.; YUZBASHYAN, A. P. Mitigation of Fouling in Plate Heat Exchangers for Process Industries. Chemical Engineering Transactions, 29, 1441-1446, 2012.

KESSLER, H. G. Dairy Technology in Food and Bio Process Engineering. Verlag A.Kessler (Publishing House A. Kessler), Agnes-Bernauer-Str. 174, D-80687 München (Munich) Germany, 2002.

KERN, D. Q.; SEATON, R. A. A Theoretical Analysis of Thermal Surface Fouling. British Chemical Engineering, vol. 4, no. 5, pp. 258-262, 1959. 
KHAN, N. A.; RAHMAN, W. Modelling and Simulation of Plate Heat Exchanger. International Journal of Mechanical Engineering, Vol 2, Issue 1, p. 22, 2012.

KHO, T.; MÜLLER-STEENHAGEN, H. M. An experimental and numerical investigation of heat transfer fouling and fluid flow in flat plate heat exchangers. Trans. IChemE, Vol 77, Part A, March, 1999.

KIM, H. B.; TADINI, C. C.; SINGH, R. K. Heat transfer in a plate exchanger during pasteurization of Orange juice. Journal of Food Engineering, 42, 79-84, 1999.

KREITH, F.; MANGLIK, M. R.; BOHN, M. Principles of Heat Transfer. Cengage Learning; 7 edition, USA, 2010.

LADO, B. H.; YOUSSEF, A. E. Alternative Food-Preservation Technologies: Efficacy and Mechanisms. Microbes and Infections, v. 4, n. 4, p. 433-440, 2002.

LALANDE, M.; RENÉ, F. Fouling by milk and dairy product and cleaning of heat exchanger surfaces. In Fouling Science and Technology (NATO ASI Ser. E, Vol. 145) (Melo, L., Bolt, T R. and Bernardo, C.A., eds), pp. 557-573, Kluwer Academic, Amsterdam, The Netherlands: Kluwer, 1988.

LALANDE, M.; TISSIER, J. P.; CORRIEU, G. Fouling of heat transfer surfaces related to $\beta$ lactoglobulin denaturation during heat processing of milk. Biotechnol. Progress, 1, 131-139, 1985.

LALANDE, M.; TISSIER, J. P.; CORRIEU, G. Fouling of a Heat-exchanger used in ultra-hightemperature sterelization of milk. J. of Dairy Research, V. 51, I. 04, pp 557-568, 1984.

LAWRY, F.J. Plate-type heat exchangers. Chemical Engineering (29), 89-94, 1959.

LECLERCQ-PERLAT, M. N.; LALANDE, M. A review on the modelling of the removal of porous contaminant deposited on heat transfer surfaces. International Chemical Engineering, 31, 74-93, 1991.

LENNETTE, E. H.; CLARK, W. H.; ABINANTI, M.M.; BRUNETTI, O.; COVERT, J. M. Q fever studies XIII. The effect of pasteurization on Coxiella burnetti in naturally infected milk. American Journal of Hygiene; 55: 246-253, 1952.

LEHNER, A.; RIEDEL, K.; EBERL, L.; BREEUWER, P.; DIEP, B.; STEPHAN, R. Biofilm formation, extracellular polysaccharide production, and cell-to-cell signaling in various Enterobacter sakazakii strains: aspects promoting environmental persistence. Journal of Food Protection, 68, 2287-2294, 2005. 
LEI, C.; PENG, Z.; DAY, T.; YAN, X.; BAI, X.; YUAN, C. Experimental observation of surface morphology effect on crystallization fouling in plate heat exchangers. International Commications in Heat and Mass Transfer, v.38, n.1, p.25-30, 2011.

LEEDER, J. G. Milkstone - it can be controlled. J. of Dairy Science 39 (2), 229-231, 1956.

LEVENSPIEL, O. Engenharia das Reações Químicas, Vol. 1 e 2 , Edgard Blucher Ltda., São Paulo, 2007

LEGUÉRINEL, I.; SPEGAGNE, I.; COUVERT, O.; GAILLARD, S.; MAFART, P.; Validation of an overall model describing the effect of three environmental factors on the apparent $D$-value of Bacillus cereus spores. International Journal of Food Microbiology, Elsevier, 22 Dec 2011.

LEGHERINEL, I.; COUVERT, O.; MAFART, P.; Relationship betwenn the apparent heat resistence of Bacillus cereus spores and the $\mathrm{pH} \mathrm{NaCl}$ concentration of the recovery medium. International Journal of Food Microbiology, Amsterdan, v. 55, p. 223 - 227, 2000.

LEWIS, M.; HEPPELL, N. Continuous thermal processing of foods: pasteurization and UHT sterilization. Gaithersburg: Aspen Publishers, 2000. 447p.

LEWIS, M. J.; DEETH, H. C. Heat Treatment of Milk in Milk Processing and Quality Management (TAMIME, A. Y.). Wiley-Blackwell, A John Wiley \& Sons, Ltd., Publication Ltd, United Kingdom (UK), 2009.

LI, W.; LI, H.; LI, G.; YAO, S. Numerical and experimental analysis of composite fouling in corrugated plate heat exchangers. International Journal of Heat and Mass Transfer 63351 360, 2013.

LIMA, U. A. Matérias-primas dos alimentos. Editora Blucher, 1a edição, Cap. 10., São Paulo, 2010.

LIVNEY, Y. D. Milk proteins as vehicles for bioactives. Current Opinion in Colloid \& Interfaces Science, Israel, v. 15, p. 73-83, 2010.

LOURENÇO, E. J. Tópicos de proteínas de alimentos. Jaboticabal, São Paulo: Edição Funep, Capítulo 5, p.179-231, 2000.

LYSTER, R. L. J. The composition of milk deposits in an ultra-high-temperature plant. J. Dairy Res. 32, $203-208,1965$.

MAHONEY, R. R. Lactose: Enzmatic modification. In: Lactose, water, salts and vitamins. Advanced Dairy Chemistry, v. 3, p. 77-125, 1997.

MAHDI, Y.; MOUHEB, A.; OUFER, L. A dynamic model for milk fouling in a plate heat exchanger. Applied Mathematical Modelling 33, 648-662, 2009. 
MAHDI, Y.; LOUNIS, O. Milk fouling in a plate heat exchanger using dynamic and artificial neural networks models. Journal of Heat and Mass Transfer, Vol 3, Issue 3, Pg. 167 - 197, 2009.

MALTEZOU, H. RAOULT, D. Q fever in children. Lancet Infectious Clinical Diseases, 2: 686$691,2002$.

MANIK, M. H.; BILDEA, C. S.; GRIEVINK, J.; MARSHMAN, C. Modelling and optimisation of milk pasteurisation processes. Computer Aided Chemical Engineering, v. 18, p. 955-960, 2004.

MARRIE, T.; RAOULT, D. Q fever - a review and issues for the next century. International Journal of Antimicrobial Agents; 8: 145-161, 1997.

MAROULIS, Z. B.; SARAVACOS, G. D. Food Process Design. CRC Press, USA: NY, 2003.

MCKELLAR, R. C.; PIYASENA, P. Predictive modelling of inactivation of bovine milk a-Lfucosidase in a high-temperature short-time pasteurizer. Inter. Dairy Journal, 10 , 1-6, 2000.

MCKELLAR, R. C.; PIYASENA, P. Predictive modelling of inactivation of Listeria spp. in bovine milk during high-temperature short-time pasteurization. International Journal of Food Microbiology 39, 167-173, 1998

MELNIK, B. C.; JOHN, S. M.; BASTOS, P. C.; CORDAIN, L. The impact of cow's milk-mediated mTORC1-signaling in the initiation and progression of prostate cancer. Nutrition \& Metabolism, 9:74, 2012

MENEZES, M. F. C.; SIMEONI, C. P.; ETChePARE, M. A.; HUERTA, K.; BORTOLUZZI, D. P. MENEZES, C. R. Microbiota and coservation of milk. Revista Eletrônica em Gestão, Educação e Tecnologia Ambiental. v. 18. Ed. Especial Mai. 2014, p. 76-89.

Miguel, E. M.; CARVAlHO, A. F.; ANDRADE, N. J.; PIRES, A. C. S.; PAULA, J. C. J.; COSTA, R. G. B. Biofilms formation in heat exchangers and its effects on milk and dairy products. Rev. Inst. Laticínios Cândido Tostes, Juiz de Fora, v. 69, n. 1, p 53-63, 2014.

MIURA, R. Y. Estudo de troca térmica em um trocador de calor a placas com configurações generalizadas. Relatório de iniciação científica FAPESP. Orientador: Jorge Andrey Wilhelms Gut. Escola Politécnica da Universidade de São Paulo, Dpt. de Engenharia Química. São Paulo, 2006.

MONTEIRO, A. A.; PIRES, A. C. S.; ARAÚJO, E. A. Tecnologia de Produção de Derivados do Leite. Minas Gerais, Editora UFV, 2011.

MODLER, H. W. Milk processing. In: NAKAI, S.; MODLER, W. (Eds.). Food proteins: processing applications. Wiley-VCH, Inc., p.1-21, 2000. 
MOKHTAR, W. M. F. W.; TAIP, F. S.; AZIZ, N. A.; NOOR, S. B. M. Process Control of Pink Guava Puree Pasteurization Process: Simulation and Validation by Experiment. Interna. J. on Advanced Sci. Eng. Information Technology, vol 2, 2012.

MÜLLER-STEINHAGEN, H. Heat Exchanger Fouling: Mitigation and Cleaning Techniques. Publico Publications, IchemE, Germany, 2000.

MÜLLER-STEINHAGEN, H. Heat Transfer Fouling: 50 Years After the Kern and Seaton Model. Heat Transfer Engineering, Volume 32, 1 - 13, Issue 1, 2011.

MURUGESAN, M. P.; BALASUBRAMANIAN, R. To Study the Fouling of Corrugated Plate Type Heat Exchanger in the Dairy Industry. Research Journal of Engineering Sciences. Vol. 2 (1), 5-10, January, 2013.

NA, B.; WEBB, R. L. A fundamental understanding of factors affecting frost nucleation. International Journal of Heat and Mass Transfer 46 3797-3808, 2003.

NARATARUKSAA, P.; TRIRATANAA, P.; PANA-SUPPAMASSADUA, K.; HEGGSB, P. J.; TIAC, $S$. Dynamic simulation of plate and frame heat exchanger undergoing food fouling: coconut milk fouling case study. ScienceAsia 34: 229-237, 2008.

NDOYE, F. T.; ERABIT, N.; ALVAREZ, G.; FLICK, D. Influence of whey protein aggregation on the residence time distribution in a tubular heat exchanger and a helical holding tube during heat treatment process. J. of Food Eng. 112, 158-167, 2012.

NICKERSON, T. A. Lactose. In: Fundamentals of Dairy Chemistry (B. H. Webb and A. H. Johnson, eds.), AVI, Westport, CT, pp. 224-260, 1965.

NOGUEIRA, F. A. G.; CANNIATTI-BRAZACA, S. G. Boletim do Centro de Pesquisa de Processamento de Alimentos (B CEPPA), Curitiba v. 26, n. 2, p. 213-228, jul./dez, 2008.

NÖRNBERG, M. F. B. L.; TONDO, E. C.; BRANDELLI, A. Bactérias psicrotróficas e atividade proteolítica no leite cru refrigerado. Acta Scientiae Veterinariae, Porto Alegre, v. 37, n. 2, p. 157-163, 2009.

ORDOÑEZ, J. A. Tecnologia de alimentos. São Paulo: Ed. Artmed, 2005, v. 1 e 2.

PATEL, J. S.; BANSAL, B.; JONES, M. I.; HYLAND, M. Fouling behaviour of milk and whey protein isolate solution on doped diamond-like carbon modified surfaces. Journal of Food Engineering 116, 413-421, 2013.

PATERSON, W. R.; FRYER, P. J. A reaction engineering theory for the fouling of surfaces. Chemical Engineering Science 43, 1714-1717, 1988.

PEDRAS, M. M. Avaliação de propriedades físico-químicas e funcionais de leite processado por tecnologia de homogeneização a ultra-alta pressão. Dissertação 
(Mestrado) - Universidade Estadual de Campinas (UNICAMP). Faculdade de Engenharia de Alimentos. Programa de Pós-Graduação: Programa em Tecnologia de Alimentos Campinas, 2007

PELCZAR, M.; REID, R.; CHAN, E. C. S.; Microbiology, MacGraw-Hill: São Paulo, cap 39, 1981. PETERMEIER, H.; BENNING, R.; DELGADO, A.; KULOZIK, U.; HINRICHS, J.; BECKER, J. Hybrid model of the fouling process in tubular heat exchangers for the dairy industry. Journal of Food Engineering 55, 9-17, 2002.

PETERS, M. S.; TIMMERHAUS, K. D. Plant design and economics for chemical engineers, $4^{\text {th }}$ ed. Mc Graw-Hill, New York, USA, 1991.

PETIT, J.; HERBIG, A. L.; MOREAU, A.; DELAPLACE, G. Influence of calcium on betalactoglobulin denaturation kinetics: implications in unfolding and aggregation mechanisms. J. Dairy Sci. 94, 5794-5810, 2011.

PETIT, J.; SIX, T.; MOREAU, A.; RONSE, G.; DELAPLACE, G. $\beta$-lactoglobulin denaturation, aggregation, and fouling in a plate heat exchanger: Pilot-scale experiments and dimensional analysis. Chemical Engineering Science, 101, 432-450, 2013.

PEREDA, J. A. O.; RODRIGUEZ, M. I. C.; ÁlVAREZ, L. F.; SANZ, M. L. G.; MiNGUILLÓN, G. D. G. F.; PERALES, L. H.; CORTECERO, M. D. S. Tecnologia de Alimentos. v.2. Porto Alegre: Artmed, 2005. 279 p.

PFLUG, I. J. Microbiology and Engineering of Sterilization Processes. 7ed, 1990.

PHE Ltda. São Paulo. Trocador de Calor APV. Disponível em: http://www.phe.com.br/ingles/ Acessado em 01/11/2014.

PICHITVITTAYAKARM, W.; NARATARUKSA, P.; HEGGS, P. J.; TIA, S. Effects of fluid flowrate on coconut milk fouling at pasteurization temperature $\left(70^{\circ} \mathrm{C}-74.5^{\circ} \mathrm{C}\right)$. Songklanakarin $\mathrm{J}$. Sci. Technol. (6): 1275-1288, 2006.

PINTO, J. M.; GUT, J. A. W. A Screening Method for the Optimal Selection of Plate Heat Exchanger Configurations. Braz. J. Chem. Eng., 19 (4), 433, 2002.

PINTO, C. L. O.; MARTINS, M. L.; VANETTI, M. C. D. Qualidade microbiológica de leite cru refrigerado e isolamento de bactérias psicrotróficas proteolíticas. Ciênc. Tecnol. Aliment., Campinas, 26(3): 645-651, jul.-set. 2006.

PINHEIRO, A. J. R.; MOSQUIM, M. C. A. V. Processamento de leite de consumo. Dep. Tecnologia de Alimentos. UFV: Viçosa, MG, Imp. Univ., 430p., 1991. 
PIEPIÓRKA-STEPUK, J.; DIAKUN, J. Numerical analysis of fluid flow velocity between plates channel of heat exchanger by different surface configuration in reference to the effects of cleaning. Ital. J. Food Sci., vol. 26, 2014.

PICHITVITTAYAKARN, W.; NARATARUKSA, P.; HEGGS, P. J.; TIA, S. Effects of fluid flowrate on coconut milk fouling at pasteurization temperature $\left(70^{\circ} \mathrm{C}-74.5^{\circ} \mathrm{C}\right)$. Songklanakarin J. Sci. Technol., Vol.28 No.6 Nov. - Dec., 2006

PREMATHILAKA, S. S.; HYLAND, M. M.; CHEN, X. D.; WATKINS, L. R.; BANSAL, B. Interaction of whey protein with modified stainless steel surfaces. Proceedings of 7th International Conference on Heat Exchanger Fouling and Cleaning, pp. 150-121, ECl Symposium Series, Volume RP5, Article 21, tomar, Portugal, 2007.

UNITED STATES DEPARTMENT OF AGRICULTURE (USDA). Foreign Agricultural Service. Livestock and Poultry: world markets and trade. Washington, D. C., USA, Apr. 2014. Disponível em: http://www.fas.usda.gov/psdonline/circulars/livestock poultry.pdf.

REBELLO, W. J.; RICHLEN, S. L.; CHILDS, F. The Cost of Heat Exchanger Fouling in the US Industries, Report no. EGG-M-39187. Department of Energy, Washington, DC, USA, 1988.

REINEMANN, D. J.; WOLTERS, G. M. V. H.; BILLON, P.; LIND, O.; RASMUSSEN, M. D. Review of practices for cleaning and sanitation of milking machines. Bulletin of the International Dairy Federation. No. 381, p.4-18; 2003.

RENNER, E. Milk and Dairy Products in Human Nutrition, N-GmbH., Volkswirtschaftlicher Verlag, Munich, 1983.

REZER, A. P. S. Avaliação da qualidade microbiológica e físico-química do leite UHT integral comercializado no rio grande do sul. [Dissertação de Mestrado do Programa de Pós-Graduação em Ciência e Tecnologia dos Alimentos da Universidade Federal de Santa Maria]. Santa Maria, 31 de março de 2010.

RIBEIRO, C. P.; CANO ANDRADE, M. H. An algorithm for steady state simulation of plate heat exchangers. J. Food Eng. 53, 59-66, 2002.

ROSMANINHO, R.; MELO, L. F. Protein-calcium phosphate interactions in fouling of modified stainless-steel surfaces by simulated milk. Int. Dairy J. 18 (1), 72 - 80, 2008.

ROSMANINHO, R.; RIZZO, G.; MULLER-STEINHAGEN, H.; MELO, L. F. Deposition from a milk mineral solution on novel heat transfer surfaces under turbulent flow conditions. Journal of Food Engineering 85, 29-41, 2008.

ROLLEMA, H. S. Casein association and micelle formation. In: FOX, P.F. (Ed.). Advanced dairy chemistry - 1. Proteins. London: Elsevier Applied Science, p.61-86, 1992. 
USDA - UNITED STATES DEPARTMENT OF AGRICULTURE. Foreign Agricultural Service Dairy: World Markets and Trade, jul 2014. Disponível em: http://usda.mannlib.cornell.edu/usda/current/dairy-market/dairy-market-07-17-2014.pdf

Acesso em: 10 de novembro de 2014.

SANDU, C.; LUND, D. Fouling of heat transfer equipment by food fluids: Computational models. A.I.Ch. E. Symp. Ser. 78, 12-30, 1982.

SANTOS, A. S.; PIRES, C. V.; SANTOS, J. M.; COSTA SOBRINHO, P. S. Crescimento de microorganismos psicrotróficos. Alim. Nutr. = Braz. J. Food Nutr., Araraquara, v. 24, n. 3, p. 297300, jul./set. 2013.

SANTOS, A. L.; PEREIRA, D. B. C. The formation of fouling in milk processing. Rev. Inst. Latic. Cândido Tostes, Mar/Abr, n. 361, 63: 13 -2 1, 2008.

SANTOS, O.; NYLANDER, T.; RIZZO, G.; MÜLLER-STEINHAGEN, H.; TRÄGÅRDH, C.; PAULSSON, M. Study of whey protein adsorption under turbulent flow. In: $2003 \mathbf{E C I}$ Conference on Heat Exchanger Fouling and Cleaning: Fundamentals and Applications, Santa Fe, NM, USA, vol. RP1. The Berkeley Electronic Press, Berkeley, CA, pp. 175-183, Engineering Conferences International, 2003a.

SANTOS, O.; NYLANDER, T.; PAULSSON, M.; TRÄGÅRDH, C. Whey protein adsorption onto steel surfaces-effect of temperature, flow rate, residence time and aggregation. J. Food Eng. 74 (4), 468-483, 2006.

SANTOS, A. L.; PEREIRA, D. B. C.; SARAIVA, C. B. A formação do Fouling e seus impactos no processamento e limpeza de indústrias de laticínios (Parte 1). Revista Leite e Derivados, n.125, p.54-65, março/abril 2011a.

SANTOS, A. L.; PEREIRA, D. B. C.; SARAIVA, C. B. A formação do Fouling e seus impactos no processamento e limpeza de indústrias de laticínios (Parte 2). Revista Leite e Derivados, n.126, p.80-84, maio/junho, 2011 b.

SANTOS, M.V.; MA, Y.; BARBANO, D.M. Effect of somatic cell count on proteolysis and lipolysis in pasteurized fluid milk during shelf-life storage. J Dairy Sci 86 (8) :2491-503, 2003b.

SARAVACOS, G. D.; KOSTAROPOULOS, A. E. Handbook of Food Processing Equipement. New York: Kluwer Academic / Plenum Publishers, 2002.

SCHMIDT, D. G. Colloidal Aspects of Casein. Netherlands Milk and Dairy Journal, 34:42-64, 1980.

SCHMIDT, V. S. J.; KAUFMANN, V.; KULOZIK, U.; SCHERER, S.; WENNING, M. Microbial biodiversity, quality and shelf life of microfiltered and pasteurized Extended Shelf Life (ESL) 
milk from Germany, Austria and Switzerland. International Journal of Food Microbiology, Amsterdam, v. 154, n. 1-2, p. 1-9, 2012.

SCHREIER, P. J. R; FRYER P. J. Heat exchanger fouling: a model study of the scaleup of laboratory data. Chem Eng Sci 50 (8):1311-21, 1995.

SCHUKKEN, Y. H.; WILSON, D. J.; WELCOME, F. et al. Monitoring udder health and milk quality using somatic cell counts. Vet. Res., v.34, p.579-596, 2003.

SEBORG, D.; EDGAR, T.; MELLICHAMP, D. Process Dynamics and Control. 2 ed. New York, John Wiley \& Sons, 2004.

SEC HEAT EXCHANGER. SEC Plate and Frame. Technical Details: Construction Features of the Plate and Frame Heat Exchanger, 2014. Disponível em: http://www.secplateandframe.com/tech.html. Acessado em: 01/11/2014.

SGARBIERI, V. C. Proteínas em alimentos proteicos: propriedades-degradaçõesmodificações. São Paulo: Varela; 1996. 517p.

SGARBIERI, V. C. Physiological-functional properties of milk whey proteins. Rev. Nutr. vol. 17, no. 4, Campinas Oct./Dec., 2004.

SGARBIERI, V. C. Review: Structural and Physicochemical Properties of Milk Proteins. Braz. J. Food Technol., v.8, n.1, p. 43-56, jan./mar., 2005.

SHARIFI, F.; NARANDJI, M. R. G. DYNAMIC SIMULATION OF PLATE HEAT EXCHANGERS. International Communications in Heat and Mass Transfer, Vol. 22, No. 2, pp. 213-225, 1995.

SHAH, R. K.; SEKULIC, D. P. Fundamentals of Heat Exchanger Design. John Wiley \& Sons, New Jersey, USA, 2003.

SHAH, R. K. Heat Exchange Basic Design Methods. In: KAKAÇ, S.; SHAH, R. K.; BERGLES, A. E. (eds.) Low Reynolds Number Flow Heat Exchangers. NY: Hemisphere, p. 21-72, 1983.

SHERBON, J.W. Physical properties of milk, in Fundamentals of Dairy Chemistry, 3rd edn (eds.) N.P. Wong, R. Jenness, M. Keeney and E.H. Marth), Van Nostrand Reinhold, New York, pp. 409-60, 1988.

SILVA, A. P.; CARVALHO, I. T.; LIMA, M. G. A. Qualidade sanitária de queijo prato, comercializado em supermercados de pequeno e médio porte na cidade de Recife, PE. Higiene Alimentar, v. 22, n. 158, p. 92-97, jan/fev., 2008.

SILVA, J. A. Tópicos da Tecnologia dos Alimentos. São Paulo: Livraria Varela, 2000. 325p. 
SMIT, G. Dairy Processing: improving quality. Woodhead Publishing Limited and CRC Press LLC, USA, 2003.

SINGH, H.; MCCARTHY, O.J.; LUCEY, J.A. Physico-chemical properties of milk, in Advanced Dairy Chemistry, Vol. 3: Lactose, Water, Salts and Vitamins, (ed. P.F. Fox), Chapman \& Hall, London, pp. 469-518, 1997.

SOUZA, G.N. et al. Variação da contagem de células somáticas em vacas leiteiras de acordo com patógenos da mastite. Arquivo Brasileiro de Medicina Veterinária e Zootecnia, v. 61, n. 5, p. 1015-1020, 2009.

SOUZA, M. R.; RODRIGUES, R.; FONSECA, L. M.; CERQUEIRA, M. M. O. P. Pasteurização do leite. Caderno Técnico da Escola de Veterinária da UFMG, n. 13, p.85-93, 1995.

SRIHARI, N.; RAO, B.; VAS, S. K. Transient response of plate heat exchangers considering effect of flow maldistribution. International Journal of Heat and Mass Transfer, v. 48, n. 15, p. 3231-3243, 2005.

TAMIME, A. Y. Properties and Constituents of Cow's Milk (HUPPERTZ, T.; KELLY, A. L.) in Milk Processing and Quality Management. Wiley-Blackwell, A John Wiley \& Sons, Ltd., Publication Ltd, United Kingdom (UK), 2009.

TAMIME, A. Y.; DEETH, H. C. Yogurt: technology and biochemistry. Journal of Food Protection, Ames, v. 43, n. 12, p. 939-971, 1980.

TAMIME, A.Y., ROBINSON, R.K. Yogurt: ciencia y tecnologia. Zaragoza: Acribia, p. 368, 1991.

TAMANINI, R.; SILVA, L. C. C.; MONTEIRO, A. A.; MAGNANI, D. F.; BARROS, M. A. F.; BELOTI, V. Avaliação da qualidade microbiológica e dos parâmetros enzimáticos da pasteurização de leite tipo C produzido na região norte do Paraná. Ciências Agrárias, Londrina, v.28, n.3, p.449-454, jul/set, 2007.

TEJEDA, M.U. Estúdio de la formación de crosta en un intercambiador de calor de placas. Tese (Graduação em Engenharía de Alimentos) - Departamento de Ingeniería Química y Alimentos, Escuela de Ingeniería, Universidad de las Américas. Puebla-México, 2003.

TELEKEN, J. T.; ROBAZZA, W. S.; GOMES, G. A. Mathematical modeling of microbial growth in milk. Ciênc. Tecnol. Aliment., Campinas, 31(4): 891-896, out.-dez. 2011.

TE GIFFEL, M. C.; VAN ASSELT, A. J. Hygiene Practices in Liquid Milk Dairies in Milk Processing and Quality Management (ed. TAMIME, A. Y). Wiley-Blackwell, A John Wiley \& Sons, Ltd., Publication Ltd, United Kingdom (UK), 2009.

TOMBINI, H.; DALLACOSTA, M. C.; BLEIL, R. A. T.; ROMAN, J. A. Consumo de leite de vaca entre agricultores. Alim. Nutr., Araraquara, v. 23, n. 2, p. 267-274, 2012. 
TRIOLA, M. F. Introdução à Estatística. Tradução: Vera Regina Lima de Farias e Flores; revisão técnica: Ana Maria Lima de Farias e Flores. Rio de Janeiro: LTC, 2005.

TRONCO, V. M. Manual para inspeção da qualidade do leite. 3. ed. Santa Maria: Ed. UFSM, 2008. 203 p.

VEITH, P. D.; REYNOLDS, E. C. Production of a high gel strength whey protein concentrate from chesse whey. Journal of Dairy Science, Champaign, v. 87, p. 831-840, 2004.

VENTURINI FILHO, W. G. Bebidas Lácteas in Bebidas Não Alcoólicas - Ciência e Tecnologia (PENNA, A. L. B.). Editora Blücher. Vol. 2, Capítulo 6, São Paulo (SP), 2010.

VILLAMIEL, M.; SCHUTYSER, M. A. I.; JONG, P. Novel Methods of Milk Processing in Milk Processing and Quality Management (TAMIME, A. Y). Wiley-Blackwell, A John Wiley \& Sons, Ltd., Publication Ltd, United Kingdom (UK), 2009.

VISSER, J.; JEURNINK, T. J. M. Fouling of heat exchangers in the dairy industry. Experimental Thermal and Fluid Science. 14; 407-424. 1997.

VISSER, H.; JEURNINK, T. H. J. M.; SCHRAML, J. E.; FRYER, P. J.; DELPLACE, F. Fouling of heat treatment equipment. Bulletin of the International Dairy Federation 328, 7-31, 1977.

VISSERS, M. M. M.; TE GIFFEL, M. C.; DRIEHUIS, F.; DE JONG, P.; LANKVELD, J. M. G. Predictive modeling of Bacillus cereus spores in farm tank milk during grazing and housing periods. Journal of Dairy Science, 90, 281-292, 2007.

WALSTRA, P. On the Stability of Casein Micelles. Journal of Dairy Science. Vol 73, Issue 8, Pages 1965-1979, August 1990.

WALSTRA, P.; R. JENNESS. Dairy chemistry and physics. John Wiley, New York (USA), 1984. WALSTRA, P.; GEURTS, T. J.; NOOMEN, A., JELLEMA, A.; VAN BOEKEL, M. A. J. S. Dairy Technology: Principles of Milk Properties and Processes, Marcel Dekker: New York, 1999.

WALDNER, D.N.; STOKES, S. R.; JORDAN, E. R.; LOOPER, M. L. Oklahoma Cooperative Extension Service. Managing milk composition: normal sources of variation. Oklahoma State University, USA, 2014. Disponível em: http://www.dairyweb.ca/Resources/USWebDocs/MilkComposition5.pdf._Acessado em 05/05/2016.

WANG, L; SUNDÉN, B.; MANGLIK, R. M. Plate Heat Exchangers: Design, Applications and Performance. WIT Press, Southampton, UK, 2007.

WEISS, D.; HILGER, M.; MEYER, H. H. D.; BRUCKMAIER, R. M. Variable milking intervals and milk composition. Milchwissenschaft, v.57, n.5, p. 246-249, 2002. 
WONG, D. W. S.; CARMIRAND, W. M.; PAVLAT, A. E. Structures and functionalities of milk proteins. Crit. Rev. Food. Sci. Nutr. 36(8):807-844, 1996.

YOON, J.; LUND, D. B. Magnetic treatment of milk and surface treatment of plate heat exchangers: effect on milk fouling. J Food Sci 59(5):964-9, 980, 1994.

YOUCEF, M.; ABDELKADER, M.; LOUNES, O. A dynamic model for milk fouling in a plate heat exchanger. Applied mathematical modelling, v. 33, n. 2, p. 648-662, 2009.

ZHANG, G.; LI, G.; LI, W.; ZHANG, Z.; LENG, X.; TIAN, M. Particulate fouling and composite fouling assessment in corrugated plate heat exchangers. International Journal of Heat and Mass Transfer, 60, 263-273, 2013.

ZHENHUA, J.; GITAE, P.; YONGHUN, L.; SOONHO, C.; HANSHIK, C.; HYOMIN, J. Design and Performance of Pressure Drop and Flow Distribution to the Channel in Plate Heat Exchanger. In: EngOpt 2008 - International Conference on Engineering Optimization, Rio de Janeiro. 2008. 